Florida International University FIU Digital Commons

FIU Electronic Theses and Dissertations

University Graduate School

2-10-2017

\title{
Worlds Ahead?: On the Dialectics of Cosmopolitanism and Postcapitalism
}

Bryant William Sculos

Florida International University, bscul005@fiu.edu

DOI: $10.25148 /$ etd.FIDC001778

Follow this and additional works at: https:// digitalcommons.fiu.edu/etd

Part of the Continental Philosophy Commons, Ethics and Political Philosophy Commons, International Relations Commons, Political Economy Commons, Political Theory Commons, $\underline{\text { Social }}$ Psychology Commons, and the Theory and Philosophy Commons

\section{Recommended Citation}

Sculos, Bryant William, "Worlds Ahead?: On the Dialectics of Cosmopolitanism and Postcapitalism" (2017). FIU Electronic Theses and Dissertations. 3195.

https://digitalcommons.fiu.edu/etd/3195

This work is brought to you for free and open access by the University Graduate School at FIU Digital Commons. It has been accepted for inclusion in FIU Electronic Theses and Dissertations by an authorized administrator of FIU Digital Commons. For more information, please contact dcc@fiu.edu. 


\section{FLORIDA INTERNATIONAL UNIVERSITY}

Miami, Florida

\section{WORLDS AHEAD?: ON THE DIALECTICS OF COSMOPOLITANISM AND POSTCAPITALISM}

A dissertation submitted in partial fulfillment of

the requirements for the degree of

DOCTOR OF PHILOSOPHY

in

POLITICAL SCIENCE

by

Bryant William Sculos

2017 
To: Dean John F Stack, Jr.

Steven J. Green School of International and Public Affairs

This dissertation, written by Bryant William Sculos, and entitled Worlds Ahead?: On the Dialectics of Cosmopolitanism and Postcapitalism, having been approved in respect to style and intellectual content, is referred to you for judgment.

We have read this dissertation and recommend that it be approved.

Sean Noah Walsh

Richard Beardsworth

Ronald W. Cox

Harry Gould

Paul Warren

Clement Fatovic, Major Professor

Date of Defense: February 10, 2017

The dissertation of Bryant William Sculos is approved.

Dean John F. Stack Jr. Steven J. Green School of International and Public Affairs

Andrés G. Gil

Vice President for Research and Economic Development and Dean of the University Graduate School

Florida International University, 2017 
(C) Copyright 2017 by Bryant William Sculos

All rights reserved. 


\section{DEDICATION}

To my brother Matthew (1993-2010), who isn't here to read this and probably wouldn't have even if he were. He would have loved that I wrote this though. 


\section{ACKNOWLEDGMENTS}

The greatest mythology that was shattered for me in the process of writing this dissertation was not the naturalness of capitalism, nor its general existence as a force for freedom and equality in the world, but instead it was that writing is a solitary activity. Don't get me wrong, the former are undoubtedly myths that are decidedly untrue and explored in detail in this project, but despite the fact that our society places the responsibility, reward, and consequences of writing on the names that end up on the author line of an article, essay, book, or dissertation, writing — at least good writing — can never be a solitary act. There are political reasons for why good writing should not be a solitary act, but in this case, in my case, I mean this more simplistically: I could not have and did not write this dissertation myself. Don't get me wrong, with the exception of quoted and cited material, the words and ideas presented herein are all mine in the technical sense, but I could not have and did not come up with them in the solitude of my own mind. The arguments, ideas, and even phrasing used in this dissertation were the result of intense, often late-night, engagements with some of the greatest thinkers, known and unknown, to have written over the past several centuries - some of whom are still writing today-an even smaller fraction of whom I've had the pleasure of meeting. Their texts challenged, inspired, befuddled, and even often angered me. I love them for it.

My dissertation committee deserves special mention here. Without their support, advice, and strong criticisms, this project would not have come out half as readable and original as it did (however readable and original it did come out is up for the reader to decide, but it surely would have been a lot less so without my committee's input). Paul Warren challenged me to look deeper in my analysis of both the Rawlsian tradition and 
contemporary Marxism. Harry Gould was always there with a poignant question, suggestion, or words of support and solidarity — without which the long dissertation writing process would have been intolerable. Ron Cox was never absent in his demand that I take workers and class more seriously. He also never made me feel like I had to accept his argument in order for him to think I was making a good one myself. I have taken the working class more seriously than I probably otherwise would have (though likely still not as much as he would like), and my dissertation is stronger for his comments, suggestions, and support. Ron also deserves mention for providing me the great opportunity to write for his journal Class, Race and Corporate Power, where I was able to explore my thoughts, beliefs, and hone my craft of writing in a safe, supportive, and collaborative space. Richard Beardsworth left FIU while I was just beginning to work on this project, but he has remained a committed and supportive committee member and contributed a great deal to the development of my argument here-even when I criticized his work and took our shared belief in the value of the cosmopolitan tradition in a different direction. The remaining two committee members deserve more than a mere acknowledgment, but for now, it will have to suffice. The first is my now long-time (not really, but it seems that way) co-author and even-longer term mentor and friend, Sean Walsh. Since my first year in graduate school, as his teaching assistant, learning from and with him has always been my uncredited fourth course, and it was always my favorite. Working with him as a TA and as a co-author, I could not consider myself more fortunate than to have had the opportunity to grow as a scholar and teacher under him. I look forward to years more of collaboration and friendship, provided both of us can manage to eat a healthy enough diet at some point before it's too late! Last but hardly least, is Clem Fatovic, my irreplaceable 
committee chair. I know in many ways this project challenged him, and despite his deep humility for which he is rightly respected and appreciated, his breadth of knowledge of political theory and ability to provide the right advice at the right time- - no matter how unpleasant it may have been to hear or read at the time-allowed me to produce a project that I know we are both proud of. I am in debt to him for not only making me a stronger theorist and more sophisticated thinker, but most importantly, for challenging me to write so other people could understand what the hell I was arguing. He has never been shy about challenging me to (not) abandon certain ideas, nor has he ever been short on supportive words when I needed them most.

Though not an official member of my dissertation committee, I would be remiss if I did not thank the great Brent Steele for everything he has done for me, from reading and providing comments on various early draft chapters of this project to scolding me for buying my own beer while introducing me to a number of other great people and scholars. He also once referred to something I wrote as too Darth Vader-esque. I had only the vaguest idea what he meant, but as a die-hard Star Wars fan, it remains the best comment I've ever received. Brent is simply the nicest, humblest, most praiseworthy person I've come across in academia (maybe anywhere). He will long be the standard for how I measure a senior (and let's admit this Brent, you're getting quite senior...) scholar with respect to how they treat junior scholars and graduate students. Tony Lang and Chris Brown also provided me with excellent feedback and extremely helpful personal and professional advice at various stages during several academic conferences.

A heartfelt thanks is owed to the late Prof. Rebecca Salokar who died just days before I sent the final draft of this project to my committee. She was the department chair 
for Politics and International Relations throughout my time in graduate school, and she strived to cultivate an inclusive and collaborative intellectual environment for all of us, and was always one of my strongest supporters. She also gave me the best teaching advice I ever got. In my first semester of graduate school, in our pedagogy seminar she said: "You're a political theory nerd, but like a funny and cool kind of nerd; let your students see that you love what you do and maybe some of them will let themselves love it too." Though she wasn't part of my everyday, many things she taught me, like this, are - and these are things that can never be missed.

While all of these professors put me in a position to succeed, their efforts would have been for naught if it weren't for the important influence two of my high school teachers had on my life. Donald Franke and Jeff Stanford supported me through tough times, gave me opportunities to lose myself in my studies, and inspired my interest in politics and international relations. To them and for them, I am endlessly thankful.

More personally, I could not have completed this project without the inspiration that comes from great conversations with and the support of colleagues and close friends. Though I could not recall them all, some of my most valued and consistent interlocutors include: Joaquin Pedroso, Mike Wartenbe, Claire Brault, Rudy Leal-McCormack, Lucas Miranda, Garrett Pierman, Linea Cutter, Leo Collado, Alex Torres, Nico Terradas, Ahmad Mirtaheri, T.J. Ligouri, Yonas Mulat, Craig Lang, Mark Mayo, Andrew Lassiter, and Paul Kloster.

Maylin Hernandez listened to me talk about various elements of this project (and many others along the way!) more than any human being could have possibly been 
expected to, and she did so mostly without complaint. Her grace, support, criticism, and especially her skillful close-reading and copy-editing, will forever be appreciated.

Lastly, I want to thank my family: my hard-working older brother Straty with whom I could not be more different and yet similar in so many respects, my dad Robert who has never been anything less than encouraging, my grandparents Dottie and Bill who have always keep me up-to-date on the latest technological developments and trends and supported me in every way they could, my half-brother Nick who has basically grown into a real person while I've been writing this, my exceptionally strong-willed and creative sister Cate, and especially my mom. More than anyone else (could bear to), she listened to me explain my various arguments in excruciating detail and never had to feign interest or support once (or so it seemed). Her love and support carried me to this point. 


\section{ABSTRACT OF THE DISSERTATION \\ WORDLS AHEAD?: ON THE DIALECTICS OF COSMOPOLITANISM AND \\ POSTCAPITALISM}

by

Bryant William Sculos

Florida International University, 2017

Miami, Florida

Professor Clement Fatovic, Major Professor

This dissertation argues that the major theories of global justice (specifically within the cosmopolitan tradition) have missed an important aspect of capitalism in their attempts to deal with the most pernicious effects of the global economic system. This is not merely a left critique of cosmopolitanism (though it is certainly that as well), but its fundamental contribution is that it applies the insights of Frankfurt School Critical Theorist Theodor Adorno's negative dialectics to offer an internal critique of cosmopolitanism. As it stands, much of the global justice and cosmopolitanism literature takes global capitalism as an unsurpassable and a foundationally unproblematic system, often ignoring completely the relationship between the psycho-socially conditioned ideological aspects of capitalism and the horizon of achievable politics and social development. Using the philosophies and social theories of Adorno and Erich Fromm, I argue that there is a crucial psycho-social dimension to capitalism, or capitalistic mentality-represented in and functionally reproduced by transnational capitalism - that undermines the political aspirations of normative theories of cosmopolitanism, on their own terms. 
The project concludes with an exploration of Marxist, neo-Marxist, and postMarxist theories as a potential source of alternatives to address the flaws within cosmopolitanism with respect to its general acceptance and under-theorizing of capitalism. The conclusion reached here is that even these radical approaches fail to take into account the near-pervasive influence of capitalism on the minds of radicals and activists working for progressive change or simply reject the potentials contained in existing avenues for global political and economic change (something which the cosmopolitan theories explored in earlier chapters do not do). Based again on the work of Adorno and Fromm, this dissertation argues that the best path forward, practically and theoretically, is by engaging cosmopolitanism and neo-/post-Marxism productively around this concept of the capitalistic mentality, building towards a praxeological theory of postcapitalist cosmopolitanism framed by a negative dialectical resuscitation of the concepts of class struggle and unlimited democracy. This postcapitalist cosmopolitanism emphasizes nonexploitative economic and political relations, cooperation, compassion, sustainability, and a participatory-democratic civic culture. 


\section{TABLE OF CONTENTS}

CHAPTER

PAGE

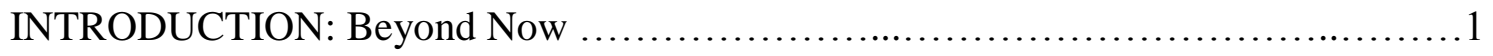

CHAPTER 1: Assuming the Status Quo: Cosmopolitanism Takes on Capitalism..........46

CHAPTER 2: The Capitalistic Mentality: Social Psychology between Base and Superstructure ............................................................91

CHAPTER 3: Cosmopolitanism and the Dialectical Intervention of the Capitalistic

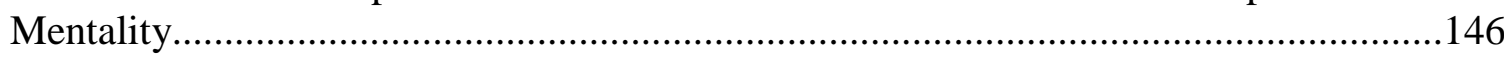

CHAPTER 4: Cosmopolitanism and Socialist Strategy:

Class Struggle, Radical Reform, and Postcapitalism ......................................198

CONCLUSION: Towards a Postcapitalistic Mentality...........................264

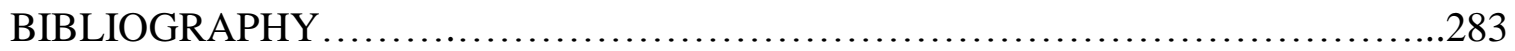






\section{INTRODUCTION \\ Beyond Now}

\section{Introduction}

The core argument of this dissertation is that cosmopolitanism, the most prominent set of theories of global justice, holds a contradictory relationship with capitalism, specifically with regard to the psycho-social dimensions of capitalism. More specifically, this dissertation shows that there are important and under-appreciated intellectual resources in the first-generation of Frankfurt School thinkers, particularly the negative dialectics of Theodor Adorno and the psychoanalytic political theories of Erich Fromm, which can be combined to address a substantial aporia within the theoretical tradition of cosmopolitanism. These untapped resources point to a fundamental and largely ignored problem in contemporary Frankfurt School Critical Theory, particularly the work of Jürgen Habermas and the variety of thinkers working in his legacy, specifically Seyla Benhabib and Andrew Linklater. All of these thinkers broadly comprise what I consider to be a kind of "critical" cosmopolitanism. ${ }^{1}$ In putting Adorno and Fromm in conversation with these contemporary critical cosmopolitans, and cosmopolitan theory in general, we see how the fundamentals of capitalism represent a self-defeating blind spot throughout this important literature-as well as the policies and programs that are pursued with this intellectual tradition as motivation (e.g., large parts of the international human rights regime). This blind spot speaks crucially to critical and more radical cosmopolitanisms' failures in producing significant practical political results.

\footnotetext{
${ }^{1}$ Critical cosmopolitanism here is used in a slightly broader way than how it is used by Gerard Delanty (2008; 2012), who originally coined the term. Delanty uses this label to describe a unique kind of cosmopolitanism that is dialogical and critical of forms of domination, both on a global scale. I am using this label to refer to all cosmopolitans who are basing their theories on Habermas or explicitly self-label their approaches as being part of the wider tradition of critical theory.
} 
This project will approach cosmopolitanism from a perspective distinct from much, if not all, of the recent cosmopolitan scholarship. The typical debates have centered around a few different specific dichotomies: ethical versus political cosmopolitanism, communitarianism/particularism/statism versus cosmopolitanism/cosmopolitics, cosmopolitanism's relationship to liberal capitalism/globalization, and then there are internal debates within each camp that focus on questions of institutional arrangements (practicality, feasibility, likelihood, etc.) as well as the proper path towards the suggested arrangements (usually in relation to extant structures and institutions. Treatments of cosmopolitanism often engage with more than one of the different dimensions or add in additional dimensions depending on the specifics of the particular argument.

I undertake a critical analysis of the lack of a deep engagement with global capitalism in relation to the ethical, political, and institutional facets of cosmopolitan theories. Many might respond by referring to the huge diversity of cosmopolitans who write about the inequity of the global economic order and the appropriate response thereunto in regard to distributive justice. Though I will summarize the core aspects of the major positions on global distributive justice in the context of contemporary capitalism, this will be a tangential moment in my treatment of capitalism in relation to cosmopolitanism here. The problem I will be focusing on is not poverty or inequality per se, though I wholeheartedly support the efforts to alleviate both. Rather, I will be focusing on the relationship between capitalism and cosmopolitanism with regard to how capitalism undermines our collective ability to make progress on issues of injustice within a cosmopolitan framework. 
The chapters of this dissertation develop the intersections and affinities between Frommian and Adornoian Critical Theory (specifically their critiques of capitalist society), arguments regarding globalization, and cosmopolitan-global justice. Integrating these divergent approaches will allow a theoretical hybrid to emerge that can speak directly to theories of postcapitalism associated with the broad post-Marxist socialist tradition. If one of the central claims of most, if not all, cosmopolitan theories is that there should be new forms of political organization beyond the nation-state, this dissertation will explore how global capitalism inhibits this possibility or conditions it so that the cosmopolitan political system that emerges is only marginally more just, if more just at all.

\section{Thinking the World Anew in Political Theory}

Cosmopolitanism as political theory fits neatly into this tradition of specifying an idea of a better future and the struggle to specify the conditions for its possible achievement. For cosmopolitanism, broadly conceived, this mean articulating ethical, political, economic, and institutional arguments that move normative IR theory and the global public policy agenda more broadly towards a more globally just world. This is precisely its paradoxical failure. In its attempts to be at once theoretical, political, and ethical, cosmopolitanism has failed because it has yet to accurately understand the most problematic roadblocks to its own achievement. It has failed to grasp the insights of theorists like Plato, Rousseau, and J. S. Mill: once people are socially conditioned, that is once they internalize the social expectations, they are very difficult to change (Fromm 1994; Verhaeghe 2014). People are psychologically stubborn in complex and varied ways but almost always stubborn nonetheless - even if they are not outwardly or noticeably 
stubborn in their everyday lives (Fromm 1947). Put more simply in other words, social conditioning is stubborn. However, this is not to suggest in any way that people are not changeable. They are, and this social conditioning mixed with the utopian potential for social and self-change are supported by the work of Adorno and even more so by Fromm.

The idea of achieving a new, more just political society while grappling with the destructive or unjust remnants of the old society is hardly a new problem in the tradition of political theory. Plato's Republic is an argument for idealized communism embodying perfect justice. However, one of the main problems that Plato has to deal with in the development of the ideal society is how to convince the already living people to change their ways from their previous ways of living and being in the world in relation to one another and society. That is to say, he has to deal with the question of how to move successfully from the non-ideal society to the ideal society (assuming the ideal society is actually possible). Plato's answer is the combination of the noble lie/myth of the metals, and the removal from society of everyone over the age of ten. Although we may find his solution problematic (as he in fact does as well), the insight it offers will be central to this project.

Rousseau's Social Contract attempts to address the very same problem: how do we get to a free and legitimate political system based on his ideal of the sovereignty of the general will? Rousseau understood as Plato did that people will not change merely because you make a rational argument about the specificity of your ideal conception of legitimacy and a just society. Rousseau opts to argue in favor of the Law-Giver or Legislator. This is a messianic figure (like Moses or Muhammad-Rousseau's examples) who motivates the population to support and internalize specific notions of freedom, justice, and the ideal 
social life. For Rousseau this figure is a necessary precursor to a legitimately governed society. Modern society is a kind of illness that takes a historically renowned figure to "cure."

John Stuart Mill's approach to this question is more specifically related to how to institute a politically and socially liberal system (this is also where Mill garners a lot of accusations of imperialistic and colonialist sympathy-some perhaps more justified than others). Mill argues that his principles of and arguments for liberalism are appropriate for already civilized peoples but do not apply to the barbarous or uncivilized. Until people are civilized, they cannot properly embody or achieve a liberal value system (which he perceived to be a universal desire).

There are more salient arguments for progress and radical transition that are more relevant to the cosmopolitan and critical theoretical traditions and will be mentioned later in this project, such as Kant's and Marx's. What these central figures in the philosophical foundations of cosmopolitanism and Critical Theory fail to do is address though is the question of psychology or virtue with regard to the next progressive stage of society and specifically how the psychology or virtue in the current stage threatens, undermines, or prevents the emergence of that next progressive stage or they do so in superficial or historically untenable way. Much of contemporary cosmopolitan theory and even the common communitarian critiques have failed to address this aporia as well. ${ }^{2}$ The kind of thinking, dispositions towards the world and others, and individual character traits that are encouraged under capitalism are antithetical to the kind of virtue needed to cultivate global solidarity, ubiquitous support for substantial international human rights and even hinder

\footnotetext{
${ }^{2}$ E.g., Michael Sandel (1998) and Charles Taylor (1989; 1991)
} 
the emergence of globalizable democratic socialism (which will be argued is the only reasonable response to the ethical demands of cosmopolitanism).

The psychological failure of cosmopolitanism is not nearly as straightforward as communitarian statists ${ }^{3}$ often suggest or even the more philosophical argument of Richard Rorty claims. ${ }^{4}$ For thinkers like Sandel (1998) and Taylor (1989; 1991) among others, liberal universalism (which normative cosmopolitanism is typically, and for good reasons, treated as) misunderstand the nature of human identity and how it is that people become who they are, and thus how they form moral ties to others. While I do not plan to delve into this question, the communitarians have a point on the formation of identity but commit a naturalistic fallacy in extending the empirical formation of the self and identity to the realm of moral obligation (which is the standard cosmopolitan response from the thinkers addressed in this project). Additionally, human nature (though someone like Rorty, who more or less make that it is), avoids this terminology) is not the problem. The existing institutionalized power structures are not really the key problem (except in the psychological sense that people perceive them to be impossible or very difficult to reform or radically change).

The problem, I argue, is a horrible combination of ideology, instrumental rationality, identitarian thinking, and the marketing social character, and specifically how these interrelated aspects of (late/consumer) capitalism combine to create a globallyexpansive and deepening social-psychological phenomenon that I refer to as the “capitalistic mentality." It is precisely this capitalistic mentality that has stalled and will

\footnotetext{
${ }^{3}$ E.g. Michael Walzer (1977; 2000), David Miller (1995; 2000), or Mervyn Frost (1996)

${ }^{4}$ See Rorty's argument summarized in "Who are We: Moral Universalism and Economic Triage" (1996) and Philosophy and Social Hope (1999)
} 
continue to stall the development of the psycho-political normative ethos necessary for the further development of an emancipatory cosmopolitan world order. As the above (extremely brief) survey of cosmopolitanism shows, there are few references made to the actual fundamentals of the system of capitalism understood as an exploitative, alienating economic system or more accurately and broadly as a totalizing economic system that is continually expanding as a social, political, and cultural system as well.

\section{Cosmopolitanisms and Responses to Globalization}

The various cosmopolitan thinkers address the topic of global justice and political community in unique ways. Despite these difference there are some shared characteristics that make cosmopolitanism a loosely cohesive political-theoretical tradition which reaches back to the ancient Cynics and Stoics. All of the versions of cosmopolitanism addressed here though, in part or in whole, derive more closely from Kant's essays "Perpetual Peace" and "Universal History with a Cosmopolitan Purpose." The most central shared characteristic of all cosmopolitanism is that membership in the community of humanity is more morally relevant than membership in any smaller form of community, including but not limited to the nation-state, ethnic group or religious association. This principle can be stated more strongly as many cosmopolitan theorists do, that nation-state boundaries are

morally irrelevant. The second shared principle of cosmopolitanism, which derives from the first, is that because political or cultural boundaries are morally irrelevant to determining the moral or political worth of a person or group of people, all people must be regarded as morally equal to one another. Thus, the third principle is that our obligations and responsibilities to one another cannot ignore or privilege a preferred group or 
community due to those morally irrelevant boundaries. In other words, the third shared principle is that we have an equal obligation to others regardless of where they live or where they were born or regardless of any other morally insignificant distinction (including those established by historically contingent lines on a map). Among the more political conceptions of cosmopolitanism, there is a fourth shared principle that advocates for a transnational political structure that embodies or at least furthers the normative goals held by the more philosophical-moral cosmopolitans. ${ }^{5}$

What follows is a treatment of cosmopolitanism generally and washes over a number of important distinctions among and between cosmopolitans - for the purpose of highlighting a shared flaw in the tradition as a whole. For the sake of clarity I will discuss several of the major cosmopolitan thinkers relevant to rest of this project, while fully noting that the exclusion of any particular thinker is a result of academic expediency not necessarily theoretical substance.

First we have the liberal, "post-Rawlsian" cosmopolitanism of Charles Beitz, Thomas Pogge, and David Held. Next, we have the cosmopolitans working in the tradition of Jürgen Habermas and communicative action and discourse ethics represented by Andrew Linklater and Seyla Benhabib. Third, we have the more radical cosmopolitanisms of James Ingram and Pheng Cheah, who builds on the social-democratic theories of Held and the Habermasian approaches, with the addition of post-structural, radical democratic elements.

The key arguments made by the liberal cosmopolitans Beitz (1979), Pogge (2008), and Held $(1995 ; 2004)$ are as follows. First, the contemporary nation-state is ill suited to

\footnotetext{
${ }^{5}$ Most books that engage with cosmopolitanism contain similar summaries including Beardsworth (2011), Delanty (2008), Van Hooft (2009), and Holton (2009)
} 
properly respond to the dynamics of recent globalization and thus there is no longer a pragmatic justification for such a state-centric global political order, because states are no longer the best-suited or most efficient political community possible to solve the problems that people face in their lives. Secondly, reflecting this loss of appropriateness, international politics needs to be democratized across the board. This means reforming existing institutions and creating new ones that are appropriately democratic and dispel the dominance of national sovereignty. The third point is that the global economy results in harmful inequalities that are unnecessary and unjustifiable. Because those of us in the West benefit from this system, we are duty-bound to redress the harms it has caused and continues to cause. The result of this third point is a call for some kind of global redistribution of wealth and resources. Pogge's idea of the "global resource dividend" is one of the most clearly articulated versions of this third aspect.

Sharing many similarities with this first group of thinkers are the Habermasians. Linklater and Benhabib have attempted to utilize the insights of Jürgen Habermas' theory of communicative action and discourse ethics to articulate practical, normative theories of critical-theoretical cosmopolitanism. Though in different ways, they both argue that globalization brings more people into contact and association with groups of people from other cultures and communities whom they would have never had interaction with before. This interaction leads to the potential for the universalization of domination-free, cooperative communicative action and thus the potential for transnationalized public will formation and democratic iterations that transcend the traditional boundaries of communities, specifically nation-states. This dissertation will show how Habermas' notions of strategic versus communicative action support my thesis-though not as 
Habermas uses them-when we look at capitalism as embodied in the capitalistic mentality. Put simply now, the logic of capitalism inherently undermines the possibility of sustainable communicative action on a mass scale.

Responding to and building on many of the critiques that Habermas' work has garnered from postmodernists and post-Marxists, even extending to those utilizing his theories, James Ingram recently published a novel contribution to cosmopolitan theory. His Radical Cosmopolitics (2013) offers a re-politicized Left critique of the more liberal, topdown, and institutional approaches to cosmopolitanism. His "radical" cosmopolitanism, understood as simultaneously ethical and political (as opposed to treating the ethics and politics separately, which Ingram accuses most other cosmopolitans of doing), argues that politics is the ethical goal of cosmopolitics, specifically the drive for more universalized democratization worldwide across all levels of political institutions and political activity. For Ingram, the struggle for global justice and human rights must be understood as both the means and the end. Being able to participate in these struggles for democratization is the goal, as it the successful conclusion of those struggles (though borrowing insights from the agonistic pluralists he believes that the struggle will always continue in some form or another, but taking the middle ground makes a progressive improvement argument as opposed to final, successful conclusion-as more moderate take on the supposedly postMarxist agonism of Laclau and Mouffe [1985]). The key for Ingram is to understand cosmopolitanism as a site for specifically political struggle (which includes struggles over economics and culture-politics is the site of that struggle). Although he does discuss the evils of poverty, inequality, and economic crisis, there is a lack of serious engagement with capitalism as a system throughout his argument. Even the most "radical" cosmopolitanism 
to date fails to be truly radical because it does not go to the root of the problem: the negative dialectic within cosmopolitanism, the psychological disposition fostered under capitalism. Cosmopolitan progress requires the demystification and redress of the capitalistic mentality.

In order to understand and appreciate the novelty of this project, a more solid grounding in the distinction between contemporary cosmopolitanism and Marxism is an order. It is well known that much cosmopolitan theory is regarded as being more or less liberal, in either its ethical or political varieties. ${ }^{6}$ That being said, Chris Brown's (1992) work in the subfield of international political theory articulated a version of cosmopolitanism that was broad enough to include Marxism understood as supranational socialism. Though Brown's articulation of Marxism as a kind of cosmopolitanism is restricted to the predictions and normative goals of Marxism (the dictatorship of the proletariat and then a classless, stateless society), he does allow for the characterization of Marxism as a class-based theory as opposed to possessing the individualistic quality of cosmopolitanism. Brown was one of the original thinkers to contextualize Marxism within the broader theoretical tradition of cosmopolitanism, but he is not alone even if the neoKantian liberal cosmopolitanism (including the so-called "social-democratic" cosmopolitanisms of Held and the various Habermasians) is still dominant. The recent scholarship of Richard Beardsworth (2011) has further normalized this vision of cosmopolitanism and Marxism as distinct theoretical and normative traditions that are best understood separately. Though in his characterization of these different groups of thinkers

\footnotetext{
${ }^{6}$ See Beardsworth (2011).
} 
the separation makes sense for both disciplinary and pragmatic reasons, the philosophical and ethical costs are too high to hypostatize this separation.

In his Cosmopolitanism and International Relations Theory (2011) Beardsworth provides separate chapters summarizing the "Marxist critique of cosmopolitanism" and the "Cosmopolitan response to Marxism," respectively. It is in these two chapters that the problematic normative-theoretical separation between these two traditions is reified and mystified. The cosmopolitan response to re-embed liberalism (borrowing from David Held and Karl Polanyi among others) within a regulated marketized global social democracy does not make up for the failure to appreciate the interconnectedness of the normative goals of international socialism and cosmopolitanism, nor does it redress the social, cultural, and psychological aspects of capitalist globalization. It is not merely that Marxists argue for the impossibility of separating politics and economics as Beardsworth claims, but that Critical Theorists in the Marxist tradition expand that position to suggest that capitalism comes to dominate all aspects of human life, including psychological disposition, social norms, and cultural practices. ${ }^{7}$

Etienne Balibar $(2012,2013)$ has been one of the key political theorists to reignite the socialist internationalist version of cosmopolitanism, and Pheng Cheah $(2006,2007)$ has also made a serious effort to bring Marx back into the cosmopolitanism conversation. Even liberal and social-democrats like John Dryzek, Held, Habermas, Benhabib, Nancy Fraser, Linklater, and Pogge are all highly critical of the results of capitalism in a fashion

\footnotetext{
${ }^{7}$ It is likely that the organization of the book is more at fault for its failure to highlight the nuanced similarities between many Marxists and cosmopolitans rather than any serious misunderstand on the part of the author. With that said, the book reifies the traditions and makes it difficult to imagine how they could and should be viewed as normative dialectical dance partners as opposed to dueling gangs of enemy theories.
} 
that would have drawn at least measured, skeptical approval from Marx. The Marxist tradition does indeed proffer a vision that rejects the ethical legitimacy of nation-state borders, but it is usually believed that this is only because nation-state borders undermine the emergence of the revolutionary solidarity of the working-class globally. This is only part of the story, however. For Marx states that the condition for the free development of each is the free development of all. As Etienne Balibar (2014) has implied in his theorization of transindividuality, ${ }^{8}$ Marx does give credence to the ethical value of individuals but refuses to reify the individual as entirely distinct from their social relations. What it means to be an individual to Marx is socially constituted. Thus, the individual is not an unencumbered self as many versions of liberalism suggests, but rather a sociallyconditioned, socially-bounded, intersubjective transindividual that is incomprehensible outside of those social parameters. Class position is indeed the central aspect of those social relations, but it is not everything - a point that will be discussed a bit later in this introduction but more fully in chapter four.

The point of this dissertation is not to suggest that we merely need to substitute Marx for Kant and cosmopolitanism will be cured of its liberal capitalist ills. The idea is not that Marxist political economic theories need to be substituted for social-democratic ones (though Marxist economic insights are continually invaluable to the Left progression of reformist social democrats). Rather, it is my contention that by gleaning insights from Marx and much more so from those working out of his tradition that the immanent theoretical and empirical contradictions between cosmopolitan approaches and goals and

\footnotetext{
${ }^{8}$ A label given by Balibar to describe agents in social and political theories, like Marx's, where there is an equal acknowledgement of something like an individual and community; individuality cannot be entirely separated from community and group identities, and is in fact constituted by these non-individual factors, at least partially.
} 
capitalism as a totalizing system become apparent. First-generation Critical Theory offers the dialectical, praxeological diagnosis as well as the opening to a practicable, theoretical solution to the psychological contradictions of global capitalism in relation to the normative vision cosmopolitans seeks. ${ }^{9}$

There have also been some books written for more popular consumption that have addressed the social-psychological aspects of capitalist globalization a bit better than those exclusively writing in/for academia have. The first texts worth mentioning are Ben Barber's Jihad vs. McWorld (1996) and the subsequent publication Consumed (2008). These texts taken together support the thesis that will continue to be developed here in the context of cosmopolitanism: consumption and consumerism spread like diseases and are similarly destructive to the self-same attempts at the betterment of the quality of life for people everywhere. The corollary is that where capitalist globalization spreads, there will be both reactionary and radical resistances to it. The quality of those resistances have been empirically varied but equally limited in their success; globalization continues. Again, taken together we can imagine that Jihad vs. McWorld can be used to tell the story of the globalization of the phenomena described in Consumed; the story is the globalization of rampant conspicuous, competitive consumerism.

In a similar vein, Amy Chua's World on Fire (2003) looks at how economic and political globalization (the intentional spread of democracy and "free" markets worldwide) breeds destruction and resistance primarily because it ends up privileging either previously

\footnotetext{
${ }^{9}$ This project is not about poverty. Cosmopolitanism, specifically in the versions that focus on global redistributive justice like Pogge, Held, and others, already has a great deal of purchase on the problem of global poverty. One need not be a socialist to understand or object to the globalized instantiation and exacerbation of economic inequality and extreme poverty. However, it will be shown here that one in fact does need to be a socialist to articulate a vision that alleviates the foundational roadblocks the emergence of a just, cosmopolitan global order.
} 
culturally dominant minorities, new internal minorities, or most troublesome new culturally external minorities. There are two points that should be drawn from Chua's book that are relevant to this study. First, globalization includes the spread of an oppressive, dominating market-mentality that overtakes previous cultural practices or gets internalized within already-existing cultural practices. The second insight is that this undermines the emergence of cosmopolitan solidarity necessary for the continued development of dialogic communities, feelings of hospitality, shared notions of rights, cross-cultural recognition, and communicative action more broadly.

Lastly, we have Ethan Watters' Crazy Like Us: The Globalization of the American Psyche (2010). Watters, a pre-eminent journalist and essayist, tells his experiences of traveling the world, specifically focusing on how the Americanization of conceptions of and treatments for mental illness has led to the exacerbation of certain behaviors, almost all of which are depicted as being destructive to the specific culture or nation's previous ways of understanding and dealing with the undesirable aspects of the human condition. Many of the stories that Watters tells support the thesis developed in this dissertation that global capitalism spreads and behaves similarly to diseases, especially when it comes to psychological and behavioral norms.

There have only been a couple serious uses of Adorno in international relations in the past decade. Daniel Levine's Recovering International Relations (2013) utilizes Adorno's negative dialectics to construct the idea of the vocation of the Critical International Relations scholar and a non-identitarian constellation-based methodology appropriate to that vocation. Though the normative aspects of Adorno's work are present, they are applied in the narrow sense of IR methodology, not so much in regard to the world 
itself. Conversely, Steven Roach's Critical Theory of International Politics utilizes Adorno's negative dialectics in support of a version of international federalism that is nonreified, but is also far too unspecific and convoluted. It has generally failed to garner the attention of the wider critical IR theory community.

There have been even fewer serious engagements with the political or social psychological thought of Erich Fromm. Lawrence Wilde has been the intellectual most steadfastly attempting to revitalize interest in the forgotten contributions of Erich Fromm, and is the sole theorist to have used Fromm primarily in conversation with cosmopolitanism. ${ }^{10}$ Wilde first presented his cosmopolitan interpretation of Fromm in his 2003 book Erich Fromm and the Quest for Solidarity. He has further expanded on this interpretation within the context of a cosmopolitan interpretation of the radical humanist tradition, of which Fromm is one of the key figures, in Global Solidarity (2013). Wilde argues that Fromm's work is best interpreted as a kind of virtue ethics that shares important similarities with the capabilities approach developed by Martha Nussbaum (2011) and Amartya Sen $(1983 ;$ 2003). Wilde claims that for Fromm people possess core potentials (rationality, compassion, productiveness, and cooperativeness) that are undermined and prevented from being achieved more fully. I agree with Wilde's characterization of Fromm's ideas up to this point. Though as with the cosmopolitan theories discussed above, when it comes to locating the core of the problem in society, Wilde asserts that Fromm

\footnotetext{
${ }^{10}$ There is good reason why Fromm has long been excluded from the tradition of cosmopolitanism. The first reason is that in recent political theory there has been the long-raging dispute between communitarian and liberals (cosmopolitans), and Fromm originally referred to his version of humanist socialism as communitarian socialist. The well-regarded Politics and Vision of Sheldon Wolin (2006) confirmed this characterization using the label communitarian to characterize Fromm. However, as Wilde has explained in detail in two separate books, although Fromm's political vision may rightfully carry the self-ascribed label of communitarian socialism, the normative justification for that political vision is foundationally and pervasively cosmopolitan (universalistic).
} 
would say that poverty and inequality are the primary forces that undermine the achievement of core potentials and thus global solidarity. This impoverished interpretation of Fromm is important but unnecessarily limited. Fromm has so much more to offer political theory and normative international relations theory. In order for Fromm to be at his most useful, we must utilize the full depth of his intellectual legacy. We must understand more fully how the psychological aspects of capitalism, regardless of poverty and income inequality, undermine the core potentials of humanity and thus undermine global solidarity.

\section{Psychological Capitalism and the Capitalistic Mentality}

Much of the perceived credibility of this project will be based on the acceptability of the notion of capitalism that is utilized. Through I will use a working definition of capitalism (merging both Marxian and Weberian components) to show how cosmopolitan theorists misjudge the inherent social and psychological impact of capitalism in all spheres of human life, principally its conditioning of those who are socialized into it towards competitiveness, acquisitiveness, and avarice, as well as its more broadly alienating character.

In order to offer a praxeological critique of cosmopolitanism based on a psychological understanding of capitalism, a widely accepted definition of capitalism is needed lest the phenomena I am describing be attributed to an arbitrary definition of capitalism. Much of the first-generation of Frankfurt School Critical Theorists understood capitalism in a much more complex way than people had previously and even differently than most scholars do today. Capitalism is certainly an economic system, but it is far from 
just an economic system. Capitalism structures the mind of the people who are born into it as well as those that are conquered by it. The definitions used by Marx and Max Weber support this characterization, never mind the more contemporary cultural understandings of capitalism offered by David Riesman (see the Lonely Crowd [1950], which is heavily indebted to Fromm's notion of social character), Daniel Bell (see The Cultural Contradictions of Capitalism [1976]), and Slavoj Žižek (see The Sublime Object of Ideology [1989] etc.).

What is capitalism then beyond the standard interpretation of merely an economic system with certain economic characteristics? Marx's view of capitalism focuses on the expropriation of surplus value from a class of laborers (the proletariat) by the class who owns the means of production (the bourgeoisie) through the payment of a wage that undercompensates and thus misrepresents the actual labor time put in compared to the value received by the employer. The value of the goods being produced is based on an unstable, market-determined combination of both use-value and exchange-value, with exchange-value being the primary determinant. This leads to what Marx calls commodity fetishism which is a mystified social value added to goods that is unconnected to the amount of labor put into producing it, the raw materials it is made out of, or from its usevalue (Marx, Capital Vol. 1). ${ }^{11}$ The idea here is that as a commodity, the value of a thing becomes embedded in perverted social relations that exceed any economic determination beyond the technology needed to produce it, which the value ascribed to a commodity so often does exceed. The reasons this occurs are based on the psycho-social mystification and alienation of the production process itself (Capital Vol. 1, 320-321).

${ }^{11}$ All citations to Marx come from Robert C. Tucker's The Marx-Engels Reader $2^{\text {nd }}$ edition (1978). 
Weber's definition of capitalism on the other hand is connected to his sociological theory of the Protestant ethic, and focused on the drive for accumulation of profit. The accumulation of profit becomes its own end according to this view. This is not to say that under capitalism accumulation of profit for profit's sake is the only acceptable goal for accumulating wealth, but the supposition is that when the accumulation of profit comes into conflict with other ends, in most cases, in the last instance, the accumulation of profit emerges as the superior goal (again, generally speaking) (Weber 2009; Giddens 2010 [1971). For both conceptions of capitalism, the economic interactions that seem to exhibit non-capitalist characteristics (such as charitable donations, or unremunerated household labor) are either the exceptions that justify the core characterization, or in some way support the core aspects of capitalism. For example, an unpaid housewife buys many things in order to complete her household tasks. Even though she is not subjected to an expropriation of surplus value in the form of an hourly wage (although her labor surely supports the possibility of an overall capitalist economy), her labor includes numerous supportive interactions with the greater capitalist system. With that said, the definition of capitalism for my purposes is: a system that aims at the endless accumulation of capital as its own end, through the expropriation of surplus-value in the form of wage-labor (Wallerstein [1983] 2011; Robinson 2004).

Now even this synthetic view seems to describe capitalism as purely an economic system. In reality, the definitional aspects of capitalism, although wholly economic in nature, inherently affect all aspects of society and social relations (including politics, the family, culture, religion, art, etc.). This point is absolutely central to my critical reinterpretation of cosmopolitanism. Capitalism, although definitionally an economic 
system, the specific nature of its economic character expose capitalism as a totalizing social system. ${ }^{12}$ Until contemporary cosmopolitans even those "critical" cosmopolitan theorists understand the incompatibility of capitalism with each of their conceptions of justice, justice will remain elusive.

The primary aspect of capitalism that undermines cosmopolitanism is rooted in the concept of alienation. As a philosophical-social concept it emerged in the thought of G.W.F. Hegel and was drastically elaborated upon by Marx in his early writings, most notably in the Economic and Philosophic Manuscripts of 1844 (also known as the Paris Manuscripts). In Marx's later work, alienation is still an important theoretical concern, but it is subsumed into the concepts of exploitation and commodity fetishism (Tucker 1978 [1972]). Alienation is typically viewed as a concern of so-called humanist Marxists, and although this is fundamentally accurate, alienation as described by those humanists is a structural aspect of capitalism. It is the product of an economic system based on the private ownership of the means of production. For Marx, we are alienated from the process of our labor (we rarely work on more than a piece of the product or service even); from the product of our labor (in that we do not own it); from our species-being (our "human nature"); from ourselves (we begin to see ourselves as inhuman or machinelike; we feel and think less and end up acting robotically); from each other (we regard each other as competitors in the marketplace of consumer goods or labor opportunities or as a means to improve our own lot in life, not in solidarity as a fellow human); and finally from nature (we are separate

\footnotetext{
${ }^{12}$ By totalizing, I do not mean to say that in $100 \%$ of social interactions capitalism is evident. By totalizing, I mean to say that it is generally constantly expanding and always influences non-economic aspects of society, and the primary mechanism of this influence is psychological conditioning.
} 
from nature; it is "out there," and it exists to provide us with material resources to consume)(Ollman 1971; Marx 1978).

Why this facet of capitalism became so important to the humanist vein of Marxist interpretation is because it organically alters the subjects of capitalism's ability to achieve solidarity with one another, thus preemptively aborting progress toward socialist revolutionary change (Fromm 1994 [1941]; 1976). Alienation as understood by Marx prevents individuals, especially those who are members of the proletariat (those who do not own or control the means of production but merely toil on it to survive with the ensuing surplus-value and profit flowing to the owners of said means of production, the bourgeoisie), from living a fully human and humane existence according to our speciesbeing, defined as "essential life activity" which for humanity means laboring as one freely chooses to. Additionally, because the defining characteristics of capitalism require the exploitation of wage labor and profit-seeking, ideological discourses that legitimize and/or mystify this feature of capitalism, exploitation becomes normatively acceptable, even if not in its most egregious forms (e.g., chattel slavery or 14 hour work days)(Ollman 1971).

Working within and beyond the Marxist tradition, social psychological theorist and socialist humanist Erich Fromm characterizes the problem of alienation in a less rigid manner, building on a Marxian foundation, and comes to an even more radical conclusion: alienation is the fundamental harm produced by capitalism (Fromm 1961; 1976). In order to depict the problem of alienation and move beyond it, Fromm developed his famous conceptualization of social character. Social character is a social psychological category which refers to "the nucleus of the character structure which is shared by most members of the same culture in contradistinction to the individual character in which people 
belonging to the same culture differ from each other" (1976 [1955], 78). The most common social character under capitalism (although it was always present in different behavioral manifestations in previous modes of production) is the marketing character. The marketing social character is an orientation towards life that utilizes a sales mentality. This could characterize economic relations, politics (marketing is a huge aspect of political campaigning, something many people argue is much more important that the qualifications of the candidate with regard to their potential for electoral victory), romantic relationships (we often say "Are you on the market?" meaning "are you single?" or we view potential mates in the same way we look at cars: is it the right color, is it the right size, does it possess the luxuries we value, will it look good next to me, will other people be jealous of me if I possess this, etc.).

In his last major work published before his death, To Have or To Be? (1976), Fromm simplified his variety of social character ideal-types to a kind of social theoretical binary in the context of late capitalism. The more scientific concept of social character, which contains much more nuance and psychological specificity, is transformed into "modes-of-existence" of which there are two: having and being. Most people under capitalism focus on having, not being. Humans become progressively distanced from their humanity towards psycho-social automation (i.e. we are becoming automatons). People are conditioned by new family traditions, the social environment in elementary, secondary, and high schools and even universities, by advertising, and a whole host of other influences into escaping their alienated, internally isolated existence. We attempt to live through our possessions because the smooth functioning of capitalism generally prevents most of us from living through each other in creative and ameliorative ways. For Fromm, a just, sane 
society based on the "having" mode of existence is a negative contradiction. It is an impossibility. Justice, even sanity, requires progress towards the "being" mode of existence; living for and through ourselves and one another instead of for and through commodities and profit-seeking.

Psychology has provided little evidence for the existence of "switches" within the human mind that allow us to consistently turn certain behaviors off and on as we choose. Social conditioning undermines free will and agency at every turn, even if incompletely. The capitalistic mentality, as it is reproduced through capitalist ideology, functions as a psychological phenomenon; it is not merely ideology, and it implicitly and consistentlyif imperfectly-undermines solidarity and non-instrumental cooperation wherever capitalism spreads.

Success under capitalism requires people to be more competitive than they otherwise would be. I am not making the argument that people would not be competitive under alternative modes of production. History has shown us that people were competitive under feudalism and tribal modes of production. It is, however, my supposition, and one first explained by Fromm, that the marketing personality that succeeds in capitalism is far more pervasively competitive than under previous modes of production as well as under certain, potential future ones (Fromm [1941] 1994).

Thus far Adorno's negative dialectics has only been felt implicitly, though a more comprehensive explanation of the intersection between Fromm's notion of paradoxical logic and negative dialectics will be given in chapter two. ${ }^{13}$ Before detailing what negative

\footnotetext{
${ }^{13}$ Negative dialectics as an interpretive approach to political theory is outlined in much greater detail in my chapter in Interpretation in Political Theory (2016), edited by Clement Fatovic and Sean Noah Walsh. Beyond this and Jameson's work on dialectical criticism in Marxism and Form (1974), Gillian Rose ([1978] 2014) also provides support for the possibility of using negative dialectics as a philosophical,
} 
dialectics is more specifically, it is useful to point out how it is already being utilized. Negative dialectics calls attention to contradictions. According to Fredric Jameson (2007), this is the defining characteristic of all dialectical thought, and negative dialectical thought is hardly an exception. By taking a negative dialectical approach, the contradictory presence of both capitalism and an argument for progress within cosmopolitanisms appear as the mutually destructive components they are in reality. Unlike Hegelian or Marxian dialectics, there is no presumed teleology: the positive negation of the negation is not guaranteed from the beginning and without de-reifying agency and demystification it is likely that the negation of the negation will be a negative as well (Adorno 1973; 1993; 2003). This means that we cannot assume the liberal-democratic aspects of capitalism will win out over the exploitative, unequal, plutocratic leanings of capitalism. We cannot assume that progress under capitalism really means progress for most people. We must never forget that a concept like progress is never identical to the reality of "progress," which for Adorno is implicated in process of regression and dehumanization along with the advancements of technology and certain political freedoms (Adorno and Horkheimer [1947] 2007).

To elaborate slightly on this very rough explanation of negative dialectics, the core principle is the rejection of the central characteristic of Western logic, the law of noncontradiction. The law of non-contradiction holds that something cannot be a thing and not that thing at the same time (A cannot be A and non-A at the same time). Contrary to Hegel's argument regarding the dialectic that "the whole is true," Adorno counters axiomatically that "the whole is false" (Buck-Morss 1977). Capitalism is the embodiment of a false material-social world. 
totality, not the pure positive, rational totality that Hegel implies. It is a totality that represents the destructions of humanity among humanity. It is a totality that is at once material and imaginary (or ideological). Adorno argues that there is no reason for us to assume that this is the case, and he offers the non-identical relation between language and reality as the primary example. As I just mentioned, progress is both progress and not progress at the same time. We can see this in the reality of our global situation: not only is progress only progress or more progressive for certain people (usually the already wealthy and privileged) but progress also means the destruction of our biospheres and ecosystems. When we fail to remember that concepts are never identical to themselves (they are never identical to the reality they purport to describe), we are exemplifying "identitarian" thinking and more specifically reifying language and the world. Reification is the practice of making something abstract or ideal concrete when it is not. For Adorno (1973; 2003), reification is part and parcel of identitarian thinking, though it is more harmful because reification involves forgetting the forgetting. Reification means that we believe we understand reality through our concepts; we don't even realize we are engaging in problematic identitarian thinking.

Identitarian thinking is additionally an important aspect of instrumental reason (a concept inaugurated in the sociological theories of Max Weber but expanded by Adorno and Horkheimer). Instrumental reason is the reasoning of capitalism; do not question the end (the end is pre-given and everyone learns it from an early age: make profit/make money) but only the best way to achieve that end. Reason becomes broadly utilitarian towards that particular end. Identitarian thinking is central to instrumental reason because it is economical. It doesn't waste time with the complexities of reality. It doesn't concern 
itself with justice or externalities that they perceive to cost nothing. This is precisely what combines with Fromm's work to develop the amalgamated concept of the capitalistic mentality.

This project, and chapter two specifically, will argue that we are socially conditioned to think that competitiveness, greed, possessiveness, hyper-self-interest, material inequality, and even rampant violence are the dominant aspects of human nature (embodied in the practices of consumerism). We reify human nature by failing to question how competitive or how self-centered people "naturally" are, and we are encouraged to, because this is consistent with the dominant ideology and logic of the profit-motive. There is strong, suggestive sociological evidence of the pervasiveness of these beliefs that will be provided in the dissertation, though one need only turn on Fox News or take a stroll through the conservative blogosphere (including the comments sections) from Redstate.com to Breitbart.com to see how seriously such beliefs are taken by hundreds of thousands, if not millions of people (even though this is admittedly far from a random sampling of the population). The capitalistic mentality is this psycho-social behavioral framework we are conditioned into that promotes the marketing social character, having (over being), a pathological relation to normalcy, pervasive reification and identitarian thinking. Applying a negative dialectical analysis, framed in this way, to cosmopolitanism allows us to demystify precisely why capitalism - understood socially, culturally, and psychologically—undermines cosmopolitan sensibilities.

\section{The Dialectic of Exclusion and Inclusion}


In every era of history there are ideas that are believed to be impossible, and for a lot of those ideas history has thus far been proved right, but for a number of other ideas, history has been proven wrong. The main argument of this project is more about the pragmatic possibility of making drastic improvements towards - the perhaps unreachable ideal of-egalitarian global justice through universal institutional inclusion than proving definitively a singular, particular way to immediately fulfill the promise of universal human rights understood both politically and economically.

I will go on to argue that capitalism is, as an increasingly ubiquitous framework, a kind of active retrovirus that permeates the circulatory system of all levels of socio-political interactions and thus supports and expands this latter kind of diseased politics. Dialectically, however, a potential solution of global solidarity and cosmopolitan spirit is made possible through the ubiquity and global contagiousness of capitalist systems. In its pervasiveness, capitalism allows itself to be the target of revolutionary reform it rightfully should be. This overcoming of the capitalistic mentality is far from guaranteed by the structures of capitalism itself; it is only with a change in the spirit-that is, in the psychology of humanity - that emancipatory justice can overtake the annihilatory leanings of the capitalistic social character (Adorno 1968; Fromm [1960] 2010; 1968). It is not only people that need to change; institutions do as well. The institutional change- because it can affect more change than ad hoc re-education-likely needs to, if only slightly, precede the more pervasive shift in global social character. A change among a minority of people could lead to a change in the institutions of global and national politics as I will lay out, but a more widespread change in character requires more time and would likely be 
undermined without institutional support. ${ }^{14}$ The likelihood of success in regard to any of this is still highly unlikely given the current trend of things. However, as both Adorno and Fromm suggest throughout their oeuvres-with differing and variable degrees of optimism - radical yet reasoned belief in the power of the possibility of success and the need for such success is all that can be guaranteed by taking the capitalistic mentality seriously as the psycho-social threat to global justice and human emancipation.

If much of cosmopolitan theory concerns itself with peoples' universal inclusion in systems of justice beyond and within nation-states, the central dichotomy is thus one of inclusion versus exclusion. However, this dichotomy can only serve the cause of global justice so well before its thus far reified applications countermand its own ends. We must understand the nuances and complexities of inclusion versus exclusion, specifically the quality of the inclusion and exclusion. ${ }^{15}$ What will be expanded on is the quality of the inclusion or exclusion from global capitalism as well as the socio-economic variables that play a part in kinds of political exclusion.

As external observers of and participants in systems of inclusion and exclusion, we can see aspects of the capitalistic mentality at work in something as seemingly purely political as who is included as a citizen. Our media is saturated with rhetoric nowadays testifying to the horrific job-stealing character of illegal immigrants entering the United

\footnotetext{
${ }^{14}$ As we see today, global institutions are preventing radical reforms toward egalitarian, democratic justice even while claiming the opposite. Institutions can have a trickle-down effect on the people they preside over. This mechanism could turn out to be a vital one for the project I am explicating here.

${ }^{15}$ Not all kinds of inclusion are positive, just as not all kinds of exclusions are negative. For example, being included in the institution of slavery was never a good thing, nor was it necessarily great to be a "free" wage laborer working on the Erie Canal during the late years of slavery in the United States (the historical records are rife with anecdotal evidence suggesting that the manual labor conditions of free people at the time were often worse than those slaves faced) (Sheriff 1997). This is an example of the kind of conceptual and contextual contradictions that need to be addressed with regard to cosmopolitan inclusion/exclusion as well.
} 
States. According to this prevalent narrative, illegal immigrants need to be excluded because they are stealing jobs away from Americans who want to work but cannot find employment. The problem is not with the inherent dynamics of post-industrial or late capitalism in America, but instead the problem is that we have failed to exclude the undeserving. Conversely, much of the argument for allowing illegals to stay is based on an idealization of exploitation: "Let them stay; they do work no Americans really want to do like clean our toilets and mow our lawns." Inclusion here is the desire to work under a moderately more benevolent system of wage-slavery. The psycho-social dimensions of capitalism, with competition and dehumanization being the most noxious, pervade discussions and decision-making around citizenship and immigration policies as well. These are just two of the most obvious examples.

In order to appreciate the paradoxes and contradictions of political exclusion and inclusion, we must more fully appreciate the quality of that exclusion and inclusion, even more so than has been elaborated thus far. Post-Marxist thinkers like Hardt and Negri and Etienne Balibar have all gone to great lengths to explore the contradictions between the calls for increased political inclusion (which this project supports) and the nefarious and deleterious quality of the expanded inclusion under global capitalism and the false democracy of neo-liberalism. Hardt and Negri call on the micro-resistances of the multitude; Balibar shares much of their sentiment but adds his own unique discussion of the historical and contemporary discourses of equality and liberty ("equaliberty") by hypothesizing radical transformations of existing political institutions and the construction of novel avenues of bottom-up progressive reform; and Žižek calls for a re-vitalization of the idea of communism without class struggle as well as for less "liberal" action, arguing 
that the continual call for volunteerism, charity, and philanthropic purchases (e.g., "Ethos Water" from Starbucks) actually support the evils of capitalism much more than they undermine them or help the people who are being harmed by them. What then might a solution that responds to the core of the Left cosmopolitans' grievances and the contradictions pointed to by these post-Marxists - as well as the transformational apathy (lacking interest in intentionally fundamentally changing the existing system) caused by the negative dialectical psychological components of the capitalistic mentality developed above-look like?

Linklater (1998) argues that discourse ethics at the global level is the primary method by which the necessary "triple transformation of political community" can occur. By the triple transformation of political community, he means "creating [1] social relations which are more universalistic, [2] less unequal, [and] [3] more sensitive to cultural differences" (17). It is through the fair procedures of discourse ethics that these transformations can occur fairly and justly, and in myriad contexts. The necessity of this kind of emancipation-oriented approach is based on the perspective that existing forms of socio-political organization are inadequate to address the problem of transnational harm, ${ }^{16}$ broadly construed, but also in order to have internationally institutionalized "dialogue and consent replace domination and force" as the primary modes of national and global politics. If one were to reject this normative position, that at the very least domination and force are unsatisfactory modes of resolving political disputes and that coercion-free dialogue and consent would be more satisfactory, then one likely would not accept the vision Linklater

\footnotetext{
${ }^{16}$ Transnational harm can be interpreted in locally, culturally sensitive, contingent ways - therefore it is not simply an alternative "foundation" in a philosophical sense. This is also a concept that Linklater has gone on to write an entire treatise on. See The Problem of Harm in World Politics (2011).
} 
presents based on this normative assertion (21). "[The hope is] the modern society of states may yet turn out to be the first international society which is not destroyed by conquest and war but transformed peacefully by the normative commitment to extending the moral and political boundaries of community" (9). "Breaking with the classical nation-state, postWestphalian communities would promote a transnational citizenry with multiple political allegiances and without the need for submission to a central sovereign power" (181).

Linklater's theory, as well as Seyla Benhabib's cosmopolitan federalism, which will be explained more in the first chapter, draws heavily from Jürgen Habermas' theories of communicative action and discourse ethics. It is likely this root in the more socialdemocratic politics of Habermas that Linklater's and Benhabib's apparent disregard for the psychology of capitalism stems, but sadly this oversight finds its way into their political conclusions as well. Communicative action, according to Habermas, is contrasted with strategic action. In strategic action the goal of behavior is typically self-interested or selfcentered. Deception and coercion are acceptable because the prevailing principle is not "the force of the better argument," but rather competition, strategy, and compromise for one's own benefit rule. Communicative action on the other hand, is based on the ideal that the better argument should rule based on reasons potentially acceptable to all-affected. Communicative action is made possible by progress towards post-conventional moral reasoning and its concern for justice over other kinds of principles; deception and force are precluded (Habermas 1990, 58, 90, 109, 128-135). Communicative action should be viewed as a behavioral ideal consistent with democratic socialism, whereas strategic action in the twenty-first century should be correlated with and critiqued as the logic of capitalist 
systems. With these political-economic associations their inherent incompatibilities are made more explicit, at least on a mass scale.

Absent any thoughtful dealings with the problem of alienation on behalf of liberal capitalists and cosmopolitans, I remain with the position that the social character ${ }^{17}$ that capitalism fosters is antithetical to the post-conventional moral perspective and the kind of ubiquitous communicative rationality and discourse ethical institutionalization required by an inclusively motivated cosmopolitan federalism like the ones implied by Linklater, Benhabib, and others. Though the broadly Habermasian cosmopolitan tradition will only comprise about half of the kinds of cosmopolitanism addressed in this project, the critique of the system/life-world separation and the problem of strategic action under capitalism form the most philosophically nuanced foundational problem of all the cosmopolitan theories. For the other cosmopolitan theorists like Pogge, Held, Beck, Ingram, and others, the lack of engagement with the psychological dimension of capitalism is comparably problematic though for specifically different reasons than what were just stated with regard to the Habermasians.

"The first requirement... of the new society is to be aware of the almost insurmountable difficulties that such an attempt must face....those who have not given up hope can succeed only if they are hardheaded realists, shed all illusions, and fully appreciate the difficulties. This sobriety marks the distinction between awake and dreaming 'utopians' (Fromm 1976, 173). Now that the diagnosis and the necessity of change have been sketched out, we still need to address the question of how in more detail; how might we achieve a post-capitalistic mentality or postcapitalism more broadly? What

\footnotetext{
${ }^{17}$ See E. Fromm The Fear of Freedom (1994), Man For Himself (1990), and To Have or To Be? (1976) for more detailed discussions on his original concept of social character.
} 
must a successful process towards the next social epoch entail so that the ills of the current (or previous) system are not reproduced?

\section{Empowering Postcapitalism}

It is hopefully apparent at this point that for the aspirations of cosmopolitanism to be achieved, it is not enough to be "more realistic" as Beck and Beardsworth among others have suggested (Ingram 2013), but instead that we must develop a truly radical critique of the relationship between capitalism and cosmopolitanism that aims towards a socialist, or at least postcapitalist, future. The ideals of cosmopolitanism are best represented by a postcapitalist democratic world order, an idea that will be argued and developed in each chapter of the dissertation. To address the dialectics of cosmopolitanism completely, a foray into the realm of post-capitalist theory is an order. ${ }^{18}$ This foray will result in a similar though less egregious failure to appreciate the negative dialectical problematic of the capitalistic mentality. ${ }^{19}$ In this case, the contextualization of the problem of the capitalistic mentality is not so much that capitalism undermines the solidarity needed to achieve a more just cosmopolitan future, but additionally that the capitalistic mentality requires that the binary of revolution and reformism be re-thought. ${ }^{20}$

\footnotetext{
${ }^{18}$ Here the key aspects of the post-capitalist theories of Erik Olin Wright and the duo of J.K. GibsonGraham will be exemplars of the kind of interrogation that will be further expanded on to include the postMarxist thinkers mentioned previously (Hardt and Negri, et al.).

${ }^{19}$ Less egregious in that the post-Marxists actually discuss the dynamics of capitalism in a serious manner beyond merely the ills of poverty or ecological destruction.

${ }^{20}$ Again, the binary of revolution and reformism will be contextualized more comprehensively in chapter four. What is presented here are two contemporary attempts to re-think the question of what "radicalreformism" (though this is Fromm's term not theirs) might look like in the twenty-first century.
} 
The question that preoccupies us here is what to do now, and in the near future. There have been progressive attempts to put a nicer face on capitalism, to reform its rougher, meaner, more patently dehumanizing aspects (e.g., through minimum wages, child labor restrictions, and work week limits in certain parts of the world), but there are still places around the world where capitalism has spread where these reforms are only distant pipe dreams. Yet, with the happier face of capitalism there is still the capitalistic mentality, the inherent crises, and evolving and increasing ecological catastrophes. Most educated people around the world (at least in the Western world) tend to see capitalism as part of the solution not the central problem.

For those of us fortunate enough to have received expensive educations and to have come to understand the nuances of capitalism and its (self and other) destructive nature, the question remains, as Lenin put it aptly in the title of one of his most famous works, "What is to be done?" What can we do? What should we do? What are the possibilities that anything we do can make a substantial difference in the way the world functions? The question I didn't include in this initial series is perhaps the most central question of Erik Olin Wright's Envisioning Real Utopias (2010) and J.K. Gibson-Graham's The End of Capitalism (as We Knew it) ([1996] 2006) and A Postcapitalist Politics (2006) in their works that will be examined here: What are people already doing? Though these theorists' works offer vital insights (as will the theorists discussed in the full version of this chapter) these responses remain inadequate for much the same reason as contemporary cosmopolitanism, in all of its versions has failed; they fail to properly understand the detrimental influence of the capitalistic mentality. 
Erik Olin Wright, an avowedly Marxist sociologist, has been a longtime praxeological theorist of class. However, it is not his extensive work on class that is of significance here. It is his most recent work Envisioning Real Utopias (2010) that is of great importance to the Marxist and post-Marxist arguments and goals for moving beyond late capitalism to a more just and humane system of human organization. Wright seeks to show, in ways similar to Gibson-Graham, that there are indeed seeds of opposition, of noncapitalist, of anti-capitalism that are actually highly successful in the current world. He begins with four examples: the city budgeting process in Porto Allegre, Brazil; Wikipedia; the Mondragon collectives in Spain; and the Namibian experiment with a Universal Basic Income system (2010, 2-4).

In addition to showing how capitalism is not nearly as hegemonic and totalizing as it is often believed, Wright elucidates two major theoretical programs that could serve as models for constructing an entirely new global economic system. The first is the market socialism of John Roemer (246-251) and the second is Michael Albert's Parecon (or participatory economy) (252-265). Market socialism allows for a functioning market economy but instead of continuing the expropriation of surplus value, the defining characteristic of capitalism, Roemer argues for the social, collective, or worker ownership of the means of production. There can be profit, but it would be distributed equally among the workers, or at the very least—in the fashion of Mondragon—profit distributions would be decided democratically by the workers.

In the more radical and original approach of Albert, Parecon is "a non-market participatory democratic economy" (252). There are five principles of Parecon: 1. Social Ownership; 2. Egalitarian democratic empowerment (which means that citizens have 
"influence over decisions in proportion to the degree he or she will be affected by them" (254); 3. Job Complexes; 4. Remuneration according to effort/sacrifice and need; 5. A decentrally planned economy. This last point is very important because it hits on the key failures of the attempts within China, the USSR and other supposed attempts at socialist economies. The main idea is that the economy will be planned but not by a national-state government council of bureaucrats but instead planned democratically.

For Gibson-Graham the supposed first steps are: undermining the discourse of hegemony while presenting an alternative while promoting optimism through a more accurate understanding of existing opportunities and possibilities for being and becoming otherwise, because some people are already being and becoming otherwise, against the grain of the hegemonic discourse of capitalist omnipotence. For other thinkers like Laclau and Mouffe and Nick Srnicek and Alex Williams, is to develop a radically-democratic counter-hegemony against and to replace the dominant capitalist material and discursive hegemonies. For Hardt and Negri, who offer a radical reconceptualization of capitalism (as Empire) and the proletariat (as Multitude), the almost-teleological development of Empire produces its own grave-diggers embodied in the Multitude which is guided by the logic of the Common as Empire's increasing reliance on technological-service-knowledge-based labor creates a globalized situation where traditional conceptions of property and ownership will increasingly be seen as archaic, inefficient, and undesirable.

What it will take to implement a postcapitalist strategy or strategies from a consciousness perspective is a bit more complicated. This issue will also be addressed in chapter four, but it is worthwhile to say a bit more here before moving on. Fromm pointed out through his career, culminating with To Have or To Be? (1976), that people need to 
realize they are being harmed before they will take action to mitigate that harm. The problem is that capitalism and its evil-twin consumerism make a lot of people very comfortable and thus complacent, while simultaneously making a lot more people completely dependent on capitalist enterprises to acquire the basic necessities for survival or for any chance at obtaining a more secure lifestyle. For Fromm, as with Olin Wright, awareness combined with social empowerment are the keys to substantial change (though he underemphasizes the importance of awareness). Fromm himself made pleas for reeducation, which, coming from an avowed radical socialist (Marxist) in the US during the Cold War, fell on what could be politely called deaf ears.

Without a radical change in the way our governments educate young, soon to be citizens, and the ways our media (de)educate our adults, empowerment will continue to fall short of what it otherwise might. The only way I can see this happening is for more conscientious intellectuals who understand what is happening and what needs to be happening to get into conversation with others, around the world (as in the World Social Forum and other sites where there can be interactions with other people, working people), and engage with them as equals with different experiences, knowledges, and ideas to contribute, in such a way that we can learn from each other in substantial ways that promote progress away from capitalism, towards whatever instantiation of egalitarian, just postcapitalism might emerge as a result.

This is where Fromm's (1955) concept of “radical reform” comes in. Fromm's idea of social character and the combined Frommian-Adornoian concept of the capitalistic mentality evinces a serious problem for revolutionary Left theories of progress: if the structures of the capitalist economy were to collapse tomorrow capitalism would be gone 
but the psychological conditioning and behavioral manifestations of that conditioning would be left fully intact in the minds of most people (and increasingly more people every day as globalization continues). Merely allowing capitalism to take its course without ensuring that a new kind of person emerges from the rubble of the old system, chaos would likely ensue, or at least a less institutionalized chaos than we already have. The problem is not that people are naturally avaricious, competitive or exclusively or primarily selfinterested. The problem is that capitalism has further instantiated these ideas within the minds and everyday practices of the subjects of capitalism. If the system is going to change then the people need to change, and this change of mentality must precede the collapse of capitalism in order to be most effective.

Adorno would surely agree. The more reified and fetishized our views of what is natural and just become, the further from a just and free society we move. Reification, identitarian thinking, the marketing social character, the having mode of existence combine to elucidate the most destructive component of capitalism, this variable between the base and superstructure, this capitalistic mentality is parasitic to progress, and more specifically to this project it is parasitic on cosmopolitan and emancipatory political theory and political action. The conclusion reached through a negative-dialectical reading of Balibar's earliest work on the dictatorship of the proletariat (written in the context of heated debates with his teacher and comrade Louis Althusser and the wider French Communist Party in the 1960s and 70s), is that is an almost-ironic rejuvenation of the concept of the dictatorship of the proletariat through Rosa Luxemburg's recharacterization of it as "unlimited democracy" (Luxemburg 2006, 219). One need only look back to Marx and Engels' comments on the Paris Commune to see that for these communist thinkers, the dictatorship of the proletariat 
was never meant to be anything resembling what we think of when we think of a dictatorship, which is why in her interpretation of the concept Luxemburg referred to it as "unlimited democracy" (better capturing the extension of democracy needed as a corrective to Ingram's more limited conception of democratic universalism — which remains within the ethico-political realm, not necessarily extending beyond the institutions and practices of more conventional politics)(220). The value of Luxemburg's concept here is that it captures what she believed was the radically anti-/post-capitalist democratic elements latent in the concept of the dictatorship of the proletariat, but because that concept, at least superficially, implies the opposite of democracy, it allowed bourgeois capitalists to retain their unjustifiable claim to the mantle of democracy. Unlimited democracy in this way directly challenges bourgeois democratic formalism that is restricted from being extended into economic, social, and cultural realms.

The exposition offered in chapter four is also dialectical with respect to the concept of the proletariat. Drawing on the concept of the capitalistic mentality, as well as the neo/post-Marxist thinkers that are discussed in chapter four, that the proletariat can no longer be viewed at the universal-revolutionary class. While workers definitely have the greatest interest in radical structural changes that move us beyond capitalism, the capitalistic mentality acts as a kind of block between what E.P. Thompson called class-in-itself (the structural existence of a working class) and class-for-itself (the self-conscious awareness of the members of a class that they are indeed a class with a particular shared set of interests). While proletarianization is certainly increasing, and labor movements certainly continue to exist and struggle, there is little evidence that increased proletarianization actually produces an increased anti-/post-capitalist class-consciousness, at least not in the 
late twentieth and early twenty-first century. ${ }^{21}$ By looking at class negative-dialectically and with the analytical strength of the concept of the capitalistic mentality, I am able to maintain an emphasis on capitalism as the overarching mechanism by which consciousness (and resistance possibly) may be produced, but without reifying the proletariat. As David Harvey (2016) and others have argued, it wasn't just the workers that comprised the Paris Commune. It was the unemployed, the urban dwelling poorer merchants, and women (Draper 1962).

There are moments throughout this dissertation that will feel hopeless-especially towards the end of chapter three. In the many places I have presented parts of this work, the question I so often get is, "where is the space for agency?" which is itself an interesting question given that one of the crucial theoretical figures deployed in this argument was castigated throughout his career for giving too much pride-of-place to individual and even collective agency. While my work here certainly more accurately portrays Erich Fromm's very real pessimism about the likelihood of success for any radical reformation on a massive scale, there are often spaces for agency. It will always be a differentiallyconstrained and conditioned agency — not an agency outside of the forces of ideology that become the incentivized, normalized, and justified capitalistic mentality-but there is definitely space for hope. It is, as China Miéville (2015) in Salvage has called for, a "hope with teeth." It is a "hope without optimism" to use Terry Eagleton's (2015) phrasing. We have no reason to think things will turn out well, but the truth that they possibly could with the right collective actions and changes in the too often cold-heart of humanity, is what we should be focused on. Despair. Be pessimistic. There is ample cause for both, but that can

${ }^{21}$ This is despite the arguments made in Smith (2016) and Ness (2016). 
and must be combined with a critical hope aimed at theorizing, developing, and practicing (in no particular order) alternatives to the current way of organizing our world and alternatives to our current ways of thinking (or at least what currently passed for thinking). It must not begin with each of; it must begin first with us - in whatever collectivities we can create together-democracy can help us recreate one another with psycho-social incentives that countermand and delegitimize the capitalistic mentality. This project aims to offer a contribution to the intellectual and practical conversations that have attempted to offer elements of such a critical hope and vision.

\section{Chapter by Chapter Breakdown}

What critical cosmopolitanism and cosmopolitanism in general has failed to fully appreciate is how what I will call the "capitalistic mentality" undermines cosmopolitan and emancipatory-socialist progress. The capitalistic mentality is a psycho-philosophical mindset that permeates late capitalist society and is being progressively globalized through the spread of global capitalism. It promotes and incentivizes competition over cooperation, instrumentality over critical thinking, and greed over contentedness and sharing (to name just the most obvious). Throughout these chapters, cosmopolitan theory will be brought into progressive interaction with more explicitly (neo- and post-) Marxist theories resulting in a substantial contribution to both theoretical traditions, as well as to critical political and international theory more broadly. This contribution will involve articulating a comprehensive normative theory of dialectical (i.e., Critical-Theoretical and Post-Marxist) cosmopolitan federalism while never failing to self-reflect on its own inherent shortcomings. 
Chapter one will explore the fundamentals and nuanced boundaries of contemporary cosmopolitan theory. The focus of this chapter will be to examine how capitalism is treated in contemporary cosmopolitan theory. The goal of cosmopolitanism is a more just and inclusive global order which privileges universalizable human political, social, and economic rights and yet by ignoring or wrongly evaluating the true nature of capitalism this goal can but remain in the distance. This chapter will serve as the launching point for the critique of cosmopolitanism which culminates in the critique of existing postcapitalist theories in the final substantive chapter.

The second chapter will explore the critiques of capitalism offered by Marx and Frankfurt School Critical Theorists Theodor Adorno and Erich Fromm. The main argument in this chapter is that there exists a generalized "capitalistic mentality" that is pervasive within the totalizing system of global capitalism, that capitalism instantiates itself through reproducing ideological hegemony in the form of psychological dispositions and the resultant normalization of a particular behavioral paradigm. From Adorno the key ideas will be negative dialectics and identitarian thinking and from Fromm the marketing social character and the having mode of existence.

The third chapter will expand on the ideas discussed in the first and second, moving on to offer an original Critical-Theoretical critique of cosmopolitanism. The argument will combine and expand on the two streams of thought developed in the first two chapters. The point here is to show how cosmopolitanism and capitalism are incompatible because of the nature of the capitalistic mentality. The example discussed in this proposal is the relationship between strategic action, capitalism, and everyday psychologies which hinder the emancipatory horizon of communicative rationality from emerging on the widespread 
scale that would be needed to achieve the normative visions offered by thinkers like Benhabib, Linklater, Ingram and Cheah. The capitalistic mentality as a critique will be applied to the other forms of cosmopolitanism as well though including the more liberal work of Charles Beitz, Thomas Pogge, and David Held.

The fourth chapter will rearticulate the key aspects of Adorno's and Fromm's potential usefulness in contemporary critical theory especially when put in conversation with other post-capitalist critical theories (though some, like Laclau and Mouffe, have moved away from a direct critique of capitalism). This chapter will explore the work of a variety of thinkers in the neo-/post-Marxist tradition, all of whom have in a variety of different ways rejected the stereotypical notion of revolution as the path towards egalitarian-democratic postcapitalism-which as Fredric Jameson has pointed out was never meant to be a quick or temporally-compressed project (Jameson 1996). While looking through Adorno's and Fromm's explicit suggestions on topic as well as their implicit support of a non-identitarian (negative dialectical) revolutionary-reformist Marxism, the basic idea of which is that a "fast revolution" is no longer tenable (if it ever was - as this is something that Marx was at least vague if not contradictory on in the several places he comments on revolutionary strategy or examples he was witnessing), but at the same time legal reformism is not a viable alternative as it has been conventionally formulated (beginning in the work of Eduard Bernstein through to today's left-social democrats). Therefore, the only options left to us are those that live in the ambiguous, dialectical conceptual space between revolution and reform. In other words, reform needs "to be made" radical, which is the one of the implicit unifying strands in the diverse works of Adorno and Fromm and one where the psycho-social elements of which are 
underdeveloped in the works of many of these prominent neo-/post-Marxists. Using both Adorno and Fromm the limitations and avenues for possibly getting around some of those psycho-social and structural limitations standing in the way of emancipatory (real utopian) progress will be highlighted though left relatively open for further exploration.

The conclusion here explores the potential for a post-capitalistic mentality that is both socialistic and firmly rooted in many of the most worthwhile, tenable, de-reified elements of the cosmopolitan thinkers discussed throughout.

\section{A Note on Methodology and Style}

It is important for the reader to understand the intellectual spirit in which the project will be written, and although that spirit will evince itself throughout the project without explanation, understanding the intentionality of that spirit and associating it with a particular mixture of theorists (in this case Adorno and Fromm) is better served by an explicit explanation.

I have attempted to apply a complex mixture of Adornoian negative dialectics with the accessibility and normative democratic ethos of Fromm's theory and writing-style in general. Scholarly debates and jargon are unavoidable in a dissertation, but in combining Fromm's method with Adorno's intellectual elitism, an original contribution to knowledge is allowed to come to fruition that is sophisticated, accurate, occasionally playful, demystifying, and comprehensible to a reader lacking in-depth knowledge of any of the traditions or thinkers referenced herein. The primary goal for this dissertation, as with any work of critical scholarship, is to expose the complexities the current social situation that fail to be apparent on their own or through existing scholarship. Yes, negative dialectics 
and radical psychoanalytic humanism are decided starting points, their usefulness and practicability will be explicated and justified by the end. These are not just the theoretical tools that I will be using to analyze cosmopolitanism and contemporary critical theory, but they are also the methodological and stylistic inspiration behind the explicit applications of these theorists as instrumentalized analytical and normative tools. As with any sophisticated application of negative dialectics, the arguments made here have, as much as is possible, acknowledged their own non-identity and potential contradictorinessthough for the sake of readability and avoiding the appearance of excessive hedging, this was not done in every instance. I hope that sympathetic readers will not ignore these moments, but instead take them as opportunities to think beyond my arguments and concepts. The most a scholar can hope for is that their work will change the world, but more realistically, what I hope for is that my work here can (re)start a conversation between all those who are concerned with global justice and addressing the very real ills that face our planet, with the worst of the burden of those ills-as always-shouldered by those least able to shoulder them. The "methodology" employed here, due to its inherent critical gaze and lust for unraveling conceptual, argumentative, and real-world contradictions, is one that is shown to be fruitful not just in this project, but for future scholars as well. 


\section{CHAPTER 1 \\ Assuming the Status Quo: Cosmopolitanism Takes on Capitalism}

\section{Introduction}

Generally, normative theories of cosmopolitanism (excluding those that tend to make more empirical observations regarding the development of a global community or something akin to that $)^{22}$ deal with the global economy in some way, even if only tangentially. The major problem with all of these theories of cosmopolitanism is that they either fundamentally misunderstand capitalism or work with a substantially incomplete definition of capitalism. As will be made more clear in the next two chapters, any theory of cosmopolitanism - or even Marxism as will be argued in chapter four-must grapple with the psycho-social aspect of capitalism, as opposed to hyper-focusing on its contingent, though historically pervasive, economic dimensions like markets, which are only sometimes historically connected to capitalism and surely not its defining characteristic, despite widespread claims to the contrary. ${ }^{23}$

All of the theorists presented in this chapter are in some way representative of a particular approach to cosmopolitanism and a corresponding theory of global justice. Within this group there is a wide variety of takes on the global economy ranging from a duty to promote (sometimes sustainable) development of the Third World to worldwide redistribution of wealth (akin to what we see on the nation-state level in the Scandinavian social democracies, the United Kingdom, and Canada). What this chapter will not do is provide a comprehensive look at the likely hundreds of different versions of

\footnotetext{
${ }^{22}$ For example, see the work of Tim Robbins and Kwame Appiah.

${ }^{23}$ Defining capitalism, specifically focusing on its under-theorized psycho-social dimensions, will be one of the central goals of the next chapter.
} 
cosmopolitanism that are out there. It will also not rehash the debates regarding the nature of citizenship or borders, importantly connected to the liberal-communitarian debates of the $70 \mathrm{~s}, 80 \mathrm{~s}$, and $90 \mathrm{~s}$ that is at the core of much of the academic debate around cosmopolitanism. This chapter will explore some of the most important and recognizable examples of cosmopolitan theory, all of which address global economics in the context of global justice - even if their emphases are not explicitly economic or whether they use the term "capitalist" to describe those economics. The conclusion that will be reached is that there is a pervasive inadequacy with which the global capitalist economic system has been addressed by these theorists, all of whom are ostensibly concerned with issues directly related to the structures and effects of the global economy, especially inequality and poverty.

This chapter divides these politico-ethical cosmopolitanisms into three groups. These groupings are analytical, and are primarily based on the intellectual traditions the particular thinkers place their work, but are also based on the substance of the arguments themselves. The groupings are pragmatic as opposed to representing some kind of essential characteristic(s), though there are strong similarities in most cases. First, (1) the mainstream international distributivists including Charles Beitz, Thomas Pogge, and David Held; second (2) the "critical" cosmopolitans who have placed themselves in the tradition of the Frankfurt School of Critical Theory including Jürgen Habermas, Andrew Linklater, and Seyla Benhabib; lastly (3) are the self-described radical cosmopolitans James Ingram and Pheng Cheah. ${ }^{24}$ The mainstream perspectives are the most Kantian, the second, critical

\footnotetext{
${ }^{24}$ Noticeable thinkers who have been excluded from my analysis, but who are often included in typical discussions of cosmopolitanism are John Rawls (whose political theory will be mentioned as a foundation for Beitz and Pogge's work), Martha Nussbaum and Amartya Sen. These thinkers' ideas are captured well by the discussion in Section 1. Notable exclusions in the "Critical" section (2) are James Bohman, Nancy
} 
group is somewhat Kantian, moving beyond Kant in important ways, and the final group is the least Kantian and the most Marxian (without being Marxian or Marxist). It will not be until chapter three where we feel the full effects of the inadequacy detailed in this chapter, and when we get there, even Kantian cosmopolitanism will be shown to have a problematic relationship with the actual dynamics of global capitalism, contrary to hisand these aforementioned theorists'-claims otherwise (See Kant's 'Perpetual Peace"[1991]). ${ }^{25}$

\section{(1) Mainstream Cosmopolitanism}

\section{A. Beitz and the Foundations of International Justice}

This discussion should begin with the text that really made the subfield of international political theory a recognizable, if still underappreciated, one, Charles Beitz's Political Theory and International Relations ([1973] 1999). Prior to Rawls's student Thomas Pogge offering his critical appraisal of Rawlsian theory beyond the nation-state, and before Rawls articulated his own application of his theory of justice to the international realm, Beitz used Rawls's theory to expound a thoroughgoing critique of the nation-statecentric orientation of much of international relations theory, specifically realism and other

Fraser and perhaps Ulrich Beck. With regard to exclusions of radical or anti-capitalist cosmopolitans, I am unaware of any other than perhaps Stephen Eric Bronner whose theory of the "Cosmopolitan sensibility" could be construed as such. Though because he lacks a consistent relationship to this literature as well as a comprehensive approach to cosmopolitanism, he has been excluded. Thinkers like Hardt, Negri, and Etienne Balibar who engage with this literature from a Marxist or post-Marxist perspective will be addressed fully in chapter four.

${ }^{25}$ It is actually in these Kantian roots where I suspect much of the complicity in and acquiescence to global capitalism within the contemporary cosmopolitan tradition, so focused on global justice and forming ethical political societies, has derived from. Where does the connection between cosmopolitan justice and global capitalism originate? It is not with the Stoics (the originators of cosmopolitan political philosophy) but rather with Kant's proto-capitalist philosophizing on the possibility and content of sustainable world peace due to the civilizing effects of the marketplace's demand for stability and order (again see "Perpetual Peace" [1991]). 
Hobbesian-inspired approaches. In this seminal text, Beitz does very little reflection on the merits of Rawls's theory, taking its coherence and normative prowess for granted (and explicitly so). As Beitz reminds us throughout his text, if one is not convinced of the merits of Rawls's neo-Kantian constructivist conception of justice, one is not likely to be convinced by Beitz's. However, one need not be sympathetic to Rawls to accept Beitz's critique of the Hobbesian conception of the international state of nature proffered by many realists. However, it is not primarily in Beitz's argument that there can be no straightforward analogy between the individual person and the nation-state with regard to morality and moral obligation where we find his take on capitalism (even if this is not a word that he uses). This critique of the state centricity of the status quo in IR is the foundation for what Beitz eventually does say about the global economy: the idea that there are principles of justice that should normatively shape international relations, and that legitimacy should not be connected to assume state sovereignty nor should the supposed existence of international anarchy be believed to undermine the efficacy or importance of such potential principles of international distributive justice.

Before getting further into Beitz's approach it will be useful to summarize the key elements of Rawl's political philosophy from which both Beitz and later, Pogge draw heavily. What is important to understand from Rawls in regards to Beitz's (and Pogge's) theory are the definition of justice and how it is that we come to understand what the principles of justice are. ${ }^{26}$ Before getting into the more notable dimensions of Rawls' theory, like the original position and the veil of ignorance, we need to understand how

\footnotetext{
${ }^{26}$ Aspects that are not as relevant include Rawls' approach to deliberative democracy nor is his Law of Peoples (2001) especially relevant (though many scholars have compared various cosmopolitan theories to the Law of Peoples, itself not a theory of cosmopolitanism according to Rawls himself).
} 
Rawls defines systems where principles of justice are possible. Principles of justice are relevant to societies or any cooperative social scheme designed to increase the well-being of the participants, beyond the level they would be at without cooperation (Rawls 1971, 4). The question of justice refers solely to the structure and institutions that shape that cooperative social scheme and not to the behavior of individual actors (7). It is also worth emphasizing that even more so than with Beitz-who vacillates between ideal and nonideal theory—Rawls takes an approach which is intended to be purely ideal. Rawls' reason for focusing on the ideal conditions is precisely to avoid the messiness and complicated nature of non-ideal situations. The goal is to figure out what we should be striving for in non-ideal conditions to make them more ideal (9).

How is it then that Rawls tells us how we can figure out what the ideal principles of justice could or should be? He takes a constructivist Kantian approach through a hypothetical thought experiment grounded loosely in the social contract tradition. Based on the supposed insights of neoclassical economic theory, the participants who hypothetically determine the principles of justice who are situated in an original position (that is pre-social and pre-political), are foundationally defined as persons who are rational, self-interested, and risk-averse but primary-good maximizers. Primary goods are ostensibly neutral and that, regardless of whatever else he (Rawls uses the purely masculine pronoun throughout) wants, he wants these certain foundational good. A bit more specifically, according to Rawls, primary goods are: "rights and liberties, opportunities and powers, income and wealth" and a sense of worth $(1971,92)$. These purely rational persons are also, provisionally, entirely ignorant of their own identities. They have no knowledge of their life conditions, education level, family situation, or their natural skills or handicaps. 
They do not even know the basic history of the society they are "representing." This hypothetical idealized limitation in the original position is what Rawls calls the "veil of ignorance" (12-13, 136-139). The principles of justice that Rawls argues the rational, ignorant participants in the original position would come up with are: (1) The Equal liberty principle and (2) equal opportunity and difference principle. The equal liberty principles states: "each person is to have an equal right to most extensive basic liberty compatible with a similar liberty for others." The equal opportunity and difference principle then adds: "social and economic inequality is are to be arranged so that they are both (a) reasonably expected to be to everyone's advantage, and (b) attached to positions and offices open to all" (60).

The purpose of this thought experiment is for us, people already in a society, already in this cooperative scheme for mutual benefit, to critically self-reflect on how much deviation there is in our current social, legal, political, and economic structures from ideal principles we would all assent to if we weren't constantly trying to accumulate more primary goods for ourselves based on our knowledge of what skills we have and our precise situation in life, seemingly regardless of the consequences. If we combined Rawls' argument regarding when questions of justice are relevant to a particular group of agents with Beitz's critique of the supposed ubiquity of isolated anarchy in the international realm, we can begin to see how Beitz's argument for a more international conception of justice is supported (Beitz 1999, 131-133).

Getting more concrete now, Beitz begins his discussion of international economics in his initial discussion of the sovereignty-based claims for non-intervention in the internal affairs of another state. He focuses this discussion on the question of whether or not in the 
post-colonial world, especially now in a post-Cold War context, there is still inherent intervention in the internal affairs of other countries through the perpetuation and cultivation of dependence by the very nature of the development of global markets. This is especially important as the ideals of international free trade become more and more normalized (1999, 116-117). Beitz goes far as to briefly summarize Lenin's thesis that imperialism is the highest form of capitalism, while never acknowledging more than that is one particular take on capitalism and globalization. He then tells the reader that it is a bit trivializing to suggest that the most pernicious consequences of economic dependence and political imperialism are the losses to national autonomy, and instead are more accurately described as violations of fundamental principles of justice, particularly consent (117-119). "The exercise of coercive power requires justification," regardless of whether that coercive power is foreign or domestic, or primarily political or also economic (119). "The objectionable features of dependence-like excessive exercises of state coercive power or large internal distributive inequalities — might be reproduced by an apparently autonomous state" (120). Beitz does not actually offer any more substantive critiques of Lenin's deeply technical and empirical critique of capitalism as imperialism (and imperialism as capitalism).

Self-determination, as a function of consensual politics, "should be understood as a means to the end of social justice... [and] where it is true that the international economic relations characteristic of dependence contribute to the maintenance of domestic injustice...there is clearly room for moral criticism" (120-121). According to Beitz, this is the most egregious dimension of the global economic system: the perpetuation or support of unjust domestic institutions (122). He concludes this section boldly: "the development 
of just domestic institutions in many societies may depend on the elimination of international distributive injustice" (123).

Overall, Beitz offers two different bases for his argument for international distributive justice. The first is that the international system produces interference and dependency. Interference is inherent to the global economic system because of the existence of trade agreements and international (multinational) businesses. Dependency is also a side-effect because certain economies require the infusion of certain natural resources, which they themselves do not possess. Similarly, some national economies are reliant on the exporting of their domestically produced goods for sale in other markets. The second basis for Beitz's argument for international distributive justice is that the distribution of natural resources is morally arbitrary. Because the place of one's birth is not chosen and the placement of natural recourses in certain specific geographic or geological areas is not based on any morally relevant procedure, Beitz concludes that similar to the necessity of rationally agreed upon principles in a domestic society, there exist good reasons to believe that there should indeed be principles of international justice, which would have to be rationally agreed upon in something like Rawls' original position thought-experiment.

Beitz does not necessarily specify what those principles would be, but they would broadly include political and civil rights as well as addressing the morally problematic facts of dependency and natural resources distribution (and usage). Again here this is similar to the content of Rawls's original principles of justice, at least in terms of categories of content (one political, the equal liberty principle and one economic, the difference principle) (1999, 127-138). In the end, Beitz fails to offer a cogent set of principles of international justice 
and does not provide a practical path towards their instantiation in the context of global capitalism.

\section{B. Thomas Pogge between the Poverty of Justice and the Injustice of Poverty}

After Beitz we have probably the most well-known of all the contemporary cosmopolitans, Thomas Pogge. His two major works, Realizing Rawls (1989) and World Poverty and Human Rights (2002), form a thorough and passionate analysis of the interconnection between rights and obligations across national borders. Pogge's cosmopolitanism initially developed during his graduate and immediate postgraduate work, and like Beitz's opus, it was heavily based on Rawls. Realizing Rawls represents both a critical defense of Rawlsian theory at the domestic level, and the detailed expansion of the Rawlsian original position, veil of ignorance, and the principles of justice (equal liberty and difference principles) to the global level. Pogge's view, regardless of Rawls's own conclusion to the opposite, is that restricting this conception of liberal social justice to the domestic sphere in the context of contemporary international relations and the world economy (i.e., interdependent globalization) is simply self-contradictory.

Pogge interprets Rawls as being a semi-consequentialist, rather than a neo-Kantian deontologist as suggested by most commentators. The semi-consequentialist interpretation allows Pogge to reemphasize the "engendered" consequences, benefits, and burdens of the current (or any alternative) global political-economic scheme (1989, 274). Based on Rawls's conception of the abstract rational individual, Pogge argues that there is no reason for this person to possess any knowledge of the nation-state they may or may not belong to. In fact, there is also good reason to suspect that even the knowledge of the existence of 
the state-system as such should not be known by the parties in the original position behind the veil of ignorance. The conclusion for Pogge in Realizing Rawls is that because there is ample evidence for the existence of an-at least moderately-interconnected global economy and transnational political institutions where decisions made in one part of the world can and often do affect people thousands of miles away in another country, even on another continent, the difference principle should be understood in a global context. The implication is that any international political-economic scheme which tacitly or intentionally distributes rewards and deprivations must do so to the benefit of the globally least advantaged. This implies that everyone, in order to be treated justly, deserves basic political and civil rights and liberties, "including rights to a socioeconomic position that is sufficient to meet the basic social and economic needs of any normal human participant in the relevant social system" $(1989,147) .{ }^{27}$

In both Realizing Rawls (1989) and World Poverty and Human Rights (2002), Pogge argues that not only is there a negative moral duty to not harm others through the structural or institutional schemes we support, participate in, or merely benefit from, but additionally we are morally obligated by the equality and difference principles to work towards a less unjust scheme. Beyond this broad foundational principle of cosmopolitan justice, Pogge provides additional principles of his version of cosmopolitanism. His wellknown and oft-cited tripartite definition of cosmopolitanism includes: individualism, universality, and generality. Cosmopolitanism thus means that individual persons are the

\footnotetext{
${ }^{27}$ What precisely constitutes a "relevant social system" is ambiguous here. However, later statements in this text, as well as the later World Poverty and Human Rights (2002), explicate an understanding suggesting that the international political-economic system in many ways constitutes such a "relevant social system" in regard to this conception of justice. Pogge's cosmopolitanism is derivative of this and the aforementioned reapplication of Rawlsian theory.
} 
eminent loci of morality and dignity (individualism), regardless of where they were born, they are potentially equal (universality), and these principles and ensuing obligations apply to everyone equally, regardless of anyone's personal preference or attachment for friends, family, or fellow citizens (generality) (2002, 169-172).

Where do these principles lead Pogge in regard to capitalism and the global economic structure? Much of what Pogge has to say about capitalism is limited to his extensive discussions on global inequality and extreme poverty. One would think that such a conversation would at least superficially delve into the defining characteristics of the global economic system that causes and perpetuates such massive inequalities and pervasive destitution. Unfortunately, there are only a few superficial remarks which speak to the fundamental characteristics of capitalism, but are worth mentioning before getting into his specific arguments regarding poverty.

First, in Realizing Rawls, Pogge says, "there is a great deal of space [referring to the situation of the participants in the original position] for institutional alternatives about which persons of good will may reasonably disagree" $(1989,154)$. Then he shortly thereafter states, “existing institutions are not all that successful, in that they don't even remotely satisfy the difference principle (TJ 87). And how can we expect them to so as long as this principle is not incorporated into the public and official terms of the institutional scheme?" (159). In chapter three of the dissertation, the question of why anyone would (supposedly rationally) choose capitalism will be addressed directly specifically referencing the self-reproducing psycho-sociality of capitalism, absent any sufficient redress by Pogge himself in either major text, never mind any of the thinkers that follow. The most explicit reference to capitalism is made in an exegesis on the question of 
capitalism versus socialism within the phase of Rawls's original position transitioning into the constitutional convention, where certain aspects of the veil of ignorance are removed (this is after the principles of justice are agreed upon under the thickest veil of ignorance). Pogge agrees with Rawls's point that either regime is compatible with the principles of justice they suppose the representatives in the original position would assent to (200-203). Lastly, Pogge writes, "[Citizens of affluent countries] must convince [themselves] that the global economic order is not a significant causal contributor to [severe poverty and inequality]. [They] are convinced of this, and convinced that the global economic order could not be modified into a significant causal contributor to the eradication of extreme poverty and inequality" $(2002,111)$.

Pogge believes that the developed Global North bears a special responsibility for alleviating global poverty, and this argument is based on the aforementioned point regarding institutional interaction and benefit. The global system, both economically and politically, is literally "up to us." Though he does not mean this individually per se, but rather "us" as in us collectively, because the Unites States and other major Western government command such an influential role in the formation of international institutions and trade policies and the like, the democratic polities of those states are conferred a great burden of responsibility for the outcomes those institutions and policies engender.

Property and promises, money and markets, governments and borders, treaties and diplomacy - all these do not occur naturally but are invented by human beings and continuously evolve through human conduct. Such institutions are 'up to us,' collectively.... Since social institutions are more or less just depending on how they distribute morally significant benefits and burdens among their human participants, this causal responsibility gives rise to a moral responsibility, which is a collective responsibility for our collective role in imposing existing institutions 
upon, in particular, their most disadvantaged (and involuntary) participants. $(1989,276)$

The use of the word "imposing" is a major dimension of Pogge's understanding of the relationship between the global economy and cosmopolitan justice. Though traditional realist international relations theory or neoclassical economics suggest, or rather assume, that the particular economic decisions and systems employed in a particular country are feely decided upon by the government (and by extension people) of that particular country. Pogge rejects this out of hand. In order to succeed, or even get one's head above water as a national economy, you need to play by the rules of the neoliberal hegemony $(2002,139)$. This is to say nothing of the legacies of imperialism and colonialism that persist to this day in many parts of the world that are suffering the most. For Pogge, cosmopolitanism demands that we work for global political and economic justice, as a negative duty.

We are perpetuating a system that perpetuates real harms. We are morally obligated to reform the global order to the benefit of the least advantaged. The two examples of governmental complicity that have been entrenched in neoliberalism are the international resource and borrowing privileges. It is through these privileges that the international community enables an assumed legitimate government to sell its natural resources without regard for what the payments received will be used for or if the people-never mind the worst off within that country—will benefit in any way, as well as take out loans in the name of the country $(11 ; 112-117)$. According to Pogge, and this is by no means controversial within international law, these states are assumed to be legitimate simply by virtue of controlling the apparatuses of government within a nation-state. "By continuing to support the current global order...without taking compensating action toward institutional reform 
or shielding its victims, we share a negative responsibility for the undue harms they foreseeably produce" $(2002,144){ }^{28}$

Pogge's suggested solution is not a dismantling or even progressive removal of the global capitalist system, but instead he offers the moderate suggestion of the global resource divided. The global resource dividend would collect a tax on any natural resource a country extracts (assuming they did decide to extract it, which they would continue to be under no obligation to do), and the resulting funds would be used for the benefit of the globally least advantaged, in accordance with Pogge's globalized difference principle. In order to achieve this, Pogge does not suggest an alternative mode of production but instead that the international community of nation-states should move towards a vertical dispersal of sovereignty embodied in the global resource dividend, something he refers to as a "moderate proposal," similar to what will be suggested by David Held below. Specific mentions of global capitalism are few and far between, though. It appears that Pogge, as we saw with Beitz and will go on to see with Held and the Habermasians, assumes that capitalism and a global market system can be made humane with enough regulation and redistribution. Throughout, Pogge remains dumbfounded as to how people in the Global North remain so apathetic about global poverty, regardless of whether they accept their own (systemic) culpability, though the denial of this culpability is likely the key reason in his view $(2002,1-26)$.

\section{David Held and Cosmopolitanism as Global Social Democracy}

While anyone who has studied David Held's numerous contributions to cosmopolitanism, and globalization studies more broadly, would be immediately suspect

\footnotetext{
${ }^{28}$ No definitions are offered by Pogge for "undue harms" or "foreseeably produce."
} 
of any assertion that he does not address capitalism with much nuance or depth, this is precisely what I hope to show here. Held surely has made continual efforts to grapple with the intersection of democracy, an increasingly globalizing economic system, and social justice. His (1995) book Democracy and the Global Order: From the Modern State to Cosmopolitan Governance and the (2004) follow-up Global Covenant: The Social Democratic Alternative to the Washington Consensus are the key exemplars of these contributions. In both texts, Held articulates an extremely detailed and nuanced, empirically-informed, statistically-buttressed, theoretical vision of what democracy needs to mean in our age of intensified globalization (understood economically, politically, and culturally). Held values regulated markets, vague though important notions of redistribution of wealth, democratization, and a broad package of liberal rights to be guaranteed and enforced through cosmopolitan (read global or transnational) public law embodied in reformed or entirely new international organizations and regimes. Compared with all the other thinkers in this section, and probably the entire chapter, Held's cosmopolitanism is the most empirically oriented. This is not to suggested it is theoretically unsophisticated in any way, but rather, contra the other approaches which one could accurately describe as being "normative political philosophy," Held's is better labeled "ethically-motivated, theoretically-informed, global public policy."

In Democracy and the Global Order, Held specifically articulates the centrality of the principle of autonomy for any conception of democracy, and in an age where globalization has come to make certain dimensions of society, politics, and economics subject to transnational forces, autonomy must be reconsidered and reemphasized. “...[A] theory of democratic politics must take account of the place of the polity within geopolitical 
and market processes, that is within the system of nation-states, international legal regulation, and world political economy" (1995, ix, 71, ...). Democracy requires responsibility towards others beyond our national boundaries or cultural communities so that a "common structure of political action" which can rehabilitate the entire notion of democracy in an era of increased transnational interaction (xi). "In an age in which there are many determinants of the distribution of power, many power centres and authority systems operating within and across borders, the bases of politics and of democratic theory have to be recast. The meaning and nature of power, authority, and accountability have to be reexamined (22). As the modern nation-state becomes increasingly, though never fully (neither empirically nor normatively) superseded by supranational forces like global finance, climate change, or migration, new supranational institutions are needed to overcome the correlative democratic deficit emerging throughout existing regional and global IGOs $(93-98 ; 121)$.

The specifically economic aspect of Held's conception of cosmopolitanism begins with a rejection of both free-market liberalism and Marxism. Held is an open-minded critic of the libertarian thinkers Robert Nozick and F.A. Hayek, specifically in their suggestions that the freer the market, the freer the people within those markets will necessarily be. Additionally, Held rejects their view that the proper role of government is to, as unintrusively as possible, create, protect, and expand markets globally. His basis of disagreement with Hayek and Nozick is principally based on the rank failure of the freest markets in human history to avoid destructive market failures and incur massive social and ecological damage, typically leaving the previously worst off, either worse off or at least still the worst off $(1995,249)$. In other words, they impose externalities. While a right 
libertarian or neoliberal may disagree with Held's critique here, they would likely find little disagreement with his descriptive summaries of their respective beliefs. The disagreement would come down to normative and empirical evaluations of the various successes and failures of free markets.

The same would not be true for Held's characterization of Marx and the Marxist tradition more broadly. Though Held is correct that Marxists generally reject the liberal state — especially alongside a capitalist market economy — as being an adequate forum for the full realization of equality and freedom (i.e., full, human emancipation), it is not the "systematic inequality" which Held gives so much emphasis that Marxists oppose. It is much more the "massive restrictions on 'real' freedom" which Held does mention and gives only minimal credence too. When Held discusses these "massive restrictions on 'real' freedom" he is still actually talking about the consequential inequalities that prevent a person from being a more fully autonomous participant in the civic culture of a democratic polity. This is where he locates the central problem of capitalism (or what he conflates with and ambiguously refers to as markets or a market economy).

It is true that Marx and Marxists believe the liberal state is basically the puppet of the interests of the economically-dominant class, but many Marxists would reject Held's categorical dismissal of Marxism on the premise that within the Marxist ideal postcapitalist society there is no place for politics $(1995,12-13)$. Held even goes as far as to assert a theoretical connection between the socioeconomic system of the Soviet Union and the one only vaguely hinted at by the later Marx (14-15). In truth, there is very little connection, at least when it comes to judging the viability and relevance of Marxian 
socialist theory in the context of the late twentieth and early twenty-first centuries ${ }^{29}$ Held, in all his discussions of Marxism, libertarianism, and the global economy, never once offers any definition of capitalism (though he does on numerous occasions conflate capitalism with a market economy). The only distinction he does make is in the historical development of capitalism between "capitalist market relations" and "industrial capitalism involving highly distinct class relations" (62). The distinction between the two is asserted, minimally explained and seemingly ignored throughout the rest of Held's major work. This neglect will be addressed more comprehensively in chapters two and three.

To be fair to Held, though, regardless of his (1987) book detailing the theoretical development of the Frankfurt School Critical Theory, he is not a Marxist so we wouldn't necessarily expect him to take utilize Marxian definitions. Held is not even a socialist (though I will later argue that he - and all cosmopolitans - really should be). However, he is also not a libertarian, yet he tacitly assumes their definition as universal — namely the foundational aspect of capitalism is the existence of markets. He believes that markets when properly regulated by democratically responsive governmental institutions are the most efficient way to promote cosmopolitan justice and civilizational progress. Held does not convey any real enthusiasm for this conclusion, but it is the one he leads himself to (241-247).

Held goes on to claim "[c]apitalism is not a single homogenous system the world over; there are different capitalisms with different capacities for reform and adaptation" (249) ${ }^{30}$ He even goes as far to assert his support for capitalism and profit-seeking stating,

\footnotetext{
${ }^{29}$ See Terry Eagleton's Why Marx Was Right (2011).

30 The argument for multiple forms of capitalism or capitalisms, is one that J.K. Gibson-Graham (2006a; 2006b) (Whose post-structural Marxist-feminism will be addressed in chapter four) emphasizes as a
} 
"governments must take action to help secure the profitability and prosperity of the private sector....A government's policies must, thereby, follow a political agenda that is at last favourable to, that is, biased towards, the development of the system of private enterprise and corporate power" (247). According to his own theory, though, Held argues that restrictions on free enterprise can and must be made - to whatever extent is necessarywhen "whether intended of unintended [markets] generate damaging externalities...[or threaten] the basic requirements of autonomy..." (250). This overarching point will be central to understanding how capitalism in and of itself undermines Held's cosmopolitan aspirations.

Held's definition of globalization is central to this "autonomy-as-assumption-andgoal" cosmopolitan critique of globalization and the anti/alter reactions to it. In both texts, Held offers a complex understanding of globalization. "First it suggests that many chains of political, economic, and social activity are becoming worldwide in scope. And, secondly, it suggests that there has been an intensification of levels of interaction and interconnectedness within and between states and societies" $(1995,21)$. To him, these changes are both a positive and a negative. Globalization is neither as comprehensive nor as feeble as different scholars of different schools of thought have suggested. For Held, the response must not be opposition to globalization as it offers a truly progressive opportunity to develop the most deeply impoverished areas of the globe. At the same time the response should also not be full-fledged optimism. Globalization has wreaked havoc on global ecosystems and millions, perhaps billions, of people have been left behind or integrated

strategic truth that can be used to undermine all the different kinds of capitalist relations of production. Arturo Escobar (2008) makes similar claims as well. However, what they all under-emphasize is what all of these capitalisms share than indeed makes them all deserving of the label "capitalism." 
into a decreasingly welfare-oriented world economy most ending up in only a marginally better socioeconomic situation, if not a worse one $(2004,34-36) .{ }^{31}$

In Global Covenant (2004) Held provides updated empirical data on the status of globalization as well as articulating a social democratic response and progressive alternative to the dominant neoliberal paradigm represented by the so-called "Washington Consensus," which is principally founded on the neoclassical economic theory of Milton Friedman and the political theory of F.A. Hayek (Hayek [1944] 2007; Friedman [1962] 1982). Held examines and critiques contemporary globalization on three dimensions: economics, politics, and law. The argument here contradicts little if any part of the argument made in Democracy and the Global Order. However, Global Covenant is much more specific about his suggested alternative, as well as the real necessity of such an alternative. Here he offers concrete suggestions for how to reform intergovernmental organizations (IGOs) such as the United Nations (UN), International Monetary Fund (IMF), World Trade Organization (WTO), and World Bank. The reforms are based on altering the goals and practices of these organizations so that they are more democratically responsive and aimed at promoting human development across all strata of populations, not just representing the interests of the OECD states or transnational economic elites. The economic goal is to provide sustainable development through a mixture of properly regulated global markets and public funding for the basic necessity of even the most minimally prosperous human existence (e.g., food, water, shelter, basic health care, education, livable environments, etc.). The broader political goal is a more robust democratic global political order that does not homogenize preexisting cultures or polities.

${ }^{31}$ Also, see Held and McGrew Globalization/Anti-globalization (2007). 
Held's social democratic alternative maintains the cosmopolitan federalism argued for in his earlier work.

The cosmopolitanism that Held is presenting is one that combines an ethical impetus with institutional entailments that would be minimally necessary to secure the ethical goals. In the appendix of Global Covenant, Held presents the eight cosmopolitan principles that form the core normative basis of his otherwise primarily pragmatic social democratic alternative to the current neoliberal world order: "1. Equal worth and dignity; 2. Active agency; 3. Personal responsibility; 4. Consent; 5. Collective decision-making about public matters through voting procedures; 6. Inclusiveness and subsidiarity; 7. Avoidance of serious harm; [and] 8. Sustainability" (2004, 171-176). It is clear from these principles that Held's cosmopolitanism is normatively pragmatic (meaning there is an ethical necessity to pursue these cosmopolitan values because they are the best practical way to achieve the values we already hold dear, in the age of globalization). Cosmopolitan ideals are necessary responses to an increasingly globalized reality where democracy, autonomy, and equality are already almost universally agreed upon goods. ${ }^{32}$

\section{(2) Critical (Theoretical) Cosmopolitanism: Habermas and the Habermasians}

It would make sense that a school of thought that has deep ties to Marxism and was initially founded as school of neo-Marxism, under the clandestine label "Critical Theory," would result in a contemporary tradition whose representatives would come up with a theory of cosmopolitanism that tackled capitalism and the global economy head on. This section will evaluate precisely this assumption by examining the oeuvre of Jürgen Habermas as well as two representative thinkers who are best known for their novel

\footnotetext{
${ }^{32}$ For further discussion of these ideals see Held's Cosmopolitanism: Ideals and Realities (2010).
} 
applications of his approach towards a rigorous theory of cosmopolitanism within the Frankfurt School tradition, Seyla Benhabib and Andrew Linklater. This section will continue in the vein of the first section, exploring the aporia of deep theorizing about capitalism by cosmopolitans. Even thinkers supposedly inspired by dialectical theory and the critique of capitalism seem to have lost much of this edge, an edge that must be regained if they are to truly deserve the label "Critical Theorists."

\section{Habermas and Lifeworld Cosmopolitanism}

In order to fully understand the development of Habermas's perspective on cosmopolitanism, as well as that of his disciples Benhabib and Linklater, we need to understand Habermas's philosophical sociology and ethics that form the foundation of all three approaches. The first step in Habermas's theory of communicative action/rationality was fully developed in the two-volume tome, Theory of Communicative Action. It is also here where we will find Habermas's fullest explication of the essence of capitalism (though his earlier work in The Structural Transformation of the Public Sphere and Legitimation Crisis discuss capitalism as well). Habermas became even more well-known in the mid 1980s through the early 1990s for his theory of morality, known as discourse ethics, which extends his theories of universal pragmatics and communicative action out of the realm of conventional sociology, linguistics, and psychology—which later itself got extended back into the political and legal realms in Between Facts and Norms, Inclusion of the Other, and The Postnational Constellation.

Discourse ethics is a metaethical theory developed by Habermas and Karl-Otto Apel based on a reformulation of Immanuel Kant's deontological ethics. Discourse ethics is a way to "distinguish the 'good'.... which is always context specific and may take a 
plurality of forms, from the 'right', which must take the form of universalizable principles. The right helps us determine what kinds of versions of the good life are morally permissible" (Hutchings 2010, 43). Habermas moves away from the monological determination of ethical and moral principles to one based on dialogue, on actual communication between people. This is precisely the move away from Kant's individually and transcendentally justified categorical imperative of universalizability to Habermas's categorical imperative. The claim is that actual practices of communication and argumentation between people are imbricated with assumptions and norms that are necessary, for communication aimed at understanding and collective action to be possible at all. Even the most radical skeptic performatively agrees to abide by these norms simply by offering reasons for their skepticism (44-45).

The basics (and these are extremely simplified) of transcendental pragmatics and the theory of discourse ethics that is based on it are as follows: Two major principles can be derived from the norms inherent in communicative action: “(D) Only those norms can claim to be valid that meet (or could meet) with the approval of all affected in their capacity as participants in a practical discourse" (Habermas 1990b, 66, 121). And “(U) For a norm to be valid, the consequences and side effects that its general observance can be expected to have for the satisfaction of the particular interests of each person affected must be such that all affected can accept them freely" $(65,120)$. "Moral argumentation thus serves to settle conflicts of action by consensual means" (67). There are two guiding principles immanent to discourse ethics and communicative action: 1. Inclusivity 2. NonDomination. ${ }^{33}$ These are immanent and rational, because if a person is using coercion or

\footnotetext{
${ }^{33}$ See the later discussion of the distinction between strategic action and communicative action in the context of capitalism.
} 
some form of external power to compel agreement, the process ceases to be argumentation and becomes something akin to strategic behavior or worse. It would make no sense to say "Ah yes, I have achieved general agreement and consensus to a norm, by force or with the exception of the people I prima facie excluded without providing relevant, substantive justifications for their exclusion" (Apel 1990; Habermas 1990).

In Between Facts and Norms (1998) (and the companion article "Three Normative Models of Democracy" [2002] as well) Habermas develops his discourse theory in a more explicitly political manner in the form of a discourse-theoretical model of democracy (and law). The goal of this model is to suggest a framework for democracy that "contain[s] precisely the basic rights that citizens must mutually grant one another if they want to legitimately regulate their life in common by means of positive law" $(1998,118)$. This discourse theory of (deliberative) democracy is a middle-ground between conventional liberal and republican understandings of freedom and popular sovereignty. According to Habermas, it draws from the strengths of each theoretical tradition. "In agreement with republicanism, it gives center stage to the process of political opinion- and will- formation, but without understanding the constitution as something secondary..." but instead discourse-theoretical democracy views constitutions as the persistent mechanism to construct the forums for communicative action and public deliberation which in turn produce a:

Discourse theory...[which] insists on the fact that democratic willformation does not draw its legitimating force from the prior convergence of settled ethical convictions. Rather, the source of legitimacy includes, on the one hand, the communicative presuppositions that allow the better arguments to come into play in various forms of deliberation and, on the other, procedures that secure fair bargaining conditions. (1998, 278-279; 298) 
However, it is not just through institutions that constitutions play an important role in consensus reaching in public deliberation. The public sphere is something that Habermas mobilizes in his theory to connect the people to one another and the people to the governmental decision-makers in both formal and informal ways. It is through constitutionalized principles that promote a fully functioning, ever-expanding public sphere that is more accessible than the conventional nodes of political decision-making (1998, 308-309). In summation, for Habermas, deliberative democracy "relies precisely on those conditions of communication under which the political process can be presumed to produce rational results because it operates deliberatively at all levels" ([1998] 2002). The public sphere allows for a compromise theory between liberal and republican sovereignty where individual and collective wills are co-created and co-exercised through a healthy public sphere and public law.

In early work that engaged with the potential of cosmopolitan extensions of his discourse-theoretic model of democracy in The Postnational Constellation (1998), Habermas was much more skeptical of the necessity and even possibility of such an application. He developed a very minimally cosmopolitan theory based on the idea of global domestic policy. Global domestic policy would cover the few areas of truly global concern or topic areas which there is also already enough relevant intersubjective communication about, and to such a degree that there could be some semblance of an existing transnational public sphere capable of (re)producing a minimal intersubjective will formation that would give any global policy, arrived at through IGOs and nation-state governments, the potential for legitimacy (83-100). At that point, Habermas believed "on the global level, however, both the competence for political actions of a world government 
[or something similar] and a corresponding basis for legitimation are lacking" (105). Though even around the time this was written Habermas believed that nation-state legitimacy could be based on the contestation and democratic internalization of human rights norms $(2002,211-212)$. This last point remains true in his most recent work (2012, 95).

With regard to the potential for a legitimate transnational political governance, Habermas has been optimistic (while also being critical). The implications of the successes and failures of the European Union (EU) have been his focus for well-over a decade now. He recently concluded that because of what we have witnessed in Europe (namely the progress, however contested, of the EU), a cosmopolitan world community is now possible and necessarily, though it will need to be progressively developed over time. The key elements of such a transition would the creation of a world parliament alongside a reformed UN. In this regard, his position is closer to David Held's than Benhabib's or Linklater's (2012, 58-67).

Capitalism is a much more complex topic for Habermas. There is much less discussion of it in his more recent work, but it was a major concern especially before the 1990s. He spent a great deal of time and effort discussing the dynamics of advanced capitalism, but he never provides a clear definition of capitalism, beyond his critique of historical materialism and Marx more broadly. The basis of this critique is that Marx unjustifiably focuses on manual labor and class conflict in his depiction of the evolution of the modes of production. Instead, for Habermas, all kinds of social labor and communicative interactions aimed at solving social problems are the actual engine of historical change and societal evolution (Habermas 1979; 1989; McCarthy 1981). In his 
most positively anti-Marxist conclusion he argues that the social welfare state "pacifies class conflict" (Habermas 1979, 343).

More related to his understanding of cosmopolitanism, we come to Habermas's well-known thesis on the colonization of the life-world (by systemic logic). This distinction between lifeworld and system allows for the possibility of communicative action, discourse ethics, and eventually discourse-theoretical democracy. Lifeworlds contain the shared background cultures and norms of a society, everything that isn't part of the systems. Systems include governmental bureaucracies or administrative bodies, and the economy. These systems operate under technical rationality and strategic action where the principles of tactical compromise and competition reign. Each system has its own specific logic that is peculiar to the respective system. Society functions smoothly when lifeworld and systems remain under the aegis of distinct logics, and in order for the emancipatory potential of the lifeworld to be maintained, it must remain grounded in the logic of communicative action guided by "the force of the better argument" in a coercion-free public discourse including all relevant parties (Habermas 1990, 58, 90, 109, 128-135). Under a capitalist economic system there can often be threats that the logics of the systems will come to dominate the lifeworld. In liberal democracies this means the eschewing of the radical potentiality of communicative rationality and action (Habermas 1975; 1979; 1989; 1998; McCarthy 1981). This is a threat, not an empirical or intrinsic fact, and it is one that is not directly connected to any necessary characteristics of the capitalist mode of production; instead it is a contingent social potentiality of modernity (Habermas 1989, 334$357)$. 
In Habermas's later work including The Divided West (2006) and The Crisis of the European Union (2012) there has been a defiant critique of neoliberalism, favoring instead a return to the more favorably social-democratic embedded liberalism of the early to midtwentieth century. Under this kind of welfare state regulated capitalist market economy, money and bureaucratic power are potentially positive mechanisms of social integration, always "anchored via legal institutionalization in orders of the lifeworld, which are in turn socially integrated through communicative action" (1996, 39-40). They are systems "anchored" by the lifeworld and "social solidarity" controlled and legitimated through constitutional self-determining processes $(40-41 ; 373-374)$. This is the legal-legitimizing function of public spheres. And due to the open, contingent nature of public spheres, there is always "potential for self-transformation" leading to increasing inclusiveness (as was the case for bourgeois public spheres in the nineteenth century regarding laborers and women (374). Based on Habermas's argument, we are left with the conclusion that neoliberalism undermines this process but capitalism itself does not (2006, 180-187).

Contra Marx, Habermas (1989) does not see any theoretical cogency to the concept of alienation, but if there were he still doesn't believe that this is something inherent to modern capitalism. Rather, even if capitalism did allow for, or in instances cause, alienation, it also provides the opportunity for productive individuation, one of the most important dimensions of modern democratic freedom. The feasibility of such a cosmopolitan move is subject to empirical investigation and implementation. This means that the feasibility of his cosmopolitanism rests on whether there can be and actually are transitional publics where intersubjective will-formation can take place through communicative actions under a globalizing capitalist world order. 
Habermas's understanding of capitalism in the context of cosmopolitanism moves little past this critique of neoliberalism and the arguments made in his earlier work discussed above. The primary theoretical consistency between Habermas's political philosophy at the domestic level and cosmopolitanism is his theory of communicative action, which is the basis of his above described discourse ethics, including his distinction between lifeworld and system extending to the underlying threat of the colonization of the lifeworld.

Applied through public spheres across national boundaries connected to the international political institutions like the European Union and United Nations as well as NGOs, the importance of discourse ethics can speak to the possibility for the legitimation of society and politics with a cosmopolitan character in this fashion through an increasingly inclusive and enforced set of basic human rights (Habermas 2013, 95).

Under modern conditions of life none of the various rival traditions can claim prima facie general validity any longer. Even in answering questions concerning questions of direct practical relevance, convincing reasons can no longer appeal to the authority of unquestioned traditions. If we do not want to settle questions concerning the normative regulation of our everyday coexistence by open or covert force-by coercion, influence, or the power of the stronger interest - but by the unforced conviction of a rationally motivated agreement, then we must concentrate on those questions that are amenable to impartial judgment...we must ask what is equally good for all....in other words questions of justice. (1994, 151)

Habermasian cosmopolitanism involves his limited extension of the theory of communicative action and the public sphere to the transnational space through his notion of "global domestic policy" (1998; 2013). Truly though, there is no single Habermasian conception of cosmopolitanism. As it has always been for his theoretical work, Habermas's approach to this topic is constantly being restated and rearticulated with adjustments of 
substance and emphasis. It is thus difficult to pin him down to a particular vision of cosmopolitanism. The next two thinkers I discuss, Andrew Linklater and Seyla Benhabib, are ones who have attempted to apply Habermasian theory to construct a more coherent and concrete proposal.

\section{E. Benhabib and the Cosmopolitan Right to Hospitality}

Benhabib's interpretation of discourse ethics is one that is sensitive to postmodern feminist interpretations of culture, community and individual identity formation. In her words, the discourse principle of legitimacy based on discourse ethics is the idea that "all those who are affected by the consequences of the adoption of a norm have a say in its articulation" (Benhabib 2004, 218). This discourse principle of legitimacy provides the philosophical basis for the solution of the democratic paradox and the problem of the right to have rights. ${ }^{34}$ However, Benhabib's work goes deeper beyond conventional neoKantianism. For her, discourse ethics is sensitive to the "concrete other," not simply the "generalized other" central to John Rawls's theory of justice derived from the Original Position and veil of ignorance (Benhabib 1987, 1992; Rawls 1971). What this means is that for Benhabib, discourse ethics is constituted by the recognition that what matters is not some abstract conception of a person or human being that we can imagine, but rather that were are all "concrete others" with a concrete individual and social "history, identity, and affective-emotional constitution..."(Benhabib 1987, 92; 1992, 164). This is latent in

\footnotetext{
${ }^{34}$ The democratic paradox (or the paradox of democratic legitimacy, as Benhabib refers to it) is the contradiction between the universalistic audience of liberal rights discourse and the particularistic nature of democracy. More concretely, for Benhabib this means that "the people" (the demos) excludes others from participating in the decision of who should be allowed to be a(n initial) member of the demos - the demos which will then decide future questions inclusively and democratically but within the bounded group that was not itself determined inclusively (Benhabib 2004; 2011).
} 
Habermas's original conception of discourse ethics and should not be viewed as criticism so much as a moment of reemphasis:

We seek to comprehend the needs of others, his or her motivations, what $\mathrm{s} /$ he searches for, and what $\mathrm{s} / \mathrm{he}$ desire. Our relations to the other is governed by the norms of equity and complementary reciprocity: each is entitled to expect and to assume from the other forms of behavior through which the other feels recognized and confirmed as a concrete, individual being with specific needs, talents and capacities. Our differences in this case complement rather than exclude one another. (Benhabib 1987, 87)

Benhabib takes Habermasian theory as her foundation and combines it more explicitly with Kant's notion of cosmopolitan right in the form of a right to hospitality. This is a strictly legal right to cultural and political respect due to any person, but especially those who were under threat of violence or persecution in their previous place of residence. The end goal of the legal enforcement of such a right would result in (or be the result ofBenhabib is not exactly clear) a kind of cosmopolitan federalism, akin to what is suggested by both Pogge and Held and more recently even Habermas himself. The exigencies of the global marketplace are a concern of Benhabib, especially in how they determine or shape our capacities to participate in coercion-free discourse and public spheres in service of democratic legitimation (as is under-emphasized in Habermas). For example, if I have to teach five classes a day as an adjunct professor to pay my rent or say I am a single mom with several kids and need to work eighteen hour days to put food on the table (and say, pay for a table), what kind of time and effort will realistically remain for me to effectively participate in the lifeworld, public sphere, or processes of democratic iteration and legitimation? We are left with an almost identical conclusion that Habermas gave as early as 1979 (though in a domestic context): the social-welfare state is necessary for democracy and justice. For Benhabib, the importance of the social welfare state in the context of 
cosmopolitanism needs to be addressed, though even in her most recent work the focus remains on the cultural-political intersections within transnational public spheres.

The argument later provided by Linklater (1998), incorporating Benhabib's thinking, is that a praxeological account of discourse ethics at the global level must illuminate the socio-economic barriers to achieving the ideal communication community, including income and resource inequality but also socially constructed gender norms. Without ways to mitigate these disparities, the ideal communication community in which discourse ethics could structure institutions and global arrangements will forever be a distant dream. Linklater believes that there have been and will continue to be important efforts to address the necessary preconditions of discourse ethics and thus dialogic communities will continue to become more and more realizable. Those people who disagree with any aspect "can challenge the principle of universal moral respect and egalitarian reciprocity within the moral conversation, but if they want to establish that their position is right not simply because it is mighty, they must convince with argument that this is so" (Benhabib 1990, 340).

This point is made more vaguely by Linklater (1998), but more emphatically and pointedly by Benhabib (1990; 1993; 2004). Benhabib has her own critiques of discourse ethics that she made prior to Linklater's seminal text, so he included them in his own argument, instead of basing it entirely on Habermas's work. ${ }^{35}$ Her main problem, and it is a perspective held by other feminist thinkers as well, is that discourse ethics does not deal with the disparities present in social relations prior to the ideal dialogue occurring and therefore maintains and preserves patriarchal domination of political life. This criticism is

\footnotetext{
${ }^{35}$ See Benhabib, Feminism as Critique (1987) and Situating the Self (1992).
} 
fair and relevant, which is precisely why Linklater saw the need to explicitly address it. Neither he nor Benhabib sees this critique as undermining discourse ethical theory but rather quite the opposite. They both argue that discourse ethical theory needs to be more clear about the necessary preconditions required to reach the ideal communication situation, which includes the restructuring of socioeconomic relations so that true domination- and power-free communication is achievable. We can see this as a commentary on the inequalities generated by global capitalism and markets, which both Linklater and Benhabib refer to, but neither one takes this deeper than a facile semiconsequentialism in the service of Habermasian deontology.

F. Linklater and the Mitigation of Harm through Cosmopolitan Dialogic Communities

Andrew Linklater provides us with the first major attempt at applying Habermasian discourse ethics to international relations and international relations theory. The key text in this project is The Transformation of Political Community (1998). The general purpose of this book was to "... reaffirm the cosmopolitan critique of the sovereign state system and to defend the widening of the moral boundaries of political communities" (2). Linklater isolates the inclusion/exclusion dichotomy as the central axis of contemporary normative international relations scholarship and it is this axis where he justifies his attempt to transcend the modern Westphalian state system through the explication of a globalized discursive ethical praxeological theory. His approach is praxeological in that it approaches theoretical-sociological inquiry by searching for the seeds of novel forms of political organization within the extant structures, in "existing forms of life and anticipated by their moral reserves." It is praxeological in another sense as well, in that it looks to isolate the 
aspects of existing forms of socio-political community that function as road-blocks toward the achievement of new, more emancipatory forms of community (5).

Linklater explains "[d]ialogic cosmopolitanism...make[s] it possible for ethical universalism to "be reawakened and further developed in the form of multiculturalism"” (Linklater 1998, 88). How to accomplish this is left mostly underdeveloped, but it must draw on the modern ideals of constitutionalism, extending democratic possibilities, and the evolution of more nuanced perspectives towards the social and economic necessities prior to the formation of true dialogic communities (169). The solution for Linklater (1998), borrowing from E.H Carr and others, is a post-Westphalian understanding of the state and citizenship. The achievement of this kind of global political system is found in transnationalizing discursive ethical principles: inclusivity and domination- and powerfree communication between all peoples, societies, and nations. "All that has to be assumed is that cultural differences are no barrier to equal rights of participation within a dialogic community" (85). Citing Habermas, Linklater goes on to describe how the principles of discourse ethics hold the greatest promise of institutionalizing liberal cosmopolitan goals in ways that alternative world-views will not be oppressed by or find inherently disagreeable.

Linklater's most recent (and announced future projects) focus on the problem of harm in a cosmopolitan context. The basic argument here is that over the development of modern civilization there have been increasing potent and influential (cosmopolitan) norms against causing undue harm to others. The development of these "harm conventions"embodied in religious doctrine, social practice, and more recently in international laware part of "civilizing processes," an idea first conceived by Norbert Elias, on whom 
Linklater draws heavily $(2011,244)$. In the context of this chapter, it is important to see how Linklater characterizes harm in the context of capitalism. As we have seen with the previous five theorists, Linklater discusses harm in this context as structural complicity (as in Pogge) and as a direct outcome of exploitative and inhumane laboring conditions (5355). Linklater, regardless of how much implicit support for what he describes he might be aiming to express through his exposition of the various possible and actual historical conceptions of harm, it remains just that - an exposition. His most favorable statements tend to critique the material consequences of capitalism, namely inequality in the form of extreme poverty. Linklater continues his argument in the liberal tradition. Since John Stuart Mill and John Locke before him, causing undue harm to another person violated a central tenet of liberalism, and Linklater claims, similar to the classical Marxian critique, this is a dimension of liberalism that has yet to be even minimally realized in practice.

The Problem of Harm in World Politics (2011) concludes with a discussion of the relationship between the extant structure of the nation-state system, continuing his earlier work, here in the dual contexts of the perpetuation of as well as the potential mitigation of global harms. Cosmopolitan harm conventions as part of a "global civilizing process" may well serve as one of the most likely avenues for the progressive transformation of the global political community towards a more structurally just ordering (152-153, 185-189). In the end, there is a broad lack of engagement with capitalism in relation to the overall thesis of cosmopolitan harm conventions and the potential for a global civilizing process even as Linklater maintains his ties towards the goals of achieving a discursively-ethical world system. 


\section{(3) "Radical" Cosmopolitanisms}

\section{G. Ingram and Cosmopolitanism as Radical Democratization}

Contrary to Beitz's, Pogge's, and Held's views that moral cosmopolitanism does not necessarily imply a specific political project, James Ingram suggests that it is a false dichotomy to separate the ethics and politics of cosmopolitanism at all. This is not an empirical claim. Ingram is not suggesting that all cosmopolitan theorists have a specific political project, but rather that the ideals of cosmopolitanism by their very nature imply a certain perspective on politics. Similar to Pogge's claim that the moral responsibility entailed by the negative duty not to cause or perpetuate a social system which induces undue harm leads to the practical requirement that if we find ourselves in such a situation (as we currently do in both Ingram's and Pogge's views), Ingram argues that ethical cosmopolitanism, in all its forms, necessarily entails a political project (102). This intersection between ethics and politics in regard to cosmopolitanism is rooted deeply in Kant (104). The problem Ingram sees in Kant and those described in this chapter broadly working within his legacy, is that:

[at] the same time that Kant prescribes a just and inclusive cosmopolitan order, he proscribes the very steps by which he imagines it might come about.... While they [the inheritors of Kant's approach] articulate an attractive alternative to the current global order, they are unable to account for how it might be achieved. (105)

Ingram offers his own conception of how that could be achieved-a radical cosmopolitanization of democratization.

Ingram's conception of cosmopolitan universalism is one of agonistic democratization, or in his terminology a "radical cosmopolitics." Specifically pragmatic in the context of human rights, cosmopolitanism is here best understood as a discourse of 
struggle for more expansive and inclusive political institutions and policies. In this sense, ceaselessly expanding democratic cosmopolitics is the means and end of cosmopolitanism in its most theoretically sophisticated and practical incarnation. Consensus and completion are always on the horizon, and there is always more critique and self-reflection to be done. Even when cosmopolitics becomes more and more inclusive, there will always be hierarchies and exclusions. Despite Ingram's scathing critiques of existing universalist cosmopolitan theories for their tendencies to disguise injustice under the cloak of justice (a point he primarily levels at Rawls but extends to Habermas and Rainer Forst [2012]) he still values the normative practicality of universalist contestation. " $[\mathrm{H}]$ ow could we object to and oppose these new forms of domination except on some kind of universalistic basis? Even if the promise of universalism is eternally condemned to betray itself, there is no way to oppose these betrayals aside from ever-new appeals to the universal" (149). Thus his critique of cosmopolitanism and supplement of radical cosmopolitics is radical in the agonistic sense of Laclau, Mouffe, and Ranciere - though with much less of a critique of capitalism (or even explicit discussion than we find in these more domestically-oriented radical socialist theorists).

Ingram's take on capitalism is complicated and underwhelming for a theory that labels itself "radical." It is vague and unspecific with regard to the relationship between capitalism and radical democratic progress. Ingram is extremely critical of Habermas's and James Bohman's (2007) (among others') overly sanguine view of the democratic and egalitarian potentials of public spheres at this point in history, "On the one hand, the rich have far more access than the poor, the educated more than the uneducated....the specificities of the global public sphere...can only exacerbate these tendencies" (2013, 
139). In other words, the elitist and inegalitarian nature of the public spheres undermines any democratic potentials it may have. However, Ingram fails to locate the failure of public sphere in the system of capitalism itself, something which Habermas's "colonization of the life world" thesis has the potential to. Ingram's focus, based on Bourdieu's critique of the historical yet contingent reproduction of inequalities throughout all levels of social, political, cultural, and of course economic capital, is on exclusion (seen in his dense discussion on the right to have rights), (in)equalities and domination (179).

Even after his very thoughtful textual exegeses on Pierre Bourdieu and Judith Butler, I am left wondering: where is the argument for why the injustices of capitalism are just viewed as merely another set of injustices and inequalities alongside other injustices and inequalities, as opposed to being in the last instance (over)determinant of these other injustices (e.g., racism, sexism, ageism, etc.)? Broad versions of such an argument have often been made by radical leftists since Marx up through Althusser. Ingram does not address such a claim. He does not address the relationship between cosmopolitanism—or cosmopolitics - and capitalism, beyond the typical invocation of Marx's and Engels' quip on the cosmopolitanization of capital. It is left to the reader to infer that capitalism, as a totalizing (even universalizing system—which is something a book so heavily focused on the idea of "universality" should probably address more explicitly) is a system of inequality and domination, though complicatedly inclusive and exclusive in different ways. Again, even this last connection is left to the (leftist) reader to make. Chapter three will explore how the psycho-social dimension of capitalism more seriously undermines radical cosmopolitics, as well as how we can and must, radicalize Ingram's radical cosmopolitics even further. 
H. Pheng Cheah and the (Ir)Reconciliation of Inhumanity with Cosmopolitan Progress:

"In the end, there can be only one." This is a truism that seems to apply to cosmopolitan theorists as well as Highlanders when it comes to making a full-frontal assault against capitalism. ${ }^{36}$ Pheng Cheah is the Highlander of cosmopolitan critiques of capitalism. Cheah's quasi-post-colonial emancipatory critique and reformulation of postcolonial nationalist cosmopolitanism centers around his critique of the centrality of the relationship between cosmopolitanism and global capitalism. This postcolonial nationalism represents a rejection of the imperial imposition of European nationalism, and thus the inadequacy of that traditional conception of nationalism for the former colonial states $(2006,18)$.

The postcolonial nation(-state) and the popular movements that it enables and which create it, through its relation to the cosmopolitical realm - itself enabled by historical globalizing capitalism— has the potential to serve a similar function that the bourgeoisie served in seventeenth and eighteenth century Europe in the transition from feudalism to capitalism. It was a revolutionary class. It is no longer. For Cheah, this never guaranteed potential lies with the postcolonial nation, always in conjunction with transnational forces, including MNCs, NGOs, and IGOs regardless of and through their inhuman practices and

\footnotetext{
${ }^{36}$ This is meant as a joke but a pointed purposeful one. In the film Highlander, there can only be one immortal super-powerful entity known as Highlander. If there are two, they must battle to the death. Though there is no such prohibition on multiple cosmopolitan theorists sharply criticizing capitalism, in my reading, I have only come across this one. Unless Pheng Cheah is the Highlander of cosmopolitanism, I see no reason why such a critique (or even thorough understanding) of capitalism should be such a minority position within the literature. Though as I will explain, there is good reason to consider a number of postMarxist thinkers like Balibar and Hardt and Negri cosmopolitans of sorts, and Cheah's placement in this literature is complicated by his embrace of a kind of post-colonial nationalism (though it is admitted more of a pragmatic position than a moral or ethical one).
} 
policies. His approach is hopeful but not optimistic. A cosmopolitanism advocated by the likes of Held or Pogge or even Habermas and the Habermasians shortchanges the reliance of the modern welfare state on the exploitation of the Global south. According to Cheah, this model of transnationalizing existing Western models of redistributive justice and democratic politics fail because they cannot account for their own dependency on exploitative global capitalism (73). He tells us "[t]he emancipatory potential of these new cosmopolitanisms turns on the nature of their relation to capitalist globalization" (20). Though Cheah would agree with Habermas's view that the emancipatory potential (democratic potential) of the public spheres is contaminated by its relations to capitalism, regardless of whether those bourgeois rights and liberties including the notion of equality are core elements that should be drawn on in with a kind of cosmopolitanism that is vociferously anti-capitalist. He writes, "The feasibility of Habermas's model is premised on the existence of globalizing processes that are autonomous from the logic of capitalist accumulation. But this premise is questionable" (60). Habermas equally fails to acknowledge the internationalization of competition in relation to the formation of a more transnational lifeworld (69).

More broadly speaking, Cheah rejects two important influences on Habermas. He rejects Kant's reliance on globalizing capitalism as a source of cosmopolitan right and republican world federalism as well as Marx's argument that nationalism is an ideology of the early stages of capitalism meant to be overcome by the cosmopolitan (universal) character of the proletariat (22-29). The relationship between cosmopolitan values at their best with capitalism is precisely how Cheah formulates his overarching philosophical thesis that inhumanity is essential in the formation humanity (both as a fact and goal). 
How then does Cheah's postcolonial cosmopolitical nationalism reconcile the exploitative inhumanity that forms the core of even the more radical conceptions of cosmopolitanism? The short answer is that it doesn't. This is "the given." This dialectical incompatibility of inhumanity and cosmopolitanism needs to be accepted. The use of the word "accepted" here, it is important to note that this does not mean we should not vigorously oppose the exploitation inherent in the realist and neoliberal international political economy of global capitalism, but instead accept here means to take this as a given. What do we do with this inescapable fact that inhumanity forms a central historical dimension of our current capacity to expand the bounds of humanity? In a similar vein that Marx and Ingram suggest, we need to enable resistances at the national level, with cosmopolitical cooperation (or international solidarity to use a more technical phrasing).

To comprehend the possibility of the national-in-thecosmopolitical—and I use this awkward phrase to indicate a condition of globality that is still short of mass-based cosmopolitan consciousness - we need to understand postcolonial national culture in terms other than as an immutable natural substrate or as an ideological form imposed from above, a constraint to be transcended by the formation of an emancipatory cosmopolitan consciousness. (95)

Exploitation, suffering, and even death come from the same potential sources as liberty and freedom - a source that will eventually need to be transcended once the objective cultural material conditions are right-bourgeois capitalism, specifically its instrumental technologies. What is interesting given the nationalist perspective he takes on cosmopolitanism at this point in history, Cheah favors an emancipatory world state “capable of ensuring an equitable international political and economic order" $(2006,105)$. This possibility, this necessity, is still too far away to be worth seriously considering in his view. Cheah believes, in a vein similar to Kant's, Arendt's and Fraser's fears of a 
globalized tyranny, that if such a world state were to be attempted today, it is much more likely to be equally as exploitative as the existing neoliberal order dominated by the Global north. Everyday emancipatory struggles against the inhuman conditions of globalized capitalism are where the emancipatory struggle is being waged right now, and this is where the focus of cosmopolitan intellectual resources should be (109; 115-119). Recognition of this site of struggle and its broader cosmopolitical connection with global capital contingently opens up the historical possibility for a more fully realized notion of humanity (264-266).

Cheah remains the only theorist I have come across who values the language and potentiality of human rights and cosmopolitan ideals without attempting to separate them from the inhumanity, exploitation, and historical suffering that has allowed these progressive principles to emerge in the first place. Though I believe classifying Cheah as a cosmopolitan is a problematic undertaking due to his emphasis on the nation-state as the most important emancipatory site, I believe it is still a kind of cosmopolitanism akin to the cosmopolitan realism of more liberal cosmopolitan thinkers like Ulrich Beck $(2006,2008)$ and Richard Beardsworth (2011), both of which assert the enduring relevance of the nationstate. Though the general comparison to cosmopolitan realism is apt, Cheah's cosmopolitan realist elements more adequately address the seriousness of the intrinsic harms incurred by the very nature of (global) capitalism. Through the coming discussion of the capitalistic mentality in chapter two and the critical potential of that concept in the context of cosmopolitanism, I want to speak directly to the minimal remaining issues and incompleteness that I believe remain even in Cheah's postcolonial cosmopolitan nationalism. 


\section{Conclusion}

Given that there is such a diversity of theories of cosmopolitanism, it is difficult to avoid reifying the label cosmopolitanism while at the same time saying anything coherent about it as a whole. So then what do these various approaches tell us about the core characteristics of cosmopolitanism? The answer may not hold true for every version, but cosmopolitanism in general has several important components, and it is these components, in this broader understanding of cosmopolitanism, that will be progressively shown throughout the next three chapters to be dialectically-produced historically by the expansionist logic of industrial capitalism and now stalled by globalizing industrial-turnedconsumer capitalism:

1. Our basic worth as human beings, extending to a desert for basic political, social, and economic rights or - at least the content goals of those rights - is not ethically restricted or shaped by regional, nation-state, or even more local boundaries. In other words, cosmopolitanism requires that all people be protected by a set of context-sensitive basic human rights. ${ }^{37}$

a. The corollary to these rights is that there is an obligation to not violate them in addition to working towards their achievement, both structurally and in specific instances of known violations.

2. The determination of those basic human rights as well as any additional laws or policies at any level of governance should include all those people who are likely to be affected (or who are in practice affected) in a coercion free discourse

\footnotetext{
${ }^{37}$ Context-sensitive here means that the rights themselves are viewed as broadly universal, but how the obligations they create are met is a matter for more localized interpretation and reinterpretation.
} 
a. The corollary to these rights is that there is an obligation to aim to secure the socioeconomic conditions necessary for adequate participation by all those who should be included. This includes a duty to accept outsiders, even if only temporarily, if their current existential situation is in violation of the first or second principles (i.e., a right to hospitality).

3. Democratization and human rights include institutionalization but are also embodied in the everyday struggles by those who are worst off. Democratization is the core of cosmopolitan universalism and is an always incomplete process that is undermined by exploitative socioeconomic systems and practices which cause undue harm (including structural racism, sexism, exploitative labor, and lack of socioeconomic opportunity).

These principles, to varying degrees of explicitness, are represented in the most advanced and novel theoretical explorations and critiques of the cosmopolitan tradition offered by Beitz, Pogge, Held, Benhabib, Linklater, Ingram and Cheah (though less so in the latter). These last two works are the tradition is at its most thorough, aggressive, and reflective of the lived realities of those struggling for justice (and/or living within the structures of injustice) - though they are still incomplete (and not merely incomplete in the inherent manner which Ingram and to some degree Cheah suggest any conception of cosmopolitanism will always be-though in that way as well). Even these post-colonial and radical cosmopolitanisms they offer, even when combined with one another, still miss a substantial dimension of capitalism. They miss the negating effect the psycho-sociality of capitalism has on the possibilities for a cosmopolitan progress that is truly democratic and non-exploitative (the ostensible goals of Benhabib and Linklater and explicitly of Ingram and Cheah). 
Cosmopolitan realists like Ulrich Beck (2006) and Richard Beardsworth (2011) have argued that cosmopolitans should not look too far beyond the real issues facing the world or too far beyond the existing realities of the global order (which means a substantial acquiescence to what is likely to be politically possible with respect to the range of apparently legitimate policy options). In the case of Beardsworth, he argues further that we must call on leaders to take responsibility for and towards the real problems we face inspired by all the various argument made by the thinkers discussed in the previous chapters. ${ }^{38}$ This emphasis on political reality is an ethical disposition towards the world that is desperately needed to ensure more just cosmopolitan progress, and we have good reason to take their view deadly seriously. A truly realistic cosmopolitanism informed broadly by the principles outlined about is hard for me to imagine while working with an inadequate understanding of one of the most integral forces shaping our present and future, namely global capitalism. More specifically, we need to examine precisely this reality of capitalism which undermines the principles these cosmopolitan thinkers hold so very dear.

\footnotetext{
${ }^{38}$ Beardsworth places his argument more within the theoretical republican tradition (of Phillip Petit) as opposed to the democratic alternatives that will be emphasized here.
} 


\section{CHAPTER 2}

\section{The Capitalistic Mentality: Social Psychology between Base and Superstructure}

"The research to be reported in this volume was guided by the following major hypothesis: that the political, economic, and social convictions of an individual often form a broad and coherent pattern, as if bound together by a "mentality" or "spirit," and that this pattern is an expression of deep-lying trends in his personality." (opening lines of The Authoritarian Personality, 1950)

\section{Introduction: The Concept of Mentality}

Thus far I have laid the foundation for my claim that cosmopolitanism has a contradictory relationship to capitalism, based on the limited understanding and/or appreciation of capitalism common to cosmopolitanism in general. The previous chapter showed how some of the major theorists of different schools of ethical and political cosmopolitanism have attempted to grabble with capitalism or at the very least the increased globalization of (self-described) market economics. This chapter will deal with the other dimension of this thesis: the essence of capitalism. Here I will argue that there is an intrinsic psycho-social facet to capitalism, what I call the "capitalistic mentality." The capitalistic mentality, I will show, based on the work of Marx, Lukács, Adorno, and Fromm, includes: alienation, commodity fetishism (and increasing commodification in general), identitarian thinking, reification, competitiveness, possessiveness, necrophilia ${ }^{39}$, and hyper-individualism. This conceptualization will serve as the launching pad for my argument which will be more fully developed in the next chapter regarding the external and internal contradictoriness of cosmopolitanism with respect to the understanding of capitalism explicated here.

\footnotetext{
${ }^{39}$ This concept will be explained more later, but it does not refer to being sexually attracted to the dead, but rather (for Fromm) this concept refers to a love or — or over-valuation — of non-living things (i.e., commodities or whatever is "new").
} 
The capitalistic mentality is a concept derived principally from combining the theories of Erich Fromm and Theodor Adorno (including their Marxian and Lukácsian origins), two theorists who have generally been regarded as incompatible, at least within Critical Theory (a tradition that at least Fromm seems to have become excluded from based on the dearth of references to his scholarship among contemporary critical theorists, even those works explicitly in the tradition of the Frankfurt School).$^{40}$ In arguing for a reappreciation of the psycho-social dimension of capitalism I will also be arguing for the enduring importance of Fromm's work to classical and contemporary Critical Theory, as well as how his work can be re-constructed to be complementary to much of Adorno's more well-known philosophical and sociological contributions. The concluding argument in this chapter suggests that the social psychology pre-dominant within a social system, in this case capitalism, speaks to the relationship between aspects of society that are typically considered within the Marxist tradition to be superstructural (e.g. culture, politics, etc.) and those considered part of the base (relations of production, means of production, etc.). More precisely, I will show how the capitalistic mentality serves as an intermediary between base and superstructure, between the economic structures that shape a society and the cultural and political manifestations that result.

This chapter focuses on both the foundational elements of historical capitalism, which always includes latent if not always manifested psycho-social traits, but also the

\footnotetext{
${ }^{40}$ There are plenty of theoretical differences between Adorno and Fromm especially regarding their interpretation of Freud's libido theory, but I suspect that much of their disagreement was personal, exemplified by Adorno at one point referring to Fromm as "a professional Jew" and "sentimental social democrat' (a serious insult to a self-described Marxist like Fromm) (Wiggershaus 1995, 266; Friedman 2014, 60-61).
} 
particular character of those traits under late capitalism. ${ }^{41}$ I agree with many theorists including David Harvey (2007), Fredric Jameson (1992) and Ernest Mandel (1972) who make the point that this more recent stage of capitalism is not discontinuous with previous historical versions of capitalism, but that this new stage is not identical to what came before it either. What is important is that the basic patterns, processes, and logics of capital have remained largely consistent. This is a claim that has been thoroughly researched and detailed elsewhere, and functions as a given in this chapter. Where relevant, I will attempt to specify where I am speaking about aspects of capitalism in general and when I am speaking about the particular manifestations of consumer capitalism in Western, postindustrial societies like the United States but such distinctions are often difficult to make and often exceed the parameters of my project. Most of what I will be speaking about is capitalism in general, though my argument need not be generalizable to previous eras of capitalism if any reader finds that trans-historical claim unpalatable. What is centrally important is that, at the very least, capitalism now has this characteristic and function, rooted in the psychological internalization of seemingly innocuous social norms through hegemonic structures of ideology, which increasingly permeate everyday life and ostensibly private experience, all firmly rooted in the fundamental logic of capital(ism).

The argument of this project, rooted in the understanding of capitalism presented here, is that the capitalistic mentality is always present in varying degrees wherever we see capitalism (which is now roughly almost everywhere on Earth). Therefore, redistributive measures will never be enough to make capitalism a workable social system because they

\footnotetext{
${ }^{41}$ The terms late capitalism, consumer capitalism, and neoliberal capitalism are here used more or less interchangeably. The appearance of one label or another is more rhetorical than substantive, as I believe consistent with much of the literature, refer to similar if not the same instantiation of historical capitalism.
} 
leave this mentality intact. This is to say nothing of the point which will be expanded on in the next chapter, that the capitalistic mentality actually undermines progress towards even those limited reforms like redistributive taxation on a more massive scale, leading towards the conclusion that cosmopolitan conceptions of justice and progress require radical structural changes to the dominant socioeconomic practices of the twenty-first century.

Before getting into my analysis of capitalism that is central to my overall project, I want to say a bit more about this concept of mentality in general. For what I will be laying out here I found the various alternative concepts in the Marxist lexicon incomplete or too comprehensive for what I am trying to show, namely the psycho-social mechanism that connects the economic and technological base of society to its ideological, cultural, and political superstructure. I found the concepts of ideology, hegemony, habitus, and doxa insufficient for what I believed Fromm's and Adorno's work were referring to, especially when we look at their work in combination with one another. To put it rather simply, a mentality is a loosely structured, self-reinforcing way of thinking that typically results in certain behaviors. While these behaviors are not present, dominant, or motivational in literally every instance, they are generally normalized, justified, and naturalized. In other words, the generalized pressure for them is ubiquitous and rooted in a particular set of relations of production and consumption. It is not just what is thought, but how it is thought - and more importantly, why it is thought. ${ }^{42}$ When the prior term is added,

\footnotetext{
${ }^{42}$ This point will be the core difference between Fromm's concept of social character and my use of the term mentality. Fromm's concept will be shown later to include what is thought and how one behaves based on the collection of beliefs and ideas. The concept of mentality goes a bit deeper than this, which is where Adorno's philosophy of consciousness and language (negative dialectics) is crucial, though I do believe these are somewhat implicit in Fromm's work. To be sure, the concept of mentality is only meant to be a slight deviation from Fromm's original concept.
} 
capitalistic mentality refers to the particular way of thinking and the behaviors that are typically present and normalized under capitalist systems. ${ }^{43}$

This working definition of mentality should not be understood as a precise concept, but at the same time it is not boundless either. It certainly includes non-mental aspects as well, including conditioned physical responses to stimuli or certain social situations. However, unlike habitus mentality doesn't include an emphasis on physicality or embodiedness. Though our psychologies are always embodied, the embodied aspect is taken for granted in my concept. A mentality is thus narrower than Bourdieu's concepts of habitus and doxa, both of which include dimension that mentality does not (Bourdieu 1977; Rehmann 2013, 231-231). For example, Bourdieu would likely want to look at the physical environment of sports as an embodiment of the competitive aspect of the capitalistic mentality, for example, whereas I simply want to focus on the urge to compete, the psychosocial normalization of competitiveness and its roots in the specific relations of production. It is possible that the difference is more a matter of emphasis than outright disagreement or distinction, but I believe it is an important difference nonetheless.

Mentality is also closely related to the various conceptual incarnations of ideology and hegemony. A mentality can be hegemonic, but it is not necessarily. As with habitus and doxa, mentality is a slightly narrower concept compared to hegemony as defined by Antonio Gramsci or Raymond Williams, who both expanded the concept beyond its original political-economic orientation to include culture as well (Gramsci 1971; Williams

\footnotetext{
${ }^{43}$ Despite its use by Durkheim and the Annals School, the term mentality lacks a relevant historical literature in Marxism or psychology. In these previous uses, mentality is deployed as a stand-in for worldview or personal psychological disposition. While explicated more specifically in a Marxist sense here, my use of the term is generally consistent with these previous non-Marxist uses - though here it is always meant to emphasize the porous, fluid intersection of individual and social psychologies.
} 
1978; 2005).$^{44}$ With that said, the capitalistic mentality is hegemonic in the twenty-first century. It is a product of the dominance and permeation of capitalism into more and more aspect of life and includes the internalization and often unquestioned acceptance of capitalist norms. However, hegemony, defined as a unified and dominant social order (re)produced through mass consent gained by (class) compromise on the part of the ruling interest groups to non-dominant groups in order to maintain not only their acceptance but their support, is a kind of social situation; it is not itself a psychological concept (Bottomore 1983, 230). It is a kind of political-sociological benchmark. The capitalistic mentality could be hegemonic, or if we were transitioning to socialism or regressing to feudalism, it may not be any more. Hegemony requires psychological mechanisms to exist, but conceptually it is not identical to those mechanisms.

In regard to ideology, many if not all of the aspects of the capitalistic mentality are indeed ideological, but the combination and functions of the specific amalgamation in the social psychology of individuals is not identical to ideology. In the broadly Marxist sense of the word, ideology is the intellectual reflection of the economic and technological base and relations of production and serves as a kind of system of justifications for that base (Bottomore 1983, 247-250).

There are psychological aspects to ideology for Louis Althusser. According to him, ideology is the means by which capitalism reproduces itself. In this sense, the capitalistic

\footnotetext{
${ }^{44}$ According to Williams' most comprehensive definition of hegemony: "It is a whole body of practices and expectations, over the whole of living; our senses and assignments of energy, our shaping perceptions of ourselves and our world. It is a lived system of meanings and values-constitutive and constituting-which as they are experienced as practices appear as reciprocally confirming. It thus constitutes a sense of reality for most people in the society, a sense of absolute because experienced reality beyond which it is very difficult for most members of the society to move, in most areas of their lives" $(1978,110)$. This definition of hegemony is closest to what I have in mind with the capitalistic mentality, though Williams' conception still does not emphasize the intersection of the material and social and the individual enough in my view-a lack the concept of the capitalistic mentality rectifies.
} 
mentality is within the bounds of ideology. Interpellation is the mechanism that people become individual subjects of the mode of production they are born into (Althusser 1994). What is interpellation but primarily a kind of psychological conditioning? Althusser never takes that next step to specify the psychological character of this process. Althusser's use of the terms ideology and interpellation are as expansive as they are vague and are thus not nearly as helpful as they could be. Again though, the capitalistic mentality may serve more as a supplement to this theory of ideology than an outright corrective.

Building on Althusser and Jacques Lacan, for Žižek (1989; 2005), ideology is what structures our existence. Žižek uses Lacanian psychoanalysis to interpret ideology, but ideology here is not merely the psycho-behavioral orientation of capitalist subjects. It is broader and more amorphous in these uses, and what I hope to accomplish with the concept of the capitalistic mentality is to more specifically and precisely cover the ground typically done by the concept of ideology while articulating what I believe to be a more accurate narrative of the primary mechanism by which the base influences the superstructure and the superstructure influences the base (i.e., how capitalism reproduces itself by conditioning its subject to actively reproduce it without knowing it).

The capitalistic mentality serves as a mechanism for the reproduction of capitalist norms and practice, or what we might call capitalist ideology. My concept can answer the question that Althusser might have asked: what is being interpellated, specifically? What is the specific content of the interpellation? Ideology does not reproduce itself, or if it does I believe the existing literature does not do justice to this process. Ideology must be enacted either unconsciously, subconsciously, or consciously, or some combination of the three. In this way the capitalistic mentality can be viewed as both the source and product of ideology 
without being reduced to ideology. A mentality is a psychological orientation towards the world, and the capitalistic mentality is an orientation towards the world and oneself that is the result of capitalism and serves to reproduce capitalism. ${ }^{45}$

Though neither Fromm nor Adorno use the term mentality in any theoretically specified way in their major work, I believe Fromm's work implicitly includes the concept though is incomplete. ${ }^{46}$ The use of mentality specifically in the context of the psycho-social determinants and consequences of capitalism has some textual grounding in Adorno's writing (though Adorno's use is less technically precise than Fromm's concept of social character or mass psychology).

In Adorno's Stars Down to Earth (2001), which collects a portion of his less jargonladen social critique, highlighted by his essay on astrology in the United States. We see here Adorno's most consistent use of the term mentality. ${ }^{47}$ It is worth quoting at length to understand a bit more precisely how he understands what one is studying when one is studying a mentality. He writes:

...Our study...represents an attempt to understand what astrological publications mean in terms of reader reactions, on an overt level as well as on a deeper one. While this analysis is guided by psychoanalytic concepts, it should be pointed out from the very beginning that our approach as far as it largely involves social attitudes and actions must largely consider conscious or

\footnotetext{
45 A text that was very helpful in clarifying the distinctions between mentality and these related concepts was Jan Rehmann's (2013) Theories of Ideology: The Powers of Alienation and Subjection.

46 The concept is used in some of Adorno's lesser-known work, as well as the more well-known The Authoritarian Personality (1950) quoted at the outset, though the use it still entirely undefined and regardless, this text should not be read as the singular work of Adorno as it was the product of many different scholars including Adorno.

47 The use of the term in The Authoritarian Personality, at least in the most widely cited translation, is used as a substitute term for "personality" or "character" (e.g., fascist mentality as opposed to fascist personality or fascist character, the latter two being the more common phrasings). There seems to be no discernable substantive difference in the uses of these terms. What I provide here in this chapter is consistent with Adorno's use of the term but goes beyond those uses by providing a bit more conceptual coherence to the term.
} 
semiconscious phases. It would be inappropriate to think exclusively in terms of the unconscious where the stimuli themselves are consciously calculated and institutionalized to such an extent that their power of directly reaching the unconscious should not be regarded as absolute and where overt issues of selfinterest continuously enter the picture. Frequently, surface aims are fused with vicarious gratifications of the unconscious. In fact, the concept of the unconscious cannot be posited dogmatically in any study concerning the border area of psychological determinants and social attitudes. In the whole field of mass communications, the "hidden meaning" is not truly unconscious at all, but represents a layer which is neither quite admitted nor quite repressed - the sphere of innuendo, the winking of an eye and "you know what I mean." Frequently one encounters a kind of "mimicking" of the unconscious in the maintenance of certain taboos which, however, are not fully endorsed. No light has so far been thrown on this somewhat obscure psychological zone, and our study should among other things contribute to its understanding. It goes without saying that the ultimate basis of this zone has to be sought in the truly unconscious, but it might be a dangerous fallacy to regard the psychological twilight of numerous mass reactions as straightforward manifestations of the instincts. (2001, 53-54)

The next three paragraphs go on to use the term mentality three times in a general way to refer to this psycho-social dimension being studied. Later in the same collection Adorno writes, referring to an astrological column in the newspaper: "the column profits from the same mentality which draws people to gambling, horse betting and similar devices for making easy money. Propensity for irrational material gain seems to be contingent upon the shrinking chances of making big money as a pioneer or on a rational basis of calculation" (117). To reiterate, my use of the term mentality refers to a loosely structured, self-reinforcing way of thinking that typically results in certain behaviors. It is not just what is thought, but how it is thought. Specifically, the capitalistic mentality refers to the particular way of thinking and the behaviors that are typically present and normalized under capitalist systems. 
My argument, though it focuses on and calls for a re-emphasis on the psychosociality of capitalism, it is not a kind of reductionist psychologism. I am not suggesting here that capitalism is defined entirely by its psychological dimensions, or even that that capitalistic mentality is a purely psychological concept. I want to offer a new concept derived from two thinkers whose bodies of work are underappreciated with regard to how we define and understand capitalism. Fromm is rightly viewed as criticizing the psychological neuroses and pathologies that are a result of capitalism and mass consumer society. Much of Adorno's work has been interpreted as speaking to consequences of industrial and early consumer capitalism on art and society as well as philosophy's inability to cope with these historical developments. What this chapter will argue is that since Marx first began to conceptualize the nature of capitalism (what he referred to as the capitalist mode of production), through Weber and Lukács to the Frankfurt School (with most secondary literature typically only focusing on the Freudo-Marxism of Herbert Marcuse), there has always been an understanding that there is a psycho-social aspect to capitalism that has its roots in its relations of production but necessarily exceeds those roots and the realm of economics entirely.

\section{Capitalism in General: Exorcising Market-based Understandings}

Capitalism today is most often associated with (free) markets. According to this commonly held view, the degree to which markets are present and free is the degree to which we have capitalism (Harvey 2007). This is not just an argument made by Nobel Prize-winning economists such as Milton Freidman (1982), but also by Marxist historians such as Ellen Meiksins-Wood (2002; 2014) or Leo Panitch and Sam Gindin (2012). While 
these thinkers are right to point out that where we see markets we often see capitalism, and that capital's internal logic calls for the expansion of markets, they are also misleading because markets historically preceded capitalism and there is a whole body of literature focused on kinds of market socialism, which suggests that markets could outlive capitalism and thus cannot be reasonably considered a defining characteristic of a singular mode of production or economic system. This implication requires that we look more deeply at what it is that is peculiar about capitalism that makes it capitalism. ${ }^{48}$

The market that is most often present in all forms of capitalism is a market between labor and business, that is to say laborers sell themselves on a market (for a wage) to the owners of the means of production. Though this wage market is something that is historically exclusive to capitalism, markets in and of themselves certainly preceded capitalism and even feudalism. Since the advent of barter economies there have been markets, however simplistic these initial markets were. Conversely, the market was not the primary organizing principle for the exploitation of the Soviet Union, Cuba, "communist" China, or North Korea-all versions of what Fromm and others refer to as "state capitalism" (capitalism, because there remained a functionally private ownership of the means of production that determined the relations of production and the expropriation of surplus-value that was remunerated in the form of [minimal] transfer payments, including coupons and ration books). Though the contemporary incarnation of the capitalistic mentality is certainly shaped by the pervasiveness of markets, the capitalistic mentality is rooted more deeply in the core, defining characteristics of capitalism first specified by

\footnotetext{
${ }^{48}$ See the work of David Schweickart (2002) and John Roemer (1996) for examples of market socialist arguments.
} 
Marx and elaborated on by Max Weber, both of which form the foundation of Adorno's and Fromm's work.

Marx tells us that it is the expropriation of surplus-value by the owner of the means of production partially remunerated in the form of a wage paid to a laborer. Sociologically, Weber moves beyond this and suggests everywhere we see this relationship, we also see the pervasiveness of the profit-motive or the motive to accumulate take precedence above other social desires. Typically, historically, we have seen these two traits occur within market and non-market (or more restricted market) contexts. For Marx, there are certain characteristics of capitalism, such as private property and markets that are certainly important, yet precede capitalism. By looking at the word "capitalism" we can see that it is a system that is dominated by capital. Capital is a relation of power represented in substance (e.g., a factory) or physical representation (e.g., money or stock) which embodies accumulated labor and potential exchange-value (Grundrisse, 243-244). Everything thus must become exchangeable in order to be useful, or so the mythology goes.

Beyond use-value (that is the actual usefulness of a thing to achieve a desired end), a thing must have exchange value under capitalism to be deemed important. In fact, as we will get into more deeply in the following sections, use-value becomes identical to exchange value under capitalism (Capital Vol. 1, 303). In other words, people tend to look at the salability of a thing as its use (they think: "This item is useful to me if I can sell it, preferably for more than I spent on it."). This process of the increased dominance of exchange value (and the identification of use-value as exchange value) is what Marx called "commodification." What is the result of this process? What is a commodity, a word we often use without questioning its meaning? "A commodity is, in the first place, an object 
outside of us, a thing that by its properties satisfies human wants of some sort or another" (Capital Vol. 1, 303).

Though the fullest exposition of commodity fetishism comes from Lukács (1971), who will be discussed later in this chapter, Marx was the first thinker to discuss the process by which the commodity form is fetishized. It is worth quoting Marx at length here: "So far as it [a commodity] is a value in use, there is nothing mysterious about it whether we consider it from the point of view of satisfying wants, or from the point that those properties are the product of human labor" (Capital Vol. 1, 319). "A commodity is therefore a mysterious thing, simply because in it the social character of men's labour appears to them as an objective character stamped upon the product of the labour..." (320). The commodity is therefore a mediation between the laborer and their labor. We do not see the labor embodied in the value of that commodity but rather only the commodity's physical forman objective thing.

Since producers do not come into social contact with each other until they exchange their products, the specific social character of each producer's labour does not show itself except in the act of exchange [where exchange value manifests]. In other words, the labour of the individual asserts itself as a part of the labour of society only by means of the relations which the act of exchange establishes directly between the products, and indirectly, through them, between producers....[T] herefore, the relations connecting the labour of one individual with that of the rest appear, not as direct social relations between individuals at work, but as what they really are, material relations between persons and social relations between things. It is only by being exchanged that the products of labour acquire, as values, one uniform social status...." (Capital Vol. 1, 321)

The labor process is mystified by the commodity form and the exchange value comes to signify the false identity of use and exchange value. Whether or not this exchange takes place in a free market is foundationally (though not historically or comprehensively) 
irrelevant. Commodification and the exchange of the commodified thing, can take place in a market or not, though historically markets have played an important role in the seemingly unnoticed commodification of previously non-economic spheres of life. ${ }^{49}$

In what way then does this commodification have its roots uniquely in the capitalist mode of production? Beyond the commodification of labor and the increasing commodification of more and more aspects of human existence (including humans themselves of course), the other unique aspect of capitalism is surplus-value expropriated from laborers in the form of a wage (i.e., wage-labor). Surplus-value recall is the excess produced by the laborer beyond the value produced in the labor time that becomes his/her eventual wage. If a worker works for eight hours, he/she will likely produce the value of their wage in the first couple hours. They receive this value as a wage, but they must work beyond those two to three hours in order to receive any wage at all (this value is spread out over an entire shift through the hourly-wage). The value that comes from the additional time worked goes directly to the owner. It is not the same as profit in the broader sense, though it is profit in a more narrow sense that it is the cost of labor minus the wage paid. However, profit typically means the overall revenue of a company minus its overall costs, including the cost of labor, but also capital investments in factories, distribution and the basic materials needed to produce the commodities. "Half the working day costs capital nothing; it thus obtains a value for which it has given no equivalent" (Grundrisse, 248). This is the foundational, essential element of capitalism. There are many other components that work together to allow for surplus-value and wage labor to occur, but without this core

\footnotetext{
${ }^{49}$ For similar though non-Marxist arguments see Michael Walzer's Spheres of Justice (1983), Michael J. Sandel's What Money Can't Buy: The Moral Limits of Markets (2012), and Axel Honneth's recent work Freedom's Right (2014).
} 
quality capitalism could not function as such and would thus cease to be capitalism (249). Following from that, we will have not gone beyond capitalism until this relation of production has ceased.

The result of the expropriation of surplus-value through a wage is both the commodification of labor and the alienation of the laborer. ${ }^{50}$ The laborer is only important to the business-owner so long as they produce efficiently saleable products (and more so in the late twentieth and twenty-first century, saleable services). However, the laborers' labors are not her own any longer, nor are the products of those labors, nor are the conditions under which she labors. Labor is estranged. Labor is alienated every step of the way, and for Marx this alienation is exploitative in and of itself and thus unacceptable. ${ }^{51}$ What is even more problematic, and especially relevant to the capitalistic mentality, is the fact that alienated labor is both the product and result of capitalism. It is self-perpetuating. The more the laborer labors (in order to earn his wage or perhaps an even higher one eventually), the more saleable capital is produced for the owner, which will allow the owner to make more money and thus expand his/her business (Grundrisse, 229-231). Expansion requires more labor, and thus the owner will hire more workers who will become alienated from their labor. There is a necessity to this for the laborer; without other options for securing a living for themselves and their family, people need to sell their labor if they are unfortunate enough to not be born into a situation where there are ample opportunities to join the exploiters and operate their own business (Wage Labour and

\footnotetext{
${ }^{50}$ The concept of alienation is discussed more in Marxian terms in the Introduction, and will be expanded on in this chapter when we get to Fromm's use of the concept.

${ }^{51}$ It is the clarity with which we read in Marx that alienation and exploitation are normatively unacceptable where we detect a clear ethical/moral dimension to his work. If Marx were supposed to be (or even best) read as a pure scientific analyst of capitalism as someone like Althusser supposedly argues, how else would we be able to say that alienation and exploitation are not good things?
} 
Capital, 204-205). Even still it seems we are confronted by two fairly terrible options, the latter of which is only accessible to a small minority: be exploited or exploit. ${ }^{52}$

Alienation and commodity fetishism are both deeply psychological, both rooted in surplus-value and wage labor (Grundrisse, 260-261). They are social psychological and material products of capitalist relations of production which produce capitalistic subjects engendering a capitalistic mentality.

Early twentieth century sociologist Max Weber was highly influential on Lukács and the Frankfurt School. I am less concerned here with Weber's actual influence on the other thinkers addressed in this chapter as that work has been exhausted in other texts more exclusively dedicated to that theme. ${ }^{53}$ Neither Lukács, Adorno nor Fromm generally accepted Weber's most well-known empirical contribution to sociology, namely his argument that Protestantism contributed to the growth, spread, and "success" of capitalism (by encouraging a decidedly "capitalist" spirit. ${ }^{54}$ This is Weber's argument in The Protestant Ethic and the Spirit of Capitalism ([1901] 2002). What I want to briefly explicate here are the broader implications of Weber's argument regarding the connection between an economic system (capitalism) and the way people think and act. Then I will explain how Weber's rationalization thesis (which was taken up by Lukács and the Frankfurt School) does feature specifically in my development of the concept of the capitalistic mentality. For those who question the Marxian bias of the argument this chapter

\footnotetext{
52 The labels "exploited" and "exploiters" are often substituted for extended euphemisms like "selfmotivated individual working their way up from the bottom" or simply "a really hard worker" (for the exploited) or "entrepreneurs" or "job-creators" (for the exploiters). The discourses of capitalism and its agents mystify the true nature of these social relations, and at its most successful turns something like exploitation into a normatively valued, prestigious vocation (Fromm 1976).

${ }^{53}$ See Douglas Kellner (1985; 1980), Andrew Feenberg (1981; 2014), and Martin Jay (1973).

${ }^{54}$ Ibid.
} 
presents, the contribution of Weber should indicate that one need not be an outright Marxist to accept the argument that there is indeed an important psycho-social aspect to capitalism.

Recall in the introductory chapter Weber's ideal-typology of capitalism is that it is a system defined by the presence of a mental drive towards profit and accumulation above all other things. In a society rooted in the encouragement of laboriousness within the emergent Protestant tradition: “...value was placed on ceaseless, constant, systematic labor...[it] was inevitably the most powerful lever imaginable to bring about the spread of that philosophy of life which we have termed here the 'spirit' of capitalism" (Weber 2002, 116). Generally speaking, everything becomes subordinated to the profit-motive. "Capitalism is...identical to the striving for profit, in the course of continuous, rational capitalist enterprise, for more and more profits...It must be (359).

Though Weber does not characterize them specifically as such, the profit-motive and the drive to accumulate for its own sake are both social psychological conceptualizations. What is a motive or a drive if not psychological? Could capitalism survive or even exist if these drives did not? Weber's work, however accurate or inaccurate it may or may not be regarding capitalism's actual connection to the development and spread of Protestant beliefs, still provides ample evidence that the spread and instantiation of capitalism throughout Europe coincided with the development of certain ways of thinking and behaving that were not previously prevalent or normalized. ${ }^{55}$

\footnotetext{
55 Though the point of this chapter and project is not an historical sociology of the development of capitalism, Marx provides that historical sociology detailing the ways in which the emergent bourgeoisie and Enlightenment thinkers, still within the late confines of feudalism developed and articulated norms which conformed to their more mercantile, less agricultural, landed way of earning their living. Habermas's Structural Transformation of the Public Sphere (1989) is instructive on this development as well.
} 
Related to this Protestant ethic thesis is a more precisely relevant aspect of Weber's work which speaks to the rationalizing social and political tendencies of modernity more broadly. This argument pervades Frankfurt School thinking, though certainly with critical deviations. For Adorno and Fromm specifically, they are concerned with the irrational (and for Fromm, literally insane) results of this rationalization of society. Weber argued that modernity is characterized by an increased purposive-technical rationality (what Horkheimer and Adorno would dub instrumental reason). As European societies moved further from their medieval feudal past, capitalist modernity was becoming more secularized and more focused on solving the problems of collective living through technical-analytical reasoning based on increasingly positivistic premises. So taken together, capitalism has its roots in the protestant ethic but develops beyond these religious associations into a secular bureaucratic instantiation of instrumentalized progress (Kellner $1983 ; 1989)$.

Society thus loses its ability to critically evaluate the ends or goals toward which it aims. People become strictly focused on the best way to achieve the uncritically accepted ends provided by society - in the case of capitalism that means accumulation for its own sake and the profit-motive more specifically. According to Weber, capitalism and rationalization go hand in hand, at least in the case of successful capitalist enterprise. If a capitalist enterprise is not rational and technically efficient, displaying the most practiced kind of instrumental rationality, it "would be doomed" (Weber 2002, 359-363). Adorno and Fromm, through Lukács, expose how this rationalization, this means-focused mentality, leads to a kind of irrationality or social insanity. What is important to note in regards to the capitalistic mentality is this psycho-social aspect of capitalism, this 
intersection of profit, accumulation, and instrumental rationality. These are psychological concepts with behavioral manifestations. Though Weber is very comfortable referring to this instrumentalization of human cognitive power as a kind of rationality, Adorno and Fromm individually would come to the conclusion that capitalist rationality was deeply irrational in that it conflicted with the possibility of critical reasoning people needed to avoid the perils of dehumanizing mass movements like fascism and Nazism.

With the combination of Marx and Weber, we now have a working definition of capitalism. Capitalism is an expanding socio-economic system defined by the generalized presence of a drive for accumulation for its own sake rooted in the commodification of labor, itself based on the predominance of a production relationship of surplus-value expropriated from the actual producers in the form of a wage. While this definition is quite different than the one offered by the cosmopolitan thinkers discussed in the previous chapter, where they even offer one, it is not to suggest that any discussion of markets is entirely irrelevant. Quite the opposite is true. The broader point in this chapter is less that it is problematic (though still problematic) to focus on markets and not surplus-value, profit, wage labor, private property, or the other dimensions central to capitalism, but rather that by focusing on the purely non-humanistic, non-mental aspects of the economic system, a vitally important element of how that system functions and its effects end up largely overlooked.

\section{Adorno and the Amnesia of Commodification}

Before delving into Adorno's work, we must explore one more predecessor who played a major role in the development of his thought, Georg Lukács. Lukács (1971) 
himself also offered a convincing psycho-social understanding of capitalism, and class in particular, through his conceptualizations and examinations of class (and false) consciousness and reification. Lukács's primary endeavor, at least in his discussions of these concepts, was to explain why revolution hadn't occurred in the places where Marx suggested it would, namely Western Europe and the United States. He argued that the ideological dimensions of capitalist relations of production mystified people's (the proletariat's) understandings of their own interests, especially how their interests conformed with other people's interests, at least within the working class (Lukács 1971; McLellan 1979, 158-159).

Interest in this context was not a subjective fact, it was an objective truth based on one's relations to the means of production. The subjective perception of one's interests is where the mystification comes into play. The proletariat's subjective perception of their own interests (continuing going to work, voting instead of revolting, fighting wars on behalf of the bourgeoisie, etc.) diverged from their objective interests (collective revolutionary action to upend the exploitative regime of legalized wage slavery). Lukács referred to this divergence as false consciousness. On the other hand, when a class's perception of its interests and its actual objective interests coincide, they have achieved true or class consciousness. Class consciousness is the prerequisite for revolution (Lukács 1971; McLellan 1979, 160-161). The fact that there is almost no class consciousness speaks directly to the historical lack of revolution in the Western world. False consciousness can be considered a tangential component of the capitalistic mentality. Wherever we see capitalism we also see the psycho-social delusion perpetuated by the ruling elites, that revolution is unpatriotic or irrational, that workers have too much to lose from revolting, 
that workers benefit more than they would from any other system, that there are bad guys in other countries who want to come steal their jobs and thus the workers in one country stand opposed to those in another (McLellan 1979, 158-159).

Reification is the psycho-social mechanism through which the formation of class consciousness is prevented or at least undermined, while false consciousness becomes more and more entrenched. Reification is present when people are unaware of their factual relation to the systems of production and exchange. "Reification means, literally, treating human relations as relations between things" (Lukács 1971; Feenberg 2014, 62). This concept finds its root in Marx's notion of commodity fetishism discussed in brief earlier. Reification happens when people no longer feel or comprehend their agency in a world that compels them to become spectators in their own lives, and this historically happened primarily through the pervasiveness of the commodity form but modern economic and political bureaucratization as well (McLellan 1979, 161-162). The dominance of the commodity form is premised on reification, as explained above. The identity of all value with exchange value and the hidden character of the exchange process are exemplary of reification. Commodity fetishism is thus maintained by reification. Commodification both (re)produces reification and is (re)produced by reification. Reification becomes the total reality of capitalist society. It is the character of its consciousness for both the bourgeoisie and the proletariat (Lukács 1971, 149-150).

It is based on Lukács's analysis of the relationship between the commodity form and reification where we find Adorno drawing his psycho-social depiction of capitalism. Though much of Adorno's theory of negative dialectics and critique of identitarian thinking is rehearsed in the Introduction, it is extremely important to the overall thesis of this project 
and warrants repeating some of. As the basic methodology or approach of this project is negative-dialectical it looks for the conceptual contradictions immanent to an argument but also to its external contradictions in practice. Negative dialectics serves a deeper role here as well. The kind of thinking that is characteristic of the capitalist mode of production is the kind of thinking Adorno excoriates through negative dialectics. That mode of thought is identitarian thinking (Adorno 1973; 2008). Identitarian thinking itself coincides with the mentality of the subjects of capitalism - their capitalistic mentality.

Identitarian thinking is a way of thought that takes concepts to be complete and mirror the reality they supposedly refer to. Coincidental to identitarian thinking is reification. Similar to Lukács's use of the term, Adorno argues more simply that reification is the forgetting that one is erroneously participating in identitarian thinking. Every time we use language we are identifying our words with a reality, which is problematic enough, even if we are conscious and self-reflective that we are doing this. Reification is the wall that goes up; it is the social brain damage that erases the falsity of identitarian thinking. Reification normalizes the false identity between word and concept. "Your words $d o$ mirror reality accurately" it whispers to us, and then we forget even that whisper. Now it is truth. Identitarian thinking is unconsciously accepted and consciously practiced, without question. Reification merely magnifies the problems of identitarian thinking by disallowing self-conscious critical reflection on the implications of our urge to identify, and our inability to successfully mirror reality with our words (Adorno 1973; 2008).

Identitarian thought preceded capitalism; however, identitarian thinking is required for capitalism. Capitalism could not function without this psychological dimension. Identitarian thinking is the basis for the exchange of commodities and the wage labor 
relationship. In order for a laborer to accept her wage, she must believe or accept the social norm that her labor is equivalent to her wage. In order for me to accept paying $\$ 2$ for a soda, I must to some degree accept the identification of the value of the currency and the value of the product. If this were not the case, how could this exchange system ever be legitimized? Everything would be a swindle. Every exchange would be viewed as a kind of cheating or theft (i.e., usually what it actually is). Even between owners this identitarian thinking must be present. In order for an owner to sell his/her company for a certain amount of money, each must view the company as roughly identical to the value of the value of the currency expended (even if the value is being viewed as a potential or speculation of future growth). More fundamentally though, in order for commodities to be exchanged we must identify them with their supposed value.

According to Marx, one of the fundamental differences between feudalism and capitalism is that under feudalism everyone knew the serfs were getting taken advantage of (to put it rather mildly) by the lords. Under capitalism, the laborer graciously accepts their wage and views the owner with perverse affection. ${ }^{56}$ Because this identitarian thinking is normalized and reified, the wage laborer has yet to realize, as the bondsman (or slave) does in Hegel's metaphor of the speculative dialectic, that the lord (or master) is paradoxically dependent on the labor of the bondsman, and the bondsman is allowed to express his productive powers while the lord's humanity shrivels up in a relationship of

\footnotetext{
${ }^{56}$ According to Gramsci (1971), this is how hegemony works. We accept the dominance of capitalism not because if we don't we will be exposed to violent repression, but rather because we come to believe in it. We come to accept that capitalism can indeed benefit us better than other systems could. In this sense, the capitalistic mentality can be viewed in collaboration with hegemony. The capitalistic mentality is the mechanism for the reproduction of hegemony while also contributing to the content of that hegemony.
} 
dependence (to exaggerate the metaphor a bit). ${ }^{57}$ Under capitalism, the laborer identifies the business owner with his own capacity to survive (and in the Western, post-industrial world, to buy things he needs to possess to be viewed by others as a real person). The laborer is thus thankful to his oppressor for his oppression. The laborer under capitalism experiences the relations of production as something akin to a socially constructed Stockholm syndrome.

In Dialectic of Enlightenment (2007), the same collection where the contradictory nature of enlightenment is exposed, Adorno's most well-known contribution to twentieth century social thought, his theorization of what he called the culture industry ${ }^{58}$ is explained. Prior to Adorno's elaboration of the culture industry, he wrote the "Fetish Character of Music and the Regression of Listening" ([1938] 2002). Here Adorno prefigures that argument using language we will find repeated there and in Negative Dialectics, written much later. "...[E]verything is so completely identical that preference in fact depends merely on biographical details or on the situation in which things are heard. The categories of autonomously oriented/intended art have no applicability to the contemporary reception of music; not even for that of serious music, domesticated under the barbarous name of classical so as to enable one to turn away from it again in comfort" (289). Adorno's point is that the mass production of music has led to it becoming devoid of originality and creativity. It is made for a mass audience and thus in order to be palatable to the maximal

\footnotetext{
${ }^{57}$ Adorno tells us in Minima Moralia the only true aspects of psychoanalysis are the exaggerations (2005, 49).

${ }^{58}$ Earlier in Adorno's work the concept of the culture industry was represented by the phrase mass culture, a phrasing he abandoned because he believed it wrongly implied that this development came from the masses, as opposed to being a product of bourgeois capitalist ideology.
} 
amount of potential customers, is composed with little sophistication. Sophistication is only necessary insofar as it serves the ends of profit.

Art has become a mass commodity. However, this is not the pure form that Adorno wants to label art. He would much rather say that the identity of what we now call art is no longer identical to art. There was always that negative dialectical space inherent in the concept, but under conditions of consumer capitalism that contradictory space has become an extreme separation and near-absolute opposition. Mass culture is a false totality; it is a fraudulent misrepresentation of what true art can be (Adorno 1984; Horkheimer and Adorno 2007).

The concept of musical fetishism cannot be psychologically derived. That "values" are consumed and draw feelings to themselves, without their specific qualities being reached by the consciousness of the consumer, is a later expression of their commodity character. For all contemporary musical life is dominated by the commodity form: the last pre-capitalist residues have been eliminated. Music, with all the attributes of the ethereal and sublime which are generously accorded it, serves in America today as an advertisement for commodities which one must acquire in order to be able to hear music. $(2002,289)$

Adorno tells us that this phenomenon cannot be psychologically derived, however this is very different from saying it doesn't have psychological effects and that the tendencies it normalizes cannot be psychologically reproduced. What Adorno is arguing is that this phenomenon of the culture industry is not rooted in unconscious drives, as an orthodox Freudian would be compelled to argued, but rather it is a psychological manifestation of particular relations of production. It is the effect (and affect) of the fetish character and the culture industry that is most important to us here. Broadly, if art had any critical potential, mass culture, and particularly the commodification of art by the culture industry, has eroded it. It is devoid of any controversy, unless is it a controlled, contrived, 
profitable controversy. What is cultivated is not thinking but enjoyment masquerading as everything and anything else, to such a degree that mass art can eventually abandon the pretext of being anything else other than enjoyment. We now simply understand the purpose or art and culture to be enjoyment. The reification of art through its identification with amusement contributes to the reproduction of the capitalistic mentality. This becomes a psychological condition. If art is unpleasant the people ignore it or reject it. That is to say, in more general terms, if a piece of art fails to comply with the dictates of instrumental reason, if it fails to have a clear purpose for its existence, it tends to be rejected. The enjoyment we come to demand to replace our critical thinking is a shallow enjoyment. The culture industry cannot live up to its own promise to provide truly cathartic pleasure. Such a pleasure would be uncontrollable and thus unprofitable (Horkheimer and Adorno 2007, 111).

The culture industry is anything but rigid though. It is actually highly adaptable, like capitalism itself. It can identify anything with anything. Adorno's critiques focused heavily on jazz, but we can see how the culture industry functions today in different genres. For example, we can see the anaesthetizing, normalized, sing-a-long drivel produced under the heading "Pop." We can also see how the lack of enjoyment in music can become its own enjoyment. We see this with death metal and screamo. These genres allow people to carve out a perception of uniqueness by their ability to enjoy the supposedly unenjoyable. This is no exception to the psycho-sociality of the culture industry. This is reification as well. The fans of these genres fail to see how this kind of music becomes commercialized and mass-produced as well. The trends within actual pop music and other supposedly fringe musical genres are not only similar but actually part of the same trend, the culture industry. 
The failure to appreciate (i.e., to see and acknowledge) the commodification of everyday life, or art, of what we watch on television or YouTube is an example of the reification that reproduces capitalism. In order to enjoy mass art, and enjoyment being the ideologically given demand of modernity and postmodernity, we must never think too deeply about. "Don't overthink it; just enjoy it," we are told, and if you do overthink it and are left depressed or unsatisfied, well, that is your own fault. "Do you want to be happy? Don't be so critical" we are taught. The shallow enjoyment we experience as spectators in our own society, in our own lives is non-identical to true enjoyment, to true happiness though. ${ }^{59}$ It is a false totality of amusement that serves as a distraction from our alienation, exploitation, and commodification (Horkheimer and Adorno 2007, 104-109). We are distracted — and distanced — from a fuller realization of ourselves, of our species-being, by the identification of distraction with happiness. This is all part of a mentality whereby ideology and reification become reality for our generation and those that follow under the capitalist mode of production. ${ }^{60}$ "Entertainment is the prolongation of work under late capitalism. It is sought by those who want to escape the mechanized labor process so that they can cope with it again" (109).

Adorno extends Lukács's exposition and elaboration of Marx's concept of commodity fetishism and the commodity form that becomes predominant under modern capitalism. Combined with Weber's rationalization thesis, Adorno's primary concern

\footnotetext{
${ }^{59}$ Such an idea as true happiness is much more imaginable for Fromm than it is for Adorno.

${ }^{60}$ Though Adorno surely had a tendency to come off as a cultural conservative, favoring bourgeois perceptions of high art. Under mass society high art becomes subjected to the same forces as "low art." Though there is more radical potential in reinvigorating the progressive and creative tendencies of classically high art, it is only through reinvigorating and rearticulating that potential in a non-reified manner, that the radical potential of art can be realized. This is what Adorno was attempting to articulate in his unfinished Aesthetic Theory.
} 
becomes showing how the identitarian impulse of modernity and capitalist bureaucratization became a contingent one-way ticket to fascism, the Nazi concentration camps, and the Holocaust. For Adorno there are shocking and disturbing similarities between fascism and American mass culture (Adorno 2001, 223-224). They are both rooted in identitarian thought and the reification that is embedded in the capitalist mode of production.

Nazism, and fascism more broadly have a fetish for identifying purity and purging all supposed impurities. According to Adorno this is the culmination of the identitarian thinking that is demanded by the extremity of self and social deception (reification) required by capitalist exchange relations. Fascism compelled people to exercise a faculty that capitalist modernity has already honed in them: the ability to identify non-identicals and purge all residuals. Human Jews are now equal to non-human animals, and non-human animals are instrumentalized to serve our needs and can be disposed of at our pleasure. Radicals no longer possess rights to express themselves. Homosexuals and ethnic minorities are no longer free to exercise their identities in public or private- they are denied the right to exist completely (Horkheimer and Adorno 2007, 120-123). Humanity becomes non-identical with people, and the supposedly Aryan Germanic characteristics become identical with humanity. This mentality combined with the ever-expanding horrific efficiency of bureaucratization and hyper-organization of human life under modernity results in Auschwitz (both historically and conceptually), according to Adorno. So long as these psycho-social tendencies remain prevalent within our civilization, the possibility for another Auschwitz, for another Holocaust, remains. "[Our] lack of resistance certifies [us] as reliable customers (124). "[P] ersonality means hardly more than dazzling white teeth 
and freedom from body odor and emotions" (136). This is the fascistic character latent in the capitalistic mentality and the culture industry which reproduces and normalizes it.

\section{Fromm and the Insanity of Capitalism}

Though the major studies of the Frankfurt School from Martin Jay’s well-known Dialectical Imagination (1973) and Rolf Wiggershaus's The Frankfurt School (1994) to David Held's Introduction to Critical Theory (1987) present Adorno and Fromm as being inconsistent and opposed to one another, I believe that if we are to put their divergent interpretations of Freud aside (the principal disagreement between the two), both theorists convey a psychologically-informed understanding of capitalism and capitalist society. Though Fromm tended to go about his analyses of capitalist society from a more conventionally psychoanalytic perspective, as opposed to Adorno's more culturalsociological and philosophical approach, the discussion of Fromm that follows will show that it is their similarities that are more productive for us to examine. By understanding their psychoanalytic convergences, we can come away with a sharper, more useful CriticalTheoretical perception of capitalism than we can from highlighting their divergences and historical disagreements that eventually led to Fromm leaving the coterie at the Institute for Social Research after their emigration to the United States in the 40s. Beyond their compatibilities and similarities, it is only when we reconstruct a unified theory out of the works of these thinkers that we, in the twenty-first century, can gain a more comprehensive appreciation for the psycho-sociality of capitalism manifested in the capitalistic mentality. Both thinkers were greatly influenced by the earlier attempt by Wilhelm Reich to merge 
Freudianism and Marxism. However, Fromm drew more directly from Reich's concept of character structure and mass psychology (specifically regarding fascism). ${ }^{61}$

Fromm's first major work Escape from Freedom ([1941] 1994) introduces us to his concept of social character and provides an interesting social psychological history and sociology of freedom, a kind of dialectical reversal of Hobbes' argument. Fromm tells us that modernity and liberal capitalism freed us from the bounds of a rigidly hierarchical feudal system where our life goals and opportunities were completely beyond the control of an individual person. To such a degree, he argues, the concept of the individual as we know it had not yet emerged. Then came the bourgeois revolution and all that changed. People have the freedom to choose for themselves, but this new capitalist mode of production could not provide the social ties and connectivity that was valued under feudalism. People became isolated and alone, freer yes, but unable to fully develop their creative potentials or to fully enjoy their supposed freedom. Modern capitalism went too far in terms of individualism. It ended up pitting man against man, which, contrary to Hobbes' argument and many others since, is against the best nature of humanity. The isolated capitalistic individual is the subject of Fromm's life-work and my own project here.

The loss of what Fromm calls "primary ties" (our connections to our communities, to our work, to one another) under the capitalist mode of production is part of his broader critique of alienation (Fromm 1994). This loss of primary ties is loosely equivalent to

\footnotetext{
${ }^{61}$ See Reich's Character Analysis ([1933] 1990) and The Mass Psychology of Fascism ([1946] 1970). Also, for an interesting intellectual history of Freudo-Marxism see Russell Jacoby's The Repression of Psychoanalysis: Otto Fenichel and the Political Freudians (1983). For a more original interpretation of the various attempts to combine psychoanalysis and Marxism extending to Deleuze and Guatarri's work see the late E.V. Wolfenstein's Psychoanalytic-Marxism: Groundwork (1993), a superb and ambitious text which was intellectually influential and practically useful as I was constructing the arguments in this chapter.
} 
humanity's alienation from itself, others, and nature. Alienation according to Fromm's interpretation of Marx is the phenomenon whereby humans are unable to relate themselves authentically and creatively with themselves, their labor, one another, nature, and though underdeveloped in both thinkers' works - with what they eventually consume (Fromm 1961, Ch. 1). “Marx's [and thus Fromm's] central criticism of capitalism is not the injustice in the distribution of wealth; it is the perversion of labor into forced, alienated, meaningless labor, hence the transformation of man into a "crippled monstrosity"' (Ch. 4.2). For Marx, humans are alienated in six ways: from the labor process, from the product of labor, from themselves (as an individual person), from their species-being (freely chosen labor), from other people/laborers, and finally from nature (Economic and Philosophic Manuscripts of 1844, 72-81).

Fromm focuses on four of these (or more accurately, merges the six into four). For Fromm capitalism alienated us from ourselves (as a creative, spontaneous individual) by compelling us to labor in monotonous ways. We are also alienated from this process of labor because we do not have any say in how it is conducted. We are alienated from one another because capitalism forces us to focus so much on ourselves and earning a living to survive and consume consumer goods we end up viewing others either instrumentally towards those ends or as impediments to those ends. Finally, we are alienated from nature. Nature, to us as capitalist subjects, is nothing but something to be exploited. We are also not a part of nature. Nature is outside. We are not animals. According to Fromm, ideally people should consciously think about the duality of our existence with regard to nature; we are both constitutive of and by nature, but we are also apart from it due to our higher 
brain function and capacity for self-awareness and self-reflection (even if we use very little of these capacities very often) (Fromm 1961, Ch. 5).

There is a passivity inherent in the process of alienation as well. Through individuals' disconnectedness from all aspects of their objective conditions, they experience themselves as an object devoid of a supposedly inherent subjectivity (Fromm 1961, Ch. 5). Very similar to Adorno's negative dialectical conception of the distance between a word and the concept that the word purports to represent, Fromm argues that there is an alienation within language, or at least our modern use of language. Fromm tells us, "one must always be aware of the danger of the spoken word, that it threatens to substitute for the living experience....[there is] a temptation to confuse life with things, experience with artifacts, feelings with surrender and submission" (Ch. 5). Under the conditions of consumer capitalism, this reification of reality leads to the desire to accumulate more money for its own sake. We lose sight of the original purpose of currency and wealth: to meet humanity's needs and true creative desires efficiently. Quantity becomes identical to quality.

As stated earlier, Fromm's central contribution to the concept of the capitalistic mentality, as the concept that most closely relates to my earlier definition of mentality, is his notion of social character. Social character is the most common, generalized character orientation in a given society at a given historical time. "Character traits underlie behavior and must be inferred from it; that they constitute forces which, though powerful, the person may be entirely unconscious of....[T]he fundamental entity in character is not the single character trait but the total organization from which a number of single character traits follow" (Fromm [1947] 1990, 57). "[C]haracter can be defined as the (relatively 
permanent) form in which human energy is canalized in the process of assimilation and socialization (59). According to Fromm, the total organization of character is a "syndrome" or character orientation (57-60). This concept is also where we find Fromm's fundamental divergence from Freudian orthodoxy. For Fromm, the structure of the character orientation of an individual is not libidinous in a sexual sense, but rather libidinous in terms of how one expresses oneself and relates to society (58). Social character is the particular organization of traits, the particular syndrome that is most prevalent in most people in a given society. It is how our psychic energies are channeled.

There are several character orientations that Fromm elucidates in several of his texts in slightly different forms, but the one we are most concerned with here is the marketing orientation, which will be extrapolated to the marketing social character of the whole society, generally speaking. The marketing character orientation is precisely what it implies: "The market concept of value, the emphasis on exchange value rather than use value, has led to a similar concept of value with regard to people and particularly oneself. This results in "the character orientation which is rooted in the experience of oneself as a commodity and of one's value as exchange value" (Fromm 1947, 68). People judge themselves and each other as lacking intrinsic, supra-market value. The ubiquity and viral nature of the commodity form degrades the potentiality of humanity in each human. Use value becomes instrumentalized as exchange value. "The modern market is no longer a meeting place but a mechanism characterized by abstract and impersonal demand" (68). Personality traits end up being sold or exchanged in the same way as commodities, in a crude identification of use value with exchange value. Previously, personality traits were not commodified. This is a characteristic trait of the capitalist mode of production (69-70). 
From his concept of character orientation, Fromm derives the broader, less individualistic social psychoanalytic idea of social character. It "is the intermediary between the socio-economic structure and the ideas and ideals prevalent in a society. It is the intermediary in both directions, from the economic basis to the ideas and from the ideas to the economic base" $(1962,87)$. Thus for Fromm the marketing social character is the social character of Western societies in the mid- to late-twentieth century, extending now to the twenty-first century in my application.

Let me be clear: Fromm associates this character orientation and social character primarily with the market, but it is because it is only principally when the market becomes entrenched in Western societies that Fromm sees the fullest entrenchment of this particular social character. As I mentioned earlier, though under capitalism exchange often does take place via markets, they need not necessarily. We see the roots of the marketing social character in commodification and commodity fetishism. It is certainly exacerbated by the historical presence of markets to be sure, but what is fundamentally problematic beyond the alienating effects of wage labor and commodification is peoples' belief that the market determines their life situation. It is much less about the actual truth of this fact, but rather the neoliberal ideology and the discourse that goes with it that shapes peoples' psychological dispositions. They are told over and over and over that the market rules, and thus their psychologies adjust to that conditioning over a lifetime. The economic structures of market capitalism and its ideological arm (neoliberalism) drastically shape peoples' psychologies, ways of thinking, and their eventual behaviors - that is, it conditions their mentality. 
"A person is not concerned with his life and happiness, but with becoming salable" $(1947,70)$. While this is a bit glib, Fromm's larger point is that people begin to conflate means and ends, or rather develop ignorance to the question of ends. The ends are assumed, like happiness for example. The question is then one of means; under the capitalistic mentality, of which the marketing social character is a substantial component, the answer is most often "through recognition by the marketplace that my choices, my existence even is valuable as exchange value." Interestingly, Fromm goes on to make a similar claim to the one made by Adorno in his culture industry thesis. Fromm writes, "[t]he most important means of transmitting the [socially] desired personality pattern to the average man is the motion picture" (71).

The importance of the marketing social character is only as important if it can be theoretically shown that there is a corollary dimension of consumer capitalism which tends to make this social character the dominant or normalized one. This is precisely what Fromm theorized in his description of the pathology of normalcy. This concept finds its roots in Fromm's most (academically) famous work, Escape from Freedom (1994). There Fromm argues, anticipating Adorno's negative dialectic, "Freedom, though it has brought [modern man] independence and rationality, has made him isolated, and thereby powerless. This isolation is unbearable and the alternatives he is confronted with are either to escape from the burden of his freedom into new dependencies and submission, or advance to the full realization of positive freedom..." (x).

Fromm's argument develops here and in the sequel book, The Sane Society ([1955] 1990), that humanity has chosen the former option exemplified in the popularity of fascism in the 1930s and 40s, the popular support for purportedly Leftist totalitarian regimes like 
the USSR and China as well as the fascistic tendencies of supposedly liberal mass culture and consumerism in Western world. Wherever people see avenues for escape from the individualized freedom won by modernity and the Enlightenment, there develops a pathology of normalcy. People want to-nay need to-feel connected to others. They require it for even a moderately psychologically healthy existence. Thus, a pathological urge to conform to whatever is deemed normal at any given point, no matter how objectively repulsive or ridiculous that trend may be. People en masse run from the demand that they think for themselves.

However, for Fromm this is not a necessary way of being for people. It is definitely a natural psycho-biological reaction to the material and social conditions of industrial and consumer capitalism, but those are not necessary conditions. "Thus the mode of life, as it is determined for the individual by the peculiarity of an economic system, becomes the primary factor in determining his whole character structure..." (Fromm 1994, 16). This "pathology of normalcy" is rooted in a psycho-biological reaction to capitalism within each individual person, but it also becomes instantiated in the "social unconscious" (Fromm $1990 ; 1962,88-109)$. The social unconscious is comprised of generally repressed elements shared by most members of a society, "the contents which a given society cannot permit its members to be aware of if the society with its specific contradictions is to operate successfully" $(1962,88)$.

The capitalistic mentality take shape in what we think, as well as what we do not think. It conditions how we behave, as well as how we do not behave. It is a productive and mystifying force. The result is that we think and behave in certain ways and we end up unaware of the sociality of the origins of that behavioral mentality. It is the social- 
psychological internalization of a self-disguising and self-justifying ideology. The most pernicious example of this internalization is the pervasive belief nowadays "that not solidarity and love, but individualistic, egotistical action brings the best results for everybody" (Fromm [1960] 2010, 56). ${ }^{62}$

Fromm reminds us that the capitalistic mentality is also often gendered. Fromm reminds us that a number of capitalistic values like competitiveness and aggressiveness are typically associated with men, and what Western developed countries have done is allow women to control their finances, but really it has turned them into the same mindless consumers and masculinist entrepreneurs (Yunus 1999; 2007). Capitalism and markets have no morality beyond their own vapid self-justification. Markets don't care about equality; they assume it. Markets and the wage labor systems do not care whether stereotypical gender roles are perpetuated or not, their only concern is with what is profitable. If exacerbating traditional patriarchal gender roles is profitable then that is what people and firms should do. If challenging traditional gender roles can be made profitable, then that is what people and firms should do. If offensive music is profitable that is what will be created, marketed, and sold. If country songs about Ford and Chevy pick-up trucks, Bud Light, and girls in cut-off shorts is what is profitable that is what will be created, marketed, and sold. The problem is the equivalency of trucks, beer, and human beings. All of this represents the commodification of subjects, of human beings. Because capitalism and markets reinforce the ideology of individuality, the most freedom I am encouraged to exercise is to shop where I want to shop, and let other people shop where they want to shop.

\footnotetext{
${ }^{62}$ There are certain parallels between Fromm's argument and Fredric Jameson's (1981) theory of the political unconscious. It is equally likely that my own familiarity with Jameson's concept has allowed me to emphasize this somewhat implicit element in Fromm's argument (the de-normalizing of certain thoughts or behaviors leading to inactivity as opposed to simply promoting a certain activity).
} 
What people fail to realize is that they are selling themselves through their purchases (Fromm 1970).

Lifestyle expectations and highly manipulative advertising together are more often than not too much for people to handle. We can see this embodied in our sporting events: soccer (football), NASCAR, baseball, and American football (NFL). In soccer, NASCAR, and football there is an explicit and mutually reinforcing merger of competition and advertising. We are expected to embrace competition and advertising reinforces that. In sports, nearly everything is covered in ads. There are ads on TV during timeouts. There are ads all over the stadiums. In soccer there are ads on the jerseys (in American football the only ads on the jerseys are for the teams, which are products in themselves but also the sports apparel company who made the jersey, like Nike or Adidas). In NASCAR the cars themselves are covered in ads; that is actually how the cars are referred to by the commentators (e.g., the Home Depot car). The intersection of our norms, our beliefs, our behaviors, and our economic structures is hard to ignore when it is presented to us, but in our everyday life we fail to see precisely that.

Expanding on this argument Fromm tells us we tend to want to possess our lives instead of living them. We develop an obsession with lifeless things. We come to value these lifeless things over our own lived experience or even the actual lives of others. This is what Fromm refers to as the necrophilic tendency of the subjects of modern capitalism. This character trait is Fromm's reformulation of Freud's death instinct, one of the potential primary instinctual drive of a person (the other being the life instinct, or what Fromm turns into "biophilia"). "Necrophilia in the charactereological sense can be described as the passionate attraction to all that is dead, decayed, putrid, sickly; it is the passion to 
transform that which is alive into something unalive....the exclusive interest in all that is purely mechanical. It is the passion to tear apart living structures" (Fromm 1973, 369). Necrophilia includes the love of the new over the old. Within capitalism, we prefer things without a lived history. We want the flawless. In other words we all tend to prefer a lifeless item we can thoughtlessly "enjoy." You might say, "well, competition is an activity" and it is, but it is an isolating one, one that requires the metaphorical or sometimes literal death of the opponent. Even when competition pits group and against group, solidarity is not required for "success." The ties between group members need only be as thick and last as long as they serve the ends of victory (i.e., profit). Competition is not about the process so much as it is about a destructive urge that eventually becomes possessed as a victory. What is a trophy but the commodity-form of an experience?

Later, Fromm would turn his idea of necrophilia into the having mode of existence (contrasted with a more humanistic being mode). What is it that I prefer to have? The new. We want what is new, and we want it to be ours (Fromm 1976, 72-73). The shinier the better. I'd prefer if my neighbor didn't have it. If they have one, that is almost like sharing, which conflicts with the having mode. For the having mode, at its most extreme, sharing eradicates ownership. Exclusive ownership is the ideal. The more people are jealous of your possession the better. The having mode is simply the pervasive tendency to live life passively through possessions or where all activity is oriented toward possession in some way. The having mode is a psychological-philosophical orientation towards the world which is characterized by the belief that everything worthwhile can be possessed as a physical thing, a commodity (69-73). "In the having mode, one's happiness lies in one's 
superiority over others, in one's power, and in...one's capacity to conquer, rob, [and] kill'" (81).

\section{The Capitalistic Mentality: A Critical-Theoretical Reconciliation}

As I have shown, not only do both Fromm and Adorno view historical capitalism as having immanently psycho-social components, but they actually agree in large part about the social effects that capitalism has on everyday people in their everyday lives. We have seen how Fromm himself, though much less explicitly a philosopher, embracingeven tentatively-Adorno's negative dialectical critique of commodification and mass culture. When added together, Adorno's and Fromm's theories offer a sophisticated, singular conceptualization, exposition, and critique of the capitalistic mentality. That is all regardless of the fact that their work approaches this phenomena with different language, different emphases, and from slightly different academic traditions.

The capitalistic mentality is the product of the capitalist relations of production that found their first thorough exposition in the work of Karl Marx, combined with Freud's understanding of the unconscious (here represented by Fromm's work). This combination was first expounded by early Freudian psychoanalyst Wilhelm Reich and developed by both Adorno and Fromm - and also by Marcuse, who has been left out less for substantive reasons than by the fact that there has been plenty written about Adorno's agreement with Marcuse's interpretation of Freud in a Marxist context. If one has any doubts about whether the capitalistic mentality represents a generally coherent and empirically verifiable concept, Marcuse's work and the scholarship engaging with his conception of the onedimensional man and the ideological import of consumer culture as a counterrevolutionary 
force would be the next best place to turn. Marcuse's potential contribution aside, let us recap what I mean by the capitalistic mentality based on a combination of Adorno and Fromm building off of Marx, Weber, and Lukács.

The capitalistic mentality combines Adorno's critique of identitarian thinking, reification, the culture industry, and fetish character with Fromm's theory of social character (primarily the marketing social character and his critique thereof), the pathology of normalcy, necrophilic tendencies, and the having mode of existence. The capitalistic mentality is a psychological, behavioral disposition that tends to permeate capitalist societies. It is based on commodity exchange, the alienation of society stemming from the wage-labor relationship through the development of an accumulation-oriented and consumption-based socioeconomic system we call "capitalism."

Though Adorno does not offer his own concept that is comparable to Fromm's concept of necrophilia (or the converse of biophilia), we can certainly evince a parallel between Adorno's critique of German existentialism — and Heidegger in particular—and necrophilia, in Adorno's Jargon of Authenticity (1973). Adorno's verdict on Heidegger is that the latter's political association with Nazism was not coincidental in regards to his theoretical oeuvre. Rather, Adorno excoriates Heidegger's concept of being-towards-death and the broader notion of Dasein, for their, in Fromm's language, necrophilic character. There is a near-obsession with death in Heidegger's work, especially death as something that provides a source of meaning, that is complicit with the philosophy of Auschwitz and the politics of the concentration camp - which themselves are the logical outgrowths of the rationalization of society and the historical evolution of the capitalist mode of production. The capitalistic mentality can thus be characterized as a kind of pseudo-existentialist 
necrophilia, where living and life are devalued in favor of death, decay, and consumptive materialism (in the everyday, non-philosophical sense), even if always hidden behind a discourse of meaningfulness and activity. The capitalistic mentality is a sociallyconditioned listlessness embroiled in relations of production, which demand rote, mindless, active consumerism as a substitute for actually creative love and appreciation of life.

The primary convergence of Frommian and Adornoian thought is in the concepts of the marketing social character and identitarian thinking. Under capitalism, people identify their labor with the wage they receive. The consumer identifies their value as a person with the expensiveness and exclusivity of the products they are able to buy (especially compared to that of their friends and neighbors - and even family members). The subject of capitalism in the twentieth and twenty-first centuries further identifies their worth as a human being with their overall success financially and personally; where personal success if defined by how big your house is or how attractive other people think your spouse is compared to the shallow norms of our popular culture.

Read through Adorno, we can see Fromm's distinction between having and being as a distinction between identitarian thinking and non-identitarian thinking as we saw earlier with the association between identitarian thinking and the marketing social character. Recall according to Fromm the having mode of existence is characterized by the unity of possession and lively meaningfulness, with the latter being destroyed by the shallowness of the former. It is really the reified belief in (or perhaps unquestioned assumption of) the identity of things, commodities, possessions and life, meaningfulness, and self-esteem rather than merely the existence of thing, commodities, and possessions. In fact, Fromm and Adorno offer very similar "cures"- beyond mere palliatives - to their 
respective diagnoses: therapeutic demystification in the form of a novel re-orientation towards a radically thoughtful living, a biophilic, productive, orientation towards being imbricated by negative dialectical thinking. Beyond mere palliatives, the alternative to the capitalistic mentality will be addressed more thoroughly in chapter four and in the Conclusion.

We can see similar, more empirically-oriented arguments in the work of Fromm and Adorno with regard to the capitalistic mentality in terms of the commodification of culture. Much was discussed earlier on this, so I simply here want to re-emphasize the theoretical compatibility between Adorno's culture industry thesis and Fromm's argument against consumerism. Both theories argue that capitalist societies center around the commodity form which itself permeates increasingly diverse layers of that society. Art, music, and more and more forms of culture are eroded by the demand of capital that cultural products appeal to the lowest common denominator or at least be marketable (and thus made artificially desired by through advertising) to as many human beings as possible. There is no regard for quality. Quantity is the coin of the realm. We are psychologically manipulated by advertising and media, to the point of pathology. Commodification becomes the norm. There is no imagination beyond commodification. We are socially conditioned to consumer the products of the mass culture industry. The correlatives of mass culture and rampant consumerism are further hallmarks of the capitalistic mentality.

Beyond the specific characteristics of the concept of the capitalistic mentality is the underlying logic and empirical evidence that our thoughts, behaviors, and beliefs are deeply and pervasively conditioned by our social circumstances. ${ }^{63}$ What Adorno and

\footnotetext{
${ }^{63}$ In addition to the roots of this idea with regard to economic systems in Marx's work, very recent social scientific theory has offered compelling injections of neuro-biological studies into the physical mechanisms
} 
Fromm are describing when looked at together is a psycho-social mentality conditioned by a mode of production and its respective relations of production, including the social, cultural, and political manifestations of those relations. To summarize again, the mentality of people under capitalism, the capitalistic mentality includes the predominance in people of the intersection of the following psycho-behavioral characteristics and their pathological normalization: identitarian thinking, reification, instrumental reason, pervasive commodification of all spheres of life including culture, competitiveness, a vacuous hyperindividualism, possessiveness (or having mode of existence), and an overall listlessness manifested in a neurotic appreciation of things over liveliness or human creativity. ${ }^{64}$ The

for the social influence on the human brain and conceptions of personal identity. The first is William Connolly's Neuropolitics (2002). Here Connolly explores the interconnection between social and political conditions and neuro-psychology. Second is Paul Verhaeghe's even more recent book What About Me?: The Struggle for Identity in a Market-Based Society (2014). Though Verhaeghe is principally a Lacanian psychoanalyst, his argument provides ample support for my concept of the capitalistic mentality based on Fromm and Adorno. He shows how three recent discoveries in neuro-biology prove the importance of social conditioning on the physical brain: Mirror neurons, neuroplasticity, and epigenetics (13-15). Mirror neurons allow us to - or rather intrinsically do - mirror the behavior of other humans. This is most important for babies who learn facial expressions and language primarily through mirror neurons.

Neuroplasticity refers to how the human brain changes itself in response to external social or psychological, not necessarily biological or chemical stimuli. Epigenetics is a subfield of genetics which studies how gene manifestation is altered by social circumstances. The foundational empirical fact of this entire field is that social environments actually influence our genes. As a side note, Verhaeghe also uses the term mentality in an unspecified way (her refers to the "pay-for-performance mentality" of neoliberal capitalism), but his use is also consistent with the working definition I provide at the beginning of this chapter. Other examples from a range of fields including sociology, psychology, philosophy, and political science, of how consumerism and socialized hypercompetitiveness are conditioned into children and adults in various ways, to the point of literally shaping our self-perceived identities, include: Juliet Schor's Born to Buy (2005), Zygmunt Bauman's Consuming Life (2007), Benjamin Barber's Consumed (2008), Rob Walker's Buying In (2010), and William Davies' The Happiness Industry (2015).

${ }^{64}$ Though I cannot explore this here, I believe there is a good chance that there is a masculinist bias here in regards to these traits being normalized for males (e.g., competitiveness is promoted for men but discouraged in women; women are meant to be sweet and passive etc.), some of which I mentioned earlier in regard to Fromm (1970). While I think this is historically true, it is due to the remnants of tribal and feudal norms within industrial capitalism which perpetuates patriarchy still. Capitalism has cemented those inequalities and hierarchies. Much of Nancy Fraser's and Angela Davis's respective work within the socialist feminist paradigm provides ample evidence for this. With women (as well as non-heteronormative sexual identities) becoming more publicly accepted and thus integrated into the pre-existing cogs of capitalism, we now have women being encouraged and socialized to behave "like men" (by this I mean in the ways young men have been historically taught to behave in order to be financially successful). While I cannot prove it empirically, it seems likely that many of the dimensions of the capitalistic mentality are more prevalent in those people who are traditionally defined as "men" as opposed to "women." Fromm 
final overarching characteristic of the capitalistic mentality is the conscious belief that these traits and practices are "natural." In other words, not only does capitalism produce a kind of subject who unconsciously and semi-consciously thinks and acts in certain ways, it (re)produces conscious ideological principles which de-historicize these very traits, deeming them natural and unchanging. For example, the capitalistic mentality not only includes reification (as a kind of mystification of our true social relations or forgetting the incompletenesses of identitarian thinking) but also a very conscious "remembering" of the naturalness ${ }^{65}$ of aggressive competitiveness. We not only fail to realize precisely how competitive we are or why we are that way, if pushed we will assert the naturalness and our preference for a competitive society. We not only practice various kinds of unfulfilling hyper-individualism, we also believe that our hyper-individualism is natural and desirable. We not only practice a self-harming (necrophilic) drive for profit, money, and things but this drive seen as natural and desirable. Partially composed of an internalized ideology, the capitalistic mentality includes, in the words of Slavoj Žižek, "unknown knowns." Unknown-knowns are things we know but we don't know that we know them or have forgotten that we know them; in other words, a kind of epistemological reification. In the

explicitly states in To Have or To Be? (1976) that this notion of equality (turning women in the same alienated, insane subjects of capitalism as their male counterparts) is extremely misguided. He argues throughout his work that men shouldn't desire this, so why should we think it's a good idea to encourage women to follow suit? In Fromm's work on matriarchal societies he goes as far as to speculate that values, behaviors, and ways of life which are historically associated with "women" and "women"-led societies actually serve as an anti-thesis to the patriarchy-reproducing, masculinist practices of capitalism (Fromm 1970). Though there are some deeply essentialist aspects to this part of Fromm's work (contrary to the generalized claim levelled by anti-humanist post-structuralist claims that his entire body of work suffers from this error - a claim that is only somewhat true, exaggerated, and misleading), I believe if we give a favorable reading and look to the values and practices Fromm's conception of matriarchy and femininity refer to, we will see that these practices can be judged positively without maintaining his occasional essentialist association of them with the "female" subject (Durkin 2014).

${ }^{65}$ Naturalness in the context of capitalism is identical to normatively desirable, which is a false, unsupportable identification which is pervasively reified. 
case of the capitalistic mentality, specifically what is forgotten is the historical social relations which (re)produce and normalize these ideas and their behavioral manifestations.

\section{The Capitalistic Mentality in Everyday Life ${ }^{66}$}

What follows sketches a series of ways of seeing the capitalistic mentality in our everyday lives and cultural practices. Here we will look at the reified possessiveness of our approach to vacationing, the existence of Black Friday and all that comes with that incredible "holiday," and finally we will look at our charitable impulses. These examples are not meant to be comprehensive. They are not meant to convey every aspect of these practices that are capitalistic, nor are they the only examples of the capitalistic mentality in our everyday culture. Many other examples are given throughout the previous sections. The examples here may be somewhat exaggerated. The purpose of such exaggeration is to suggest that the actual capitalistic mentality is often difficult to pinpoint empirically. We see its effects. We see the perpetuation of capitalism and its norms. Again, let us recall Adorno's invocation that when it comes to psychoanalysis, there is truth in exaggeration $(2005,29) .{ }^{67}$

Under capitalism, what is a vacation (besides a distant fantasy for most people)? Whether in its real or imagined form, a vacation is a trip that people take for the purposes of enjoyment, to break away from the banality of their everyday lives or to see a part of the

\footnotetext{
${ }^{66}$ These sketches, inspired by Adorno's playful, aphoristic, experimental style in Minima Moralia, are less technical than the arguments made in previous sections, but provide an illuminating foundation to my application of the concept of the capitalistic mentality to cosmopolitanism in the next chapter.

${ }^{67}$ In Café Europa by Slavenka Drakulic (1999) we see an interesting depiction of how the capitalistic mentality ends up permeating so-called "post-communist" societies in Eastern Europe. Though there is not space to delve into them here, they provide ethnographic evidence and support for the globalization of this mentality, beyond the autoethnographic examples rooted in my personal experiences in the US provided here.
} 
world they haven't yet experienced. The problem is how we behave during the vacation. This is where we see the capitalistic mentality most clearly. First, we often identify the place we are going as a tropical paradise, regardless of the fact that this is a home to other people, in most cases these other people are in extreme poverty (Jamaica is a good example but far from the only one). The poverty is largely hidden from the vacationers (who wants to see real people with real problems while they're on vacation?). We are able to "enjoy" our reification in peace and quiet. Second, what is a vacation if you don't bring home a keychain or magnet or t-shirt with the name of the place you were on it? We also feel compelled to take 6,000 pictures of everything on our vacation. One or two pictures would be reasonable to serve as a reminder of the incredible experiences you had on that vacation, but that is not really the purpose they serve. First of all, if you are taking that many pictures, your vacation probably mostly consisted of the experience of taking pictures. Secondly though, the urge to capture everything on your vacation is the drive to possess the experience. We want the pictures and the key chains and the t-shits because the capitalistic mentality identifies meaning with possession, not fleeting profound experience among friends, family, and significant others (unless of course you can take a picture of itperhaps you can even get one of those key chains where you can put a picture inside of it!). Even when my Dad used to go on vacations without me, he would bring me back a t-shirt, as if he could transfer his experience to me through this thing.

Let us look now at our shopping habits, the pinnacle of which is Black Friday, the ostensibly "best shopping day of the year." 68 A new meaning for Black Friday must surely

\footnotetext{
${ }^{68}$ Here's another good example of identitarian thinking: is it just the best shopping day of the year, or is it also the worst shopping day of the year? For some, it is clearly the worst day of their whole lives - because they end up dead. Or worse, they have to shamefully return home bruised and empty-handed having failed to pry their much-desired flat-screen TV from the cold hands of an enemy consumer.
} 
be related to the fact that people wear black to the funerals of the people who are killed on Black Friday, trampled to death by ravenous consumers who transform the entrances to Wal-Mart into a less sandy version of Fallujah. People now leave their Thanksgiving dinners early because the awesome sales of Black Friday start on Thursday-Black Thursday. In previous decades, people would wait in ridiculously long lines for products they have slightly older or inferior versions of at home. These are not thousands of people waiting for their first laptop or first flat screen TV ever. They are waiting for the very slight chance of getting a slightly better version at a reasonable price (slight chance because most stores only carry a few of these "loss-leader" items).

This is tame compared to what has begun to happen over the past several years. In the past there were often fights between customers over the last TV or toy, ${ }^{69}$ but what is recent is that people are literally murdering each other to get into these stores, and mostly unintentionally it seems. Mass crowds are rampaging into the stores as soon as the doors are unlocked, and the slower gazelles are getting trampled to death. Let me repeat, these people are not dying so that other people can get a product they would otherwise never be able to have (say with a year of saving their pennies and paying a bit more); they are killing others for a slightly better TV than they or their neighbors already have in most cases. The killing of innocent people does bring us closer to the true history of Thanksgiving at least.

But people are still charitable right, especially around the holidays? Well, first off, what does the fact that we are most charitable when we are at our most consumeristic say about the motivations for our charity? Žižek tells us that people are charitable to counteract or balance out their sin of excessive consumption (that is, until capitalist marketing

${ }^{69}$ See the plot of Jingle All the Way (1996) starring Arnold Schwarzenegger and Sinbad. 
specialists deviously began including the price of charity into the costs of their products (the example he often uses is that at Starbucks you can buy their "Ethos water" which donates a certain — very small—amount of money to villages in developing countries where Starbucks sources its coffee beans). We participate in charity to mitigate the deep-seated truth that we forget we know, capitalism is unjust. We are guilty and we donate so we can go back to enjoying our purchases.

Let us now look at what is being donated. One of the largest charities to receive donations during the holiday season is Toys-for-Tots. $22 \%$ of children in the United States live in poverty and that number is about the same globally for children living in absolute poverty, which is significantly poorer than being below the US poverty line (Edin and Shaefer 2015). Why do we spend so much money on toys for children? They cannot eat them, though many will try and get lead poisoning. ${ }^{70} \mathrm{I}$ am not arguing that children, whether in poverty or not deserve to have a high quality of life that extends beyond having the basic necessities of life met. Yet, is Toys-for-Tots equivalent to the Make-A-Wish Foundation designed to fulfill the dreams of terminally ill children? Is Toys-for-Tots our last ditch effort to improve the lives of children we can otherwise literally to nothing to help? No, of course not. If it were it would make a lot more sense. ${ }^{71}$ Ignoring the fact that we all know we can help poor children much more than we do, it is the normalization of the semi-conscious idea that "You know what is really sad? A kid without toys. You know how hard it is to say no when your kid was really well behaved and wants a toy, so you

\footnotetext{
${ }^{70}$ See this report from the CDC on lead in children's toys: https://www.cdc.gov/features/leadintoys/.

${ }^{71}$ You know what is more fun than playing with a toy while being hungry, malnourished, constantly on the verge of getting sick from the resulting weakened immune system? Eating three meals a day and using that fully-healthy brain to play pretend with a stick outside. My childhood was full of meals and lots of sticks. I loved some of those sticks more than my Legos (yes, I had toys too).
} 
give in because you just can't say no to that precious face? Imagine being parents and not being able to afford any toys at Christmas time." Perhaps we feel weird as adults imagining a parent having to explain to a child why Santa didn't bring them any toys, even though they were good all year. Either way, Toy-for-Tots does nothing to pull these children out of poverty. In fact, I would wager most people who donate never get beyond their guiltridden emotional motivations (and they're not even feeling guilty about the right thing, namely their own complicity in maintaining the poverty of these innocent kids). "You know what poor kids need? Well of course, the same thing I use to escape the necrophilic meaninglessness of my everyday life, why more things of course." Certainly not a different socio-economic system. ${ }^{72}$

This is all to ignore the fact that Toys-for-Tots is organized by the US military, the most grossly over-funded institution in the history of human civilization. A slight shift in the budget from the military to address poverty could more or less solve the most heinous problems immediately or, at most, in a matter of days or weeks - certainly not a long time to wait to eradicate extreme poverty. Why doesn't this happen? Because the capitalistic mentality allows us to identify capitalism with justice and freedom. It refuses society the fair chance to see the system for what it is. Our lives—our places in this vast system of structures - are reified. We fail to see how even when our charitable, altruistic impulses are just and true, they become mediated by the mystifying influence of our capitalistic mentality.

Toys-for-Tots also requires (in the interest of child safety of course) that you go to the store and buy a new toy, thus spurring the national economy. You can't simply donate

\footnotetext{
${ }^{72}$ The thing at the top of my Christmas list year after year.
} 
old toys. Similarly, Barnes and Noble does a book donation drive every year usually around the holidays as well. Here I was thinking that I could bring my old children's books, which are in very good shape to drop in the donation box. I show up with my books, and then I see the sign that said something like "Donated books, must be new, unread. Save $25 \%$ off your overall purchase if you buy a book here and donate it.” They are using charity to sell books. I'm sure the charitable donation is legitimate, but the profit-motive is never gone. They hope we ignore that, as most people do, and think “Oh wow, isn't that nice that they give you a discount for donating. What a great company." Then we feel even better about our own selfish shopping. This psychological dimension to consumerism is explored, though in a biologically reductive manner, in Martin Lindstrom's best-seller ${ }^{73}$ Buyology which purports to examine the psycho-biology of what we buy and why.

Within late capitalism, even sharing takes on a commodified, instrumentalized form due to the capitalistic mentality. This is what Gary Hall (2016) and Nick Srnicek (2016) refer to as "platform capitalism." They are referring to the so-called "sharing economy" rooted in app-based services like Uber, Lyft, AirBnB, and TaskRabbit. These apps

\footnotetext{
${ }^{73}$ There is an even deeper capitalistic aspect to this book that supports the argument presented in this chapter. There are several sources that have circumstantial yet compelling evidence that Lindstrom contracted a company named ResultSource whose sole product is getting books on best-seller lists (or reaching other sales related goals). The primary way ResultSource works is by itself purchasing bulk orders of their clients' books in order to trick the metrics used by the New York Times and other groups which produce respected "Best-seller lists." Seemingly applying his own model, Lindstrom's book used the consumer-recognized label of "Best-seller" (however it was actually achieved) in order to trick consumers into actually buying his book (see http://web.archive.org/web/20140203153636/http://www.resultsource.com/bestseller/buyology.php/). Capitalistic consumers, as argued by Adorno and Fromm, identify quantity with quality. Though the resurgence of hipsterism has allowed smaller companies to use their low-quantity production schemes as their own form of marketing strategy (whether honestly or dishonestly like Urban Outfitters). Here this is still an identification of quantity with quality, but with a negative twist; fewer is better. This trend is only new to the middle class it seems. It is well known that the wealthy have historically tended to prefer consuming things that are exceptionally rare (or inaccessible to most people because of a high price). Handbag companies like Louis Vuitton and the entire diamond industry are notorious for taking advantage of this. In these cases, the specificity of the pathology of normalcy is not that everyone has such and such a thing, but rather the semi-conscious belief that everyone would want it if they could.
} 
advertise themselves as a kind of commitmentless, bossless employment and always-oncall service provider. While this may be true to a certain degree, not only do workers who use these apps have nearly zero guarantee of income or safety protections, both the users and the workers are being exploited by the original creators of the apps. It is through the emergence of platform capitalism and the so-called "sharing economy" that freedom becomes further identical to exploitation and the entire idea and practice of sharing becomes filtered through and thus corroded by the information technologization and digitization of the capitalistic mentality.

With this foundation, the capitalistic mentality remains the mechanism for the perpetuation of liberal capitalist ideology to the point of viral hegemony (that is a hegemony that spreads through human interaction and intersubjective conditioning), which in the Marxist tradition means that the capitalistic mentality is situated in the undertheorized space between the base and superstructure. One of the great questions Western Marxists and the Frankfurt School sought to answer was why, given everything Marx theorized about the structures and effects of capitalism holding true, was there not mass revolutionary action across the industrialized world? Why still to this day are there still few calls for revolutionary post-capitalist change? I believe that the under-appreciated contributions of Adorno and Fromm when taken together point to the mechanism of the reproduction of capitalism. This mechanism is the capitalistic mentality, a concept that gives a more sophisticated and comprehensive buttress to Marx's theory of historical materialism. The capitalistic mentality is the intersection of the ideological superstructure, the economic base, and the reproduction and perpetual legitimation of capitalist relations of production. The capitalistic mentality becomes a defining characteristic, or is at the very 
least, a ubiquitous historical product of the contingent development of capitalism from the nineteenth through the early twenty-first century.

\section{Conclusion: Globalizing the Capitalistic Mentality}

What is it about their typical ignoring or assuming a reified notion of capitalism or identifying capitalism with a limited conception of markets that is so problematic to cosmopolitans in my view? I have shown here that markets are historically important in shaping the contemporary psychologies of capitalist subjects, but more deeply the fundamental dimensions of capitalism are deeply psychologically influential, even more so that their association with markets. More bluntly, simply viewing capitalism as a conventional economic system in which people merely participate in without lasting and pervasive psychological consequences is hugely problematic, and incorrect. The capitalistic mentality and its various traits are essential to the reproduction and normalization of capitalistic structures. Still, I do not want to make any claim for the capitalistic mentality as a comprehensive concept. It is not, nor could it be. It includes more and less than I have argued. There remains the mystified, non-identical, non-conceptual residue that the phrase can never contain or maintain. However, I believe the core of the

concept that I have detailed here, and more broadly the underappreciated psycho-social aspect(s) of capitalism rooted in the alienating causes and effects of the commodity form of labor embodied in surplus-value and wage labor through to its contemporary consumeristic dimension in our globalizing world, point to some very concrete contradictions between the cosmopolitan tradition, its goals, and the mentality that capitalism (re)produces and that reproduces capitalism. 
The early twenty-first century which has been characterized by many as the (or an) era of globalization. While there is ample evidence to suggest that globalization as a process has occurred previous, even prior to capitalism, but at the very least, capitalism is an inherently globalizing phenomenon (el-Ojeili and Hayden 2006). Over the past three decades plus since the slow end of the Cold War, capitalism has spread like wild fire. If we understand capitalist globalization as the vertical and horizontal spread and instantiation of capitalist structures, values, and practices, that is to say, the further entrenchment of capitalism into previously unoccupied sectors of economies and social and political life as well as to new geographical spaces, what does the argument for the capitalistic mentality mean for the world? Of particular interest, what does the combination of the vertical and horizontal spread of capitalism and the capitalistic mentality, which is an inherent component of that spread, mean for the cosmopolitan theorists I detailed in the previous chapter?

The result is a negative dialectic of global justice. Global justice becomes an almost unapproachable political project because of the capitalistic mentality, but even if it were on the table politically, the type of mentality, ethos, or virtue required for the mass implantation and support for and continual enactment of global justice programs like redistribution would not address the most fundamental harm that capitalism causes, namely its continued legitimized existence. How can we move towards cosmopolitan justice by accepting the inclusion and maintenance of a system premised on exploitation and the harms of alienation? How can we even view the necessity of moving beyond capitalism while we are consumed by consumerism and defeated by hyper-competitiveness, while our individuality is poisoned by hyper-individualism, while our freedom is aborted by 
supposedly free markets? How can we understand, never mind appreciate the viability of alternative social systems, when we foundationally accept that capitalism is the locus of humanness and freedom?

In reading Fromm through Adorno's negative dialectic we can re-emphasize the critical aspect of Fromm's thought that is too often characterized as bourgeois, liberal, or purely optimistic. In reading Adorno through Fromm, we can better see the guarded hopefulness pervaded by pessimism that characterized Adorno's thought. In an age that is increasingly pessimistic about progress, politics, and even the possibility of justice, a Frommian-Adornoian theory might be precisely what we need to challenge the problematic forces of optimism represented in neo-liberal-democratic capitalist globalization, while preserving the radical hopefulness and potentiality of a self-critical socialism. It is through the concept of the capitalistic mentality that we can uncover the contradictions of cosmopolitanism in order to dialectically resuscitate its latent emancipatory potential.

Focusing on capitalism as purely economic structures within the reductionist terminology of "markets" or the resulting income/wealth inequalities, cosmopolitanism cannot appreciate the socio-cultural interactions of capitalism with the psychology of the human beings who experience the totalizing, reified nature of global capitalism on a daily basis. The following chapter will explore those contradictions focusing on the categories of cosmopolitanism we examined in chapter one, and will aim to point towards the possible mediating role a negative dialectical understanding of the capitalistic mentality can play when thrust into the cosmopolitan tradition. For right now, I have shown is that there is a psycho-social dimension of capitalism that major theories of cosmopolitanism that have attempted to address the iniquities of the global economy have failed to appreciate. What 
comes next is to show why this impoverished understanding of capitalism is so fundamentally problematic for normative political theories of cosmopolitanism. All of this is in the attempt to rescue the discourse and actual efforts of cosmopolitanism, to make it more praxeologically sound, thus enabling it to realize its latent radical potential. 


\section{CHAPTER 3 \\ Cosmopolitanism and the Dialectical Intervention of the Capitalistic Mentality}

\section{Introduction}

On April 13, 2015 the Seattle-based credit card processing company Gravity garnered the attention of the national media by raising its lower paid employees' salaries from $\$ 48,000$ per year to $\$ 70,000$. This decision was made by Gravity CEO Dan Price after he came to understand that he had seventy employees making under $\$ 70,000$ per year, many of whom were having trouble making ends meet. Price cut his salary from around \$1 million to $\$ 70,000$ and used roughly $75 \%$ of the company's $\$ 2.2$ million in profit from 2014-1015 to pay for the raises (Cohen 2015a). The story was noteworthy enough from the beginning: a CEO was making the conscious choice to redistribute profit and his own salary for no other reason than it was what he believed was the right thing to do. He made sure to reassure his clients that none of the cost would be passed on to them. This seems to show that people can be conscientiously resistant to the capitalistic mentality that demands CEOs and the subjects of late capitalism pursue profit, accumulation, and consumer goods above all else (at least most of the time). If the story ended here, it would certainly be inspiring. However, that is not what transpired.

Gravity made national news again in July of 2015. Several employees who were making $\$ 70,000$ before the raises quit because they were offended that their colleagues received a raise for reasons other than merit (as if coming to work, working hard, and having a need is not merit). Despite Price's own promise that the cost would not be passed on to his customers and him hiring dedicated staff to handle the increased media and consumer attention, several major clients cut ties with the Seattle firm—some not believing 
the promise and others openly admitted that they disagreed with Price's perceived political statement (presumably the statement was that everyone who works deserves a somewhat fair share of the profits from the company) (Cohen 2015b). Gravity has gained some new clients who applaud Price's move. Price's brother (and legal co-owner of Gravity) disagreed. He is now suing in an attempt to reverse the move. Gravity, a company that was making millions in profit, for no rational economic reasons is now struggling to keep its head above water.

This story shows us that even a personal decision by a CEO to go against the capitalistic mentality will likely be met with harsh resistance. More recently we saw a related but different instance of the capitalistic mentality. In September 2015 Turing Pharmaceuticals CEO Martin Shkreli raised the price of a sixty-two year old drug used to treat HIV/AIDS and cancer from $\$ 18$ to $\$ 750$ per tablet, an estimated $4,000 \%$ percent increase. When asked why they increased the price so dramatically, the young CEO argued that is was ridiculous that people could cure themselves or keep themselves alive for a mere $\$ 1,000$. There was massive public outrage and eventually Shkreli had the price reduced (Johnson 2015). Though it may seem that the massive public outrage is a rejection of the capitalistic mentality that would seek to justify this price gouging in support of the profitmotive, the thing is, people still need to be able live (with themselves). In other words, the capitalistic mentality is not fully operative in every moment to the same degree. Capitalism as a system allows wiggle room for small progresses or countervailing tendencies. In this context, just because people are willing to accept the marketization of basic health care, it does not mean that most people will accept the worst excesses and inhumanities of capitalism all of the time, so long as whatever resistance that emerges or reforms suggested 
do not fundamentally challenge the existing order. The capitalistic mentality is not entirely anything goes, and we can still see in this instance the workings of the capitalistic mentality within the outrage against the price increase. What was challenged? The degree of the price increase by a nakedly greedy CEO. What was justified (by virtue of it not being challenged)? The mere practice of making a profit off of life-saving drugs. Why? Because everyone knows that without the profit-incentive, companies wouldn't innovate. One needs only to look at the vast array - and well-advertised — erectile dysfunction medications on the market to appreciate the perversity of a system that allows and incentives such a thing while systematically denying millions (billions, globally) health care. People want drugs to be affordable; they don't seem to care if they could be even more affordable. People have deeply internalized the basic logic of capitalism, and only react (and still only sometimes) when it sufficiently threatens peoples' lives.

The argument in this chapter is not that small improvements with regard to justice are impossible within capitalism. ${ }^{74}$ History has shown us that minimal progress is possible, but that the logic of capitalism allows merely that and usually only through a great deal of political struggle. Cosmopolitanism is principally a theory of normative progress and moral universality, and as such, cosmopolitan theorists of various kinds either describe the progress towards global justice and how to continue or expand that progress, or they are critical of the various ways progress has stalled and give potential strategies or guidelines for overcoming the deceleration. While there have certainly been inroads made alleviating

\footnotetext{
${ }^{74}$ Recall the working definition of capitalism used in the previous three chapters: a socio-economic system characterized by the private ownership of the means of production, the dominance of the expropriation of the surplus-value of labor through a wage, and the corollary predominance of the profit-motive, which has often included (though not exclusively so) the presence of markets (which themselves pre-date capitalism by more than two thousand years).
} 
the worst extremes of global poverty and political oppression, the world is nearly as unequal as it has ever been, and it is increasingly pervaded by a system of global capitalism that, while it can bring some people out of the worst depths of deprivation and suffering, has brought billions of people within a system that is predicated on exploitation and produces social relations that condition and normalize some of the worst behaviors latent in humanity. ${ }^{75}$ It does this while providing ideological cover under the banner of progressive neoliberalism. This chapter, which combines the arguments made in the previous two chapters, will show how capitalism and its capitalistic mentality undermine the principles of various theories of cosmopolitanism on their own terms. Even if one were not convinced by the arguments regarding immanent contradiction, this chapter will also explain how the capitalistic mentality inhibits the kind of progress these well-meaning cosmopolitan scholars call for in practice. These contradictions thus undermine the theories in a different (external) way. In several cases here, this external contradiction is the most crucial issue, because otherwise cosmopolitanism is left being a kind of well-wishing utopianism, a characterization its representatives would vehemently reject). The crux of the argument is that capitalism violates the principles of global justice by being exploitative, promoting social discord in various ways, along with cultivating a mentality of possessiveness, selfishness, competitiveness, and reified thinking that undermines cosmopolitan progress.

Why would we expect someone-who has been conditioned to think that "having" is more important than "being," that things are more important than life, and that they fully comprehend their world through their simplified concepts provided for them by the very

${ }^{75}$ On the current state of inequality, see Milanovic (2010), Stiglitz (2013), and Piketty (2014). 
same forces that dominate them - to be open to the idea of giving up what they perceive to be a large amount of their possessions, their wealth, and their ostensibly cozy world view in order to help near and distant strangers who are suffering largely beyond their line of vision - a line of vision that often extends no further than the sand or smartphones in which they have their faces buried? This is not to say that a person embodying the capitalistic mentality can never deviate from the strictures of neoliberal (or even traditional capitalist) ideology or the norms of the marketplace, but rather that these deviations are exactly that: exceptional deviations.

There are few critical theorists who have been excluded more thoroughly from discussions in international political theory and international relations than Theodor Adorno and Erich Fromm. This chapter, combining the insights and arguments developed in the previous two chapters, will make the case for their relevance to this field. Using Adorno and Fromm in combination, through the capitalistic mentality, this chapter will indicate how the capitalistic mentality - the particular way of thinking and the resultant behaviors that are typically present and normalized under capitalist systems—-represents a dialectical intrusion and practical road block for the achievement of cosmopolitan progress. Secondly, this chapter will conclude by arguing for the vital importance of a new version of, or rather vision for, cosmopolitanism, though the specifics of that alternative and the path needed to take to achieve it will come in the next chapter. This alternative will speak to a world beyond the reified and commodified social relations of the capitalist mode of production and has the potential to resolve the contradiction between the psycho-social dimensions of capitalism and practicable, sustainable progress towards a more internallyconsistent, inclusive, and realistic version of cosmopolitan global justice. 
While most of the examples given in the previous chapter are based on practices, examples, and observations deeply rooted in an American context, it is important to see how capitalism and the capitalistic mentality are a problem for global justice. Beyond simply showing that Americans are not participating in that progress or undermining it, for the argument to hold, we must be able to see how the capitalistic mentality is a global problem or at least is increasingly likely to become one as capitalism spreads. This project is predicated on the realities of the globalization of the capitalistic mentality. It is a wellknown fact that there are more industrialized and now post-industrialized countries on Earth than ever before, and the capitalist economy is now clearly the most dominant economic system. I argued in the previous chapter that the capitalistic mentality is something that intrinsically grows from the roots of capitalism and is (re)produced over time, and the globalization of this mentality has often been more intentional than incidental.

In Globalization of Nothing (2007) and The McDonaldization of Society (2008), George Ritzer shows how specific kinds of capitalist production, distribution, and consumption practices are being disseminated from the United States to the rest of the world, according to the growth demands of the logic of capital(ism) or what Ritzer calls “grobalization" (2008, 265). As an updated version of Weber's rationalization thesis, Ritzer's theory exposes how due to the drive for new markets and greater profits, companies around the world are adopting strategies oriented towards efficiency, calculability, predictability, and elite control all in support of maximal-and ideally endless - growth (2008, 13-19, 24-50, 183-185). These practices and demands mirror the capitalistic norms and behavioral tendencies that are normalized and internalized as the capitalistic mentality. 
Ritzer shows how in the example of McDonalds (which is just one instance of the greater phenomenon of McDonaldization), local changes to the menus are made to make the restaurant more culturally palatable with respect to local traditions and norms, but there is barely any difference between the systemic set-up of the architecture of the buildings or the behaviors and practices of the employees. It is not just wage labor, but it is mindless, hyper-controlled wage labor. It is not just the employees that are subject to the effects of McDonalization. Due to the efficiency demands of McDonalization, more money is able to be spent on local marketing and advertising $(2008,100-130)$. McDonalization includes the production of new consumers as well. The production of consumers and consumer demand is a necessary outgrowth of the structural demands of capitalism for new markets to profit off of. Read in this way, the globalization of McDonaldization reflects the globalization of the capitalistic mentality, if not the cementation of that mentality. The support that Ritzer's work offers to my argument regarding the globalization of the capitalistic mentality, is that he is well-outside the Marxist tradition. Within the Marxist tradition though there are three texts that offer support for this point as well, including Tony Smith's Globalization: A Systematic Marxist Account (2009), Samir Amin's The Liberal Virus: Permanent War and the Americanization of the World (2004), and Colin Cremin's Totalled: Salvaging the Future from the Wreckage of Capitalism (2015). Each in their own way, these texts elucidate how capitalism and its various dimensions (including the psycho-social conditioning and effects) have and continue to more or less systematically spread across more and more of the globe. ${ }^{76}$

\footnotetext{
${ }^{76}$ These texts are representative of the best texts within the contemporary Marxist literature on globalization that explicitly include the ideological conditioning and the psycho-social dimensions of capitalism in their accounts. For more historical and political-economic accounts of the globalization of capitalism within the Marxist literature, see: John Smith's Imperialism in the Twenty-First Century:
} 
This chapter will go step-by-step through each of the categories of cosmopolitanism detailed in chapter one and show how capitalism, and specifically the capitalistic mentality articulated in chapter two, undermines the goals of these various theories of cosmopolitanism. After going through the three categories, the final section of this chapter will then speak directly to the crucial contribution that bringing Fromm and Adorno together can make, expressing the need for an alternative to the capitalistic mentality. It is important to note that although this chapter deals with both the internal and external contradictory relationships between cosmopolitanism and capitalism (which are often the result of the near-complete lack of conversation about capitalism in these cosmopolitan theories, as was detailed in the first chapter), the lines between the internal contradictions and external contradictions blur into one another-as will be seen first in Rawls but more or less extending through the most radical instantiations of cosmopolitanism represented by Ingram (2013) and Cheah (2006).

\section{Negating Actually-Existing Cosmopolitanism}

\section{Mainstream (Liberal-Social Democratic) Cosmopolitanism}

The three more liberal and certainly mainstream cosmopolitan thinkers discussed in chapter one, Charles Beitz (1999), Thomas Pogge (1989; 2002), and David Held (1995; 2004), all suffer from similar problems when it comes to how they deal—or don't dealwith capitalism. Primarily due to their common roots in the political philosophy of John Rawls, Beitz and Pogge suffer from related issues. There are also unique characteristics of each specific theory that are undermined by a more comprehensive understanding of 
capitalism that takes into account the realities of this system. This chapter will cover those differences as well. The broadest similarity between all of these theories is their basis in liberalism and its philosophical anthropology. They offer a reified notion of the individual and individual motivations (i.e., rational self-interest). They also broadly assume the legitimacy of the various core theories of capitalism: its defining characteristic is free markets; it promotes freedom; it is compatible with democracy; and it is not inherently exploitative or harmful. It is only when something is done wrongly, people misbehave or are greedy, that problems arise. Put simply, these thinkers either don't see that they are smuggling capitalistic assumptions into their theories or they don't see capitalism as inherently incompatible with cosmopolitanism. Though it is impossible to prove definitively, it is likely that the capitalistic assumptions and oversights produce this view that capitalism is not incompatible with cosmopolitanism. As detailed in the previous chapter, the justification, rationalization, and hypostatization of the justness of capitalism has increasingly been a part of the system of capitalism through the progressively hegemonic internalization of capitalist ideology (re)produced through the capitalistic mentality.

While some of these views may have some merit — though some will be directly called into question here - at the very least, this chapter will show that they are all incomplete and incomplete in ways that actually produce immanent and external contradictions that undermine the goals that these thinkers are hoping their theories will achieve or the types of policies or practices that their theories call for. The multifaceted conclusion here is first, that capitalistic assumptions are ignored or smuggled into these supposedly neutral theories thus producing principles of justice that are tainted by the 
reification of capitalism and the capitalistic mentality, and secondly that even if the bases of these theories were actually neutral, the contradictory inclusion of capitalistic elements produce violations of the resulting principles, including the inhibiting of their actual realization. The demystification of this contradictory relationship leads to the alternative conclusion that (global) justice requires a post-capitalistic orientation. As will be the case for the other categories of cosmopolitanism as well, the most important and destructive oversight in liberal cosmopolitanism is the lack of appreciation for the psycho-social aspect of capitalism rooted in the exploitative, alienating wage-labor relationship, which, based on the work of Adorno and Fromm, I have labeled the "capitalistic mentality."

Before delving into my critique of Beitz, Pogge, and Held it will be worthwhile to take the time to examine their problematic foundations in liberal theory, specifically its initiation in the work of John Rawls (building on chapter one, these issues are more problematic for Beitz and Pogge than Held - though Held reproduces some of them as well).

Rawls tells us in A Theory of Justice (1971) that justice applies to societies and cooperative schemes (7). Rawls, Beitz, and Pogge all seem to agree that an economic system fits this requirement—hence Rawls' initial second principle of justice. The second principle of justice broadly requires equal opportunity to seek positions of power in society, and that any inequalities be to the benefit of everyone involved. When we look at the agents who come up with the principles of justice in Rawls' work, we can see that they are capitalistic from the start, regardless of Rawls' claim that they are pre-social. Behind the veil of ignorance these agents are completely unware of what kind of society they may be part of or what kinds of things will be valued. Despite their lack of knowledge about the 
substance of their identities, we know they are moderately risk-averse, utility-maximizers who seek to acquire as many primary goods ("rights and liberties, opportunities and powers, income and wealth" and even a sense of social and self-worth) (Rawls 1971, 92) as possible. Given the ideal orientation of Rawls' thought-experiment, they are open to a wide range of empirical or non-ideal criticisms, many of which have been rehearsed elsewhere. ${ }^{77}$ Despite these longstanding critiques, there is a deeper problem, an unspoken capitalistic bias in Rawls' supposedly pre-political, pre-social, pre-economic situation.

Given that Rawls' theory is explicitly ideal, why are the agents in the original position moderately risk-averse (that is, they are not exceptionally risk-averse, nor are they exceptionally risk-taking)? Risk is a characteristic of a non-ideal situation; ideally, there would be no risk. Though there are debates as to whether we have achieved true postscarcity as a civilization in the real-world, the supposedly "ideal" assumption of moderate risk-aversion and riskiness is just one example of the smuggling in of neo-classicalexplicitly capitalistic — conceptions into an ostensibly neutral political theory. The agents in the original position are risk-averse with regard to society and their accruement of primary goods, which include income and wealth, which is precisely why they demand the protections of the principles of justice — despite Rawls' claims that riskiness is not part of the calculus (Rawls 1971, 90-96). It would make no sense to want to ensure protection for something you were at no risk of not having, or not having enough of.

Next, are income and wealth things that people would actually be aware of behind the veil of ignorance? Rawls suggests they are but provides no rationale for this belief. It

\footnotetext{
${ }^{77}$ See Michael Sandel's Liberalism and the Limits of Justice (1982) for a critique of liberal personhood, Richard Paul Wolff's Understanding Rawls (1977) for a Marxist critique of Rawlsian categories and argumentation style, Carol Gilligan's In A Different Voice (1982) and Susan Moller Okin's Justice, Gender, and the Family (1989) for feminist criticisms and reinterpretations.
} 
seems obvious to the contemporary reader that people would want these things, but these terms are far from neutral. These are categories that have an explicitly capitalistic tenor. "Access to resources needed to survive and live a fulfilled life" would be an alternative wording that would still refer to the primary goods Rawls wants to include, but would avoid the bias towards capitalism. Recall that the concept of the capitalistic mentality includes the rationalization and normalization of capitalistic beliefs and behaviors. Even the language which Rawls uses to describe the original position is deeply influenced by capitalism. The supposedly neutral, general information the people in the original position hold regarding economics, there cannot be such general knowledge of economics. If there are any consistent economics theories or laws, they are always particular-of a particular kind of economy. Instead it seems that Rawls is content to neutralize and naturalize capitalist economic knowledge.

These are not just problems that come up when we look at Rawls' theory in the context of real, non-ideal social circumstances (which would immediately take us beyond an immanent critique), they go to the core of the neo-classical economic understanding of the human subject that forms the basis of Rawls' thought experiment. Rawls accepts and internalizes the normalization of the capitalistic profit-motive within his principles by viewing people as more or less inherently consumeristic, possessive, and more competitive than cooperative (hence the need for regulatory principles of justice).

There is also no principle of justice that allows for the revolutionary overthrow of a society that pervasively violates these principles. Why? This seems like a very rational addition. We have the first two principles or justice, why not include a principle of justice that speaks to their potential violation? If the agents are even minimally risk-averse primary 
good maximizers as Rawls posits, wouldn't such a hypothetical person be concerned about including a principle that would secure the first two? (Rawls 1971, 137). Similarly, why would rational, moderately risk-averse agents, even if they were unaware of different kinds of economies, not demand democratic control over the means of production as a basic right? This seems to logically follow from these agents being primary good maximizers. G.A. Cohen (2009) has made a similar argument that a rational person would not likely come to capitalism as an ideal solution to the problems of collective life.

The problems don't stop there, though. Even if we were to accept the basis and results of Rawls' thought-experiment, capitalism and the capitalistic mentality undermine these principles. ${ }^{78}$ Because of the social, cultural, and political mechanisms that reproduce the capitalistic mentality—all within the rhetoric of "free" exchange and "free" markets— how could people ever have a fair chance to evaluate whether their society actually meets the maximin principle of the greatest liberty for each that is compatible with the same liberty for others, a requirement implicated by the first principle of justice (and by the purpose of the hypothetical thought experiment). The expropriation of surplus-value and commodification of labor through wages is not compatible with this first principle. It does not allow equal liberty for all, some are exploited while others are the exploiters. Beyond this basic fact of capitalist relations of production, as explained in the previous chapter, the capitalistic mentality produced by these social relations conditions the subjects of capitalism to (largely unknowingly) conform to a consumeristic and commodified society. This conditioning and its reified reproduction erode the liberty to freely choose how one

\footnotetext{
${ }^{78}$ Rawls later says in his Justice as Fairness: a Restatement (2002) that the principles of justice are neutral with respect to where there is private property (private or public ownership of the means of production) and that the right to access to a socially-owned means of production is not a basic right, though this is asserted not argued for (114).
} 
labors ("species-being” for Marx and "creative expression" for Fromm) by psychologically driving people to associate themselves with capitalistic norms and behaviors.

Even if I could actually choose to be a CEO under fair conditions as the second principle of justice demands, the options I am able to choose between are either being a profit-driven, hyper-competitive $\mathrm{CEO}$ with a legal obligation to embody the a near-pure version of the capitalistic mentality (also known as a "fiduciary responsibility"), or I can labor under exploitative and alienating conditions and be manipulated by marketing, advertising, and social pressure to spend my hard-earned money on consumer goods. My question is, if laboring in some form or another, and consuming the products of labor are how we spend a large portion of our days, how are the conditions under which those activities happen not "basic" concerns of even the most ignorant agent in the most ideal hypothetical thought experiment as Rawls says they are not (restricting the economic primary social goods to income and wealth)? The only answers Rawls' theory could provide would be contaminated by its internal complicity with the capitalistic assumptions regarding human psychology and the definitions of primary goods.

Capitalism, which takes primary good maximization to its extreme, is barely a cooperative scheme with its relations of production and profit-drive. Laborers are compelled by systemic logic supported by the conditioning of the capitalistic mentality to become more and more competitive with one another for positions. They are compelled to view themselves as a commodity to be bought and paid for by the highest bidder. Their employers treat them as commodities, and in order to be successful within the narrow confines of capitalism, workers must internalize this perspective. 
Rawls tells us that the principles of justice embody a call for fraternity, “conveying...certain attitudes of mind and forms of conduct without which we would lose sight of the values expressed by [them]..." (105). He goes on to suggest that the principles of justice only function in a situation where there is a lack of "manners of deference and servility" (105). The capitalistic mentality is defined by various forms of servility: servility to one's employer, servility to consumerism, servility to the profit-motive, servility to the legitimacy of capitalism. When Rawls goes beyond the realm of ideal theory to tell his readers about how important a sense of justice and social solidarity is to achieving justice, he unknowingly expresses why the principles of justice, even in theory are incompatible with capitalism, given its known psycho-social dimensions.

The root of the contradiction lies in Beitz's (1999) approach to cosmopolitanism. Beitz more or less internationalizes Rawls' contradictory relationship to capitalism. For Beitz, unregulated capitalism and imperialism (the extreme form of nationalistic global capitalism) violate the consensual basis of the principles of justice. Beitz is right to point out that for Rawls, the whole point of the original position is to theorize what people would consensually agree to. Consent is at the root of Rawls' social contractarian approach to justice, and this is what Beitz hoped to be able to extend to the international realm in order to assert that principles of justice can apply beyond the domestic setting as well (117-119). Although Beitz does not specify what principles of international distributive justice might be besides that they must address the problems of dependency and resource usage within a context of enhanced political and civil rights, the problem is that Beitz ignores the fact that capitalism itself promotes uneven geographical development (to use Harvey's phrase) and 
where it spreads it must condition local populations to behave capitalistically (Harvey 2014, 146-163).

Even if resources were used and shared in a more egalitarian manner, from a nationstate perspective, why would these principles of justice not delve into the conditions of labor and consumption beyond the use of the basic resources themselves? Beitz argues that emerging economies should not be made, in a manner reminiscent of colonialism, dependent on developed countries. Why should any country, group, or person be beholden to a global economic system, which harbors exploitative, alienating practices that they did not consent to? Even if the products and profits of labor, production, and consumption were more equally shared between countries — and Beitz is right to say that this is a problem that needs to be addressed based through an international application of the principles of justice - what would remain are basically the same capitalistic societies we see in the rest of the developed world, merely lacking massive amounts of extreme poverty and the worst authoritarian political conditions.

These international principles of justice would need to speak to the question of consent in the context of the normalization and naturalization of the capitalistic mentality. Beitz's work leaves little space for people to address the question of consent with regard to the entire global economic system itself. In fairness, and this is the takeaway point, such questioning and resistance to the nonconsensual nature of global capitalism and its capitalistic mentality is not at all inconsistent with Beitz's overall argument.

As with each of the theories of cosmopolitanism that will be addressed in this chapter, there is a more practical problem (and this is less of a critique of Beitz-given his still mostly ideal-theoretical perspective - as it is a broader point about any practical 
attempt to use his theory as a guide for political, economic, and social progress globally). If we accept that the capitalistic mentality exists and is more powerful the longer a people have been subjected to capitalism, why would we think that the spread of capitalism could coincide with a call for greater justice on the part of the people in power, both nationally and internationally? Why would people who are increasingly concerned with consumerism, possessiveness, and competitiveness all within a deeply reified system even consider the injustice of the fundamentals of a system they have been conditioned to believe in (and materially benefit from)?

Even with the limited changes Beitz (and Rawls) imply are required by their discussions of the principles of justice, why would those who benefit from this system the most, driven by the profit-motive, who believe in the fairness and liberty of exploitative and alienating wage-labor practices ever make any significant changes to the global system that enables them to maintain their status and power? Are we to believe that moral argumentation and pulling on the heart-strings of elites is going to be anything but minimally effective? Again, there are always exceptions, but one need look no further than some conservative American Catholics' reactions to Pope Francis, members of the UK Labour Party's reactions to the election of Jeremy Corbyn, or the political campaigning of Hillary Clinton and the core of the Democratic Party (and its wealthy donors) against Bernie Sanders to see the guttural resistance to even minimal changes to neoliberal capitalism and by extension to the goals of cosmopolitanism-goals that when taken seriously, rightfully should conflict fundamentally with capitalism (Pedroso 2015; Seymour 2015; Schulte 2015; Williamson 2015). 
Perhaps I am selling people short, but given what Adorno and Fromm argue in regards to the mystification of the exploitative nature of capitalism and its infiltration into the deepest recesses of our culture and even our psyches, I fail to see how people will simply open their eyes and see that when principles of justice are applied internationally, they must target the very core of global capitalist economy, and not just the distribution of recourses and income. It is by his continued argumentation within the confines of identitarian thinking (identifying nations/governments with all the people in a country) and capitalist categories like the modern state and international trade in general that Beitz misses the important negative effects of the capitalistic mentality on his attempt to extend the principles of justice (or the idea of formulating new principles of justice through a similar Rawlsian procedure) to the international realm. This reified argumentation undermines practical progress on issues of deep importance in Beitz's work, principally international human rights and distributive justice. This progress would take a semblance of solidarity among the people in charge of existing international institutions and the most powerful states with the people they exploit or at best ostensibly govern in the interest of though largely detached from their daily lives and concerns. Within the confines of capitalism and the capitalistic mentality, it is extremely difficult to imagine the person embodying the capitalistic mentality taking a lot of initiative, at potentially extreme cost to himself, to improve the conditions of others, especially if that means radically restructuring the global economic system.

When French President Francois Hollande promised to raise taxes on the superrich (those earning incomes over $\$ 1$ million per year) to over $75 \%$, the immediate reaction of many was to (threaten to) leave the country (a threat the wealthiest man in France, among 
other wealthy people actually carried out) (Penketh 2015). Though only a small percentage of these high-income earners did leave (largely because of the vacuousness of Hollande's promise and policy and the many loopholes that emerged), it took an avowed socialist president to accomplish that minimally redistributive policy in a single country—and the outrage that it prompted is telling for the prospects of a similar, even smaller, tax at the international level. The French High Court ruled the tax unconstitutional despite the fact that six in ten French people supported it. While certainly within the power of the High Court, we can at least see that the erosion of the tax policy was carried out through undemocratic procedures and according the dictates of the capitalistic mentality. The tax was then dropped to 50\% and only applied to companies. Still after business leaders determined to punish France by refusing to invest there, the French economy suffered (though there is little reason to suspect there was any necessary economic reasons for the damage to the economy in any structural sense), and the tax was then completely dropped by 2015 (Penketh 2015).

The problems are nary different for Pogge. Just as with Beitz, Pogge's extension of Rawls into the global realm fails to adequately take account of capitalism and specifically its psycho-social content. Pogge (1989; 2002), borrowing from the more recent Rawlsian alteration to the difference principle (Rawls 2001), argues that inequalities be to the benefit of the least advantaged — not merely to the advantage of everyone. This is an even higher standard than the one that actually-existing capitalism failed to meet in the discussion of Rawls earlier.

Not only are people obligated to not harm others in a global context, but given their current participation and benefit from the existing institutions of inequality, are obligated 
to work towards a more just system. Given the argument presented in chapter two, though Pogge $(1989 ; 2002)$ suggests the opposite, that alternative system must be post-capitalistic: it must be democratic and socialist. Pogge remains ambivalent about this question, but given the drive for profit and commodification, given the alienating dimensions of the capitalistic mentality, and given the derogation of human dignity that follows from it, this capitalist system cannot be made compatible with a cosmopolitanism that asserts the basic moral worth and dignity of human beings. The history of capitalism has shown that capitalism can accommodate some dignity of human beings, but it cannot be made compatible with the dignity of all peoples in all countries (Said 1993; Arrighi 2010; Panitch and Gindin 2013).

As I showed with Beitz and will continue to show with the subsequent theorists, the capitalistic mentality undermines the cooperative, caring behaviors and drives needed to achieve a more just world. Capitalism assumes the moral dignity of all people and asserts that its practices do not violate them. It has been shown that the freedom of capitalism is very costly and deeply coercive. You can work for a pittance wage or starve-that's freedom. You can work three jobs or your kids will starve - that's freedom. People are so busy shopping and watching TV shows only interrupted by commercials convincing them to buy more things that they hardly have any concern with global injustice at all. They are distracted by the reified society they inhabit and have inhabited for their entire lives. Pogge offers a question suggesting a very similar concern, but he asks his question in relation to global distributive justice: why don't people in the Global North care about the suffering of people in the Global South? A still prior question needs to be addressed: why don't people in the Global North care about the suffering and extreme poverty of people in the 
Global North? Our fellow citizens and the citizens of the world are our competition. "If they get a raise, I won't, and then I won't be able to get the barely improved iPhone 9 or Samsung Galaxy NoteTab Backscratcher-water-filtration system 5 mini" -or whatever the next gadget that comes out is called (Crary 2014). If the amount of time people spend thinking about justice or money is any indication, so long as the commodity-form is dominant as it must be for capitalism to continue, the capitalistic mentality represents a serious threat to global justice (Argyle and Furnham 1998; Bijleveld and Aarts 2014; Furnham 2014).

The root of this under-appreciation for the full-depth of the problem of capitalism in relation to cosmopolitanism comes down to the question of Pogge's original tripartite conception of cosmopolitanism. Though capitalism is problematic for Pogge just on those terms described above, its incompatibility could be made more explicit from the outset, and this would address the problem of practical progress as well. Pogge's conception includes individualism, universality, and generality. Lacking any solidaristic component, Pogge's understanding of cosmopolitanism remains self-defeating by maintaining a superficial compatibility with the capitalistic mentality. In order to address this lack (and the contradictions that spring from it), what Pogge's cosmopolitanism needs to add is solidarity, community, or perhaps even entirely replace "individuality" with Etienne Balibar's concept of "transindividuality." 79 In doing this, the normative thrust between the

\footnotetext{
${ }^{79}$ Though this will be explained more fully in the final section of the chapter, transindividuality is a concept used by Balibar (2014) to express the co-constitutiveness of individual subjects, communities, and nations. We are always-already and continuously shaped by others, by our families, by our society and its norms - however negative or positive they may be. By normalizing an idealized conception of the individual as producer and consumer, capitalism degrades the human experience by conditioning people to resist what is already a social fact of human beings: they are better together than they are alone. Though the term post-dates Fromm's writing by more than a decade, transindividuality is a concept that is implicit in Fromm's (1976) idea of love and his distinction between the having and being modes of existence.
} 
universality and generality of human dignity could never be made compatible with the extreme forms of individualism - like those associated with the avaricious tendencies of the capitalistic mentality — which undermine the dignity of the self and the achievement of universality and generality in progress towards justice.

The capitalistic mentality functions to maintain and increases the prominent of selfishness within societies and that selfishness is incompatible with the degree of selfcritical altruism or acknowledgment of guilt of being a complicit beneficiary of a deeply unjust global economic system. By limiting his discussion of capitalism to poverty and inequality, Pogge ends up ignoring the exploitative elements of capitalist relations of production and the psycho-social ramifications embodied in the capitalistic mentalityand thus fails to see how the capitalistic mentality undermines cosmopolitan progress.

Pogge tells us that "[b]y continuing to support the current global order...without taking compensating action toward institutional reform or shielding its victims, we share a negative responsibility for the undue harms they foreseeably produce" $(2002,144)$. Foreseeable to whom? The capitalist elites can certainly foresee them, but can the person working fifty plus hours a week? Can the shopping addict really foresee the consequences of their actions in between checking their bank account and updating their Facebook or Twitter page with life-changing make-up tips or twelve different ways to maximize your daily workout? Surely this person is still morally culpable, but in fairness to them, given the reified character of consumer-production and supply chains that maintain this kind of bourgeois lifestyle, how could this person actually foresee the consequences? They might even have wealth, but they still seem to lack the actual will to exercise any potential political power they may have (something that Pogge [2002] explicitly mentions, but is at 
a loss for an explanation). Put rather crudely, cosmopolitanism cannot succeed so long as people in the post-industrial world care as much as they do about swiping their credit card and express as little care as they do about the global damage reproduced and legitimized through each swipe.

The question remains, however, whether the original position in Rawls', Beitz's, or Pogge's uses of it, why would any rational person who was aware of the historical, contingent, socially-reproduced capitalistic mentality, choose to live in that kind of system? The agents in the original position are refused this knowledge (and any kind of knowledge of the structural violences inherent to capitalism) through the veil of ignorance, but the reader of the texts is not. From the beginning, the veil of ignorance serves a nearly identical function as the veil of reification does for the (capitalistic) reader (and subjects of capitalism more broadly). More simply, both phenomena perpetuate the inability to see one's true historical position and within the current social relations. Looking at the original position through the psycho-social conditions of capitalism (now, with knowledge of the historical function of the capitalistic mentality), we can see that people are encouraged to "choose" this system because the capitalistic mentality compels us to welcome our chains. ${ }^{80}$ Put less dramatically, the content of the capitalistic mentality includes the normalization and naturalization of capitalism and its behavioral norms (e.g., that hypercompetitiveness is natural and thus cannot be socially changed).

By conditioning us to view the capitalistic mentality as a transhistorical, natural human psychology, capitalism corrodes ethical self-reflection, the basis of genuine

\footnotetext{
${ }^{80}$ Rawls tells his readers that the actual function of the original position, the veil of ignorance, and the ensuring argument in A Theory of Justice is to provide an idealistic mechanism for people reading the book to reflect on the actual non-ideal conditions of the society they are a part of $(1971,11-17)$.
} 
cosmopolitan progress. If I believe that the capitalistic mentality is simply identical to natural, biologically determined human psychology, why would I even think to advocate for an alternative system that demanded a very different kind of psychology? It would be irrational to do so, and this is precisely what the internalization of capitalist ideology provides. It provides rational justifications to preempt the urge to look beyond capitalism, no matter how bad things get.

This question of how free we really are under capitalism leads us to the primary dimension of David Held's (1995) conception of cosmopolitan democracy. Held tells us that autonomy must be central to any understanding of democracy and thus cosmopolitanism. Liberal capitalism assures each person of their unique individuality and autonomy and the capitalistic mentality ensures the maintenance of that belief. You can buy Nikes or Adidas, but not having cool sneakers is an unpalatable option, often to the point of it not really being considered an option if at all avoidable. Sneakers are of course just one particular example. We can think of all kinds of clothing, cars, smartphones, or nearly any mass marketed consumer good. Consumer choice becomes identical to free-will or agency (Markus and Shwartz 2010). What exactly are we autonomous to do then? Can we labor how we choose? No. Can we refuse to comply with the dominant paradigm of consumerism and commodity fetishism? Yes, but it becomes increasingly difficult. There are at least two main reasons for this difficulty. First, we don't choose to be born into a commodified, consumeristic world. We don't choose how we're raised. We don't choose to be pressured to get a high-paying job. We don't choose the fact that a nice car and nice clothes are status symbols that determine how people view you. The second reason for this difficulty is that most people are completely unaware that this is what they are participating 
in. This is what the reification of our social conditioning is. ${ }^{81}$ We identify consumer choice with free will (Xenos 1989). We identify the choice of careers (which is still extremely limited for most people) with agency, but we cannot choose to not have a job. ${ }^{82}$

How would transnationalizing democratic institutions affect this? That question isn't meant to exclude the process of progress questions that were brought up in regard to Beitz. Those issues apply here as well. How would the capitalistic subject get the fortitude to resist their psychological conditioning enough to value transnational democracy more that shopping or profiteering? Maybe there is a way now, and I am just not seeing it. Regardless, Held completely ignores the possibility that this psycho-sociality of capitalist economic systems is even a relevant question.

Even if Held is right that this transnational democratization would make a huge difference in the politics of everyday life, the question is how that democracy would function differently than it does now? The capitalistic mentality is an alienated psychology. If we accept that any notion of democracy that exceeds a bare-bones plebiscitarian democracy requires some kind of social cohesiveness or solidarity (in other words, that there actually be "a people" who rule or are sovereign in the last instance), it is difficult to imagine how a functional democracy can be maintained alongside capitalism. Democracy is undermined by the capitalistic mentality, because solidarity is the inverse of alienation, which is a natural consequence of the capitalist mode of production discussed in the

\footnotetext{
${ }^{81}$ Althusser (1971) refers to this process as interpellation, the process by which people becomes subjects of capitalism (or whatever social system they are born and raised in), which in my combined use of Adorno and Fromm would be described as the reification of the historicity and sociality of the dominant and normalized character orientation (and the core of the capitalistic mentality).

${ }^{82}$ Marx's notion of the realm of freedom (Marx 1978).
} 
previous chapter. ${ }^{83}$ If capitalism continues to spread horizontally and vertically through to the depths of the psychologies of more and more people on this planet, why would we think we would get any different version of democracy than we have in the countries where this system and mentality have already taken root? Again, maybe there is a path forward within Held's approach that I am simply missing, but given that he gives no depth of consideration to the psychological bases of democracy and capitalism, it seems unlikely that there isagain, at least not within his framework as it currently sits on the page.

Even if we take Held's understanding of capitalism as a market economy, Fromm's contribution to the capitalistic mentality is enough to show us that the marketing social character (which overlaps greatly with the capitalistic mentality) is enough to undermine Held's political solution to the problems of global injustice. We need not accept the idea (as Held rejects it) that the state is merely the committee for managing the common affairs of the bourgeoisie as Marx defined it, to see that capitalism and democracy-consumer capitalism especially—do not mix. Held seems to agree with Marx —-though Marx thought this was a reason to revolt whereas Held finds cause for praise—stating, "governments must take action to help secure the profitability and prosperity of the private sector...A government's policies must, thereby, follow a political agenda that is at least favourable to, that is, biased towards, the development of the system of private enterprise and corporate power" $(1995,247)$. What Held then fails to do is show why this social fact is actually normatively desirable or even practically necessary. Based on the kind of

\footnotetext{
${ }^{83}$ There is a great deal of literature within political theory that indicates that some form of social solidarity or civic culture is necessary for a healthy democracy. The most prominent examples include Rousseau (1978), Barber (1984), de Tocqueville (2000), and Putnam (1993; 2001; 2004). Though with these thinkers, as with the cosmopolitans discussed in this project, there is an assumption that enough solidarity is possible within capitalism to make capitalism at least minimally compatible with democracy.
} 
cosmopolitan social democracy Held calls for, the reader is left completely confounded as to how any kind of even minimal welfare state is compatible with a government that privileges the private sector.

Held claims to want to dismantle neoliberalism, yet leaves the substantive and normative aspects of neoliberalism — which correlate highly with the market aspects of the capitalistic mentality_intact. Absent a more solidaristic ethos, cosmopolitan democracy has about as much chance of being just as the plutocracies that Western democracies have devolved into (if they were ever anything else).

\section{Habermasian or "Critical" Cosmopolitanism}

After the fall of the Soviet Union the "end of history" was declared by many, most notably by neoconservative turned neoliberal Francis Fukayama (1992). According to Fukayama, the end of history was supposed to mean the unquestionable historical success of liberal capitalist democracy against the nefarious forces of Soviet communism. From a Left position, in a collected volume appropriately titled After the Fall: The Failure of Communism and the Future of Socialism (1992), Jürgen Habermas contributed an essay that more or less called the socialist vision associated with Marx a lost cause, and that the best hope that the Left has of any semblance of an emancipated, non-exploitative society must come in the form of a regulated capitalist market economy and the democratization of all levels of politics (36-39). We should hardly be surprised to find this acceptance playing an important role in the rest of his work as well — as it does in the thinkers building on his work, namely Benhabib and Linklater, who will be discussed shortly. In this section, I will show how the capitalistic mentality internally undermines the potential for 
communicative action, and therefore that capitalism as a system is unethical (in that it violates the principles of discourse ethics) and more importantly prevents progress towards the normative horizon of the ideal speech situation. Before tackling those arguments, we will begin by exploring Habermas's thesis about the colonization of the lifeworld.

The core question with respect to Habermas's warning of the potential colonization of the lifeworld by the logic of systems (the bureaucracy of the government or the profitmotive of the economy to put it simply and in a strictly contemporary context) discussed in chapter one, is how capitalism, even if Habermas is right that it is essentially a system distinct from the lifeworld of culture, family, language, and ideally non-instrumental social interaction, could ever just be that? Even if at its roots capitalism is merely an instrumental system with a logic geared towards the efficient meeting of human needs and wants, how can the psychology needed to maintain the particular labor, production, and consumption demands of capitalist enterprises ever be restricted to our behaviors within that system? Where is the evidence that people are so easily capable of not letting the psychological motivations for work and consumption infect other aspects of their lives? Why are we to believe that the behaviors and attitudes associated with systems won't infiltrate the lifeworld? In practice, as we saw in the last chapter, it doesn't seem like it happens regularly. Shopping becomes a social activity. Politics is reoriented towards the profitability of corporations. Corporations become identical to people in order to better protect their right to unlimited property and use of money to make sure political leaders keep their eyes trained on the bottom lines of corporations and financial elites as opposed to the true needs of their supposed constituents. 
The threat of the colonization of the lifeworld is one of the key issues facing modern societies; if the system logic infects the lifeworld, democracy is severely hindered (Habermas 1998). What Habermas is wrong about is that capitalism could ever just be a bounded system, that if it functioned "correctly" would not colonize the lifeworld through its incessant drive for the production of new profitable commodities and the corollary demand for new markets to sell these new things in. The colonization of the lifeworld is inherent to capitalism precisely because of the capitalistic mentality. The capitalistic mentality is totalizing. There is no clear off switch. Though there are moments for noncapitalistic impulses, these are exceptional. All of this happens more perniciously when the process is mystified. The capitalistic mentality is (re)produced by the labor practices and consumer demands of capitalism, and at the same time it normalizes whatever belief or behavior is necessary to ensure profitability (e.g., possessiveness, competitiveness, conspicuous consumption/consumerism, hyper-individualism, etc.). The naturalization and normalization of these psychological traits over time reifies the colonization of the lifeworld that is inherent to the essential elements of the capitalist system, that is, what makes capitalism capitalism.

The question that Habermas never answered was why he thought it was possible for instrumental reasoning to be contained within systems without inherently infecting the lifeworld. For Habermas, the so-called "colonization of the lifeworld" is a latent possibility within capitalist political-economies, but he explicitly theorizes that the colonization of the lifeworld is not automatic within capitalism. Human psychology is complex and we are capable of immense cognitive dissonance and compartmentalization, but those processes struggle against our social conditioning and the specific demands of what constitutes 
normalcy that our society presents to us, including the pressures it provides for us to meet them (at least if we want to be "successful")(Fromm 1955). In fairness to Habermas, he is quite clear about how capitalism has colonized the lifeworld, but if he viewed this as an inherent aspect of capitalism, why would he suggest that merely regulating capitalism and instituting redistributive taxation was enough to maintain the value rationality and deliberative consensus-building logics of the lifeworld?

The best explanation I can offer is that Habermas failed (and continues to fail) to appreciate the interconnection between the fundamentals of wage labor, surplus-value, the profit-motive, commodity fetishism and the capitalistic mentality (or the content of this concept which is found in the work of his earliest intellectual mentors), or he is a lot more sanguine about the capacities of the human mind to compartmentalize than I am (or than Adorno or Fromm are). At the very least, Habermas's argument is extremely vague when it comes to how, despite everything we have seen from capitalism over the past 200 years, we can still say that is it possible for capitalism, with its psycho-social elements, not to colonize the lifeworld. In order to expand (which it needs to do in order to survive) capitalism must be able to commodify more and more aspects of human existence, and as we saw in the previous chapter, that is precisely what it does.

For the very same reasons, I fail to see how communicative action (which is the action suited to the lifeworld) is compatible with capitalism. It is worth saying a bit more about communicative action before proceeding to the critique. Habermas's theory of communicative action is based on his earlier work on universal pragmatics, a theory about the assumptions in language that are required in order for communication-and more importantly, understanding - to be possible. Universal pragmatics suggests that the goal of 
communicative action is to "bring about an agreement that terminates in the intersubjective mutuality of reciprocal understanding, shared knowledge, mutual trust, and accord with one another" (Habermas 1979, 3). This all requires a shared language or at the very least translatable languages where the meanings of concepts are similar (3). The universal pragmatics of communicative action also suggests that all those to whom my speech is relevant are potential addressees and warrant inclusion in the speech situation in which my utterance was made. This final point speaks to one of the core aspects of discourse ethics.

Violation of the principles of universal pragmatics leads to the incomprehensibility of language, and specifically the incomprehensibility of speech-acts, like "I promise." If I do not mean what I say, I am not conforming to the telos of language, namely mutual understanding. This is why the concept of lying refers to a non-normative behavior; it undermines communicative action. Similarly, statements like "I am currently lying” or "I am not speaking" lend support to the idea of universal pragmatics because these utterances make no sense. They are performative contradictions: statements that due to their locutionary content (and illocutionary intent) undermine their own comprehensibility. Deception and performative contradictions are thus excluded from the realm of legitimate discourse, and point directly back to the inferred principles of universal pragmatics. It would be illogical to suggest that someone reached agreement through deception or through confusion (Habermas 1990, 80, 87). Not for capitalism, though (and this is something that Habermas would agree to - which is why he theorizes the systemic logic as one that is distinct from the value logic of the lifeworld, the realm of communicative action). 
Communicative action requires that I speak to others in a way that they can understand. If this fails, I must rephrase my claim in a different way, again so long as the purpose is mutual understanding (Rehg 1997, 135). This requirement refers to what Habermas calls the "inherent reflexivity" of language (Habermas 1979, 42-43). This is not to suggest that deception is not a potential use of language. It certainly is, but it is not within the bounds of communicative action. Deception, compromise, and coercion are all aspects of strategic action. Strategic action is defined by the elevating of one's own interests above others and the ungrounded use of language for those purposes. Habermas is explicit about all of this, but what he avoids confronting is how communicative action can coexist with a system with an inherently expansive logic that promotes a mentality that is completely antithetical to the communicative demands of a distinct lifeworld which would require that this strategic, capitalistic mentality cannot extend into.

Capitalism functions by reaching through the television, through the football game you're attending with your kids, through your trip to the movies, or your everyday tasks at your job, to convince you however explicitly or subtly it can, to buy things or to continue going to work every day so that you can buy all of these things - or perhaps put it on a credit card and then go to work at two jobs to pay it off-no matter how menial or unfulfilling or socially unnecessary the tasks at your place of employment are. The logic of capitalism is completely uninterested in the boundaries between system and lifeworld. If it was not expansionary, if it was not exploitative, it might respect such boundaries, but even with laws that could restrict consumerism, advertising, and even profiteering, the capitalistic mentality would still remain. Even if the government takes $50-75 \%$ of your income, there is nothing stopping you from getting motivated to make even more so that 
there is more left over after the government takes its share so you can buy more things that you can continue to identify with your self-esteem.

Because the principles of communicative action are the basis for discourse ethics (consensual, coercion-free decision-making of all those affected), we can conclude that by virtue of its exploitative nature and hierarchical labor practices, as well as the coercive infestation of the lifeworld, capitalism is unethical as well. The implications for this in regard to Habermas's version of democracy and cosmopolitanism are crucial. Once the lifeworld is infected by the capitalistic mentality (the psychology of the systemic logic of the capitalist economy), the democratic possibilities of the public sphere are eroded as well. Without public spheres, Habermas's entire conception of discourse-theoretical democracy becomes untenable in practice and utopian in theory. Without genuine public spheres across national-boundaries, the possibility for the ethico-democratic public discourse needed to produce legitimate global domestic policy in any key area is deeply suspect. While the commodification of labor, politics, and the global environment persist, democratic public spheres capable of genuine progress on issues of global justice against the interests of the entrenched elites seems grossly, nearly delusionally optimistic.

The globalization of the capitalistic mentality is corrosive to democratic will formation, the core of Habermas's notion of sovereignty and political legitimacy. If this is taken at the global level to merely mean legitimation through human rights, a conception of human rights that allows for exploitative labor practices and the commodification of human life (among everything else), is hardly a conception of human rights worth offering as a mechanism for ethico-political legitimation. Compromise — generally regarded as one of the cornerstones of international diplomacy and transnational relationships - is a 
dimension of strategic action. So is lobbying, a favorite practice of the transnational capitalist class to ensure favorable tax treatment wherever they are planning to do business (Robinson 2004). Habermas has yet to connect the dots as to how capitalism can be made compatible with the demands of communicative action, if indeed Adorno and Fromm were correct from the beginning that capitalism is itself more or less defined by strategic action practices.

No matter how much we regulate capitalism, by the very nature of the practice of mere regulation, we are still within the realm of capitalism, and as long as we are within the realm of capitalism, we are within the realm of pervasive and dominant instrumental rationality, strategic action, and the capitalistic mentality. Communicative action requires postcapitalism (ideally some kind of democratic socialism-not social democracy), because without eradicating the strategic reason inherent to the capitalistic mentality (embodied in incentivized, normalized, and naturalized competitiveness and instrumental rationality), communicative action will remain consistently beyond reach. While certainly not comprehensively impossible within capitalism, communicative action on a mass scale is certainly not consistent with the ubiquitousness of the capitalistic mentality. My claim is not predicated on the complete impossibility of communicative action within capitalism, but simply that capitalism (re)produces conditions that are generally inimical to communicative action - beyond momentary, exceptional, and inconsistent manifestations. Regulation cannot address the social problems caused by the capitalistic mentality, nor can it prevent capitalism from (re)producing the capitalistic mentality. Capitalism and the progressive instantiation and maintenance of a lifeworld of communicative action are incompatible. Capitalism is thus unethical according Habermas's discourse ethics. 
Furthermore, the political theory on which Habermas builds these ideas is hopelessly utopian so long as these multi-level contradictions are overlooked or assumed away.

It is for all of these reasons that the extensions and elaborations of Habermas's original theory by Benhabib and Linklater, that their theories suffer as well. With that said, in each case there are additional issues that emerge when examined dialecticallyespecially focusing on the concept of the capitalistic mentality. Benhabib and Linklater are two thinkers known for their emphasis on the necessity of having certain basic socioeconomic conditions met before a discourse-theoretical legitimation process or discourse ethical procedure can happen, it is amazing how readily they accept and deploy Habermas's assertion that there is a way to exclude the instrumental, strategic, logic of capitalism from the non-systemic aspects of human collective life (i.e., the various dimensions of the lifeworld). They both speak to the preconditions for coercion-free discourse yet both fail to see how even a regulated capitalism still promotes a social psychological tendency that undermines the fabric of dialogic relations. It would only be through genuinely socialist policies and practices that the capitalistic mentality would be progressively undermined, allowing communicative action and coercion-free public discourse to occur.

Even beyond her Habermasian foundation, capitalism is additionally problematic for Benhabib, principally for her (neo-Kantian) concepts of hospitality and cosmopolitan federalism (Benhabib 2011). By principally focusing on how economic globalization affects nation-state sovereignty and limits the capacity to subject economic power (and thus exploitation) to democratic control, Benhabib ends up ignoring how the structures and norms of capitalism undermine both genuine cosmopolitan hospitality and global 
federalism (Benhabib 2004, 103-104). Even if capitalism could be subjected to democratic control while still somehow being capitalism, the capitalistic mentality maintains the normalization of capitalistic behaviors and thus people will democratically contribute to a system that opposes their fundamental needs and artificially produces unhealthy desiresalong with unhealthy social relations. Political democratization is only one part of the solution; economic democratization (social control over the means of production) must be included as well, and even still there is no guarantee of success.

Even if economic power were to be subjected to the multilevel democratic control of a cosmopolitan federalist system, if that economic power were rooted in capitalism, it is hard to imagine how different the world would be. Why would we assume that this would not further entrench the injustices of capitalism alongside very limited reforms to possibly reduce the most extreme forms of deprivation, while exploitation, alienation, and the commodification of life and ecosystem are legitimated even further? Now this is not necessarily the case, but Benhabib's approach omits any discussion of this potentiality and leaves an enormous blind spot that would make the overblown fear of global governance becoming global tyranny a reality. This is not global tyranny because of some kind of conventional political authoritarianism, but rather it is the continuation and further cementation of the global domination of the people of Earth at the hands of and to the benefit of transnational economic elites (Wolin 2010).

The capitalistic mentality even assaults the potential for democratic iterations (the communicative practices whereby people shape the contours of membership and meaning in the demos) and jurisgenerativity (the communicative practices whereby people contribute to reinterpretations of law and jurisprudence) mentioned in chapter one 
(Benhabib 2011, 112-113). These processes that shape the formation of public will and the actual boundaries of the demos itself require that people actually care about these things. This is not to suggest that capitalism prevents people from caring about the nature of democracy, but the social function of competitiveness and consumerism, which we identify with our existential search for meaningfulness under late capitalism draws our attention away from such concerns nearly minute by minute (Crary 2014). We are left perpetually underfulfilled and even if we were ever fulfilled, Don Draper would convince us we needed to buy this one last new thing, and then, then we would be even happier (Carveth and South 2010). There is always one more thing to buy. The capitalistic mentality serves as a distraction from the otherwise organic human demands for democracy that would (and still occasionally do) emerge if it weren't for the pervasive psychological distractions cultivated by the psycho-social dimension of the capitalist mode of production.

If people are distracted with the drive for the next new gizmo, they are certainly less likely to care about the shape of the demos-unless of course there is a concern that something on the political agenda would interfere with one's ability to get that next new gizmo, by say, making one's job more precarious or decreasing the likelihood of a raise due to (fears of) increased competition from immigrant labor (even if those immigrant laborers are refugees). If someone works forty-plus hours a week and is taking care of their family and is also spending more and more time shopping, whether in person or online, there is simply less time and mental energy available to consider seemingly abstract political issues like justice (Crary 2014). This increased consumeristic distraction is rooted in the fundamentally expansive (and reified) logic of capitalism and serves to reproduce capitalism, including its psycho-social dimensions. 
The competitiveness and the identification of that competitiveness with a natural, justifiable disposition and the continued reification of the historically contingent sociality of that competitiveness undermines the much more humane idealization of democratic iterations and cosmopolitan federalism with an emphasis on transnational hospitality that Benhabib offers. Cosmopolitan federalism, hospitality, and democratic iterations need to take on a radically anti-capitalistic tenor if they are going to be successful in preventing the capitalistic mentality from undermining those goals. That means cosmopolitans like Benhabib need to be more explicit about how they are going to prevent the structural forces and ideological conditioning of capitalism from colonizing the norms and behaviors of otherwise potentially democratic citizenries. At the very least, democratic cosmopolitan federalism requires much more solidarity than is compatible with the capitalistic mentality.

Benhabib's work reifies the true nature of capitalism with respect to the goals of justice and emancipation (even as utopian ideals or as normative horizons). By staying within the realm of political emancipation (to use Marx's terminology), Benhabib misses how the freedom within the system of capitalism is actually inhibited by its existence within that system. It is only by a more comprehensive call for both political freedom and freedom from the system of capitalism that we avoid the threat that the capitalistic mentality will be maintained and allowed to undermine progress at any turn. Benhabib is right to point out that many human rights laws actually include protections against the forces of capitalism (alongside protects for private property, contracting, etc.), but so long as the capitalistic mentality is allowed to be maintained within progressive cosmopolitan movements, labor protections and equal pay for equal work will never be anywhere close to enough to end the exploitative practices of capitalism itself. Market protections are 
important but insufficient. The argument is not what Benhabib claims is the "old Marxist trope" that human rights are merely an ideology designed, or at least functioning, to legitimate and reify commodity relations, though the rhetoric of human rights certainly has functioned this way quite often $(2011,122)$. Human rights are deeply important, but they must be severed from their contradictory relationship to capitalism if they are to have any global importance moving forward into the twentieth-century.

For Linklater (2011), many similar things could be said. He shares many of the same blind spots as Habermas and Benhabib, yet for Linklater they become more explicit. Here I want to focus exclusively on his most recent study on the problem of harm. My argument with Linklater here is rather simple: capitalism is a kind of harm, the capitalistic mentality is a kind of harm, the capitalistic mentality as a kind of harm leads to the (re)production of other kinds of harm, and this way of thinking and behaving undermines the civilizing processes and cosmopolitan harm conventions that Linklater theorize serves the goal of progressively decreasing the various versions of harm present in world politics.

First, capitalism is based on exploitative labor practices, regardless of whether they take place in a third-world sweat shop or in a first-world auto plant (egregious working conditions is a dimension of harm that Linklater mentions) (2011, 52-75). It is also the reification of that exploitative relationship that functions as a social harm. It is a violence against the truth which is a harm because it perpetuates the exploitation even furtherthrough legitimation (or rather, the perception of legitimation) the harmful practices continue. By expropriating the surplus value produced by laborers under the conditions of the realm of necessity (where labor is presumably conducted under the belief that it is required to survive: we need to make a living to buy food, water, and shelter for ourselves 
and our families) workers are being both stolen from and lied to within a rhetorical paradigm that legitimates both.

Linklater goes on to discuss psychological harms (bullying, name-calling, racism, misgendering, and other forms of intentional and unintentional social misrecognition) (2011, 22, 40-51, 95-107). Noticeably absent from the discussion of the harms of exploited labor are the facts that this exploitation is integral to the capitalist mode of production as well as that it necessarily produces alienation. We are inhibited from laboring as we choose. We are inhibited from laboring creatively. We are inhibited from owning the products of our labor. We are inhibited from viewing our fellow laborers in solidarity as fellow workers (the same for consumers - we see others as potential competitors for the item I want in that color or that size, or at the very least they better not try to get in front of me in line!); instead laborers see each other in competition. In service or white-collar careers, the practice of networking through events or sites like LinkedIn dedicated towards forging professional relationship specifically for personal advancement, encourage workers to view others as means to an end - the end of personal gain and wealth accumulation. We are inhibited from viewing ourselves as part of nature or nature as something to be appreciated as opposed to consumed. We are coerced into this alienated existence through the labor practices central to the capitalist mode of production.

Beyond the coercive element, though, there is actual psychological harm as well. In work that could be considered a more social-scientific update to the work done by Fromm in The Sane Society (1955), Wilkerson and Pickett's The Spirit Level (2009) examines the harms of inequality in various societies with a number of sophisticated empirical and statistical models. Though inequality is not my focus here (and is certainly a 
kind of harm well-addressed by Linklater [2011, 54-68]), there are interesting implications in this book that speak to the mental and physical harms caused by consumerism and competitiveness-embodied well with a bumper sticker they quote in the opening to their chapter fifteen: "The one who dies with the most toys wins" $(2009,215)$. The more unequal a country is, the higher rates of consumerism there is (223). "As inequality increases status competition [which has an inverse correlation with happiness], we have to struggle harder to keep up" (222). The problem with competition is that it increases stress and overall cortisol levels in a society. Increased cortisol levels in a society has been shown to cause measurable physical health effects like heart attacks and it causes mental distress as well, including a propensity for violence (37-39).

Competitiveness may spur (sometimes unnecessary) innovation, but it is also deeply socially destructive. Competitiveness is literally biologically and socially unhealthy. Instead of acknowledging the social influences that make us unhealthy, sad, and violent — which we are inhibited from doing so by the various mechanisms of reification we experience — we take drugs, legal and illegal ones (2009, 66-72). It seems possible, as Fromm (1955) suggested, it is very possible and in fact likely, that a radically different social order, like democratic socialism, would be much more effective at reducing these problems than any new selective-serotonin reuptake inhibitor (SSRI) could ever hope to be, but SSRIs are a lot more profitable than democratic socialism would be.

It is not just the issue of harm. The characteristics of the capitalistic mentality actually interfere with peoples' ability to perceive these harms. Reification of the social impetus to be extra competitive, to be extra possessive, to identify one's value as a human being with one's success in the commodified personality market (to use the Adornoian 
reading of Fromm from the last chapter), interferes with peoples' ability to see the need for a new system. Reification interferes with peoples' ability to name the sources of their harm, and this is most egregiously overlooked by Linklater when it comes to the harms of the capitalist system itself (again, not just the results of the worst examples of greed and profiteering). Other forms of systemic harm are more easily visible. It is much easier to see the roots of patriarchy in the male-dominated world we see all around us. It is much easier to see the sources and manifestations of white supremacy in the deeply racist world minorities confront every day. In fact, this "identity politics" function as a sort of distraction to the overdetermined role that capitalism plays in perpetuating both (Meiksins Wood 1986). Reification, the simple yet pervasive obliviousness to the fundamental dimension of the capitalist mode of production produced by the ideological superstructure of capitalism, makes capitalism functionally more pernicious than other forms of oppression and - in the case of Linklater (2011), harm.

By deploying an anti- or post-capitalist (socialist) vision, Linklater would be able to couple his argument about cosmopolitan harm conventions (the progressive normative opposite to various kinds of harm like genocide or offensive war) with an egalitarian democratic alternative which would never overlook the very real structural and human harms - nor would it overlook how capitalism mystifies its role in these harms (including the actual labeling of these things as harms, harms rooted deeply in the capitalist system itself). ${ }^{84}$ By returning to the neo-/Western Marxist origins of the Frankfurt School through

\footnotetext{
${ }^{84}$ Again, just to clarify, this is not to say that all harms are reducible to capitalism. This is not an economistic argument I'm making here. The argument is, put rather simply, that there are more harms than Linklater acknowledges, and some of the harms he does mention are so rooted in the capitalist system making capitalism itself representative of the greatest decivilizing process around negating the civilizing processes (an idea deeply indebted to Frankfurt School ally Norbert Elias) that have produced the cosmopolitan harm conventions Linklater is so keen on, and rightfully so. These harms and harm conventions are deeply rooted in the progressive elements of the capitalist system, but because of that their
} 
Adorno and Fromm, the role of capitalism again takes on a special significance, a position that-regardless of the failures of the nineteenth and twentieth century communist projects - should have never been put aside by Habermas from the outset.

\section{Radical Cosmopolitanism}

Moving on to the most radical of the cosmopolitan theorists this project confronts, this section will show how although Ingram's and Cheah's approaches to the question of global justice and cosmopolitanism (or, to use their preferred terminology, cosmopolitics) are the most comprehensive and appropriately aggressive ones that engage with the Kantian cosmopolitan tradition, they are still incomplete and contradictory in similar ways as the previous two groups.

Turning to James Ingram (2013) first, we are presented with an agonistic conception of cosmopolitan democracy as multilevel democratization; democracy as a perpetual and conflictual progression, not a final, completed goal (139-149). Ingram argues that democratization makes politics an ethical site for the critique of various exclusions and injustices. In chapter one we looked at Ingram's appreciation for cosmopolitanism and for human rights regimes as sources and sites for the practice of democracy. By drawing on these traditions, people are able to make normative claims on certain political bodies and struggle for progress towards justice, defined in ways that are most important to them. Improving and supporting these avenues of disputation and decreasing the resistance to them from various places (typically traditional representatives of authority like men,

full expression is prevented; this conclusion is the one that Linklater avoids or at least left for future project to theorize more explicitly. 
religious leaders, political and economic elites, etc.) are the practical goals of this radical cosmopolitics.

Ingram's (2013) discussion is extremely abstract when it comes to defining oppression or what should be resisted (he presumably wants to maintain a thoroughly democratic perspective by not telling people what they should want to struggle for), beyond basic human rights like the ones contained in the Universal Declaration of Human Rights and the earlier Declaration of the Rights of Man (211-226, 253-262). There is very little discussion of capitalism, though Ingram does include it broadly as a source of oppression (206-207). My critique here is not simply that capitalism is the most important injustice simply because I have arbitrarily decided to privilege that category of injustice. Patriarchy and racism are equally important, yet capitalism can accommodate gender and racial equality. Attacking patriarchy does not necessarily mean attacking capitalism. Attacking racism does not necessarily mean attacking capitalism. A gender-neutral, post-racial society could be a capitalist one (though as the Fields sisters [2013] have pointed out, historically, capitalism has been complicit in heinous racism and sexism).

Capitalism is premised on the assumption of inequality, and while it has historically benefited from patriarchal and racist practices, the norms of liberal capitalism, which assert the right of all people to possess property and sell their labor equally (or more accurately, have their labor exploited equally) allow for all other inequities to be criticized and abolished without actually altering the foundations of capitalism. This is what Marx argued was the progressive element of capitalism (beyond producing the technological conditions for post-scarcity). Marx refers to the kind of political and social equality that would abolish gender and racial oppression as political emancipation. The goal is human emancipation. 
In order for democratic universalism to function it must give emphasis to the most enduring hierarchical system that is compatible with the abolition of other hierarchies and oppressions-capitalism (Marx 1978, 26-52). Ingram focuses on political, cultural, and social exclusions and injustices, while never really giving any sustained attention to the undemocratic capitalist workplace. This is not to say that such a critique of workplace hierarchy and inequality cannot be brought into the fold of Ingram's radical cosmopolitics; it certainly can.

It is the argument here that without a sustained critique of capitalism, the democratic solidarity or minimal social cohesion that is implicit even in the agonistic approach Ingram offers will never be compatible with the capitalistic mentality (how else could someone who is speaking out against injustices convince others that they are worth listening to, without that minimal social connectivity?). Capitalism maintains an antagonism that exceeds the irreducible and desirable differences that make an agonistic approach universally necessary (Mouffe 2009). By exacerbating the conflictual nature of social life, the capitalistic mentality makes the agonistic democratic processes significantly more difficult by having to deal with the excessively competitive and self-interested subjectivities it produces. Capitalism and the capitalistic mentality identify justice with subjects' equal rights to be objectified and commodified in the production and consumption process. If Ingram is right that we "should support a democratic cosmopolitics from below, defined first and foremost by the efforts of political agents themselves to overcome obstacles to freedom and equality," what do we do with the fact that capitalism seems to have allied itself with those very same causes, and in many instances the oppressed seem to welcome their economic chains - at most rallying against extreme deprivations, the 
worst working conditions, or more vaguely, inequality. The injustices of capitalism are "normal," so let's just try to make them a bit nicer (this is the basic thrust of the phrase “capitalism with a happy face" [Glassman 2000; Forbes and Ames 2009]).

On the other hand, Cheah's argument could never be accused of ignoring the importance of global capitalism. Cheah takes more of a de- or post-colonial approach that emphasizes the importance of the nation-state as a site for liberatory global justice movements against the more structural exploitation of the peripheral (Global South) economies by the core (Global North) economies. Cheah (2006) calls attention to the deeply inhuman(e) aspects of what appears on the surface to be progress. Similar to Linklater's discussion of decivilizing processes, Cheah claims that it is only by acknowledging and confronting the inhumanity that is part and parcel of economic and political "progress" that we can first see the otherwise silent suffering that has been produced and begin to look for productive alternatives (259-266). Cheah's examples are drawn from South-east Asian workers struggling for improved working conditions, and these arguments for how effective this strategy can be with pragmatic, organized labor organization are straightforward and well-made (Cheah 2006, 230-237). Where Cheah's analysis falls short is in underappreciating the power of capitalist ideology to legitimize the inhumanity it produces through either a liberal rights based argument or liberal utilitarian arguments (e.g., capitalism is legitimate because it protects our individual rights or capitalism is legitimate because overall it produces the most good for the most people). These justifications fall short of appreciating the special inhumanity that the fundamental dimensions of capitalism, detailed in the previous chapter, produce. 
These justifications or rationalizations for capitalism travel within the capitalistic mentality, and can even be brought into the nationalistic language that Cheah favors. At the very least, Cheah provides little evidence that a claim like "Capitalism makes our country stronger" would be inconsistent with a nationalistic cosmopolitics. ${ }^{85}$ How is merely emphasizing the inhumanity that capitalism produces supposed to counteract that? It has been easy enough for social-democratic cosmopolitans to argue that addressing the worst ills of global capitalism is enough. In the recent past these reformist arguments against the worst depravities of capitalism have achieved the minimal successes of marginally improved working conditions and wages, but the narrative became: Such and such a company is a bad company individually, not that the system is the problem (we saw a lot of this in the aftermath of the 2007-2008 financial collapse and Great Recession with regard to Wall-Street executives, [Harvey 2011]). ${ }^{86}$

Cheah can maintain his critiques of Adorno, Horkheimer, and Habermas in favor of his post-colonial Derridean nationalistic cosmopolitics, but he still needs to better account for the capacity for the psychological conditioning that the subjects of capitalism endure throughout their lives has the tendency to reproduce capitalism by normalizing it, dehistoricizing it, and in the end naturalizing it. Absent a critique of the psychology of

\footnotetext{
${ }^{85}$ These arguments are found throughout much of the mainstream sustainable development literature, in the work of Held and McGrew (2007) on globalization, and Schumpeter (1919) refers to this kind of argument as well in his work on state capitalism and imperialism.

${ }^{86}$ One of the most well-known examples of this pattern is the controversy over Nike's labor practices and standards (or lack thereof) beginning in 1991 (Nisen 2013). Nike experienced a great deal of backlash for paying workers in Indonesia 14 cents an hour, and this led to sustained resistance and boycotts in the Global North (the primary consumers of Nike products). Nike improved conditions and pay, but also went on a massive public relations campaign to regain its legitimacy in the eyes of the public (though the exact figures on PR spending are proprietary, Nike spends enormous amounts of money on advertising - upwards of $\$ 1$ billion in 1998) (Beder 2002). Lives were improved marginally, but there was no systemic change to speak of.
} 
capitalism, we could easily be left with a slightly more humane capitalism that is more generous towards Global South countries while maintaining the internal exploitations that is central to the capitalist mode of production (Cheah 2006, 230-268).

Let's us turn to the recent development in Greece as an example of this. Though Greece is not a Third World or Global South country, in 2015 when the Leftist SYRIZA government in Greece attempted to resist the expansion of austerity and international distributive injustice (to use Beitz's [1999] phrase), the less radical social-democratic head of that party, Alex Tsipras, caved under the pressure of the European Union elites. Tsipras's government had received a nearly $60 \%$ vote of confidence in a popular referendum to reject the EU's "bailout" offer. Tsipras, under increased pressure from the capitalistic forces of the EU, gave in to an arguably worse deal the very next day (Tsipras 2015). Global capitalism, even when channeled through supposedly more just transnational political institutions like the EU, consistently undermines democracy-but even when democracy functions as well as it can under capitalism, there is a tendency for the people to take action that maintains the capitalist system. This is the function of hegemony (in the Gramscian sense discussed in the previous chapter) and ideology internalized, normalized, and naturalized through the capitalistic mentality. We see this in Greece today, while the people want more, they acquiesce to minimal reforms within the global capitalist framework because either this is the best they can hope for, or they actually believe in the viability of the system with minor consequential changes.

\section{Conclusion}


If Adorno (2005) is right that "wrong life cannot be lived rightly" the goal must be to figure out how to construct right life from the wreckage of this wrong life. Yes, we'd still be living wrong-lives until the social relations are comprehensively changed, but that must be the goal, and it is just that, a goal. There are no guarantees. There is not even a guarantee of possibility. There is hope and the radical project of salvaging human civilization before it is truly too late (for whatever reason, whether it's nuclear war, another conventional world war, the complete collapse of the global economy, or a climate change induced global blight). I strongly believe that it is only through a reconciliation of cosmopolitanism with Marxist through the concept of the capitalistic mentality that that can happen successfully. We must reject and denormalize the mentality, that is the kinds of thinking and behaving, that makes these apocalypses not only possible, but more likely.

For the time being, I want to pre-figure the alternative that is needed to reconcile the contradiction within cosmopolitanism with respect to its strange capitalist bedfellow. We need a new mentality, a post-capitalist orientation that assaults the structural and human processes and norms that maintain the pathology of this way of thinking and behaving toward one another and our shared world. Cosmopolitanism requires a vision that conforms to its lauded, desperately important principles. This is not an anti-cosmopolitan project. It is a deeply cosmopolitan project; it is an alter-cosmopolitanism project. It is a cosmopolitan project that says, let's get cosmopolitanism right—and in order to do that we need a cosmopolitanism that draws from all of the insights of each of these cosmopolitan thinkers from Beitz and Pogge though Habermas and Linklater, to Ingram and Cheah, but looks at the social conditions of humanity realistically. This project says, we need to be different in order to have a different world. It is not enough to say as Beck (2006) and 
Beardsworth (2011) do, that we need a cosmopolitan realism that looks at what is minimally possible and probable to succeed now. This vision is far too conservative for the kind of cosmopolitan vision the world requires if it is to survive and survive well - their conception of realism is idealism. It is not enough to suggest bottom-up cosmopolitanism. That is necessary; Ingram and others are not wrong. It is incomplete though. Not all bottomup approaches are equally normatively valuable insofar as they can instantiate a democratic egalitarian postcapitalist cosmopolitanism. Just because a movement is local doesn't mean it cannot be oppressive in its own way. It might be democratic, but getting popular support for cutting taxes on the rich while cutting necessary social welfare for the poor or popular support for the stoning execution of a rape victim for the "crime" of "adultery" hardly seems like a democracy worth fighting for. But the people who advocate for or embody these views themselves did not choose them. They were conditioned into them, and until an alternative, freer, more humane conditioning replaces the exploitative, oppressive ones so dominant in the world today, a truly radical cosmopolitan democracy will remain out of reach.

A truly radical cosmopolitanism must be anti-imperialist, anti-sexist (antiheteropatriarchal), and it must be anti-capitalist. It is not enough to call for democratization across all levels of politics. It is not enough to call for the end of exploitative Global NorthSouth relations, and it is not enough to call for a global redistribution of wealth. Cosmopolitanism requires a global resurgence of compassion, empathy, solidarity, cooperation, and love. When the fundamental relationships between human beings (sexual, creative, familial, and political) are pervasively commodified, our entire world is reproduced as a commodity. When the world is up for sale, justice is up for sale. When 
justice is up for sale it ceases to be justice. Idealizing the possibility of global justice within the confines of commodity capitalism and its capitalistic mentality is a cancer within the cosmopolitan tradition. This is not a statement of probability, it is a statement of necessity. If we value global justice - that is, if we broadly believe in the fundamental tenets of cosmopolitanism that all people are of equal moral worth regardless of where they are born on this planet, regardless of their gender or sexual identity, regardless of their race or creed - we must oppose the essentials of the system that perpetuates a global (dis)order that takes the opposite positions, or even the non-position of "letting the market decide." We must oppose capitalism.

However, we must not oppose capitalism so viscerally that we lose sight of the necessary alternative. As Marx often reminded his readers, capitalism is indeed the best system humanity has tried (Eagleton 2011 59-61). It is a necessary step in the history of human civilization. We don't want to abolish capitalism only to have it replaced with one of its more grossly inhuman predecessor systems. The world ahead must not be one that moves us backwards. It must truly be a world ahead of capitalism. It must be post-capitalist, and indeed socialist. This is precisely where the next chapter takes us. Not only by looking at various theories and approaches to postcapitalism, but moving beyond the negative, critical diagnosis offered by Adorno and Fromm, and looking into their works for a potential path towards an alternative, post-capitalistic mentality suitable to a practicable, realistic, radical cosmopolitanism for the twenty-first century.

In addition to analyzing the post-capitalist dialectic of reform and revolution within the Marxist and post-Marxist traditions, this final substantive chapter will address the latent question this current chapter leaves unaddressed: if capitalism (re)produces the capitalistic 
mentality, how can a post-capitalistic mentality I've suggested is necessary to achieve a radicalized interpretation of the goals of cosmopolitanism, emerge from within capitalism? The answer lies in the same place Marx found the answer to the question he was confronted with regarding where the seeds of socialism and communism could be located. The answer is in the dialectical contradictions of capitalism itself. Fromm and Adorno again will be brought in to give us a more specific analysis of that dialectical movement, as well as how their work taken together speaks to the role that the critical and radical versions of cosmopolitanism can play in that process. 


\section{CHAPTER 4 \\ Cosmopolitanism and Socialist Strategy: Class Struggle, Radical Reform, and Postcapitalism}

"In its own class dictatorship, the dictatorship of the bourgeoisie, has no interest-on the contrary - in being called by its real name and understood in terms of its real historical power. To suppress the dictatorship of the proletariat is at the same time to suppress the dictatorship of the bourgeoisie...in words. Nothing could serve it better, in practice"

(Balibar 1977, 156).

"There is no need to fear a pessimism that remains committed to emancipation.

Pessimism is not cynicism. Pessimists may, as Salvage does, simply insist that comrades in that endeavor realise - and act upon the realisation of - just how hard this is going to be. Having a pessimistic analysis certainly doesn't mean good things never happen"

(Warren 2015, 105).

"Is it worse to hope or despair? To that question there can only be one answer: yes. It is worse to hope or to despair.... We must learn to hope with teeth" (Miéville 2015a, 187-

\section{Introduction}

188).

Cosmopolitanism, born out of global capitalism, is normatively and logically inconsistent with capitalism. Global capitalism cannot be globally democratized. The capitalistic mentality undermines the production of the consciousness that would allow for such a broad reformation to take place. Though the argument here takes place principally in the realm of theory, the continued expansion of neoliberal capitalism, the continued failures of Leftist movements, and the popularity of Right-wing neoliberal demagogues like Donald Trump to centerist neoliberals like Barack Obama, David Cameron, and Angela Merkel. No matter how popular these figures may be or how different they may be from one another, they all represent the strength of the capitalistic mentality to undermine genuine reform, because that reform will never be properly aimed at the true enemy of progress under late capitalism: capitalism itself. Where does this leave us? What follows in this chapter, an argument which is continued in the concluding chapter that follows, is meant as one possible - and admittedly and intentionally speculative-normative 
resolution to the contradictions between cosmopolitanism and the contradictions it harbors with its implicit and explicit relationship with capitalism detailed in the previous chapters. The core aspects of this reconciliation involve renewed approaches to democratization (against capitalistic versions) as well as a negative dialectical conception of class struggle in the context of an argument for radical reformism with a democratically-rooted conception of leadership within and beyond existing political processes, structures, and institutions.

The argument presented in this chapter looks to the tradition that has been largely eschewed by contemporary cosmopolitans, contemporary Marxism, for solutions. However, the argument here is not that we should replace cosmopolitanism with Marxism (or the reverse), but instead that by putting these traditions into conversation, we can see that they have much more in common than they do differences between them, especially once cosmopolitanism is realized itself to be contradicted by its relationship to capitalism, as we saw in the previous chapter. After touring the most relevant and recent developments in contemporary Marxism, highlighting their cosmopolitan dimensions, this chapter will show that both a properly radicalized cosmopolitanism represents a negative dialectical conception of reform and revolution embodied in Erich Fromm's conceptualization of radical reform - a reformism that goes to the roots of the roadblocks to true emancipatory progress without devolving into an impossible theory of fast revolution; in our current situation that means pursuing policies and engaging in movements that name the enemy and seek to defeat it, with radically realistic approaches.

The psychology of capitalism, the capitalistic mentality, ensures that revolution or insurrection could never defeat capitalism while capitalism is still thriving, but it also 
ensures that reformism will always be inadequate-leaving open the door to the necessity of radical reform, creatively imagined and realistically pursued can produce a world ahead of capitalism - a postcapitalist world that could be consistent with a cosmopolitan sense of justice. Cosmopolitanism needs to be able to answer the question: what if capitalism cannot be reformed? (even if one is not convinced by the argument up to this point, what if it is true?). Left theory needs to be able to answer the question: what do we do if revolution is no longer possible? And they both need to be able to answer the question: what if revolution is also our only hope in a world on the verge of drastic ecological catastrophe and pervasive injustice? The answer this chapter suggests to all of these questions is-embodied in notions of class struggle (within and beyond class), unlimited democracy, and radical reform — everything we possibly can and that still might not be enough. ${ }^{87}$

This chapter begins not just where the last one ended, but also where left theorist Gilbert Achcar (2013) ends his argument for the useful combination of cosmopolitanism and Marxism. Since at least 1992 and Chris Brown's early foundational text of contemporary international political theory, Marxism as a version of international socialism has been interpreted as a cosmopolitan perspective. Marx argues that over time, through the historical development and geographic expansion of capitalism, capital takes on a "cosmopolitan character" (Marx 1978). What Marx never explicitly says is that as capital takes on a cosmopolitan character the working class also takes on a cosmopolitan character. With that said, and as Timothy Brennan (2003) and Peter Gowan (2003) and David Harvey (2009) have argued, Marxism is an internationalist perspective. Brennan

\footnotetext{
${ }^{87}$ There are very recent articulations of this kind of radically hopeful pessimism in the still very young pages of Salvage, the British journal of revolutionary arts and letters, which is currently on its third issue, as well as in the pages of Terry Eagleton's Hope Without Optimism (2015).
} 
argues, as many of these other Left critics of cosmopolitanism have, that cosmopolitanism is merely the ideology of globalization. It is an ideology of globalization, but its normative components, finding their origins in Kant and having been most fully developed by Marx, before contemporary cosmopolitans have gone back to Diogenes and/or deemphasized the Marxian-cosmopolitan legacy.

It is not just the Left critics of cosmopolitanism who offer a version of the two traditions that is divergent. As mentioned in the Introduction, Richard Beardsworth (2011) offers a discussion of cosmopolitanism that, though he is very clear throughout that he is talking about liberal cosmopolitanism, draws strict lines of distinction between cosmopolitanism and Marxism, before offering his own conception of cosmopolitan realism based on differential universalism and moral responsibility in leadership. None of the contemporary "Marxist" theories that will be addressed in this chapter are dealt with by Beardsworth, and in his book he offers a clear and cogent explanation for why he presents the thinkers he chose as such-namely that they retain more of the classical Marxist positions on the labor theory of value, the rejection of the separation of the political and economic spheres, as well as their rejection of non-class-based approaches to individual agency and change (111-140). In fairness to him, his project was focusing on the most traditional instantiations of the Marxist tradition within International Relations as an important and informative foil to his sophisticated and complex brand of (liberal/socialdemocratic) cosmopolitan realism, rooted in many of the thinkers detailed in chapter one of this project (David Held is probably the most crucial and consistent inspiration for Beardsworth's cosmopolitanism). As Beardsworth says, it is not that Marxists are wrong per se, but rather that they over-simplify many of their key claims regarding the 
impossibility or impracticality of pursuing a more globalist or internationalist approach to their opposition to capitalism. What I want to do here is go back to Chris Brown's earlier (1992) insights on cosmopolitanism that includes Marxism as a version of cosmopolitanism. He says:

[T] he proletariat is a universal class even though not all human beings are members of it. Unlike previous victors in the class war, the proletariat, when it conquers, will establish a society without classes and therefore without class oppression....The dictatorship of the proletariat will be a phase preceding the withering away of the state and therefore of the divisions between human beings....[T]he cosmopolitan intentions of Marxian socialism are clear. (45)

The neo-/post-Marxist theorists addressed in this chapter offer a version of "Marxism" or postcapitalism that do not fit into Beardsworth's presentation of the Marxist tradition represented by the likes Brenner, Gowan, and Gamble, who focus on more immediate nation-state oriented resistances to capitalist globalization. It is by focusing on the less rigidly dogmatic representatives of the contemporary Marxist tradition that a more productive interaction between cosmopolitanism and its Leftist critics becomes feasiblespecifically in regard to the specific contradictions detailed in chapter three.

What is maintained most consistently here from Beardsworth's presentation of the cosmopolitan response to Marxism, as he describes it, is the emphasis on the enduring importance of universalistic ethics in contradistinction to even the neo-/post-Marxists addressed in this chapter, who to a large degree, at least superficially, eschew the language of universalism and normativity altogether (though this certainly does not apply to Fromm and only somewhat to Srnicek and Williams' accelerationism)(137-138). Lawrence Wilde and Michael J. Thompson among others-building on the work of Critical Theorists like Fromm - have presented, over the past three-plus decades, convincing reasons to think of 
Marxism and the critique of capitalism more broadly in both structural and ethical terms, something which Beardsworth rightly points out is typically taboo among Marxists (Thompson et. al. 2015). I will go on to attempt to show here that the necessity to think of cosmopolitanism on more contemporary neo-/post-Marxist terrain can express the strategic-political import of rebuilding a more robust ethical critique of capitalism, particularly in the context of global justice. Put more directly, and this is something that James Ingram argues in his Radical Cosmopolitics, politics without ethics and ethics without politics leave us with impoverished versions of both. In the context of the radical reformulation of cosmopolitanism presented at the end of this chapter, the ethical dimensions of the critique of capitalism and the normative importance of thinking postcapitalism ethically have the potential to circumvent the apathetic (a)political commodified, consumeristic elements of the capitalistic mentality and can motivate the negative dialectical conception of class struggle as a process of learning and reconditioning necessary to achieve what Rosa Luxemburg calls "unlimited democracy," which means nothing more than the normative goal of democratizing all aspects of human collective life. According to Luxemburg, unlimited democracy best captures the true spirit of the dictatorship of the proletariat. ${ }^{88}$

\footnotetext{
${ }^{88}$ Despite the very real historical failures of the ostensible attempts to achieve the dictatorship of the proletariat supposedly represented by the USSR, Cuba, and other so-called "communist" countries, the best historical example of the dictatorship of the proletariat is actually the Paris Commune in late nineteenthcentury France. Engels explicitly states that Marx's depiction of the goals and practices of the Communards in the Commune in his essay "On the Civil War in France" represented exactly what they meant by the concept of the dictatorship of the proletariat. Any close historical analysis of the Commune betrays the perhaps uncomfortable truth for critics of Marxian communism (as well as for the supporters of Lenin, Stalin, Mao, Castro, and other self-proclaimed Marxist leaders) that the principles and practices of the Commune (including democratically-elected and recallable representatives, egalitarian socioeconomic practices, and deliberative decision-making) stand in stark contrast to basically every other so-called attempt to realize the dictatorship of the proletariat in practice (Marx-Engels Reader, 1976; Ross 2015; Harvey 2016; Lissagaray 2012; Gluckstein 2011). A deeper conceptual analysis of the concept of the dictatorship of the proletariat in the work of Marx and Engels' writings was produced by Hal Draper in 1962 in New Politics and later became a monograph on the concept through Marx and Engels up-through
} 
Achcar (2013) wants to call for a merger of these traditions. For him, cosmopolitanism is a future-oriented ideology, and so is Marxism (151-155). Both are indeed oriented towards existing material conditions, but both also have a vision for the future. One is impoverished by its relationship with capitalism (cosmopolitanism), and one is impoverished by pretenses of purity and a cruel combination of optimism about the immediate viability of the alternatives to capitalism and a perverse fatalism about all progressive avenues (ibid).

What this chapter will do is suggest that the truly realistic path forward for the global community is a radical reformulation of the cosmopolitan project that embraces the insights of some of the most prominent and compelling theories that contemporary Marxism has to offer, including the work of Laclau and Mouffe, Hardt and Negri, J.K. Gibson-Graham, Erik Olin Wright, Etienne Balibar, and the most recent developments under the much-disputed label of "accelerationism." The goal will be to show that by emphasizing the transnational and indeed cosmopolitan character of capitalism, the capitalistic mentality, and the immense power of global capitalism against the forces of democracy and egalitarian justice, that a singular approach, response, and/or strategy is no longer feasible, if it ever was.

The final section of this chapter — through a renewed reading of Balibar's earlier work especially, in combination with the most recent developments in Marxist theorizing, alongside Fromm's argument for radical reform, the emancipatory thrust of Adorno's

Lenin's interpretation and deviation. It is Draper's explanation (though largely consistent with Kautsky's more famous explication referenced in the main body of this chapter) of the dictatorship of the proletariat as Marx's intentionally ironic reversal of the then dominant view that one class - the aristocracy or bourgeoisie - should rule over the peasants and working classes, which inspires my application of the concept as mass democratization in the cosmopolitan tradition. 
negative dialectics, and contemporary cosmopolitanism —aims to produce what we might call a neo-Marxist cosmopolitanism or a neo-cosmopolitan Marxism for the twenty-first century, which names the enemy of progress (capitalism) while avoiding the dogmatic refusal to engage with contemporary theories of cosmopolitanism and the radical potential of engaging with existing transnational political institutions.

We can find inspiration in many sources for this frustration-inspired multiplicity of approaches approach, but the specific engagement with liberal-bourgeois theory, which nearly all of contemporary cosmopolitanism exemplifies can be found in Marx himself. We should remember that Marxism emerged out of the failure of the once revolutionary demands of the liberal bourgeoisie against the feudal system. For Marx, Enlightenment liberalism ceased to live up to its radical potential and thus needed to be reformulated against itself in the new context of the industrial nineteenth century. Cosmopolitanism, while admittedly never a revolutionary theory nor ever representing a revolutionary class interest, is best understood as an outgrowth of the very same failed liberal tradition that Marx originally castigated (Sayers 2015). Cosmopolitanism is both made possible and impossible by its complicity with capitalism, just as was the case with nation-state-centric liberalism of the eighteenth and nineteenth centuries.

A radical approach to progress must take cosmopolitanism to task for its complicity and on-going failures, while not abandoning its core message: the demand for a globallyjust world beyond the confines of a morally-arbitrary nation-state system. This is can only be made possible, and maybe that possibility cannot even be guaranteed, by bringing cosmopolitanism, including both its normative vision and its actual political 
manifestations, into constructive conversation with the most recent developments in postMarxism, broadly understood.

Refusing to engage productively with cosmopolitanism surrenders the remaining potential of unlimited democracy in the twenty-first century to the forces of pessimistic intra-Left dogmatism and the optimistic attention given to discourses, identity, and nonhierarchy (as we will see later here with the post-Marxists) under the deeply alienating, distorting conditions of capitalism, instead of combining that critical pessimism with the radical hope that Marx himself embraced. We cannot completely replace the existing order of things, unless we first take hold of that order as it currently stands, to make it how it always needed to be — at least ethically speaking (Thompson et. al. 2015).

This is a project that articulates the likelihood of its own failure, but also one that seeks to minimize that likelihood by dialectically demystifying the psycho-social forces that could undermine it. The people of the world are both ready and almost completely unprepared for what needs to come. The goal is to prepare one another by working together within and against both the nation-state and the transnational state (Robinson 2004). Because of the long-term socio-cultural conditioning of the capitalistic mentality, revolution is impossible now (perhaps it always was), but it is also our only hope-so long as that concept of revolution is conceptualized along negative dialectical terms. ${ }^{89}$ Radical progress demands radical solidarity, itself a mere momentary potential under capitalism. Radical realism in service of radical progress thus demands that we must begin to sharpen

\footnotetext{
${ }^{89}$ Jameson (1996) contends that Marx's concept of revolution was always a long-term project. While I see contradictory or at least inconsistent comments in Marx's (and Engels') work, I come to a similar conclusion that Jameson reads in Marx. The idea of the fast revolution that takes place in only a few months or year is inconsistent with the degree of change that a revolution entails. Revolutions, if we can call them that when they extend over a much longer period of time, likely take generations.
} 
not just our bayonets, but also our wits, together. This means not abandoning a single opportunity to make peoples' lives better now, all while building alternatives for a world ahead of our own, while also acknowledging that every step that is not aimed at defeating and replacing capitalism might very well be one step closer to the grave that capitalism seems to have tricked its gravediggers into building for themselves.

\section{Back to the Future: Towards a Dialectical-Cosmopolitan Reading of Neo-/Post- Marxism}

In a world with a vast array of oppressions and subjectivities (sex, gender, orientation, race, ethnicity, religion, class, etc. etc.) does privileging class still make sense? Laclau and Mouffe say no. Hardt and Negri say, well yes, but no—-we need a new analytical framework for the twenty-first century (their suggestion is Empire and Multitude resulting not in communism but common-ism (or Commonwealth). J.K. Gibson-Graham say somewhat, but only in connection with gender and a discursive critique of capitalism and its basis in non-capitalism. The accelerationists, especially Nick Srnicek and Alex Williams, believe that the contradictions of capitalism need to be accelerated in such a way that class relations become irrelevant to a postcapitalist world where work is done voluntarily and is no longer tied to compelled labor (accomplished through automation). Erik Olin Wright suggests that class does still matter (as do many others, including the late Ellen Meiksins-Wood [2016]). Etienne Balibar's work, while taking up positions very similar to Laclau and Mouffe in recognizing the diversity of subject positions in relation to various oppressions beyond class still maintains a strong economic critique, will be engaged with through his dialectical "re-interpretations" (though whether these are genuine 
reinterpretations or an attempt to regain an earlier meaning is a matter of debate) of two central Marxian concepts: class/class struggle and the dictatorship of the proletariat. Though these dialectical interpretations are maintained in his recent work, that work has shifted to more mainstream discussions of cosmopolitanism and liberalism (albeit from a very critical perspective) with an increased emphasis and focus on the role of citizenship as a radical juridical subject position that has historically served as a launching point for revolutionary action.

What all of these theorists have in common besides speaking to the question of whether class is still relevant in the late twentieth and early twenty-first centuries is that they also include, with varying degrees of specificity, theories about how to move beyond capitalism towards democracy. We start again where we ended the last chapter: true progress demands that we move beyond capitalism towards a humane postcapitalism, the label for which I, as these thinkers do, give "socialism." What also makes this selection of neo- and post-Marxist theories important for the argument of this chapter and the overall project is that they all represent a rejection (to varying degrees and take varied directions) of the traditional understanding of the nation-state, in response the speeding up of capitalist globalization over the past several decades - a central dimension of cosmopolitanism. All of these theories are somewhat cosmopolitan in that regard, but they all also offer a perspective that affirms some of what Fromm means by "radical reform" under the pressure of the pathological marketing social character and the having mode of existence, as well as Adorno's critique of the erosion of subjectivity produced through the dominance of instrumental reified identitarian thinking under the conditions of capitalism (the latter of which are detailed in chapter two). 
These theorists each offer an opening for the theoretical convergence of Marxism and cosmopolitanism, at least in a broad sense (they certainly do not completely overlap and what follows should certainly not be read to imply such). While largely avoiding the language of cosmopolitanism for the most part, all of these theorists, with perhaps the exception of Laclau and Mouffe, articulate a postcapitalist political theory that is transnational or at least not explicitly limited to domestic concerns. Furthermore, they all project the idea that genuine democracy at any level is only possible by a radical break with the political and social conditions of capitalism and that this break demands transnational struggles, even if those struggles emerge at the local or national level.

The conclusion that I pull from the discussion that follows, beyond what was just stated, is not that we need to bring class back into our analyses as social scientists and theorists, but rather a focus on capitalism more broadly, that while it should still be understood as a fundamentally class-structured system, its class-element should not be assumed to have clearly radical subjective, psychological, or behavioral manifestationsespecially when it comes to moving beyond capitalism..$^{90}$ The primary theoretical role of this chapter is to engage with the concept of class, and through these various discussions address the question of how to maintain —and the importance of maintaining — a critique of capitalism, if class can no longer be privileged a priori as a site of revolutionary action, a point made in various ways by these authors, but in a way that still does not grabble with the cross-class consequences of the capitalistic mentality.

\footnotetext{
${ }^{90}$ To make things a bit more explicit here, building off of the previous two chapters, I am aiming to develop, or at least open the door to theorizing, a negative-dialectical understanding of capitalism as a class-system (that is, there are those who own the means of production and those who do not), but that that class-structure is not determinative of historical change (at least not under the ideological, psycho-social conditions of late capitalism).
} 
Before delving into this complex literature, let's remind ourselves of the list of generalized characteristics of cosmopolitanism with which I ended chapter one:

1. Our basic worth as human beings, extending to a desert for basic political, social, and economic rights or--at least the content goals of those rights-is not ethically restricted or shaped by regional, nation-state, or even more local boundaries. In other words, cosmopolitanism requires that all people be protected by a set of context-sensitive basic human rights.

a. The corollary to these rights is that there is an obligation to not violate them in addition to working towards their achievement, both structurally and in specific instances of known violations.

2. The determination of those basic human rights as well as any additional laws or policy at any level of governance should include all those people who are likely to be affected (or who are in practice affected) in a coercion-free discourse

a. The corollary to these rights is that there is an obligation to aim to secure the socioeconomic conditions necessary for adequate participation by all those who should be included. This includes a duty to accept outsiders, even if only temporarily, if their current existential situation is in violation of the first or second principles (i.e., a right to hospitality).

3. Democratization and human rights include institutionalization but they are also embodied in the everyday struggles by those who are worst off. Democratization is the core of cosmopolitan universalism and is an always incomplete process that is undermined by exploitative socioeconomic systems and practices which cause undue harm (including structural racism, sexism, exploitative labor, and lack of socioeconomic opportunity). 
In 1985, Ernesto Laclau and Chantal Mouffe published one of the-if not themost significant contributions to contemporary post-Marxism in their co-authored book Hegemony and Socialist Strategy. ${ }^{91}$ As mentioned above, the principal contribution of this text is the use of Gramsci's concept of hegemony to shift Marxism away from traditional concerns of class identity to put class identity alongside other identities like race, ethnicity, gender, religion, nationality, etc. Laclau and Mouffe make the claim that in the late twentieth-century it is no longer feasible to privilege class in regard to building a radically democratic movement aimed towards a radically democratic society, but instead particular “cultural factors" needed to be re-emphasized (Keucheyan [2010] 2013, 238-242).

Their argument for building a new hegemony (a dominant alliance of divergent groups with shared interests or at least a shared opponent) is based on the belief that the classical proletariat is in itself diverse, and that diversity would prevent solidarity unless other cultural dimensions were recognized, accounted for, and given pride of place. It is not only that the proletariat or working class is no longer a privileged historical subject, but rather that the working class itself no longer exists as a coherent social identity. This is when Laclau and Mouffe borrow most explicitly from E. P. Thompson's (1966)

\footnotetext{
${ }^{91}$ Goran Therborn (2008) argues that the primary distinction between post-Marxism and neo-Marxism is not necessarily related to the use of poststructuralism, but instead has to do with how closely one follows from Marx. He goes so far as to say that first-generation Critical Theory is likely the first example of postMarxism (165-166). While I think Therborn's point is fair, especially when one looks at the critique of class offered by Adorno ([1997] 2003, 93-110) and Fromm's refusal to engage in a substantially classoriented approach throughout his career, the inclusion of the term Marxism expresses an engagement with the concepts of Marxism in a most positive way, while representing an important deviation. To keep thing simpler, I will be using the label post-Marxism exclusively for thinkers who bring post-structuralism into conversation with Marxism and neo-Marxism for thinkers who do not, but instead seek to update or reapply Marxist concepts in a new era. Though with regard to Etienne Balibar, given his complex and critical relationship to (post-)structuralism, I agree with Therborn that he is a unique figure in that he fits in both categories, unless of course one takes Peter Dews' (1987) argument that Adorno prefigures many of the claims made by post-structuralists in his work on Marxism and negative dialectics more broadly, Adorno would also fit this dual position as well.
} 
conceptualization of class as experience of class (that is, there is no objectively existing class without class consciousness, though there are certain structural conditions like capitalism that could allow us to predict where antagonisms will develop in certainly times and place, which is itself related to Lukács' original formulation that there are objectively existing classes and the development of class consciousness is an historical question, not an ontological one with regard to class) (Laclau and Mouffe 1985, 157; Keucheyan 2013, 241).

What is most interesting about this contribution by Laclau and Mouffe is that it is still supposedly a socialist and Marxist approach, but it abandons any focus on the core antagonist of socialism and Marxism: capitalism. Capitalism, as the determining mode that is defined by class, can no longer take center stage because class no longer empirically takes center stage. This refusal to take capitalism on forcefully is exemplified best by Laclau and Mouffe's critique of Althusser's concept of overdetermination. For Althusser (1977; 2009), building off of Freud, society, like psychopathology, is overdetermined but in the last instance determined by the economy (for Freud it is childhood trauma/sexuality that is determinative in the last instance). What this means is that society is shaped and historical change occurs for diverse and complex reasons that are not knowable in advance due to iron laws of history, as Marx ostensibly argued (though this is highly debatable, it is a commonly held interpretation of Marx's oeuvre). It is impossible to say that every event or most antagonisms are principally economic in nature, as was assumed by most Marxists and Marx himself in that the general trajectory of history could be analyzed and understood by giving a special emphasis to economic concerns. Laclau and Mouffe offer a complicated but in the end shallow critique of this theory, simply positing that something 
cannot be overdetermined and determined in the last instance (1985, 97-100). This move represents the least Marxist moment in Hegemony and Socialist Strategy, besides its overall emphasis on inequality as opposed to exploitation or alienation. ${ }^{92}$ The result is a replacement of the socialist project with a radical democratic one, leaving capitalism obscure among a variety of other social antagonisms. To elaborate, because social class is placed on an equal basis with other kinds of antagonisms like race and gender, the overarching role of capitalism (even beyond class, as I will argue more directly later, is crucial to addressing the capitalistic mentality — which itself is produced by a class system though functions in excess of class divisions) in shaping racism and sexism, for example, is made imprecise to the point of near-irrelevant in this early version of post-Marxism.

For Laclau and Mouffe, subjects are not primarily constituted by material circumstances, but rather by their material-discursive relations, which they argue are not a kind of idealism in the Kantian-Hegelian sense (1985, 152-154). While we can see how discourses are not themselves noumenal or ideal in the philosophical sense, they lack a coherent materiality that distinguished them from the kind of relations that Marx and Marxists have historically focused on. This is important because it speaks to how hegemonies are developed. According to this theory, building hegemonies is primarily a discursive activity: control the dominant discourse, control reality. Understood in the

\footnotetext{
${ }^{92}$ Laclau and Mouffe even go so far as to criticized Balibar, Althusser's student and collaborator on Reading Capital, for his attempts to argue that in addition to society being constituted by a variety of antagonisms which cannot be reduced in every or even most instances to economic antagonism, and that the economic base might not be the driving force of history, that it still provides a kind of structuration which shapes these other antagonisms and the movement of history more broadly-more than other antagonisms consistently do. This slight shift was still not enough for Laclau and Mouffe, because according to them, Balibar still, along with his mentor Althusser, maintained the objective a priori importance of class and class struggle (Laclau and Mouffe 1985, 100-101).
} 
language of the Marxist tradition, Laclau and Mouffe are calling for the democratization of the material-discursive relations of production (of power and identities).

While discourses are certainly important, as we will see again shortly with J.K. Gibson-Graham, they cannot be given pride of place in a world that is materially conditioned principally by capitalism. And because antagonisms are fundamental to social reality, revolution becomes not only untenable, it becomes undesirable if the result is an attempt at an antagonism-free society (which is only further complicated by Mouffe's favoring of an agonistic society, because if an antagonism-free society is not possible but an agonistic one is, why couldn't revolution produce agonistic socialism or agonistic communism or whatever label one prefers?) (Mouffe 2000). Regardless of that contradiction across Mouffe's oeuvre, Laclau and Mouffe are functionally institutionalists. They see change coming through the counter-hegemonic destabilization (or radical opening) of the economic and political power structures of society, which can only happen through discursive and both conventional and non-conventional political struggle, excluding anything that aims to eradicate difference — the ontological substance of human collective existence, according to this approach $(1985,188-193) .{ }^{93}$

In works of significant originality that build on Laclau and Mouffe to some degree, Michael Hardt and Antonio Negri offered post-Marxism its most radical (re)formulation from 2000 with the publication of the (in)famous Empire, hailed as the Communist Manifesto of the new century. The most fundamental contribution of the Empire trilogy is to offer a novel ruptural theory the replaces the "old" Marxian binary of the bourgeoisie

\footnotetext{
${ }^{93}$ Mouffe has gone on to clarify precisely what she meant by political struggle in later work, drawing on the work of Nazi political and legal theorist Carl Schmitt and his concept of the political as meaning conflict where there is a friend/enemy distinction (Mouffe 2000; 2011).
} 
and the proletariat in a way that retains the radical potential of the oppressed without reproducing any kind of untenable classist reductionism, whether because the original binary was always wrought with reductionism, or simply because we no longer exist in the nineteenth century (Hardt and Negri seem to imply a mixture of the two, though the latter is fundamentally more important).

To summarize, for Hardt and Negri $(2000 ; 2004)$ Empire replaces both the traditional Marxist concepts of the ruling class and imperialism with a deterritorialized notion of imperial sovereignty that is both everywhere and yet in no specific place (though certainly having particular manifestations) (2000, 3-23). Empire also represents the dissolution of traditional state sovereignty as a result of the progress of global capitalism that demands the free flow of goods and labor under novel conditions of cognitive laboring (knowledge based labor as opposed to manual skill based labor). The logic of the automated factory becomes the logic of the global system. From within the networks of Empire emerges a new oppressed "class" of people, the Multitude. The Multitude replaces or rather includes a twentieth and twenty-first century proletariat (the "cognitariat") as well as the various other oppressed subjectivities like femaleness, black/brownness, nonheteronormative sexual identities and orientations, etc. (Hardt and Negri 2000; 2004; Keucheyan 2013, 85-94).

Because Empire does the work of upending the traditional notion of state sovereignty, the Multitude need not seize the institutions of the state, which Hardt and Negri (2000) more or less view as being vestiges of pre-Empire capitalism that continue to service and are indeed constitutive collectively of Empire, the Multitude will form cooperative resistance movements that undermine both the last vestiges of the nation-state 
and Empire through the formation of commonwealth (commonwealth being Hardt and Negri's catch-all term for postcapitalism)(Hardt and Negri 2011). The solidaristic social movements of the Multitude replace class struggle while also taking into account the social antagonism theory of Laclau and Mouffe. The Multitude is constituted through these antagonisms and the demands of Empire. The Multitude through their own deterritorialized subjectivity and the creative sharing that the increasing knowledge-based labor that characterizes this postmodern, cognitive capitalism, must aim for a resurrection of the ideas of "the common." The common is distinguished from the private and the public. The private is the ownership of wealth and the means of production by private individuals and corporations. The public is government or representative government ownership of wealth and the means of production. The common is controlled and constituted by the Multitude, by (though Hardt and Negri don't like this term) “the people” (Hardt and Negri 2012, 101 108).

The political mechanisms for getting to this point are somewhat unclear in the work of Hardt and Negri. Most interlocutors, like Mouffe (2013) and Harvey (2013), suggest that Hardt and Negri reject all institutional mechanisms for progress. While there are clear critiques and indeed outright rejections of existing state institutions and parliamentary politics in their work, there are also more pragmatic statements that speak to the possibility that if this kind of power were attained by the Multitude the entire state system and conventional representative politics could be reappropriated like the traditional idea of the dictatorship of the proletariat as I will advocate later in the form of unlimited democracy, reformulated and rearticulated so that representation becomes something like a radically democratic communism (Hardt and Negri 2012). 
What is missing from Hardt and Negri's approach ${ }^{94}$ is precisely how it is that the Multitude get beyond the biopolitical structuring of Empire and global capitalism more specifically. The Multitude is created through Empire for the advantage of Empire, but beyond asserting that the characteristics of the Multitude would produce the mechanism of overthrowing Empire, which are actually very similar to Marx's initial theorization of how the proletariat would eventually come to resist and overthrow capital, there is no explanation given or appreciation for just how crucial the logic of capitalism (or in this case Empire) is in conditioning this new global proletariat. Put in their words, how does the legitimating ideological and biopolitical power of Empire simply end up ineffectual in maintaining the acquiescence of the Multitude? The Multitude simply have an "aha!" moment where they realize the commodification of creativity and the common sources of knowledge that form the basis of their social labor could be better utilized without the demands of Imperial profit-making?

In my language, does the capitalistic mentality, that psycho-social pressure that produces the initial conditions of conformity to capitalism, simply disappear? For Hardt and Negri, it seems as though the Multitude always-already did not "buy into" the logic of capital, or that they were ignorant to the power of collective action and cooperation before

\footnotetext{
${ }^{94}$ There have been many other critiques of the theory of Empire and Multitude, many detailed in Debating Empire (2003) that are left unaddressed here. It is however worth noting that I do not accept Hardt and Negri's full thesis that Empire involves the complete loss of national-state sovereignty. I see no reason why the various mostly classical Marxist critiques offered in that collected volume--which basically argue that the state still has a major role in the perpetuation of capitalism as well as there being internal conflicts within Empire, something Hardt and Negri initially reject — could not be made compatible with the broader significance of Hardt and Negri's contribution. Why can it not be that there is this thing (Empire) emerging alongside nation-states, which retain some progressively degrading and threatened sovereignty, and that there is new metasubjectivity emerging within this developing Empire that represents a new potentially revolutionary historical subject? Put more simply, perhaps Hardt and Negri got a bit too far ahead of history - that we are not quite at the point yet that they thought we were, but the critics are perhaps a bit shortsighted to see that not that much has changed.
} 
Empire. As I have theorized, though, this is precisely how capitalism (and indeed Empire) reproduces itself - through the naturalization of capitalistic norms and mores. Individuals see cooperation as instrumental or contingent based on one's self-interest. They do not see cooperation and community as basic and formative psychological needs.

The biopolitical dominance of Empire appears to be merely functional; the Multitude works within Empire because that is how they make their living. For Foucault, biopower (and his earlier concept of discipline) were meant as a critique and replacement of Althusser's more comprehensive understanding of ideology. Hardt and Negri build on Foucault's critique, but they also seem to take it is as a given that with biopolitics, there is nothing that can be coherently called ideology. Even if the concept of ideology is incoherent or unsustainable empirically, I showed in chapter two that even if ideology is not the proper term, there are absolutely deeply powerful psychological conditions that emerge alongside capitalism. If biopolitical production is the production of certain subordinate subjectivities, how it is that the production of these subjectivities upends their initial source? Again, this is very similar to Marx's initial theory of the proletariat as the gravediggers for capitalism that capitalism itself creates. However, chapter two represents as much a critique of the classical understanding of ideology as it does of cosmopolitan progressivism. Ideology is all around us and through the capitalistic mentality can actually be seen to contribute to biopolitical production, but the path beyond that subjectification is unclear. Again, my approach is very sympathetic to Hardt and Negri, but there is still a great deal of manual labor that forms the basis of the global economy. ${ }^{95}$

\footnotetext{
${ }^{95}$ We can see the acknowledgement of the limitation of the consciousness arising in the Multitude in their most recent book Declaration.
} 
Only by looking negative-dialectically at the concept of biopolitical production or the capitalistic mentality itself can we visualize the radical opening that might be there. As with the capitalistic mentality's empirical manifestation, it is not meant to include everyone or every single behavior. Biopolitical production does not, nor should it, be meant to imply that everything that ever happens within Empire is a moment of structured biopolitical production. Where Hardt and Negri seem to collectivize the agency of the Multitude, it will take micro-resistances that build into macro-resistances, and it must begin with the recognition of the specific elements of our humanity that have been biopolitically produced in the service of Empire. We need to recognize the elements of the capitalistic mentality and attempt to counteract them in our behavior and in our interactions with others, normatively. Empire is immeasurably strong and indeed produces the Multitude, but what is it about the Multitude that would necessarily compel them to develop Commonwealth (or communism)?

While Hardt and Negri offer an explicitly globalized analysis of the contemporary condition and path toward emancipation through their notion of the common and commonwealth, J.K. Gibson-Graham offers a much more localized counter-position (and though they certainly do not use the language of Empire and Multitude, what they offer could be seen as a microcosm of the radical potential of the Multitude to develop Commonwealth). In many ways the feminist post-structural post-Marxist account offered by Gibson-Graham is much more based in specific local manifestations of non-capitalist or anti-capitalist practices. The argument they present in their two main works The End of Capitalism (As We Knew It) and Postcapitalist Politics are aimed at disrupting the monolithic discursive hegemony of the capitalist mode of production, which following 
many of the theses presented thus far, presents capitalism as an inherently incomplete system that is in fact constituted by non-capitalism. J.K. Gibson-Graham take a more embodied and place-based approach to subverting the hegemonic discourse of capitalism by explaining and promoting non-capitalisms that undergird capitalisms.

I will begin now with the major work of J.K. Gibson-Graham in 1996, The End of Capitalism (as We Knew it): A Feminist Critique of Political Economy, their groundbreaking work of feminist-poststructural Marxism. In it they "[problematize] 'capitalism' as an economic and social descriptor. Scrutinizing what might be seen as throwaway uses of the term - passing references, for example, to the capitalist system or to global capitalism - as well as systematic and deliberate attempts to represent capitalism as a central and organizing feature of modern social experience, the book selectively traces the discursive origins of a widespread understanding: that capitalism is the hegemonic, or even the only, present form of economy and that it will continue to be so in the proximate future" $(1996,2-3)$.

In other words, if we continue to perpetuate the idea and the discursive imaginary of capitalism as a comprehensively and absolutely dominating hegemonic totality, why would alternatives ever be attempted? It would be absolutely irrational for the average person to attempt to subvert an oppressive totality such as the imaginary that has been constructed around global capitalism. Gibson-Graham's work is a strong attempt to deconstruct the ideational chemistry of what we perceive as "global capitalism," and even at first blush the imaginative hegemonic architecture is shown for what it is and isn't: It is not a coherent, universal, monolithic totality. Capitalism is not one thing; the only totality of capitalism is perhaps the discourse around it. The discourse creates and embodies a 
mythic reality. In actuality there are multiple capitalisms and even within those multiple capitalisms are non-capitalist economic activities. Gibson-Graham even go so far as to show that the conventional and primarily monolithic version of capitalism (as we have typically understood it) would not be possible without non-capitalist economic activity. The ideational architecture of the totality of Capitalism becomes exposed as a mythic "beast"; Capitalism is actually a combination and interrelationship of capitalisms and noncapitalisms (Gibson-Graham 1996; 2006).

The discourse of the hegemonic beast is imploded in Gibson-Graham's exposition. They take aim at the discourse of capitalism, because like any mythic beast or bully, it is empowered by reputation, an almost universally artificial reputation. Destroy the reputation, decapitate the beast. At least, this is the motivating idea. Perhaps it is too young, perhaps it needs more time and more development. The hope remains, something GibsonGraham deserve a lot of recognition for reinvigorating into the pessimism of Foucault's post-structuralism.

The originality of Gibson-Graham's work has to be the combination of a deep understanding of Marx without being beholden to vulgar, narrow, or rigid interpretations of him, with the poststructural theories of Derrida, Foucault, Mouffe, and Laclau, interspersed throughout with a more geographically-sensitive Third-wave feminism. To me they read as post-structural humanist (in a very broad and contingent sense) Marxists. An enlightened combination, invigorated by the spirit of praxis and activism, that through their work they have shown is absolutely necessary for the development and achievement of a post-capitalist politics. 
For Gibson-Graham, class needs to be explicitly de-essentialized and viewed as "a potential effect of politics, rather than merely its origin" $(2001,19)$. For them, the important definitional aspects of post-structural Marxist political economy are "the way[s] that surplus labor is produced, distributed, appropriated... and also the different ways in which they are socially imbedded, constituted in each specific instance by an infinity of different "conditions of existence"” (9). Their notion of class and socioeconomics more broadly is heavily indebted to Althusser's concept of overdetermination, the key aspect of which is that social structures and behaviors and patterns are the result of an indeterminate number of stimuli and attempting to distinguish which was the primary causal mechanism is a fool's errand (though in the last instance the economy, or at least the discourse of the economy, is still assumed to be determinative). Social causation is completely different from physical scientific causation. Class is a social concept that is no more the cause than the effect of history (4-5).

As mentioned above, Gibson-Graham are extremely concerned that the discourses of monolithic, hegemonic Capitalism lead to an imaginative closure (that is a closure of the imagination, not a closure that is imagined; the closure is ontic) that disallows noncapitalist modes of exchange and labor to be hidden and delegitimized. As feminist scholars, they see fit to begin with the labor that occurs within the householdunremunerated labor that is primarily although not exclusively performed by women.

Part of Gibson-Graham's original contribution is their argument for diverse economies. Diverse economies are economic systems that include capitalist, non-capitalist, and alternative capitalist activities. This is more of a reemphasis that an alternative system, because this is what Gibson-Graham argue that we already see in existence right now. 
However, the nodal or focal point of the global economies is still broadly capitalist. Capitalism is the avenue through which conventional and material power and resources inevitably flow, at least increasingly so over the past hundred or so years. Gibson-Graham in their scholarship and their non-academic lives have engaged in projects attempting to offer a new nodal point for global economics, the community economy.

The foundational premise of the community economy is interdependence, not profit maximization or competition (the two foundational principles of the capitalist nodal point)(Gibson-Graham 2006, 79-81). For Gibson-Graham, the hegemonic capitalist discourse perpetuates the ideology that we are discrete individuals who are born individuals and exist individually, but this is not actually the reality. Drawing from Jean-Luc Nancy, they argue that we are distinct individuals, but socially and communally imbedded and constructed. ${ }^{96}$ We are social beings who come into the world not alone but with and among others. We are distinct but interconnected. There is no "I" without the "we." Capitalist discourses focus on the "I"; community economic discourse emphasizes the role of the "we" within the "I" and the "I" within the "we" (81-83).

"Queering globalization" is not enough, though (Gibson-Graham 1996, Ch. 6). It is important and has manifold strategic value in regard to resisting and exceeding globalization, but focusing strictly on the discourse of capitalism and its phallocentric patriarchal dimensions does not do enough to speak to the actual realities of globalization. Resist the discourse, but the emphasis on discourse does not go far enough. Building alternatives is also not an adequate supplement, especially if those solutions remain local in nature. The emphasis on discourse should be taken a step further to include an emphasis

\footnotetext{
${ }^{96}$ See earlier mention of Balibar's concept of transindividuality for a similar argument.
} 
on the pathological normalization of the capitalistic mentality that travels with capitalism via globalization. Gibson-Graham's focus is on creating new conditions that are noncapitalistic primarily by building on existing non-capitalistic practices (at least the ones that are worth maintaining like cooperatives and household labor, the goal being to disentangle these practices from the actually-existing normalized capitalistic practices that form the core of the economy). It takes new people, new subjects, with new mentalities to build and maintain these new conditions, and this is the moment of the positive dialectical progression (though in a non-teleological sense). These new subjects are created through these existing cooperative activities and can be expanded and reproduced through the expansion and reproduction of these projects. ${ }^{97}$

Despite the localized character of their analysis, Gibson-Graham do offer a version of Marxism that is complementary to cosmopolitanism, despite it not seeming so at first glance. First of all, there is absolutely no privileging of the nation-state or any other political form. It is anarchic in that sense. Furthermore, the emphases on the principles and practices of cooperation and community-building have no necessary geographic limitations, and can be interpreted to demand transnational cooperation. What is also special about Gibson-Graham's contribution is that they are Marxists who embody both a broadly utopian vision and a hard-headed realism, which rejects the binary of reform and revolution in favor of (to use a term from Fromm that will be discussed in greater detail in the final section) radical reform - a reform that helps build the conditions in the here and now for when the revolutionary moment comes. Though they don't privilege any particular political form (besides democracy, which is more of a regulative ideal than a political form

\footnotetext{
97 The two main examples given by Gibson-Graham include Mondragon in Spain and E2M in the Pioneer Valley in Western Massachusetts.
} 
for Gibson-Graham), they don't eschew engagement with representative political institutions that can further the goals of a radically pluralistic postcapitalist political economy.

The strongest critics of Laclau and Mouffe, Hardt and Negri, and Gibson-Graham can be broadly contained under the controversial label "accelerationism." While many have rightfully included Hardt and Negri under this broad label given that they explicitly build on the proto-accelerationism of Deleuze and Guattari, ${ }^{98}$ I want to focus on the work of Nick Land, Benjamin Noys, Steve Shaviro, and most especially that of Nick Srnicek and Alex Williams, who have published work on the most positive version of the tradition. Accelerationism was first used as a pejorative label (and still is by Noys) to describe the work of avant-garde post-Marxist turned neo-reactionary aesthetic theorist Nick Land's deployment of Deleuze and Guattari's rhizomatic, schizophrenic, nomadic poststructuralism. Land's basic argument (presented accurately by Noys) is "a mode which deliberately suggests the exacerbation and acceleration of capitalist forms as the means to break the horizon of capital" (Noys 2013, 36). Put even more simply, we need to speed up capitalism so we can get to the next stage faster. Land, however, took this in a very dark neoliberal direction (developing a theory he calls the "dark enlightenment," which is an accelerationist social Darwinism of sorts, where the contradictions of capitalism destroy swaths of the earth and likely millions, if not billions, of people thus potentially bringing about a new world order beyond the realm of capitalism). ${ }^{99}$ Though there are more

\footnotetext{
${ }^{98}$ Hardt and Negri's early accelerationism (though this label certainly post-dates their work on the Empire trilogy), is more of a descriptive teleological vision, whereas Srnicek and Williams' accelerationism is both descriptive and highly normative; they are laying out a positive utopian vision for the future based on existing technological developments and probable trends.

${ }^{99}$ For the full text of Land's perverse vision see http://www.thedarkenlightenment.com/the-darkenlightenment-by-nick-land/.
} 
moderate readings of accelerationism that are not quite so reactionary, they all still fit within Noys interpretation of accelerationism as simply the complex theoretical justification for the reproduction and maintenance of neoliberal capitalism. Noys views the path to utopia through gross dystopian expansion of the deterritorialization and deregulation of capitalism as extremely dangerous and at best status-quo oriented. I read Noys' critique of Land as saying that there is no reason to think that the perpetuation and expansion of the logic of capitalism would produce anything but more capitalism, and perhaps global catastrophe, but then why would that take us beyond capitalism and not a resurgent, hyper-barbaric capitalism? Why not to a time before capitalism, depending on the degree of the catastrophe?

This is where Srnicek and Williams come in with what Noys refers to as an antiaccelerationist accelerationism (presumably because of their overt rejection of Land and much of Deleuze and Guattari's assemblage theory-based accelerationism). Their "Manifesto for an Accelerationist Politics" and most recent book building off that Manifesto, Inventing the Future: Postcapitalism and a World Without Work, takes Noys' critique seriously and turns accelerationism into a properly Marxist direction. Srnicek and Williams take Land's initial starting point, which everyone seems to agree is actually with Marx and Engels. Marxian theory takes the technological efficiency, post-scarcity, and supposed development of worker solidarity as the preconditions for both the end of capitalism and the development of socialism. Srnicek and Williams offer less of a critique of capitalism that is often characteristic of Marxist theory, but instead offer an excellent critique of the (failures of the) contemporary Left (including Hardt and Negri and J.K. Gibson Graham), which they broadly label folk politics - a kind of ostensibly radical 
politics that articulates a localized vision that ends up fetishizing the local at the expense of looking at the bigger cosmopolitan project (cosmopolitan here is my word, not theirs, but that is precisely what they are talking about). The central policy proposal of this instantiation of accelerationism is the universal basic income (UBI), which provides a living wage to every person regardless of employment, wealth, age, or other status category. The function of the UBI is to separate work from wages and income, which, as was detailed in chapter two, is the defining characteristic of the capitalist mode of production. This policy, while often supported by conservatives, including Milton Friedman, because it allows people to have complete control over the stipend, also allows for the eradication of other welfare state programs like unemployment, food stamps, and welfare programs more broadly that supplement incomes of the poor (usually with children) for certain legally-determined periods of time. The UBI, in order to be a truly radical and indeed revolutionary policy, must be combined with a whole host of other programs including well-funded, free elementary, secondary, and higher education and universal single-payer health care (Srnicek and Williams 2015, 117-127).

Beyond the critique of folk politics, the authors of Inventing the Future address precisely that topic through their post-work utopia. Put simply, the argument is that capitalism produced great advancements in technology that increasingly make workers' labor time more efficient and thus less valuable to business owners. This process of automation is driven by the very demands of capitalism for efficiency, but what it also produces is a situation where work can become irrelevant and unnecessary, opening the possibility of what Marx called the realm of freedom, beyond the realm of necessity. "In many circles resistance has come to be glorified, obscuring the conservative nature of such 
a stance behind a veil of rhetoric. Resistance is seen to be all that is possible, while constructive projects are nothing but a dream. While it can be important in some circumstances, in the task of building a new world, resistance is futile" (47). The mechanism for this transition, in regard to strategy, is an expansive all-of-the-above approach, even giving an important place to the folk political strategies they criticize. Building affective bonds through local direct action, protests, strikes, occupations, and cooperatives is important, but these bonds are only the first step in exercising genuine democratic political power (that is, without also hyper-fetishizing anti-hierarchical horizontal direct democracy, something they also criticize strongly) (7-12; 26-29).

Accelerationism in this mode articulates a countervailing universalism to the universalizing and totalizing processes of global capitalism. As George Ritzer has argued most forcefully, capitalism is very adaptable to local particularities and cultures. Capitalists can always find things to commodify in a way that is in line with local practices. ${ }^{100}$ Srnicek and Williams agree strongly with this observation. And contra Gibson-Graham's argument that localized non-capitalist practices can form the basis of a potentially successful postcapitalist project, accelerationism aims to posit a critical universalism that is truly liberatory, in a way that seeks to undermine capitalism's practices of commodifying local practices and traditions without becoming destructive to those local practices that are not themselves oppressive. Accelerationism refuses to fetishize the indigenous or local at the expense of emancipation (e.g., there is really no need or rational justification to maintain female genital mutilation after all — the prime example of an oppressive localized practice). So, in addition to the classical Marxist goal of an internationalist strategy that moves

${ }^{100}$ See the McDonald's menu example in the previous chapter. 
beyond the nation-state system, accelerationism is also universalistic in a way that is consistent with the cosmopolitan project (75-83). Accelerationism in sum calls for "[a] counter-hegemonic project [that] will therefore seek to overturn an existing set of alliances, common sense, and rule by consent in order to install a new hegemony. Such a project will seek to build the social conditions from which a new post-work world can emerge and will require an expansive approach that goes beyond the temporary and local measures of folk politics" (133).

Shaviro (2015) adds to Srnicek and Williams' conception of accelerationism an aesthetic dimension. For Shaviro, and this is something that underlies Srnicek and Williams' contribution, that there needs to be an imagination, a vision of the future, and this imagined vision for the future aims through capitalism to get out of capitalism represented and maintained in art. "Accelerationism is a speculative movement that seeks to extrapolate the entire globalized neoliberal capitalist order. This means that it is necessarily an aesthetic movement as well as a political one. The hope driving accelerationism is that, in fully expressing the potentialities of capitalism, we will be able to exhaust it and thereby open up access to something beyond it" $(2015,3)$. Without doing violence to Shaviro's understanding of accelerationism, acceleration demands a new kind of thinking — thinking through capitalism — beyond capitalism and the current iterations of conventional representative politics embodied in the nation-state (7). Accelerationism works within capitalism to move beyond capitalism, and the aesthetic dimension of that project is also an aesthetic and indeed psychological endeavor.

It is precisely this kind of imagination that is restricted by the capitalistic mentality, which functions as a socialization, normalization, and reproductive mechanism for 
capitalism. By conditioning the subjects of capitalism to think in terms of instrumentalized, commodified accumulation and normalized hyper-competitiveness, thinking beyond these strictures becomes sacrilegious and unprofitable (unless of course you happen to be one of the few writers who can make a living wage doing it). Thinking beyond capitalism is at best viewed as a sign of unsophisticated naiveté. Shaviro, Srnicek and Williams all fail to see how capitalism restricts and limits the kind of thinking that is most likely to achieve the goals of a postcapitalist accelerationism, whether economically oriented or aesthetic or political. ${ }^{101}$ The capitalistic mentality conditions a lack of non-instrumental reasoning, the exact kind of creativity that Adorno broaches in his Aesthetic Theory and Fromm details in To Have or To Be?. Beyond the capitalistic mentality, though certainly co-constitutive of it in the postmodern era, is Crary's concept of "24/7." If accelerationism is meant to cut with the grain of capitalism, to split the wood in half as it were, the accelerationist technologies that produce that split also produce a kind of technologically desensitized hyper-individual, that is conditioned by capitalism endlessly, even into one's sleep—when it is allowed in our hypercaffeinated, HD LED liquid crystalized Bluetooth world (Crary 2014)..$^{102}$

The path towards the goal of postcapitalism, achieved through cosmopolitan class struggle must be aimed at unlimited democracy, against what Luxemburg calls "formal" or "bourgeois" democracy, which unnecessarily limited democracy to a certain subset of people with legitimate power through a limited set of strictly "political" procedures and

\footnotetext{
${ }^{101}$ This is all the more surprising given the $20^{\text {th }}$ century origins of accelerationism in the psychoanalytic post-Marxist theories of Lyotard, Deleuze, and Guattari. For these more contemporary thinkers, where psychology is mentioned, it is never given any significant emphasis.

102 A very creative imagining of where this trend could take us is depicted in "Fifteen Million Merits," episode two in season one of the originally-British TV show Black Mirror, which is now perhaps ironically owned by the Internet streaming site Netflix.
} 
institutions (Luxemburg 2006, 219-221). While there is no immediately clear way to get to where we need to be with regard to the psycho-social manifestation of a new mode of production, expanding our aesthetic imagination and vision seems like a fruitful first step. In order to achieve this, and one of the very first functional goals of Critical Theory, the existing conjuncture must be demystified: to help more and more people see precisely the limitations and productive alienation that the current mode of production (re)produces.

While I have mostly covered the development of this broad post-Marxist tradition chronologically (though many of these thinkers produced their theories and continue to expand and alter them over the course of an entire career), I want to end with the thinker who offers the most explicitly cosmopolitan or cosmopolitical approach to Marxism, Etienne Balibar. This overlap between cosmopolitics and Marxism is at the heart of Balibar's reading of Marx and is the main reason why James Ingram (2013) uses Balibar's theory to supplement his own conception of radical cosmopolitics, detailed in chapter one. What is important to be reminded of is that for Ingram, as we saw with Laclau and Mouffe, and we will see somewhat with Balibar, social antagonism is the ontological basis of human collective existence; no single category of antagonism, such as class, can or should be privileged over any other. However, Ingram misses an important element of Balibar's oeuvre in his many references to him, namely the critique of capitalism and the critique of capitalism as the central tenet of any radical theory of democratization. ${ }^{103}$ What makes Balibar's contribution so crucial to my project is that he is the one thinker who has actively

\footnotetext{
${ }^{103}$ This is both surprising and unsurprising. In his Radical Cosmopolitics, which is indebted to the work of Balibar, actually only cites one of Balibar's texts (Masses, Classes, and Ideas), and while it covers a large amount of Balibar's approach including what I will be discussing in this subsection, the emphasis on capitalism that was the focus of Balibar's for the early part of his career, until the past decade or so, where his focus has shifted to more explicitly political questions. Interestingly enough, Balibar's Equaliberty, which is translated by Ingram still makes note of the importance of capitalism and class struggle (Balibar 2014).
} 
and consistently theorized at the intersection of existing political institutions (national, regional, and global) from a post-Marxist perspective, without being dismissive or, on the other hand, legitimizing these existing institutions (Robbins 2013).

What is implicit in all of these post-Marxist theories is the idea that class is still important, though it is complicated by a variety of other important and occasionally more important social antagonisms (e.g., racism, sexism, etc.). What is also clear is that the old reading of Marxism as a kind of predetermined binary class theory with rigid definitions is outdated, though not completely. As Erik Olin Wright has said, "class matters." Also relevant here is Wright's theory of contradictory class positions, which emphasizes the importance of building solidaristic relations through social movements and organization that may even transcend class boundaries.

Broadly speaking, Wright's work provides a useful argument for an open-minded approach to achieving alternatives to capitalism to be judged according to his "socialist compass" (Wright 2010, 128-129). The socialist compass represents "taking 'the social' in socialism seriously" and experimenting with old and new strategies for bringing social ownership of the means and products of production to fruition. For Wright, class as conventionally understood is analytically shallow and generally not useful for the contemporary late capitalist economic system. A more open and diverse notion of class takes into account where the surplus value in monetary terms is being utilized, where it is accumulating, who it is empowering, and what is it being used for. Classes are less homogenized than they were in Marx's time and thus in Marx's theory; Wright understand that as classes have diversified, they have not become any less central to capitalism and our understanding of its logics and dynamics (Ch. 3). While offering a more nuanced 
understanding of class, Wright, when he uses the term class, still deploys the concept in a conventional Marxist way. However, class and class struggle have both been poisoned by the popular historical memory of the supposedly failed Marxist communist projects of the twentieth century and by the fact that our world looks very different than it did in the nineteenth century.

Wright's work oscillates between optimism and pessimism, but through the book he emphasizes possibility. The central argument of Envisioning Real Utopias is an amalgamation of a lot of work done by other scholars and presented in an easy to grasp way. The main strength of the book (besides its readability) is that it transforms much of the political economic nuances offered by many post-Marxists and more specifically poststructuralists who called for less deterministic, less-essentialized, less universalizing language. Wright found a way to incorporate those destabilizing theses into his overarching rationalist-analytical argument. However the only hope he offers is in the form of openmindedness on the Left and the hope that as people become aware of the successes of non/post-capitalist activities, people will become increasingly emboldened to open up more spaces and takes chances with alternative socioeconomic practices.

Wright goes on to explain the three strategies for achieving social control over economic powers. Each has its own merits and drawbacks, but his main goal is to put these left post-/anti-capitalist strategies, typically employed by divergent ideological factions, into a mutually beneficial conversation with one another. The transformational models are: 1. Ruptural, 2. Interstitial, and 3. Symbiotic. Ruptural transformations attempt to achieve broad social empowerment through revolutionary activities that "attack the state" in various ways. Interstitial transformations (metamorphoses), typically attempted by 
anarchists, involve ever-expanding "social movements" and organizations that "build alternatives to the state." The prime example of this discussed by both Wright and GibsonGraham (2006, Ch. 5) is the Mondragon collective based in the Basque region of Spain. ${ }^{104}$ The third transformational model, symbiotic metamorphoses, is broadly associated with social democrats or democratic socialists and utilizes unions and labor organizations as well as broader social movements to engage with the state through legal procedures. This third strategy involves direct collaboration with the bourgeoisie and other governmental institutions in legitimate forums. It is more or less reformist (see chart in Wright 2010, 304). As I stated, Wright points out the benefits and pitfalls of each, but what is most important is that each model can be deployed strategically depending on the context and socio-political climate at a particular point in time so that the means to achieving the ends are as successful as they can possibly be.

As Wright correctly points out, we have to constantly grapple with two truisms: Where there is a will there is a way (and the converse, where there is no will, there is no way) and secondly, the road to hell is paved with good intentions. As he says, just because there is a will does not mean there is a way (Wright 2010,6). The problem is the capitalistic mentality and the broader ideological, material, and discursive conditions of capitalism make it (literally, according to Fromm) insanely difficult to adequately think about how to

\footnotetext{
${ }^{104}$ The Mondragon Corporation is a mostly horizontally-organized collection of worker cooperatives that is also a multinational conglomerate with multi-million euro annual revenue, which is operated on the basis of worker control and democratic production - though obviously still within the confines of the global capitalist system. Though it has existed for decades and has played a role in facilitating the development of worker collectives and cooperatives in other countries with some success, they have yet to make a major dent in the overall global capitalist structure. With that said, the success of the business model offers good reason for hope and pessimism. First, it shows people that alternatives to exploitative relations of production are practicable in the immediate present. Second, it shows how such practices are not necessarily contagious nor do they represent a fundamental challenge to the global system.
} 
develop good intentions and how to make sure we aren't paving the way to hell as we aim to understand the seemingly insurmountable, but necessary, path ahead.

Etienne Balibar's neo-/post-Marxism, as mentioned above, is the ideal place to end this tour of contemporary Marxism that is aimed at highlighting its anti-/post-capitalist cosmopolitan dimensions, because that is precisely what he does in his own work (something that James Ingram seems to have lost sight of in his use of Balibar in his conception of "radical cosmopolitics"). ${ }^{105}$ Though the explicitly Marxist and post-capitalist dimensions of Balibar's work have taken a less central role over the past decade or so, there are still strong references to that tradition as well as substantive elements of it within Balibar's project.

Taken as a whole, Balibar's project is a Marxist one - a Marxism without a hyperfocus on class, but without dismissing or ignoring the structural power of class. He rearticulates the idea of the dictatorship of the proletariat as mass democratization, as it was initially meant by Marx (and reiterated by Karl Kautsky [1976]). It refuses to legitimize existing political institutions, but it also refuses to dismiss them. Balibar, in a lot of ways echoing what Adorno wrote in his essay "Reflections on Class Theory," views capitalism as fundamentally structuring, but not exclusively so; classes while they certainly retain relevance, do not have the visibility or coherence that perhaps they once did (Adorno [1997] 2003; Wallerstein and Balibar 1991, 156-157). For Adorno, “The immeasurable pressure of domination has so fragmented the masses that it has even dissipated the

\footnotetext{
${ }^{105}$ Ingram is not completely off base by not discussing capitalism in any serious detail, nor is he wrong to not use the concepts of class struggle or even the dictatorship of the proletariat which I will get to shortly, because as other scholars have noted, Balibar is critical of the reductionist deployments of this concepts. For Balibar, these concepts may not be useful because of their problematic histories and their association with reductionism. Bruce Robbins (2013) shares Ingram's interpretation (see https://nplusonemag.com/issue-16/reviews/balibarism/).
} 
negative unity of being oppressed that forged them into a class in the nineteenth century.

In exchange, they find they have been directly absorbed into the unity of the system that is oppressing them. Class rule is set to survive the anonymous objective form of the class" $(2003,97)$.

Two quotes express Balibar's perspective on class struggle and share affinities with Adorno's perspective quite clearly: "[W] hat history shows is that social relations are not established between hermetically closed classes, but that they are formed across classesincluding the working class_-or alternatively that class struggle takes place within classes themselves" (Wallerstein and Balibar 1991, 171). As we saw with Wright, the language of class is maintained, while the reductionism is eliminated and the complexity of late capitalism is embraced - without eliminating the focus on capitalism itself. Second:

There is no fixed separation, even in terms of tendency, between social classes....Let us accept once and for all that classes are not social super-individualities, neither as objects nor as subjects; in other words, they are not castes. Both structurally and historically, classes overlap and become meshed together, at least in part. In the same way that there are necessarily bourgeoisified proletarian, there are proletarianized bourgeois. This overlap never occurs without there being material divisions. In other words, 'class identities', which are relatively homogenous, are not the result of predestination but of conjuncture. (179)

What makes Balibar's work so crucial, and why it is worth repeating why Ingram's de-Marxification of Balibar is so problematic, is that Balibar never forgets the primary importance of capitalism, even if he complicates it and criticizes certain popular versions of it. Capitalism is never ignored in Balibar's work, and what I will present in the final section here, and this make Balibar's early work on the dictatorship of the proletariat more important than ever. Both the concepts of class struggle and the dictatorship of the proletariat rearticulated as unlimited democracy, accurately and dialectically understood, 
can serve to remind cosmopolitanism that capitalism is the primary antagonist of global justice and genuine emancipatory progress.

His argument, carried through his work, which takes a variety of forms, can be best felt in his most recent collection of essays entitled Equaliberty (2014). Equaliberty is at the core of Balibar's revolutionary constitutionalism. This concept refers to the dialectical relationship between equality and liberty. They are viewed here as two sides of the same coin. This is just one of the many examples of Balibar himself, though with no reference to Adorno, deploying concepts negative-dialectically. It is the struggle for equaliberty that motivates class struggle, which for Balibar is also understood negative-dialectically. There is a comprehensive rejection of any kind of teleology or universal subjectivity that will liberate humanity. Capitalism is still viewed as a primary structuring force (building off of the concept that he and his mentor Louis Althusser developed in their collaborative work Reading Capital) but the development of history and the structure of society is still overdetermined, but in the last instance capitalism (or whatever the economic system or mode of production is, is determinative).

Class struggle in the late Balibar (2014) is embodied in the idea of citizenship. Citizenship, in a vein similar to what Benhabib argues with regard to the right to have rights and democratic iterations, provides the opportunity for radical reconstruction of politics and political institutions (Balibar 2014, 8-10). Once constitutions are established, there is always a regression that Balibar calls "de-democratization," and the function of social movements (which again seems to be Balibar's more recent way of capturing the idea of class struggle) is to re-democratize constitutions, and this often takes the form of a revolution or insurrectionary movements $(2014,35-51)$. For Balibar this concept of 
citizenship as potentially revolutionary is historically always aimed at attaining the proper identity of equality and liberty (i.e., equaliberty).

In Balibar's earliest solo work, he conceptualized this goal as the dictatorship of the proletariat, which is meant to signify, as it did for Marx and Kautsky, and even Hal Draper ([1968] 2001), nothing other than the comprehensive and complete democratization of all aspects of society, especially the economy (Balibar 1977, 18-19, 111-113). This is where I want to take the final section here. I want to take Balibar's earlier work, alongside that of the other neo-/post-Marxisms detailed above, and look at the ideas of class struggle and unlimited democracy as embodying a cosmopolitan democratization that refuses to ignore the fundamental antagonist to democracy that is capitalism, including its destabilizing psycho-social dimension (the capitalistic mentality).

Recall in chapter two on the capitalistic mentality, it is shown that there is no necessary distinction in the impact or consequence of the capitalistic mentality in regard to one's class position (contradictorily understood or not). That is, capitalism is indeed a complex class-system, but the social-psychological effects are not class specific in any revolutionary way (despite the disproportionate material benefits that the capitalist class reaps and the disproportionate pains that the workers and unemployed bear). Balibar gives pride of place to political struggle while maintaining the implicit perspective that the workers are the fundamental subjects of ideology, and even if we expand this vision beyond economic class, the oppressed are the ones subject to ideology (Althusser and Balibar et. al. 2016). This is why they don't revolt. While the theory developed in chapter two, based on Adorno and Fromm, suggests that this is true, what is also true is that the bourgeoisie are always-already subject to ideology, as well. They were children once after all, and 
maybe they weren't even born into the bourgeoisie; maybe they pulled themselves up by the bootstraps and somehow made it into the bourgeoisie. Why did they want to? Ideological conditioning, similar to what Althusser calls interpellation, which produces the capitalistic mentality, is the answer. What do we do now that we know that both the proletariat (or any oppressed people) are equally subject to the ideological conditions that keep the boot on their necks as the people who oppress them? Ideological conditioning, the psycho-social permeation of human life, of the life-world by the pathological and reified demands of the capitalistic mentality means that it is just as likely that the oppressed will revolt as it is that the oppressors will cease to oppress them (literally both are roughly equally likely under conditions of hegemony at least where the oppressed are given some pittance for complying). Additionally, the oppressed here in this context could very well be workers, since they have most to gain materially, but it could also include pettybourgeoisie service employees, stay-at-home moms and dads, university students of middle class families, and small business owners. A negative dialectical reading of class demands that it be understood as porous, incomplete, and excessive (in this case, focusing particularly on how it relates to the production of revolutionary consciousness). Class identity, as the post-Marxists have argued, must be placed along other categories of identity and social antagonism in order for a more coherent and successful radical democratization to occur. What is also important to note, and something that is underemphasized in the work of the neo-/and post-Marxists is, as I detailed in chapter two, the degree to which all people within capitalist systems are shaped by the capitalistic mentality-regardless of their other particular identities or class position - though one's identity or class position may shape the specificity of the capitalistic mentality's manifestation in one's life. 
All of these post-Marxist theories have something important to teach us when combined with the work of Adorno and Fromm and the reconstructed concept of the capitalistic mentality. The lesson is that revolution is exceedingly unlikely under the depraved but not too visibly depraved conditions of late capitalism. People still believe in capitalism, whether they understand it or not. In other words, people have more to lose but their chains, like the unlimited data plan on their iPhones (Crary 2014).

Broadly speaking, the capitalistic mentality, in a manner quite similar to its effect on cosmopolitanism and democracy more generally, undermines the ability to build a counter-hegemony, to see the ideological dimensions of our own lives, to work together creatively against Empire, to build local non-profit collectives within a broader capitalist system, and to reappropriate the most recent developments in technology for noncapitalistic or post-capitalistic usage.

What all of these theories agree on, regardless of their particular view on class, is that the social fabric is at least to some degree produced by capitalism and therefore the structures of our societies are infected by capitalism, but what they all fail to take into account is that people are themselves infected by capitalism. People are made helpless to a large degree, unable to locate their malaise in the "hyperobject" that produces it (Morton 2013). ${ }^{106}$ Capitalism has become beyond comprehension, and it has deluded even the most sophisticated and original Marxist thinkers from seeing that capitalistic people are not ready for postcapitalism. In fairness, they never explicitly say anything to the effect that all we need to do is get past capitalism and everything will be fine. They all grant some role

\footnotetext{
${ }^{106}$ In Timothy Morton's (2013) work, hyperobjects are systems of objects that are so large and complex that thee exceed human comprehension, unlike tradition object. Examples of hyperobjects include global capitalism and the global environment.
} 
for the subject being produced by capitalism (along with other social antagonisms), but they all fail to take that opening to its negative dialectical conclusion: we are not ready for capitalism to be over. This is why cosmopolitanism combined with class struggle is absolutely crucial. Cosmopolitanism, as a reformist approach, gives people the time and opportunity to struggle together and build against the capitalistic mentality without having to be terrified of immediate drastic systemic changes-no matter how normatively necessary those changes are, because such drastic changes induce a fear that impedes the necessary change.

Accelerationism reminds us that our unlimited data plans and the other recent developments in nanotechnology, cybernetics, and automation have opened up the nearpossibility of a world without meaningless work, but first that that unlimited data plan can be used to organize collective resistance, to build movements. If, as Ingram (2013) suggests, a radically democratic cosmopolitanism must be a cosmopolitanism from below that works within and against existing national and transnational political institutions, it also must be a cosmopolitanism that uses the tools of capitalism against capitalism. This takes Hardt and Negri's notion of the multitude and re-territorializes it somewhat, in a way close to what J.K. Gibson-Graham suggest. ${ }^{107}$ Left movements must start local. They will always have local manifestations, and while advanced social media technologies can bring people together from long distances, solidarity is best built in the workplace, around the neighborhood, at the local Farmer's market, or even the mall. ${ }^{108}$ What Balibar, Srnicek and

\footnotetext{
${ }^{107}$ In Declaration, Hardt and Negri move from their initial position in Empire, arguing that face-to-face political engagement is much preferred to mediated interactions through social media in regard to building successful movements.

108 Technological developments that spring from capitalism cut both ways though. Even the solidarity and human connections that could be built through the collective activity of shopping is undermined by the advent of Internet shopping (Crary 2014).
} 
Williams, Hardt and Negri, and Laclau and Mouffe argue is the political and social protest movements, the actual acts of struggling together are still the best tried-and-true methods of building a solidarity that can be an effective tool against oppression in service of emancipation. Only Balibar gives emphasis to working with political institutions though.

\section{Radical Realism and Radical Reform: The Contours of Reconciling Cosmopolitanism and Marxism}

If the point of all of this is to achieve global justice and this demands moving beyond capitalism, as I have theorized in the previous chapters, and we want to get there as fast as is humanly, humanely, and thus as realistically as possibly, we need a multifaceted approach that builds on the best strategic prospects and existing political, social, and economic realities we face. The solution offered here is class struggle without an emphasis on class despite it taking place within a class system, accelerating through cosmopolitan structures, towards unlimited democracy. This project is one of radical reformism; we reform our socioeconomic system to move beyond the current neoliberal capitalist system through a radical democratization of our existing political systems aimed at comprehensive popular, social control over and within all aspects of society. If this is not global it will not be successful, and this means building on the existing alterglobalization networks (e.g., transnational socialist parties and the World Social Forum, but also perhaps more secretive and criminal organizations like Anonymous and Wikileaks), ${ }^{109}$ but it also means reappropriating (i.e., democratizing) the capitalist globalization networks. That is, the Left must truly use the masters' tools again the master.

\footnotetext{
109 These organizations can serve the purposes of democratization by destabilizing the existing hegemony that individually and systematically undermines existing demands for genuine democratization.
} 
If global democratization is the fundamental goal of normative cosmopolitanism, and since that goal is exceedingly unlikely to be accomplished through revolution or mere reforms within capitalism, radical reform represents the best guiding principle for a truly radical cosmopolitanism.

What does radical reform mean more broadly though? According to Fromm, ${ }^{110}$ radical reform refers to a dialectical reading of the typical Marxist binary of reform and revolution (or what Fromm terms "radicalism") (Fromm 1955, 17). Radical reform means instituting crucial social, political, and economic changes that aim to move society closer to the moment of transition and-through the organizations and movements necessary to achieve the radical reforms - prepares them for the transition itself and for society after the transition. In the context of this project, radical reforms are reforms that prepare people, and the social system more broadly, for the transition to postcapitalism and indeed move them closer to it. The goal of this kind of reform is not reform, but instead, revolutionalbeit a revolution that takes place over a generation. ${ }^{111}$

For Fromm (and this is putting his argument somewhat into the negative dialectical language of Adorno but is entirely consistent with Fromm's actual language on the subject, which I will return to shortly), this is both dialectically inconsistent and a false dichotomy. First, reform is not actually reform if it functions as a temporary Band-Aid for the ills of society and the crises of capitalism. Revolution is also not revolutionary or cannot be

\footnotetext{
${ }^{110}$ As far as I have been able to find, in the English language, the first person to use the concept of radical reform and to provide a coherent definition of the concept is Erich Fromm. After 1955 when Fromm first used it, Ralph Miliband used the phrase quite often to speak of the kinds of reforms that Marx lists in the Communist Manifesto, though I am not sure if Miliband was aware of Fromm's previous usage. The use of the terms seems consistent though (Miliband 1977; 2015).

${ }^{111}$ There is somewhat of an overlap here with Trotsky's concept of permanent revolution, though it differs in a preliminary rejection of democratic centralism or any kind of potentially undemocratic elite-driven radical movement.
} 
revolutionary if it does not take place somewhat gradually. That is, if people are deeply conditioned by capitalism, abrupt insurrectionary takeovers of the State and economy will fail because the people are not psycho-socially prepared to participate in a postrevolutionary society; they are prepared to participate in capitalism (or whatever the preexisting society was at a given point in time). Revolution takes time because it takes time and experience to build the revolutionary mentality necessary to live in the postrevolutionary world, and probably in the revolution itself. Anger spawned by injustice and depredation is enough to motivate people to revolt, but it is not enough for them to revolt successfully.

Fromm tells us:

There is reform and reform; reform can be radical, that is, going to the roots, or it can be superficial, trying to patch up symptoms without touching the causes. Reform which is not radical, in this sense, never accomplishes its ends and eventually ends up in the opposite direction. So-called "radicalism" on the other hand, which believes that we can solve problems by force, when observation, patience, and continuous activity is required, is as unrealistic and fictitious as reform.... The true criterion of reform is not its tempo but its realism, its true "radicalism"; it is the question of whether it goes to the roots and attempts to change causes - or whether it remains on the surface and attempts to deal only with symptoms. $(1955,273)$

Contrary to what Laclau and Mouffe, Hardt and Negri, and Gibson-Graham argue, I want to privilege capitalism (because it privileges itself so to speak). Contrary to the standpoint epistemology of Marx and Lukács, but like the neo- and post-Marxists, I do not see the working class as a universal subject nor as the necessary locus of revolutionary consciousness. I do not see the proletariat as holding a privileged epistemological perspective from which to see the oppression inherent in capitalism (though they certainly objectively experience exploitation, the issue is particularly whether the experience of 
exploitation is experience consciously as exploitation). Maybe that could have been true before, and maybe it might still be true in the developing world where capitalism looks and functions closer to how it did in the nineteenth and early twentieth centuries in the United States and Europe, but the subject of capitalism more broadly must be seen as the universal subject (that is, the subject embodying the capitalistic mentality, because if not them, who else?). Solidarity must be built across conventional class lines, but building on the principles of class struggle and unlimited democracy—simply meaning, democratization against capitalism.

The capitalistic mentality gives all people a radical potential because it equally, though unevenly, conditions all those who live under and within capitalism. Contrary to Laclau and Mouffe's, Hardt and Negri's, and J.K. Gibson-Graham's empty subject and discursive anti-humanism, it is because, under conditions of relative abundance, one's position in the class system does not determine or significantly condition one's ability to live a contented life. There are billions of unhappy people, but the degree of unhappiness is not correlated with one's position in the relations of production. Those who own are not necessarily happier than those who work. They have more things. Shinier gizmos. More bigger, shinier things. ${ }^{112}$ With that said, those with their basic necessities met will certainly have a great opportunity for happiness and fulfillment than those who are starving or homeless. Resistance emerges from some form of profound dissatisfaction. Dissatisfaction is mediated by norms and social expectations, as Fromm (1991) argues, and it is mediated by ideological conditions as Adorno (1976) details (e.g., if we identify success with more things, the more things we have the more successful we will feel). However, this is

\footnotetext{
${ }^{112}$ See "Can Money Buy Happiness?" (http://www.wsj.com/articles/can-money-buy-happiness-heres-whatscience-has-to-say-1415569538)
} 
precisely where the importance of Fromm's normative humanistic psychoanalytic perspective is crucial (Fromm 1955). Human beings have broadly defined psychological needs and preferences. We need to be able to express ourselves. We need to feel connected to people (both to our society and strangers to some degree, but also to our friends, family, and beloved(s)). We need to feel like we can improve both as an individual and as a member of society. These demands can be filled in variety of ways. Some social systems meet some of these demands better than others. Capitalism promises to meet them all and fails in most respects, though not all. ${ }^{113}$

It is from the potential dissatisfaction, the distance between the capitalistic mentality and the broader psychological needs of human beings, from which resistances to capitalism could be born. There is a big catch though, and some important fine print we should take note of. People need to recognize that distance, associate it accurately with capitalism, feel like they can actually effectively work towards changing it, know and believe that there is a viable alternative, trust that other people will work with them towards that goal, and finally everyone must avoid the excessive use of shallow, fleeting, therapeutic measures that capitalism offers us so inexpensively. "Embrace your pain and discontentment, even though there are temporary solutions that will help somewhat and permanent solutions are realistically unlikely to come about anytime soon" doesn't make for a great recruiting slogan.

E. P. Thompson's (1963) conception of class as experience is both affirmed and rejected here. The subjects of capitalism, in total, could form a class due to their shared

\footnotetext{
${ }^{113}$ See my review of Martijn Konings The Emotional Logic of Capitalism (2015) for a succinct analysis of how this plays out in the context of a radical reformist movement beyond capitalism (2016, available online: http://marxandphilosophy.org.uk/reviewofbooks/reviews/2016/2170).
} 
experience with the structures of capitalism that (re)produce the capitalistic mentality in a way that is not visible in the conventional Marxist understanding of class based on one's relation to the means of production. However, this is not what Thompson or any other theorist I am aware of has argued. A radicalized cosmopolitanism recognizes that the subjects of capitalism could only constitute a class, objectively, once they organize themselves against the capitalistic mentality. ${ }^{114}$ It is not one's specific class position that matters with regard to the formation of collective resistance to capitalism, but instead it is the subject's (as an alienated subject-object) existence within the class-system of capitalism that allows for all the subjects of capitalism to possess a radical potential (albeit an extremely tenuous one--and the degree of tenuousness is indeed connected to the specificity of the class position among other ascriptive categorizations).

\footnotetext{
${ }^{114}$ Why would the bourgeoisie participate in a movement against capitalism, when capitalism so clearly benefits them? This is precisely why Marx argued that violence would likely be necessary; the bourgeoisie would likely never give up their dominant class privilege without a fight (while acknowledging at a certain point there may be a small number of bourgeois defectors - a likely sop to his longtime friend, collaborator, and benefactor, Friedrich Engels). This is also why Lukács (1971) argued that the bourgeoisie could never attain true, class consciousness, because they lacked the knowledge of the true exploitative nature of capitalism, and because their historical position as exploiters (in competition with one another) undermined the solidaristic relations necessary for class consciousness. Even if they could get around this epistemological block, such a knowledge would demand a kind of self-renunciation that Lukács believed was untenable. However, what if it were possible for the bourgeoisie to experience the deleterious effects of the capitalistic mentality and recognize its basis in the capitalist mode of production? Would that selfrenunciation, however traumatic, not function as a kind of radical therapy? Assuming the conditions of post-scarcity hold and the bourgeoisie could be convinced that their ability to sustain themselves would not be threatened (though their extraneous luxuries certainly would be - but that would be addressed by what follows...), a more humane and sustainable existence for everyone could be attained by moving beyond capitalism. This would likely involve a strong critique of the bourgeois notion of (material) self-interest that demystified the psycho-social harms that capitalism visited on all those who live within it, even those who ostensibly benefit in material ways. Climate change might offer one avenue to facilitate this process. Climate change has the potential to affect everyone on Earth, though certainly the poor are much more vulnerable as we have witnessed already in the twentieth century with the drastically unequal consequences of natural disasters. This is just a potential though. There is always the risk that history will develop closer to what is depicted in Snowpiercer (2013) and Elysium (2013), science fiction movies in which the wealthy use their privilege to "escape" the effects of ecological destruction, at least temporarily, out of the reach of the lower classes and their vengeance. This does not mean that Lukács was wrong and the bourgeoisie can definitely attain a solidaristic class consciousness in connection with the proletariat, but rather that he might be wrong now.
} 
Put less technically, why do members of the bourgeoisie behave how they do? Because they embody the capitalistic mentality as much, if not more than the proletariat. I argue that it is certainly not by choice or anything that we should want to equate with agency. The proletariat, though it certainly experiences greater deprivations and estranged labor, is subject to the same capitalistic mentality, just perhaps to a different degree (as detailed in chapter two). These contingent truths must be taken into account when considering how to move beyond capitalism. ${ }^{115}$ This approach, as mentioned earlier, must include a much more expansive notion of class. There is no reason we cannot both focus on a critique of the broader and particular harms of capitalism and be inclusionary with regard to movement-building and class struggle. Class struggle, as a concept, is nonidentical. This means, according to Adorno's negative dialectics, that it must not be reified or viewed a comprehensive. The revolutionary class could take many forms, but what is most fundamental is that it oppose capitalism and its class structures. There is ample evidence, especially with the election of Donald Trump in the US (specifically in working class areas of states such as Michigan, Wisconsin, and Pennsylvania), the Brexit vote in the UK, along with the long history of working class support for fascists in Germany and Italy and other brands of militant nationalists over the course of the twentieth-century, that being member of the working class does not necessarily produce any kind of class consciousness that is inherently radical or even worth promoting. With that said, and this

\footnotetext{
${ }^{115}$ The bourgeoisie are akin to Bane from Dark Knight Rises. Sure, they're the bad guys, but it isn't their fault. They have been conditioned by various traumas (both real and imagined) and are being manipulated by a distant, thoughtless cabal hiding in plain sight. Capitalism, like the League of Shadows, lacks agency in all substantial respects; it is imprisoned by its own logic, and thus it is precisely the logic that must be countered if the system itself it to be countered. Though it is certainly not meant to be a comprehensive metaphor/analogy for the whole movie or the Batman/DC universe, my point is to suggest that contrary to the standard Marxist understanding of the bourgeoisie and class in general, as well as the poststructural reversals, all people under capitalism are victims of and subject to capitalist ideology and the pathological pressures of the capitalistic mentality (albeit with differentiated consequences).
} 
is the contradiction here, it is still the working class that has the most to gain through a radical opposition to capitalism.

If Marx, Karl Kautsky (1974), and Balibar are correct that, dialectically understood, the "dictatorship of the proletariat" means the comprehensive democratization of the modern State, we must also take into account what William Robinson $(2004 ; 2014)$ has called the transnational State as well, both by opposition to the transnational State as such and by attempting to reappropriate its institutional manifestations. We must both embrace and resist China Miéville's (2005) claim that the rule of law can only serve the interests of the oppressors and never fully the interests of the oppressed. This is what radical reform must mean in the twenty-first century.

While this chapter offers a positive approach, it will also convey the negative possibility that its program will not be carried out. The forces of global capitalism and its ideological conditions are not to be trifled with or underestimated. Radical reform, in the context of the integration of cosmopolitanism and Marxism, must be a theory and practice of hopeful pessimism; that is, a hope without optimism. ${ }^{116}$ A hope that refuses to lie to itself or others just how far we must go and just how difficult the path will be. The utopian element of cosmopolitanism is not just in its dream of a globally-structured political system beyond the current dominance of the nation-state that is politically, socially, and economically just, but also, and arguably more so in its unfounded belief that this vision is compatible with global capitalism (Beardsworth 2011).

\footnotetext{
${ }^{116}$ On the relationship between hope, optimism, and pessimism with regard to Marxism and radical change, see Miéville (2015a; 2015b), Warren (2015) (all three in the first two issues of Salvage) and Eagleton (2015).
} 
One of the great benefits of cosmopolitanism is that it lacks a class-based analysis in its historical development. The normative cosmopolitan tradition I've been engaged with in this project is decidedly non-Marxist. Thus, it is not hamstrung by a legacy that gives so much pride of place to class. This is also connected to its core weakness, its complicity with capitalism. By refusing any corrupt view of the state with regard to capitalism, cosmopolitanism is able to see the manifold benefits of working within existing state structures (Beardsworth 2011).

As has been discussed in the introduction and chapter one, cosmopolitanism and Marxism are often treated as distinct intellectual traditions. Academically speaking, this is absolutely accurate. Normatively speaking, however, there are much greater similarities than differences between the core goals of these traditions. The language of human rights (contra Steven Lukes [1987] and others) is something that should be of interest to both traditions - which as Ingram [2013] notes, has a legitimacy that Marxism and horizontalist, workerist, and anarchist inspired radical movements have failed to cultivate or maintain among the general population. Cosmopolitan institutions exist. It is time to take them over through unlimited democracy.

What Marxism misses still—besides the importance of political emancipation as a part of human emancipation - is the destructive nature of the capitalistic mentality for its own project, and thus the importance of the revolutionary movement representing new values, virtues, and norms. Capitalistic people cannot produce genuinely democratic, humane socialism or whatever term one prefers for an emancipated or emancipatory postcapitalist society. However, capitalistic people are the only ones who can produce a humane postcapitalism. If the hegemony of (neoliberal and consumer) capitalism is to be 
defeated, there needs to be more than socialist strategy. The global Left needs a socialist strategy that eschews the dominance of strategic thinking and self-interested politicking. There needs to be more than accelerating the contradictions of capitalism; there is always the strong possibility that if acceleration is not coupled with alteration, that the accelerated contradictions will reproduce the very mentality that acceleration hopes to destabilize. There needs to be more than a discursive battle against the patriarchal-capitalistic monolith. There needs to be more than a glorification of the radical potential of the subjectivities of the Multitude against Empire. There needs to be more than largely academic philosophizing against the ideological nuances of late capitalism. These are all part of the answer. All of these approaches have something to contribute. They have all been groundbreaking in crucial ways in their time, and still today. What has been ignored or undertheorized from a praxeological point of view is the dominance of the capitalistic mentality and the affective power and influence this has on democratic political imaginations. Alienation, competitiveness, possessiveness, and reified identitarian thinking which are coconstitutive with contemporary capitalism inhibit precisely the radical vision and praxis needed to get us beyond capitalism.

While the necessity that a radical cosmopolitan realism be democratic and as egalitarian and participatory as possible is without question, there will likely always be a need for leaders, for organizers, for point-people, for the motivators. We all have different skill sets, and a movement cannot succeed based on the assumption that everyone's skills and potential contributions are identical. Power must always rest with the movement, and not with the leader. This is where Lenin's vanguard failed. This is also not completely dissimilar from the proposal that Beardsworth makes with regard to his cosmopolitan 
realism, the need for moral-political leadership and responsibility. While much more republican than democratic in its theoretical inspiration, Beardsworth's recommendation for cosmopolitan political leadership must be taken seriously, even for a radicalized version of cosmopolitanism, despite the fact that for Beardsworth this leadership is held by the most powerful nation-states, not necessarily individual leaders-though individual leaders in those countries certainly retain a major role in cosmopolitan leadership (2011, 232-237; 2015).

Leadership and responsibility are crucial. We need bottom-up activists, and we need leaders. We need leaders with vision, charisma, and who are accountable to and part of the people they are leading. The distance between these necessary leaders and the class struggle they must be a part of cannot be far. We have seen, far too often throughout history, leaders of ostensibly revolutionary movements betray the movements and peoples they have led. While this is an historical truth, it is certainly not inevitable moving forward (nor was it inevitable in the past). Leaders should be guides, organizers, and inspirers, not sources of authority in and of themselves. Democracy is still the foundational and primary principle. Political democracy. Cultural democracy. Economic democracy. Contra Hardt and Negri, leadership and some kind of radical democratic representation are not antithetical. As Žižek has opined many times in critiques of direct democracy, most people would not want to have to deal with the day-to-day management and organization of society on a daily basis (nor should they).

Even with immense technological innovation, with the Internet, smartphones, and social media, that kind of direct daily participation would likely take up a lot of time for a lot of people. There is also no proof that representation or political leadership are inherently 
flawed. It is the lack of genuine participation (which should be distinguished from an antirepresentational, radical direct democratic politics) (Mouffe 2013; Chomsky 2013). The issue is power. Where is the power? It must be with the people. Now even if power were located in the people, participation still matters a great deal. Some things, some topics, some issues should never and could never be adequately represented. Workplace democracy is a key example. ${ }^{117}$

Democracy and the capitalistic mentality are not compatible. This is the principal role of an inspiring and responsible radical leadership. This is a notion of leadership that recognizes its own potential inversions and regressions and the threat it poses to the achievement of the unlimited democracy. Class struggle without and throughout classes demands organized leadership until the capitalistic mentality is thoroughly eradicated and replaced. It is not enough for the transitional mentality to take hold. That is merely the motivation for struggle. That is the only likely possibility within capitalism. Global justice and the postcapitalism it requires must include a political, social, and economic strategy that also functions at the psychological level as well. It must work and build towards a post-capitalistic mentality, a mentality that can only be achieved as the result of and through organized class struggle — a class struggle that transcends class within a class

\footnotetext{
${ }^{117}$ We can look to Rousseau's (1978) distinction between sovereignty and government from On the Social Contract here. Rousseau was a sovereign democrat, but not a governmental democrat. He did not believe that the people should be in charge, as a collectivity, of running a society. Government for Rousseau meant bureaucratic management. Social, political, economic power and authority ultimately rested with the people (with their general will or collective common good). This is what makes Rousseau both a republican and a democrat. Governments should be run by those best suited to the particular roles that need to be fulfilled. However, power, authority, and legitimacy can only ever be held by the people (from which the government functionaries are drawn, by the way). In regard to contemporary theory, workplace democracy has been most forcefully articulated by Richard Wolff (2012) in Democracy at Work and by Michael Albert (2003) in Parecon.
} 
system. It can only be achieved through a genuinely radical, realistic, cosmopolitanism that stands opposed to capitalism and all its oppressive bed-fellows.

Perhaps there will be a time when representation or leaders are not needed or do not offer positive benefits for democracy itself. This is a laudable goal and should never be dismissed. Srnicek and Williams are right to suggest at the very least that organizational leadership is important. Perhaps this is exactly where the Left needs to do some work: thinking about precisely what leadership on the Left means. Does it mean engaging with mainstream party politics aiming to shift the discussion leftward as we've seen with Jeremy Corbyn in the United Kingdom, Bernie Sanders in the United States, Podemos and Pablo Iglesias in Spain, or even the attempts made by Alex Tspiras in Greece? Acknowledging that there is a great deal of policy and strategic diversity in this group, they are all electionoriented and are thus closer in line with the old Eurocommunist programs than they are with a truly radical or revolutionary Marxist movement. My argument here has been that radical reform demands a dialectically integration of reformism and insurrectionism (to use Ralph Miliband's language).

These politicians, while certainly unorthodox, are still politicians, and yes they could serve as moral leaders for a new New Left, it might very well be that the recently exonerated Subcomandante Marcos of the Mexican Zapatista uprising in Chiapas, Mexico in the mid-1990s offers a better example, at least before he was forced into hiding. He was a figure without a name —at least not a real name—but it didn't matter. There was leadership. He represented the movement. He was the voice of the movement, but he wasn't in charge of the movement. This is precisely why he covered his face and kept his legal identity a secret. It wasn't to evade responsibility (though prosecution maybe), but rather 
to avoid the assumption that he held some sort of greater power that the rest of the participants in the movement (ROAR Collective 2016). ${ }^{118}$ Though their identities are known, the three women leading the \#BlackLivesMatter movement in the US embody this kind of organizing leadership. They are leaders, but the movement doesn't live or die with them. The movement is a peoples' movement (Taylor 2016). They are people the media can interview, but they aren't functionally in charge in the way that phrase is normally meant. They couldn't be.

Truly democratic movements, true class struggle aimed at unlimited democracy that exceeds class and the traditional limits of political power within capitalism, would never and should never accept that conventional brand of leadership - but complete nonhierarchy is not functional today. Just look at the events of May 1968 in France or the Occupy Movement or even the Arab Spring.

Whether it is Subcomandante Marcos or Jeremy Corbyn or Bernie Sanders, while the nature of the leadership of a radical reform movement is certainly an important question, what matters is what that leadership does. It must take a stand, alongside their supporters, alongside the people. Our leaders must embrace radical changes that progressively prepare us, within and against the existing system, to move beyond the existing system, beyond global capitalism. We need to be better to do better. We need to do better so that the people who come after us can be better and do even better than we could. We need leaders who are us and who are better than us. We need leaders who push us to engage and move the center of mainstream domestic and transnational politics. We need to re-learn how to live differently in this world while preparing ourselves, our friends,

${ }^{118}$ Available online at: https://roarmag.org/2016/02/25/subcommandante-marcos-no-longer-a-wanted-man/. 
our colleagues, our children, and our comrades for a world ahead of capitalism. We need leaders who motivate people to work and organize outside of the legally-restricted mechanisms of constitutional or parliamentary power. The fight for and the establishment of unlimited democracy, which means nothing more than the pervasive democratization of all dimensions of society, demands a conventional political dimension, a fugitive political or populist dimension, and it must always leave open the possibility and indeed potential necessity for extra-legal political activities. ${ }^{119}$

The merger of cosmopolitanism and Marxism centers on three important concepts: a reconceptualized understanding of class struggle, universal democracy), and radical reform (which combines the first two with the progressive spread of non-identitarian thinking, the productive character orientation/being mode of existence in order to successfully move beyond capitalism). Cosmopolitanism, aimed beyond capitalism, offers the time, existing institutional mechanisms, and legitimacy to achieve radical reform. Unlimited democracy offers the immediate goal for radical reform, while highlighting the crucial enemy: capitalism. This achievement is the first step towards emancipation that we can reasonably imagine at this point in time (and for many readers, even this might be seen as a stretch). Class struggle is the mechanism to achieve the solidarity and experience needed to practice a truly radical reform.

\section{Conclusion}

\footnotetext{
${ }^{119}$ The situations where this would seem most obviously reasonable is when a government and/or its laws are written in such a way or made to function in such a way that they produce injustice and oppression. No people should be expected to tolerate that and accept only the legally prescribed avenues of resistance and change provided by their oppressors.
} 
If we want to get closer to the normative horizon of what might actually be agreed to in an honest non-capitalistic original position we need a post-capitalistic mentality (Rawls, Beitz, and Pogge). If we want to avoid the colonization of the life-world, we need to refuse the capitalization of the real world (Habermas). If we want to live up to the universal discursive recognition and reciprocality of the post-conventional moral reasoning demanded by discourse ethics (Habermas), of the universal and concrete other (Benhabib), we need to be able to see and embrace the humanity of the universal and concrete other. If we want to remove harm, we must understand the foundational-systemic sourcing of harm from the structures of capitalism, both materially and psycho-socially (Linklater). If we want to avoid the excessive inhumanity and the anti-democratic false universalities of modernity and postmodernity, we must embraces a radical cosmopolitanization from below and a sustained critique of the differentially-privileging and diverse manifestations of global capitalism (Cheah and Ingram). We must embrace global struggles-class structured, intersectional struggles-for liberation. They are not on the verge of success, but we can certainly say, if the pathway towards any potential global liberation movement is ever going to be visible, there is certainly hope for the Left that that visibility and even foundational construction, is getting nearer. That project will likely engage on cosmopolitan or cosmopolitical lines.

Neo-cosmopolitan postcapitalism or postcapitalist cosmopolitanism must include a reformulation of the characteristic elements of traditional cosmopolitanism detailed in chapter one and repeated at the outset of this chapter. Such a novel framework would include three categories: (1) Politics (2) Ethics, and (3) Social Economics, with important elements under each category. This framework includes praxeological (that is both 
theoretical and practical) dimensions and several overlap or are included in multiple categories (reflecting the ontological overlap and non-identity of the categories themselves):

\section{(1) Politics:}

a. Pooling of Sovereignty (including primarily the upward cession of sovereignty detailed by Beardsworth [2011], though in the case of less democratic nation-states, downward cession would be required, as well as regional pooling for more regionallyappropriate problems).

b. Cosmopolitanization from Below (including a promotion of transnational, regional, national, and subnational social movements, localized community control of cities, suburbs, and rural areas, and workplace democracy).

\section{(2) Ethics}

a. Complex Cosmopolitanism (the boundaries of nation-states are historically and politically important, but morally arbitrary. The automatic consequence of this is not that individuals - as currently conceived in the liberal cosmopolitan tradition are the sole proper locus of rights and obligations. A more socialized transindividuality as theorized by Spinoza, Rousseau, Hegel, Marx, and most recently Balibar is necessary. How this is to be done should be rooted in the political clauses detailed above).

b. Right to Participate (i.e., the right to democracy—here in a Habermasian sense, the inherent unethical nature of unjustifiable exclusion based on a strict and expansive interpretation of the all-affected principle; this comes with the correlative duty to 
encourage the participation of historically and currently underrepresented groups like racial minorities, women, LGBTQIA+ persons etc.).

c. Right to Not be Exploited (meaning in the classical Marxist sense, one's labor or dignity must not be coercively extracted by another through structural or direct mechanisms; this is combined with an ethical obligation not to exploit others).

\section{(3) Social Economics}

a. Right to One's Labor (including a duty to contribute what one honestly can so long as the broader structure of society is such that there remains some kind of additional remuneration for labor, one's labor must be fairly remunerated, even if it is democraticallycompelled labor under safe, solidaristic, and universally-applied conditions. This may include rational automation of the most unpleasant or least-volunteered for but sociallynecessary tasks).

b. Right to Basic Human Needs/Goods (and the dignity that comes with, wherever possible, luxuries beyond the bare minimum is possible for everyone who desires thembut never at the expense of basic need fulfillment for all; this must include an equitably habitable planet and access to resources).

c. Right to Progress/Develop (this includes non-commodified forms of culture, education, and other forms or avenues for the expanded development of human(e) potential).

Again, the likelihood of all or any of this is not the centrally important question Or rather, it is not the crucial question here (In fact, one of the motivations for this project is the sad reality that all of the normative goals described herein are unlikely to be achieved). 
This broader proposal must be radical and realistic if it is necessary to address the global injustices sustained by capitalism and its transnational state institutions that support and reproduce it. Perhaps pessimism is both the solution and the problem. Pessimism makes hope difficult, but it also expresses the necessity of hope more clearly and profoundly than (blind) optimism ever could.

With due respect to the World Social Forum and the courageous people who have built and organized and resisted in support of its futuristic alterglobalist vision, it is not enough to say that another world is possible. Another world, a world ahead, a world ahead of capitalism, with its technological progress and grotesque triumphalism while billions suffer, is more necessary than it is possible. To live up to Marx's timeless dictum "to each according to his need, from each according to his ability," we must not focus on the possibility of a world ahead, but rather on the necessity of a world ahead. Necessity is after all the mother of invention.

However, just because something is necessary, does not make it possible. Possibility, and the imagination it inspires, is crucial as well. Another world is possible, yes. This is an important message for the global Left, a vital message that needs to be ceaselessly articulated. However, another iPhone is possible as well, another version of Candy Crush, another version of Fast and the Furious, another version of the F-15 or B-2, another version of the assembly line, of the bread line - are all possible. We need another world. If necessity is the mother of invention, possibility is certainly its father and right now, possibility isn't paying its child support because necessity hasn't taken it to court yet.

We can't say for sure where the future is going. It is unknowable. While it may be foregone, we cannot not know, so why assume it is? That is not the pessimism a combined 
radical Marxist cosmopolitanism offers. A radical hope, to use Jonathan Lear's (2008) terminology, combined with a radical realism and a radical reformism is a hope without optimism (Eagleton 2015). It is a hope with teeth (Miéville 2015a, 188).

Now, it is up to people working within and against existing cosmopolitan regimes, already with dirty hands, to make things better while continuously opening new doors for progress. This kind of radical progressivism takes into account the impossibility of insurrectionary change in a world pervaded by the capitalistic mentality, the insufficiency of its own progressivism, and the additional necessity of working beyond, below, and above existing pathways for change — building towards a new mentality for a world ahead of the barbarism of hyper individualism, possessiveness, competitiveness, and the identitarian reification of the like, in order to mitigate the continual possibility that things will not turn out well. To paraphrase what Horkheimer wrote to Adorno in 1956, I do not believe that things will turn out well, but the possibility—and indeed necessity — that they might is of utmost importance. ${ }^{120}$

Why abandon the emancipatory potential of cosmopolitanism, when just like Marxism, it has failed because it has never truly seen the light of day in its best, most honest form? We are beyond a time where half-measures are more practical than failed wholemeasures. We need solidaristic movements that draw on the most likely solutions that can still be considered solutions in a world that seems to have exenterated our world and especially our imaginations of all solutions. This is what class struggle means today.

For Fromm the transition to a truly sane society, a humanized, emancipated society demanded four conditions, and none of them are guaranteed - in fact, quite the opposite:

\footnotetext{
${ }^{120}$ The actual line is "I do not believe that things will turn out well, but the idea that they might is of decisive importance" $(2011,45)$.
} 
1. We are suffering and are aware that we are.

2. We recognize the origin of our ill-being.

3. We recognize that there is a way of overcoming our ill-being.

4. We accept that in order to overcome our ill-being we must follow certain norms for living and change our present practice of life. (Fromm 1976, 168)

A postcapitalistic cosmopolitan mentality must be forcefully conceptualized. It must be shown to continue to exist, however latently or sporadically in the here-and-now. It must be cultivated and spread. It must be struggled for. It is a practically-oriented aspiration, and a crucially important one. To abandon the possibility of this alternative is to surrender to the idea that this harmful, alienating, exploitative socioeconomic system, and the politics it breeds, is truly the best we as humans can do. This surrender is the last nail in the coffin that the capitalistic mentality supplies for the funeral of progress and justice. This nail is the final nail in the coffin of everything that cosmopolitanism does and should stand for. It is a nail that has been lingering, waiting for its moment of ignominious glory. We - as cosmopolitan theorists - may have forgotten it was there waiting, but it seems that those who own the hammer factories never did.

The theoretical resolution of the contradictions of cosmopolitanism is incomplete so long as the practitioners and representatives of cosmopolitanism, both as an academic theoretical tradition primarily in international relations, the agents of transnational IGOS, NGOS, and social movements who struggle within the current human rights regime fail to self-reflect on their social positions, practices, and mentalities in regard to capitalism. The power of the inclusion of the capitalistic mentality into all forms of cosmopolitan thought is self-destructive. Through critical, dialectical self-reflection cosmopolitans must take the first step to think, act, and be differently. A productive engagement with contemporary 
Marxism, highlighting the radical potential of the important practical and normative similarities is the crucial first step.

The path forward is certainly not an easy one, nor is it one that is likely to succeed in the current moment, but it is the only viable path forward — a path that engages with many avenues and detours, all aimed towards postcapitalism. The Conclusion of this project explores precisely the above-mentioned conditions in the context of the preceding reconstruction of a neo-cosmopolitan Marxism. 


\section{CONCLUSION \\ Towards a Postcapitalistic Mentality}

\section{Overview}

Cosmopolitanism, in its normative versions, represents a vision for a better world, a more just, inclusive, global political, economic, social, and cultural vision. The imperialistic perversions aside, as James Ingram and Pheng Cheah both agree, this vision is best captured in the still-problematic but potentially fruitful international human rights regime. As Beck and Beardsworth agree, a realistic cosmopolitanism cannot eschew the role of the nation-state in this process at this point in time. Perhaps in the future, nationstates (however reconceived and reorganized they may end up) may not play a significant role; they may not even exist (and certainly shouldn't in their current iterations), but for the time being, they remain an important locus for political power, however distorted and corrupt that power is. What this project has aimed to do, is show how one of the undertheorized and underdeveloped aspects of global capitalism, the "capitalistic mentality" (that psycho-social mechanism rooted in the material relations of capitalist systems that mediates the norms, beliefs, and behaviors of those ensconced in this system as subject-objects, however non-identical they are) contradict the progressive aims of the cosmopolitan tradition primarily in theory, but also in important practical ways. The solution offered in chapter four, through an engagement and further critique of the neo/post-Marxist traditions, is that cosmopolitanism needs to embrace a radically-reformist postcapitalist normative horizon oriented around a critique of the material and ideological dimensions of the capitalistic mentality detailed in chapter two. This radical reformist horizon - built on the radical humanistic social psychoanalysis and the ensuing political arguments of Erich Fromm as well as the negative dialectics of Theodor Adorno and his 
critique of reified identitarian thinking and the various dimensions of the totalizing effects represented in his analysis of the culture industry — must be one that reorients cosmopolitan ethics against the exploitative and practically destructive consequences of globalized capitalism in favor of a solidaristic mass democratic egalitarianism. The reformist element of this argument is based on the problematic dominance of the capitalistic mentality with respect to undermining democratic solidarities and cooperative endeavors against capitalism to such a degree that rapid, intentional changes just simply do not appear to be feasible, especially given the fact that despite increased proletarianization of global populations and increases in the rate of exploitation labor movement that are emerging are often fighting for important but in the larger context meager reforms within the capitalist system (Jonna and Foster 2016; Frase 2016). This is not to denigrate those movements. In fact, these movements likely will be an important dimension of the basis for the kind of radically-reformist postcapitalist cosmopolitanism detailed here, but they to a certain degree, as discussed in chapter four, do not represent a fundamental rejection of the fundamentals of the capitalist system (as with the cosmopolitans detailed here, perhaps with the exception of Cheah, they remain concerned with mitigating the worst excesses and injustices of the capitalist system without a coherent strategy for moving beyond capitalism) (MacKlean 2008; Scipes 2016). This radical reformism is also reformist in that it does not reject the potential for a democratization of the existing (and honestly, still very young) global governance regimes, however rooted in and reproductive of the global capitalist system at the current conjuncture.

What has remained undertheorized up to this point is what exactly is meant by postcapitalism. In some instances I have suggested that the normatively desirable 
instantiation of postcapitalism, the version of postcapitalism that would most successfully address the contradictions within the cosmopolitan conception of progress towards global justice, must be a kind of democratic socialism. Postcapitalism is a broader term, and I use it intentionally where I use it. While it seems to be that the only alternatives that have yet been theorized as alternatives to capitalism - that are improvements on and beyond capitalism, because we of course have plenty of worse alternatives in the dustbin of human civilization — are kinds of socialism (including variant of anarchism not addressed in this project given their overall lack of systematicity—-though Hardt and Negri's work draws on an interesting mix of Marxism, post-Marxism, and the anarchist inspired Italian autonomists). Socialism is however still a dirty word, the relative successes and popularity of previously mentioned figures and groups like Bernie Sanders, Jeremy Corbyn, Pablo Igleisas and Podemos, and Alexis Tsirpras' SYRIZA party in Greece notwithstanding. I want to be candid here. While I certainly think that socialism, in its best Marxist variants (like the one implicit in Srnicek and Williams' neo-accelerationism), to represent the best framework for conceptualizing postcapitalism, perhaps there are others that deviate significantly enough to refuse categorization within this tradition that are worth considering. The specific version of postcapitalism that is pursued is very important, but should be left to a properly educated and critically reflective global population to determine. Regardless, the core of my argument in this project is that at the very least, a certain postcapitalist vision is desperately needed to mollify the self-destructive contradictions within cosmopolitanism, and that postcapitalist vision needs to meet certain criteria in order to successfully address those contradictions. 
Not every reform, for it to be acceptable, needs to be a socialist reform. The key to whether a reform is appropriately radical — that is, whether it aims at addressing the contradictions between capitalism and global justice as broadly conceived within the cosmopolitan tradition-is whether it is aimed at moving beyond capitalism, whether it is to the benefit of most people in the world (the globally least advantaged to borrow the neoRawlsian terminology), and whether they are (likely to be) effective towards these ends. Radical reforms need not be perfect. How could we expect them to be? We are wading into oft-theorized, rarely travelled, and certainly uncharted territories. There will be set backs. There will be outright failures. The two keys are patient, collaboratively self-reflective adjustment and solidaristic commitment.

This postcapitalist vision that reorients global ethics and cosmopolitan more specifically against the exploitative, commodified, injustice-reproducing system demands not just an alternative system, but an alternative mentality. While it seems rather obvious that as a distinct mode of production, postcapitalism or socialism would (re)produce, normalize, and justify a different mentality than that of capitalism, if that mentality were better suited to the needs and genuine humane desires of most people around the world, this hardly seems like a negative. In other words, just as all hegemonies are not bad, not all ideologies, not all mentalities that we could be conditioned into reinforce injustices. However, we are not living under a postcapitalist or socialist global system. Therefore, in properly dialectical fashion, there needs to be a transitional mentality that emerges from within the stage of late capitalism that opens up the process of mass social transformation on a psycho-social register. This is what, in connection with Stephen Eric Bronner's "cosmopolitan sensibility," will be called the "post-capitalistic mentality." 
Throughout this project I have decided to neither specifically define postcapitalism nor hide the truth that postcapitalism, as stated above, in order to resolve the contradictions within the cosmopolitan tradition, must indeed be kind of (democratic) socialism. I have done this to both make this latter point as clearly as possible while also avoiding reifying an identitarian conception of socialism that would undermine the necessary diversity this future world should be approached with at this point in history. As discussed briefly in the previous chapter, there are indeed specific proposals and practices that have been developed over the past decades and even centuries that we can build on here to think about what a negative dialectical conception of cosmopolitan socialism or postcapitalist cosmopolitanism would mean, without reifying one particular vision. While a negative dialectical conception of this improved understanding of a radically realistic postcapitalist cosmopolitanism must be necessarily open and self-critical, there are a limited number of alternatives, of the many alternatives that are possible futures, which would actually address the concerns explored in this project in a positive way, a way that resolves the selfdefeating relationship the cosmopolitan tradition holds with capitalism, specifically related to the capitalistic mentality.

\section{Postcapitalistic Mentality}

Both Fromm and Adorno suggest that there are alternative ways of thinking and being that are potentially incompatible with capitalism and thus serve a radical or revolutionary purpose. For Adorno, this means non-identitarian thinking. For Fromm, this means productive character orientations and social character accomplished through his thoroughly dialectical concept of radical reform (and these are alternative ideas that emerged out of a profound sense of dissatisfaction with both capitalism and the capitalistic 
mentality, which, however totalizing, given its pervasive contradictions of its own premises and promises, can never prevent resistances from emerging, at least not comprehensively up to this point, though it has gotten disturbingly close (Harvey 2014). This project has shown how cosmopolitanism is undermined by its - often unacknowledged - complicity with global capitalism, which always includes a normalized psycho-social dimension which serves to maintain the current system. In the case of capitalism, this psycho-social dimension consists of the identitarian impulses and hyper-individualistic possessive competitiveness of the capitalistic mentality.

Cosmopolitanism needs to cultivate-beginning with its own theoretical demands - the radical potential for a new kind of subject, a post-capitalistic subjectivitythe potential of a new human, the kind of person needed for a new kind of world. This may seem like an unattainable goal, and its difficultly and improbability of success should not be confused with impossibility. Here is the good news: we all likely have the potential to be this kind of person needed for a world the necessary world ahead—at least one that is not a dystopian nightmare. Both Fromm and Adorno in various ways offer us the solutions to the problems they specified. ${ }^{121}$ Fromm tells us that we do have this potential inside of us; it is just a matter of altering our social conditions through solidaristic resistance to the existing marketing social character. Deep down we want to labor, and labor creativity and spontaneously. We want to love one another, or rather we feel emptier, less fulfilled when we are not truly connected to others in non-commodified, non-marketized ways. Adorno's response is: I agree that capitalism certainly tends to devour this productive alternative, but

\footnotetext{
${ }^{121}$ In due fairness to both thinkers, what follows is an Adornoian negative dialectical re-interpretation of Fromm's argument on this point. The importance of this is great, but the deviation from Fromm's pure argument could not be slighter. Fromm is more positive than Adorno.
} 
it is possible that we might still be able to be different. Adorno is pervasively negative in the philosophical sense (not to be conflated with misanthropic or pervasively pessimistic). He speaks about potential possibility or possible potentiality, never about a sure potential or a sure possibility. When we take the still-reified confidence out of Fromm's argument it becomes a very specific speculation about the radical possibility that could be unleashed in resistance to and beyond the capitalistic mentality.

In Adorno's work, we find the conception of a new kind of person (though Adorno would loathe this humanistic language), a non-identitarian thinker, a person who is capable of seeing the otherwise reified social relations they inhabit and is capable of seeing or experiencing (or at least attempts to see or experience) the non-identity of the commodity society that stems from the base of capitalism. Adorno refers to this experience of the nonconceptuality of concepts, of the non-identity of realities as genuine philosophical experience, and it is literally a utopia $(1973 ; 2008)$. This is especially true under capitalism, after all people would want to buy or sell such an experience if they could (or simply sell books that talk about it). It is a goal of thinking that may never be met, and if it is it may never be provable. Adorno says with negative dialectics we are trying to do something with language that language probably cannot do. Here, we are trying to do something with society that it very well might not be able to do (1973). The possibility for emancipation is worth the chance.

In Fromm's work, we find the alternative speculative anthropology in three concepts: biophilia, the productive social character, and the being mode of existence (which all relate to one another). First, the productive social character (or the social generalization of the productive character orientation) is the inverse of the many non- 
productive character orientations, of which the marketing character is the most important in the twentieth and now twenty-first century. The core elements of the productive social character are: cooperation (as opposed to competitiveness or apathy), sharing (as opposed to hoarding or destroying), and spontaneous creativity (as opposed to regimented production or mindless consumption) (Fromm 1990, 82-111). The goal for Fromm is to find the opportunities to develop these traits within whatever society one finds oneself and build on them, to spread them, to normalize these characteristics against the characteristics of the capitalistic mentality (Fromm 1955).

Second, biophilia is the inverse and negation of necrophilia (Fromm's alteration to Freud's death drive). Biophilia is literally the love of life and life-forms (Fromm 1992, 375-407). For Fromm, the biophilic person has a generally loving attitude toward the world and values people primarily as ends in themselves, not as means. The biophilic person appreciates objects with a lived-history, things with a human, imperfect element. The biophilic person opposes the sterility and blandness of the commodity form. The biophilic person see the incompleteness of reality and attempts to see the creativity of others for what it is and not how it can serve them or for what gadget it can produce (Fromm 1971, 35-57, 142-144).

Most closely related to biophilia is the "being" mode of existence, which is the inverse of the possessive, competitive, "having" mode of existence. The having mode of existence recalls associating existential fulfillment with the possession of things, commodities, people (as friends, lovers, employees, or political subjects) and even experiences (e.g., dates or vacations). The being mode places the value of existence in the journey of life itself, in the experiences we share with one another that help us all grow as 
human beings towards a fuller potential (Fromm 1976). There is no place for markets or salability here, only solidarity and love. Many of these traits that comprise biophilia and the being mode of existence.

What then would this possible potentiality of humanity consist of? It would certainly include a kind of biophilia, a life oriented towards being, cooperation, sharing, loving, non-identitarian thinking, critical reason and a true knowledge of our social relations. This is a socialist or post-capitalistic mentality, and it is the mentality that is required for a more comprehensive and practicable cosmopolitanism.

The closest conception of this new mentality is found in Stephen Eric Bronner's (2006) conception of the cosmopolitan sensibility, though the post-capitalist cosmopolitan mentality based on Adorno and Fromm here is a bit more radical than Bronner's conceptualization. Though Bronner's work is not generally engaged in the disciplinary debates around cosmopolitanism, his choice of the term "cosmopolitan" is telling and noteworthy for two keys reasons. Not only does it refer to a more solidaristic disposition like the one I have been describing, but it is also explicitly juxtaposed to liberal capitalist sensibilities. According to Bronner, "Human rights is useful only from the standpoint of critique and resistance. It projects a form of solidarity that is more than legal and extends beyond the limits of class, race, and nation....Human rights is predicated on an existential willingness to feel empathy and compassion for the victim, the oppressed, and the disenfranchised" (145-146).

The cosmopolitan sensibility is the willingness and cultivated ability to feel this transnational empathy and compassion for others, building towards any number of solidarity projects that form the basis of truly cosmopolitan social, political, and economic 
movements. It is a sensibility that must resist commodification (Bronner 2006, 147-149). It is a sensibility that must be able literally to teach others and to bring diverse peoples and groups together to resist the basic elements of capitalism and especially the most egregious consequences of global free market capitalism (157-158). "The old is dying and the new is not yet born" is the slogan of the cosmopolitan sensibility, but the rest of Bronner's argument suggests that this sensibility, though it may not be born yet on a mass scale, our societies are pregnant and the sensibility is in its fetal stage. The question is will it come to term or not (150). For our purposes here, it is entirely consistent with Bronner's argument to say that the post-capitalist cosmopolitan mentality fills the ideal of a cosmopolitan sensibility with a bit more content, but the goal is largely the same: to criticize the ways of thinking that maintain various forms of oppression and undermine progress towards justice.

One of the key aspects of the capitalistic mentality is the hyper-individuation that people perceive and experience. Both Fromm and Adorno criticize the destruction of the individual through that very concept taken to its extreme, ironically under conditions of mass culture. The belief in the pure individual is more of a self-fulfilling prophesy than it is preexisting fact that neoliberal capitalist ideology merely emphasizes. Capitalist ideology and its psychological manifestation in the capitalistic mentality produces, normalizes, and spreads the precise beliefs and naturalized behaviors that it claims are ahistorical. These assumptions, though to lessening degrees as we get closer to the radical cosmopolitans, are pervasive throughout the cosmopolitan literature. It is not until we get into the post-Marxist global theories of Etienne Balibar, and even more so with Hardt and Negri, that we more fully appreciate the produced false totality of individual identity under late capitalism. We are not nearly as complete as individuals when we believe and act as 
though we are an unencumbered, detached, isolated subject with near-absolute agency. The ideal form of individuality that would form the core of the post-capitalistic mentality would be what Balibar calls (based on his reading of Rousseau and Marx) "transindividuality." Transindividuality is the honest intersection of a single human being with the society and social conditions they are raised and live under. It is the complex co-construction of community and individual in relation one another (Balibar 2014, 96, 102-103; Read 2015).

Though Fromm does not use the term, the idea of transindividuality is central to his alternative productive social character. Transindividuality is the de-reification of true human individuality, which is always co-constituted in relation to others. It is the nonidentitarian instantiation of individuality. It is a dialectical concept that, while it has a definition, is inherently fluid, just as is our understanding of our own actual individuality is in relation to the groups, communities, and systems we are a part of. We can see how it is influenced and conditioned by our interactions without being able to say precisely to what degree or in what ways in every instance.

While Marx was correct that life determines consciousness, that our psychologies are conditioned by our social environment and experiences, those produced psychologies - the mentality —aids in the reproduction of those social conditions (The German Ideology, 154-155). If all the institutions and laws that support capitalism ended tomorrow, some version of capitalism or something worse would likely spring up in its place, or so I will be arguing in the next chapter more forcefully. We are all capitalistic beings now in some way or another. Some of us represent the capitalistic mentality more comprehensively that others. Some of us advocate its desirability more than others, and some of us accept it more readily than others. The point is that we all embody it to some 
degree whether we want to or not. It is a part of who we become being raised under capitalist relations of production and the culture and politics that derive from them. If capitalism ended tomorrow, we would still be left with a world of largely capitalistic people.

Psychology changes more slowly than society or politics in most cases. Simply put, we need to become different people with different mentalities over time if we are to achieve the various goals of cosmopolitanism. This is the primary function of the "class" struggle described in chapter four. Class struggle that exceeds class-reductionism can serves as a social and political learning process for people to become different than capitalism has conditioned them to be. Class struggle functions as a mechanism for resocialization, a kind of resocializing role that postcapitalist parenting and postcapitalist education would need to take for the next and future generations. This process of resocialization through democratic class struggle, over time, can create reformed familial, cultural, and educational systems that will (re)produced these postcapitalistic people from early childhood. ${ }^{122}$

Also, more realistically, because the predominance of the capitalistic mentality (its normalizing component being most important in this instance), it is extremely unlikely that capitalism is going anywhere fast - at least not anywhere we want to go. Therefore, proposals that suggest immediately dismantling capitalism are not going to be very successful. Beardsworth (2011) is correct that cosmopolitanism requires political leadership and judgment; he simply does not take that need far enough. We need democratically-responsive and accountable radical political leaders with anti-capitalist rhetoric, arguments, and progressive policy alternatives to begin de-normalizing the

\footnotetext{
${ }^{122}$ One example of how this could work is described by Megan Erikson in her 2016 book Class War: The Privatization of Childhood.
} 
capitalistic mentality and its political and institutional manifestations in the UN and IMF and the like.

We need a new praxis, a radical negative dialectical praxis that engages head-on with the existing realities. As Beardsworth has argued most persuasively, we cannot simply wish away the state system - and I believe we both agree this applies to capitalism as well. Despite our real disagreements regarding the potential for humanizing capitalism, capitalism must be the starting point and in the context of a ever-evolving and deterritorizalizing state-system rooted in an increasing problematic archaic understanding of sovereignty that as he and others like Held and Pogge have shown simply does not work in a world so directly influenced by transnational processes like climate change, pollution, potable water access, and the global financial system that undergirds it all.

As I have shown in chapters two and three, however, the capitalistic mentality makes it increasingly unlikely that capitalism will be reformed enough (assuming that is economically possible - a point that many Marxists vehemently contest if not outrightly reject) to make a serious dent in mitigating climate change, alleviating global poverty, and decreasing other human rights violations (of which the exploitative wage labor of the capitalist system could itself be considered an example, though that brings us back to the problematique addressed in chapter one regarding the capitalistic assumptions which interpenetrate conceptions of human rights and global justice).

Why now though? Why can we not give capitalistically-inclined cosmopolitans more time to figure out if capitalism can be more aggressively reformed under their program? What is the necessity for this postcapitalist ethics now? Absolute poverty has improved, that is true, but at what cost? Is the word significantly more democratic? Less 
violent? Hardly_not when we consider the persistent of structural violences and the overall rate of exploitation (Leech 2012). These should be motivation enough, but apparently they are not. The twenty-first century presents human civilization with a new existential threat qualitatively distinct from the existential threat posed by the twentieth century. We have moved from an epoch that was, at least for the second half of the century, defined by the fear that a single person's choice could lead to the destruction of the entire planet — which of course would include humanity and all or most living things as well. I am speaking of course about nuclear weapons. We still face the threat of an individual being able to start a global nuclear war whose results can hardly be imagined - though many great writers and filmmakers have done an exceptional job trying. We face a new threat. A threat that is caused by systemic logic and the behavior of a large percentage of the global population (though it certainly hasn't been that way for most of the history of industrialization). Due to global climate change, we face the very real threat of the Earth ceasing to be habitable for our youngest and future generations. While we may be under the new geological timeframe of the Anthropocene, it is more accurately described as the "capitalocene" - an era where capitalism has altered the actual functions of the planet's diverse interactive ecosystems not in the interests or due to the actions of all or even most people, but instead of a very small subset of the global population, namely the ruling capitalist elites and their collaborators. It is an era that all of our best, most respected scholars seem to be telling us has warmed-out its welcome (Moore 2016).

I do not know that it would be appropriate to call this good news, but the destruction of the Earth is itself tied into the same systemic logic and practices of capitalism that produce the capitalistic mentality and debilitate cosmopolitan progress, as discussed in 
chapter three, and therefore the solution on offer here for a postcapitalist cosmopolitanism is the only cosmopolitanism that meets the necessity of preserving the habitability of planet Earth. (Foster 2011; Klein 2014; Lowy 2015; Moore 2015). A postcapitalist cosmopolitan vision, put into practice, can kill many birds with many interconnected stones. While Marxists are often depicted (and too often rightly depicted) as offering simplistic solutions, simply putting all the workers currently employed on the planet in charge of their workplaces would not solve racism, sexism, and ecological destruction. While this is slightly more of a delusion than it is a caricature (though it is both), it is quite possible that postcapitalism, including democratized workplaces, households, and communities, offers the best hope to resolve all of these other aspects of injustice in our contemporary world.

The call—and need (at least within the cosmopolitan and Marxist traditions)—for this new sensibility, this new mentality, cannot happen overnight. As scholars and activists, we can see the need for this mentality, but recognizing its importance is not enough. It will take time, time we probably don't have when we consider the depth and seriousness of the threats posed by the ecological destruction of the planet particularly with regard to climate change, and the always-present threat of nuclear war. It is our role, as scholars, citizens, and inhabitants of this planet to both model these character traits, and much more importantly, to speak out for their necessity, to advocate specific policies (like a fully green grid or the UBI discussed earlier), determined ideally by the people who will be most affected by the action (or inaction), policies that move our global system away from one rooted in mass commodification and mass alienation, away from the structures, norms, behaviors, and beliefs that comprise and (re)produce the capitalistic mentality. The ethical framework sketched above is just the first step in this process, and it really is not the first 
step of its kind. Leftists for generations have, in various ways, made similar attempts, but for an even greater diversity of reasons have failed to produce any system-wide, global changes in the direction we seek-we need-to move in. This work is a continuation of their past efforts, and I—we — can only hope it is even somewhat more successful. Climate change and mass extinction have put a clock on this project (Kolbert 2015). The longer this process takes, the more difficult this process will be. There are openings, opportunities, and chances. We must embrace them and celebrate the small victories, while never getting too hopeless when facing any likely roadblocks, let-downs, or genuine failures. While postcapitalism can take many forms, and the process towards achieving a world ahead of capitalism need not follow any of these models perfectly or even remotely, there are certain principles that must guide that process and that world ahead. Some may take different forms or be altered in some ways, but in order for what comes next to be worth looking forward to, we must make sure that we make it that way together.

Before concluding, I want to leave you with an allegory for the task ahead of all of us who are concerned with a radically progressive global justice, who want an egalitarian world ahead of our own. This allegory is designed to help readers imagine better just how psychologically and therefore practically difficult the project laid out here is. It is not one without hope - though it is indeed one without optimism. Here's why:

Imagine a large family living in a very old house. This house was built on an island long ago by ancestors. The house is passed on from generation to generation. The family survives by growing fruits and vegetables in a greenhouse and fishing off the coast. They have no access to the outside world. Over the course of a few years, a couple of the younger family members start to recognize that the house is beginning to weaken structurally - that 
eventually the house will collapse, perhaps not all at once, but over time it will become increasingly uninhabitable for a variety of reasons. These younger family members attempt to convince the others including their most respected elders that the house will not remain unless structural enhancements are made to the dwelling. The elders reject their claims as alarmist and disrespectful of the gift this house represents from their ancestors. The younger family members decide that if they came up with an actionable plan to alter the structure of the house, using most of the existing materials in new ways, the house will likely last for at last several more generations and their elders would see the seriousness of their claims. Again, they are ignored. "We simply cannot rebuild this house while we are living in it, and even if we could it would still represent a rejection of everything we know about our lives. This house is everything to us, and to alter it would amount to a rejection of that identity."

This is the struggle we are up against. For most people, the belief in capitalism is like this family's belief in the importance of the house. Not only are we up against the very real difficulty of building our world anew with the existing materials we have, but we have to do it with everyone still inside of it and with their support and cooperation. It is this last dimension that the problem of the capitalistic mentality aims to highlight in the context of cosmopolitan claims for global justice.

\section{"Final" Thoughts}


This project is a work of politicized political theory; I make no claims to neutrality or objectivity. ${ }^{123}$ The time for those measures has passed. We need to be more aggressive in our work, inside and beyond the academy. This project has shown that there are important elements within the cosmopolitan tradition that are worth maintaining, and there are some crucial aspects that need to be reworked, and, when it comes to capitalism and the capitalistic mentality, some things that need to be purged entirely. This project has shown the value of negative dialectics, that Adornoian approach to reading, thinking, and critique, which offers an opening to more deeply understand the contradictions presents in our studies, our scholarship, and our everyday lives, and that opening has the potential to produce greater political openings for those who are interested in a genuinely progressive politics that moves us beyond the inegalitarian, unjust, exploitative confines of all varieties of academic and corporate liberalism and all forms of capitalism. These contradictions will not simply disappear on their own. They must be challenged. The challenge offered here, through my negative-dialectical reading of the cosmopolitan tradition, combined with the social-psychological critical theory of Erich Fromm, is that global justice must be pursued with a post-capitalist sensibility, a post-capitalist cosmopolitan mentality that refuses to accept the status-quo of capitalism by more comprehensively appreciating what capitalism really means and why, while it is co-constitutive with cosmopolitanism, is it also

\footnotetext{
${ }^{123}$ With that said, Adorno's conception of objectivity described in Negative Dialectics and Minima Moralia emphasized the need to include a radicalized conception of subjectivity to regain a fuller sense of objectivity - after all subjective responses are produced as a result of interactions with objects (and subjects themselves are also objects). In this deeper, more comprehensive sense, this project is aiming at objectivity. Additionally, if one looks at those texts that are typically included in undergraduate and graduate course reading lists like Hobbes' Leviathan, Locke's Two Treatises of Government, Rousseau's Social Contract, much of Marx's work, up through the work of contemporary theorists such as Sheldon Wolin, Judith Butler, and William Connolly, much of these works are overtly political in the sense that they were intended to intervene into a broadly socio-political conversation (in addition to being intellectual/academic contributions), aiming to articulate a certain political vision or perspective and indeed influence the politics of the day and of the future. It is in this sense that this project here is "politicized political theory."
} 
incompatible with capitalism. As I argue in chapter four, this line of thinking can lead us to see opportunities in the contemporary neo-/post-Marxist tradition. Once a deeper appreciation for the repressive and productive (here in the bio-political sense developed by Foucault and later by Hardt and Negri) power of the capitalistic mentality is factored into their arguments, the conclusion reached (of which this is only one potential possibility), is that a return to Fromm's notion of radical reform tied to Luxemburg's concept of unlimited democracy is what we need - a rereading of the dictatorship of the proletariat that is neither a dictatorship nor entirely occupied by the proletariat.

However definitively-phrased many of the claims made here are, they, in properly negative dialectical fashion should not be understood are perfect or interpreted as attempting to be the final words in this discussion. On the contrary, this project, is meant to shift the conversation in a new direction, to bring cosmopolitans and all stripes of contemporary Leftists in the Marxist tradition together in a productive dialogue-a dialogue we are responsible for, together. This is only meant as a new beginning towards a more collaborative conversation that aims to produces new practices, new norms, and new beliefs against the injustices that permeate our worlds, towards a conversation and praxis that is truly worlds ahead. To borrow from István Mészáros (2015), in his alteration of Engels' and Luxemburg's famous quip, we will have either socialism or barbarismand maybe not even barbarism. What we get will not be determined by us alone, history has done much work against us, and it will continue to, but it will be through collective effort and determination that will win the future, this reimagined— just, egalitarian—world ahead, if anything at all will. 


\section{BIBLIOGRAPHY}

Achcar, Gilbert. 2013. Marxism, Orientalism, Cosmopolitanism. Chicago, IL: Haymarket Books.

Adorno, Theodor. 2005 [German 1951]. Minima Moralia: Reflections from Damaged Life. Trans. E.F.N. Jephcott. New York, NY: Verso.

-- 1973 [German 1966]. Negative Dialectics. Trans. E. B. Ashton. New York, NY: Continuum.

--1993 [German 1963]. Hegel: Three Studies. Trans. Shierry Weber Nicholsen. Cambridge, MA: The MIT Press.

--2003 [German 1964-1965]. Lectures on Negative Dialectics: Fragments of a Lecture Course. Trans. Rodney Livingstone. Ed. Rolf Tiedemann. Malden, MA: Polity Press.

--1986 [1980]. Aesthetic Theory. ed. Gretel Adorno and Rolf Tiedeman. Trans. by Robert Hullot-Kentor. Minneapolis, MN: University of Minnesota Press.

--2002. "On the Fetish-Character in Music and the Regression of Listening" in Essays on Music trans. Susan H. Gillespie, ed. Richard Leppert. pg. 288-317.

Althusser, Louis. 1971. Lenin and Philosophy and Other Essays. Trans. Ben Brewster. New York: Monthly Review Press.

Althusser, Louis and Balibar, Etienne et. al. 2016. Reading Capital: The Complete Edition. Trans. Ben Brewster and David Fernbach. New York: Verso.

Amin, Samir. 2004. The Liberal Virus: Permanent War and the Americanization of the World. New York: Monthly Review Press.

Archibugi, Danielle. 1995. Cosmopolitan Democracy: An Agenda for A New World Order. Cambridge: Polity.

--1998. Re-Imagining Political Community: Studies in Cosmopolitan Democracy. Stanford: Stanford University Press.

-- 2003. Debating Cosmopolitics. New York: Verso.

Arendt, Hannah. [1948] 1979. The Origins of Totalitarianism. Orlando, FL.: Harcourt. --[1954] 2006. “What is Freedom?” in Between Past and Future: Eight Exercises in Political Thought. New York: Penguin. 
Arriighi, Giovanni. 2010. The Long Twentieth Century: Money, Power, and the Origins of our Times. New York: Verso.

Balakrishnan, Gopal (ed.). 2003. Debating Empire. New York: Verso.

Balibar, Etienne. [1976] 1977. On the Dictatorship of the Proletariat. Trans. Grahame Lock. London: New Left Books.

--2014. Equaliberty: Political Essays. Trans. James Ingram. Durham, NC: Duke University Press.

Barber, Benjamin. 1984. Strong Democracy: Participatory Politics for a New Age. Los Angeles, CA: University of California Press.

-- 1996. Jihad vs. McWorld: Terrorism's Challenge to Democracy. Toronto, Canada: Random House.

--2008. Consumed: How Markets Corrupt Children, Infantilize Adults, and Swallow Citizens Whole. New York: W.W. Norton.

Beardsworth, Richard. 2011. Cosmopolitanism and International Relations Theory. Malden, MA.: Polity Press.

Beck, Ulrich. 2006. The Cosmopolitan Vision. Trans. Ciarin Cronin. Malden, MA: Polity.

Beder, Shannon. 2002. "Putting the Boot In" in The Ecologist 32(3), April 2002.

Beitz, Charles. 1999. Political Theory and International Relations. Princeton, NJ. Princeton University Press.

Bell, Daniel. 1976. The Cultural Contradictions of Capitalism. New York: Basic Books.

Benhabib, Seyla. 1987. "The Generalized and the Concrete Other: The Kohlberg-Gilligan Controversy and Feminist Theory" in Feminism as Critique: Essays on the Politics of Gender in Late-Capitalist Society. ed. S. Benhabib and D. Cornell. Malden, MA: Polity.

--1990. "Afterword: Communicative Ethics and Current Controversies in Practical Philosophy." In The Communicative Ethics Controversy eds. Seyla Benhabib and Fred Dallmayr. Cambridge, MA: MIT Press.

--1993. Situating the Self: Gender, Community and Postmodernism in Contemporary Ethics. Cambridge, MA: Polity Press.

--2004. The Rights of Others: Aliens, Residents, and Citizens. Cambridge, UK.: Cambridge University Press. 
--2006. Another Cosmopolitanism. Oxford, UK.: Oxford University Press.

--2011. Dignity in Adversity: Human Rights in Troubled Times. Malden, MA.: Polity Press

Bijleveld, Erik and Aarts, Henk. 2014. The Psychological Science of Money. New York: Springer.

Bronner, Stephen Eric. 2004. Reclaiming the Enlightenment: Towards a Politics of Radical Engagement. New York: Columbia University Press.

Brown, Chris. 1992. International Relations Theory: New Normative Approaches. New York: Columbia University Press.

Buck-Morss, Susan. 1977. The Origin of Negative Dialectics: Theodor W. Adorno, Walter Benjamin, and the Frankfurt Institute. New York, NY: The Free Press.

Calhoun, Craig. 2003. "The Class Consciousness of Frequent Travellers: Towards a Critique of Actually Existing Cosmopolitanism," in Debating Cosmopolitics. Ed. Daniele Archibugi. London, UK:Verso.

Cheah, Pheng. 2006. Inhuman Conditions: On Cosmopolitanism and Human Rights. Cambridge, MA: Harvard University Press.

-- 2006. "Cosmopolitanism" in Theory, Culture, and Society. Vol. 23, no. 2-3, Pg 486-496. Sage.

Chomsky, Noam. 2013. On Anarchism. New York: The New Press.

Chua, Amy. 2003. World on Fire: How Exporting Free Market Democracy Breeds Ethnic Hatred and Global Instability. Toronto, Canada: Random House.

Cohen, G.A. 2009. Why Not Socialism?. Princeton, NJ: Princeton University Press.

Crary, Jonathan. 2014. 24/7: Late Capitalism and the End of Sleep. New York: Verso.

Cremin, Colin. 2015. Totalled: Salvaging the Future from the Wreckage of Capitalism. London: Pluto Press.

Davies, William. 2015. The Happiness Industry: How the Government and Big Business Sold us Well-Being. New York: Verso.

Drakulic, Slavenka. 1999. Café Europa: Life After Communism. New York: Penguin. 
Draper, Hal. 1962. "Marx and the Dictatorship of the Proletariat" in New Politics. Vol. 1 No. 4.

Eagleton, Terry. 2011. Why Marx Was Right. New Haven, CT: Yale University Press. --2015. Hope Without Optimism. New Haven, CT: Yale University Press.

Fields, Karen E. and Fields, Barbara J. 2012. Racecraft: The Soul of Inequality in American Life. New York: Verso.

Forbes, Steve and Ames, Elizabeth. How Capitalism will Save Us: Why Free People and Free Markets Are the Best Answer in Today's Economy. New York: Crown Business.

Foster, John Bellamy et. al. 2011. The Ecological Rift: Capitalism's War on the Earth. New York: Monthly Review Press.

Frase, Peter. 2016. Four Futures: Life After Capitalism. New York: Verso.

Fromm, Erich. 1990 [1955]. The Sane Society. New York: Holt.

--1994 [1941]. Escape from Freedom. New York: Holt.

--1961. Marx’s Concept of Man. Open source: Accessed online at Marxists.org.

--1962. Beyond the Chains of Illusion: My Encounter with Marx and Freud. New York: Simon and Schuster.

--1968. The Revolution of Hope: Toward a Humanized Technology. New York: Bantam.

--1976. To Have or To Be? World Perspectives series. New York: Harper \& Row. --[1960] 2010. "Let Man Prevail” in On Civil Disobedience: Why Freedom Means Saying 'No' to Power. First Harper Perennial Modern Thought edition. New York: HarperCollins.

Fukayama, Francis. 1992. The End of History and the Last Man. New York: Free Press.

Furnham, Adrian. 2014. The New Psychology of Money. New York: Routledge.

Furnham, Adrian and Argyle, Michael. 1998. The Psychology of Money. New York: Routledge.

Gibson-Graham, J.K.; Resnick, Stephen; Wolff, Richard. 2001. Re/Presenting Class: Essays in Postmodern Marxism. Duke University Press: Durham, NC. 
Gibson-Graham, J.K. [1996] 2006. The End of Capitalism (as We Knew It): A Feminist Critique of Political Economy. University of Minnesota Press.

--2006. A Postcapitalist Politics. University of Minnesota Press.

Giddens, Anthony. 2010 [1971]. Capitalism and Modern Social Theory: An analysis of the writings of Marx, Durkheim and Weber. Cambridge University Press.

Gilligan, Carol. 1982. In A Different Voice: Psychological Theory and Women's Development. Cambridge, MA: Harvard University Press.

Glassman, Ronald. 2000. Caring Capitalism: A New Middle-Class Base for the Welfare State. New York: St. Martins.

Gluckstein, Donny. 2011. The Paris Commune: A Revolution in Democracy. New York: Verso.

Gowan, Peter. 1999. The Global Gamble: Washington's Faustian Bid for World Dominance. London, UK: Verso.

--2003. "The New Liberal Cosmopolitanism" in Debating Cosmopolitics. Ed. Daniele Archibugi. London, UK: Verso.

Habermas, Jürgen. 1979. Communication and the Evolution of Society. Trans. Thomas McCarthy. Boston, MA: Beacon Press.

--1984a. The Theory of Communicative Action Volume One: Reason and the Rationalization of Society. Trans. T. McCarthy. Boston, MA: Beacon Press.

--1984b. The Theory of Communicative Action Volume Two: Lifeworld and System: A Critique of Functionalist Reason. Trans. T. McCarthy. Boston, MA: Beacon Press.

--1990. Moral Consciousness and Communicative Action. Trans. Christian Lenhardt and Shierry Weber Nicholsen. Cambridge, MA: MIT Press.

--1991. "What Does Socialism Mean Today? The Revolutions of Recuperation and the Need for New Thinking" in After the Fall: The Failure of Communism and the Future of Socialism. Ed. Robin Blackburn. New York: Verso.

--1994. Justification and Application: Remarks on Discourse Ethics. Trans. C. Cronin. Cambridge, MA: MIT Press.

--1998. Between Facts and Norms: Contributions to a Discourse Theory of Law and Democracy. Trans. William Rehg. Cambridge, MA: MIT Press. 
Hardt, Michael and Negri, Antonio. 2000. Empire. Cambridge, MA: Harvard University Press.

--2009. Commonwealth. Belknap Press.

--2004. Multitude: War and Democracy in the Age of Empire. New York: Penguin.

--2012. Declaration. Argo Navis.

Harvey, David. 2009. Cosmopolitanism and the Geographies of Freedom (Wellek Library Lectures in Critical Theory). New York: Columbia University Press.

--2011. The Enigma of Capital and the Crises of Capitalism. Oxford: Oxford University Press.

--2013. Rebel Cities: From the Right to the City to the Urban Revolution. New York: Verso.

--2014. Seventeen Contradictions and the End of Capitalism. London: Profile Books.

Hegel, G.W.F. 1977. Phenomenology of Spirit. Trans. A.V. Miller. Oxford: Oxford University Press.

Held, David. 1995. Democracy and the Global Order: From the Modern State to Cosmopolitan Governance. Cambridge: Polity.

--2004. The Global Covenant: The Social Democratic Alternative to the Washington Consensus. Cambridge: Polity.

Held, David and McGrew, Anthony. 2007. Globalization/Anti-Globalization. $2^{\text {nd }}$ ed. Malden, MA: Polity.

Horkheimer, Max and Adorno, Theodor. 2007. Dialectic of Enlightenment: Philosophical Fragments. Stanford, CA: Stanford University Press.

Ingram, James. 2013. Radical Cosmopolitics: The Ethics and Politics of Democratic Universalism. New York: Columbia University Press.

Jacoby, Russell. 1984. Repression of Psychoanalysis: Otto Fenichel and the Political Freudians. New York: Basic Books.

Jameson, Fredric. 1974. Marxism and Form: Twentieth-Century Dialectical Theories of Literature. Princeton, NJ: Princeton University Press. 
--1981. The Political Unconscious: Narrative as a Socially-Symbolic Act. Ithaca, NY: Cornell University Press.

--[1990] 2007. Late Marxism: Adorno or the Persistence of the Dialectic. New York, NY: Verso.

--1996. "Five Theses on Actually Existing Marxism" in Monthly Review. Vol. 47. Iss. 11. https://archive.monthlyreview.org/index. php/mr/article/view/MR-047-111996-04_1

Jonna, R. Jamil and Foster, John Bellamy. 2016. "Marx’s Theory of Working-Class Precariousness

Its Relevance Today" in Monthly Review. Vol. 67. Iss. 11. http://monthlyreview.org/2016/04/01/marxs-theory-of-working-classprecariousness/

Kautsky, Karl. [1919] 1964. The Dictatorship of the Proletariat. Ann Arbor, MI: University of Michigan Press.

Keucheyan, Razmig. [2010] 2013. The Left Hemisphere: Mapping Critical Theory Today. Trans. Gregory Elliot. New York: Verso.

Klein, Naomi. 2014. This Changes Everything: Capitalism vs. the Climate. New York: Simon \& Schuster.

Kolbert, Elizabeth. 2015. The Sixth Extinction: An Unnatural History. New York: Picador.

Konings, Martijn. 2015. The Emotional Logic of Capitalism: What Progressives Have Missed. Stanford, CA: Stanford University Press.

Lukács, Georg. [1968] 1971. History and Class Consciousness: Studies in Marxist Dialectics. Cambridge, MA: The MIT Press.

Laclau, Ernesto and Mouffe, Chantal. 1985. Hegemony and Socialist Strategy: Towards a Radical Democratic Politics. New York: Verso.

Levine, Daniel J. 2012. Recovering International Relations: The Promise of Sustainable Critique. New York: Oxford University Press.

Linklater, Andrew. 1998. The Transformation of Political Community: Ethical Foundations of the Post-Westphalian Era. Columbia, SC: University of South Carolina Press. 
--2011. The Problem of Harm in World Politics: Theoretical Investigations. Cambridge, UK: Cambridge University Press.

Lissagaray, Prosper-Olivier. 2012. The History of the Paris Commune of 1871. New York: Verso.

Löwy, Michael. 2015. Ecosocialism: A Radical Alternative to Capitalist Catastrophe. Chicago, IL: Haymarket.

Luxemburg, Rosa. 2006. Reform of Revolution and Other Writings. Mineola, NY: Dover.

MacLean, Nancy. 2008. Freedom Is Not Enough: The Opening of the American Workplace. Cambridge, MA: Harvard University Press.

Markus, Hasel Rose and Schwartz, Barry. 2010. "Does Choice Mean Freedom and WellBeing?" in The Journal of Consumer Research. Vol. 37. August 2010. Available online at:

http://www.swarthmore.edu/Documents/academics/psychology/Markus\%20\%20Schwartz\%202010\%20Does\%20Choice\%20mean.pdf

Marx, Karl. 1978. "The Economic and Philosophic Manuscripts of 1844" in The MarxEngels Reader. Ed. Robert C. Tucker. $2^{\text {nd }}$ edition. New York: W.W. Norton.

--1978. “The German Ideology” in The Marx-Engels Reader. Ed. Robert C. Tucker. $2^{\text {nd }}$ edition. New York: W.W. Norton.

--1978. "The Grundrisse" in The Marx-Engels Reader. Ed. Robert C. Tucker. $2^{\text {nd }}$ edition. New York: W.W. Norton.

--1978. "Wage, Labour, and Capital" in The Marx-Engels Reader. Ed. Robert C. Tucker. $2^{\text {nd }}$ edition. New York: W.W. Norton.

--1978. “Capital: Volume 1” in The Marx-Engels Reader. Ed. Robert C. Tucker. $2^{\text {nd }}$ edition. New York: W.W. Norton.

Meiksins Wood, Ellen. 1986. The Retreat from Class: A New 'True' Socialism. New York: Verso.

Mészáros, István. 2015. The Necessity of Social Control. New York: Monthly Review Press.

Miéville, China. [2005] 2006. Between Equal Rights: A Marxist Theory of International Law. Chicago, IL: Haymarket Books.

-- 2015 (a) “The Limits of Utopia” in Salvage, \#1. 
--2015(b) “On Social Sadism” in Salvage, \#2.

Milanovic, Branko. 2012. The Haves and the Have-Nots: A Brief and Idiosyncratic History of Global Inequality. New York: Basic Books.

Miliband, Ralph. 2015. Class War Conservatism and Other Essays. New York: Verso. --1977. Marxism and Politics. Oxford, UK: Oxford University Press.

Moore, Jason W. 2015. Capitalism in the Web of Life: Ecology and the Accumulation of Capital. New York: Verso.

Morton, Timothy. 2013. Hyperobjects: Philosophy and Ecology After the End of the World. Minneapolis, MN: University of Minnesota Press.

Mouffe, Chantal. 2000. The Democratic Paradox. New York: Verso.

--2013. Agonistics: Thinking the World Politically. New York: Verso.

Ness, Immanuel. Southern Insurgency: The Coming of the Global Working Class. London: Pluto Books.

Nisen, Max. 2013. "How Nike Solved Its Sweatshop Problem" in Business Insider. May 9, 2013. Available online at: http://www.businessinsider.com/how-nike-solvedits-sweatshop-problem-2013-5

Noys, Benjamin. 2013. "The Grammar of Neoliberalism" in Dark Trajectories: Politics of the Outside. Ed. Joshua Johnson. Hong Kong: [NAME] Publications.

Okin, Susan Moller. 1989. Justice, Gender, and the Family. New York: Basic Books.

Ollman, Bertell. 1971. Alienation: Marx's Conception of Man in Capitalist Society. Cambridge University Press.

Panitch, Leo and Gindin, Sam. 2013. The Making of Global Capitalism: The Political Economy of American Empire. New York: Verso.

Pedroso, Joaquin A. 2015. "The New American Popery" in Dissident Voice. October 7, 2015. Available online at: http://dissidentvoice.org/2015/10/the-new-americanpoperyl

Penketh, Anne. 2014. "France forced to drop 75\% supertax after meagre returns" in The Guardian. December 31, 2014. Available online at: http://www.theguardian.com/world/2014/dec/31/france-drops-75percent-supertax 
Piketty, Thomas. 2014. Capital in the Twenty-Frist Century. Trans. Arthur Goldhammer. Cambridge, MA: Belknap Press.

Pogge, Thomas. 1989. Realizing Rawls. Ithaca, NY: Cornell University Press. --2002. World Poverty and Human Rights. $1^{\text {st }}$ ed. Cambridge: Polity.

Putnam, Robert. 1993. Making Democracy Work: Civic Traditions in Modern Italy. Princeton, NJ: Princeton University Press.

--2001. Bowling Alone: The Collapse and Revival of American Community. New York: Simon and Schuster.

--2004. Better Together: Restoring the American Community. New York: Simon and Schuster.

Rawls, John. 1971. A Theory of Justice. Cambridge, MA: Harvard University Press. --2002. Justice as Fairness: A Restatement. Cambridge, MA: Belknap Press.

Read, Jason. 2015. The Politics of Transindividuality. Historical Materialism Series. Netherlands: Brill.

Reich, Wilhelm. 1970. Character Analysis. New York: Farrar, Strauss, and Giroux. --1980. The Mass Psychology of Fascism. New York: Farrar, Strauss, and Giroux.

Riesman, David. 1950. The Lonely Crowd. New Haven: Yale University Press.

Ritzer, George. 2007. The Globalization of Nothing. $2^{\text {nd }}$ edition. Thousand Oaks, CA: Pine Forge Press.

--2008. The McDonalization of Society, 5. Los Angeles, CA: Pine Forge Press.

Robinson, William. 2004. A Theory of Global Capitalism: Production, Class, and State in a Transnational World. Baltimore, MD: The Johns Hopkins University Press.

Rorty, Richard. 2008 [1996]. "Who Are We? Moral Universalism and Economic Triage." In Global Ethics: Seminal Essays. Ed. Thomas Pogge and Keith Horton. St. Paul, MN: Paragon House.

Rose, Gillian. 2014. The Melancholy Science: An Introduction To The Thought Of Theodor W. Adorno. New York: Verso.

Ross, Kristen. 2016. Communal Luxury: The Political Imaginary of the Paris Commune. New York: Verso. 
Rousseau, Jean-Jacques. 1978. On the Social Contract. Ed. Roger D. Masters. Trans. Judith R. Masters. Boston: Bedford/St. Martins.

Sandel, Michael J. 1982 Liberalism and the Limits of Justice. Cambridge, UK: Cambridge University Press.

Said, Edward. 1994. Culture and Imperialism. New York: Vintage.

Schulte, Elizabeth. 2015. "Hillary Clinton: Capital's Plan A” in Jacobin May 25, 2015. Available online at: https://www.jacobinmag.com/2015/05/hillary-clintonpresident-walmart-business-feminist/

Schumpeter, Joseph. [1919] 2011. Imperialism and Social Classes. Ludwig von Mises Institute.

Scipes, Kim. 2016. "Introduction" and "Multiple Fragments-Strength or Weakness? Theorizing Global Labor Solidarity" in Building Global Labor Solidarity in a Time of Accelerating Globalization ed. Kim Scipes. Chicago, IL: Haymarket.

Schor, Juliet B. 2005. Born to Buy: The Commercialized Child and the New Consumer Culture. New York: Scribner.

Sculos, Bryant William. 2016. "Negative Dialectical Interpretation: Contradiction and Critique" in Interpretation in Political Theory ed. Clement Fatovic and Sean Noah Walsh. New York: Routledge.

--2016. "Review of The Emotional Logic of Capitalism" in Marx \& Philosophy Review of Books ed. Sean Sayers. http://marxandphilosophy.org.uk/reviewofbooks/reviews/2016/2170

Seymour, Richard. 2012. The Liberal Defense of Murder. London, UK:Verso.

--2015. "Our feral, lying, good-for-nothing media" in Salvage. Available online at: http://salvage.zone/online-exclusive/our-feral-lying-good-for-nothing-media/

Shaviro, Steven. 2015. No Speed Limit: Three Essays on Accelerationism. Minneapolis, MN: University of Minnesota Press.

Sheriff, Carol. 1997. The Artificial River: The Erie Canal and the Paradox of Progress, 1817-1862. New York: Hill and Wang.

Smith, John. 2016. Imperialism in the Twenty-First Century: Globalization, SuperExploitation, and Capitalism's Final Crisis. New York: Monthly Review Press. 
Smith, Tony. 2009. Globalization: A Systematic Marxist Account. Chicago, IL: Haymarket Books.

South, James B. and Carveth, Rod. 2010. Mad Men and Philosophy: Nothing Is as It Seems. Hoboken, NJ: Wiley.

Srnicek, Nick. 2016. Platform Capitalism. Cambridge, UK: Polity.

Srnicek, Nick and Williams, Alex. 2013. “\#Accelerate Manifesto for an Accelerationist Politics" in Dark Trajectories: Politics of the Outside. Ed. Joshua Johnson. Hong Kong: [NAME] Publications.

--2015. Inventing the Future: Postcapitalism and a World Without Work. New York: Verso.

Stiglitz, Joseph E. 2014. The Price of Inequality: How Today's Divided Society Endangers Our Future. New York: W.W. Norton.

Therborn, Goran. 2008. From Marxism to Post-Marxism. New York: Verso.

Thompson, E.P. 1966 [1963]. The Making of the English Working Class. Vintage.

Thompson, Michael J. 2015. "Introduction" and "Philosophical Foundations for a Marxian Ethics" in Constructing Marxist Ethics: Critique, Normativity, Praxis ed. Michael J. Thompson. Chicago, IL: Haymarket.

Tocqueville, Alexis de. Democracy in America. Trans./ed./intro. Harvey C. Mansfield and Delba Winthrop. Chicago, IL: Chicago University Press.

Tsipras, Alexis. 2015. "Behind the Compromise" in Jacobin. August 10, 2015. Available online at: https://www.jacobinmag.com/2015/08/greece-memorandum-austeritycoup-tsipras-syriza-interview/

Wallerstein, Immanuel and Balibar, Etienne. Race, Nation, Class: Ambiguous Identities. New York: Verso.

Walker, Rob. 2010. Buying In: What We Buy and Who We Are. New York: Random House.

Warren, Rosie. 2015. “Some Final Words on Pessimism,” in Salvage, \#2.

Watters, Ethan. 2011. Crazy Like Us: The Globalization of the American Psyche. New York: Free Press.

Wilde, Lawrence. 2013. Global Solidarity. Edinburgh: Edinburgh University Press. 
Wilkinson, Richard and Pickett, Kate. 2009. The Spirit Level: Why Greater Equality Makes Societies Stronger. New York: Bloomsbury.

Williamson, Kevin D. 2015. "Bernie's Strange Brew of Nationalism and Socialism" in The National Review. July 20, 2015. Available online at:

http://www.nationalreview.com/article/421369/bernie-sanders-national-socialism

Wolfenstein, E.V. 1993. Psychoanalytic-Marxism: Groundwork. New York: The Guilford Press.

Wolff, Richard Paul. 1977. Understanding Rawls: A Reconstruction and Critique of "A Theory of Justice." Princeton, NJ: Princeton University Press.

Wolin, Sheldon. 2010. Democracy Incorporated: Managed Democracy and the Specter of Inverted Totalitarianism. Princeton, NJ. Princeton University Press.

Wright, Erik Olin. 2010. Envisioning Real Utopias. Verso: New York.

Xenos, Nicholas. 1989. Scarcity and Modernity. New York: Routledge.

Žižek, Slavoj. 1989. The Sublime Object of Ideology. New York: Verso. 
VITA

BRYANT WILLIAM SCULOS

Bscul005@fiu.edu

Master of Arts: Political Science, Florida International University, 2014 (Primary Field: Political Theory, Secondary Field: International Relations) (Distinction in IR)

Bachelor of Arts: Syracuse University, 2011 (Majors: Political Philosophy and U.S. History, Minor: Global Political Economy)

\section{PUBLICATIONS AND PRESENTATIONS}

"Radicalizing Cosmopolitanism: On the Contradictions of Cosmopolitanism and the Necessity of a Socialist Vision." International Studies Association-Northeast Annual Meeting, Providence, RI, Nov. 6-7, 2015.

"Marx in Miami: Reflections on Teaching and the Confrontation with Ideology" with Sean Noah Walsh, in Class, Race and Corporate Power. November 2015. Available at: http://digitalcommons.fiu.edu/cgi/viewcontent.cgi? article=1059\&context=classracecorpo ratepower

"The Poverty of Hatred and the Hatred of Poverty: The Ideology of American Progressivism" in New Politics (online feature). July 9, 2015. Available at:

http://newpol.org/content/poverty-hatred-and-hatred-poverty-ideology-americanprogressivism

"The Marginalization of Democracy and the Fetishization of "the Candidate" in New Politics (online feature). August 4, 2015. Available at:

http://newpol.org/content/resisting-marginalization-democracy-and-fetishization\%E2\%80\%9C-candidate\%E2\%80\%9D

"Demanding a Post-Capitalist Vision: A CriticalTheoretical Intervention between Cosmopolitanism and Marxism.” International Studies Association Annual Meeting, Atlanta, GA, March 16-19, 2016.

"Capital Revenge: Ideologiekritik and The Revenant" in Class, Race and Corporate Power. Vol. 4: Issue 2. May 2016. Available at:

http://digitalcommons.fiu.edu/classracecorporatepower/vol4/iss1/6/ 
"Democracy, Brexit Stage Left: a Socialist Critique of the Brexit Vote," The Hampton Institute, Politics \& Government. July 19, 2016. Available at:

http://www.hamptoninstitution.org/brexit-stage-left.html\#.V46b5_krLcd.

"How is it to be Done?: Cosmopolitanism, Radical Reform, and Post-Capitalism." Western Political Science Association Annual Meeting, San Diego, CA, March 25-26, 2016.

"Epistemological Apathy and Egomania: The Not-so Mysterious Case of Donald J. Trump and the Implications for American Democracy." The Hampton Institute. Politics \& Government. Sept. 29, 2016. Available at: http://www.hamptoninstitution.org/the-notso-mysterious-case-of-donald-trump.html\#.V-zVBvkrLcf.

"Negative Dialectical Interpretation: Contradiction and Critique" in Interpretation in Political Theory ed. Sean Noah Walsh and Clement Fatovic. (New York: Routledge, October 2016), pp. 158-181. See: https://www.routledge.com/Interpretation-in-PoliticalTheory/Fatovic-Walsh/p/book/9781138201668.

"Critical IR Theory and the Need for a Postcapitalist Ethics." International Studies Association-Northeast Annual Meeting, Baltimore, MD, Nov. 4-5, 2016.

"Parenting for Progress: Reflections on Matt Ross's Captain Fantastic," Class, Race and Corporate Power: Vol. 4: Iss. 2, Article 6. Nov. 2016. Available

at: http://digitalcommons.fiu.edu/classracecorporatepower/vol4/iss2/6/

"My Students Are Terrified: Teaching in the Days after Trump," Class, Race and Corporate Power: Vol. 4: Iss. 2, Article 3. Nov. 2016.

Available at: http://digitalcommons.fiu.edu/classracecorporatepower/vol4/iss $2 / 3$ Republished with The Hampton Institute: http://www.hamptoninstitution.org/teaching-inthe-days-of-trump.html

"The Counterrevolutionary Campus: Herbert Marcuse and the Suppression of Student Protest Movements" with Sean Noah Walsh, in New Political Science, Special Issue: "Marcuse in the Twenty-First Century: Radical Politics, Critical Theory, and Revolutionary Praxis" (Vol. 38, Issue 4, December 2016). Available online at: http://www.tandfonline.com/doi/pdf/10.1080/07393148.2016.1228580?needAccess=true

"The Capitalistic Mentality and the Politics of Radical Reform: A (Mostly) Friendly Reply to Michael J. Thompson" (Winter 2017) in New Politics (print feature).

"Repressive Robots and the Radical Possibilities of Emancipated Automation" with Sean Noah Walsh in Political Economy of Robots: Prospects for Prosperity and Peace in the Automated $21^{\text {st }}$ Century, ed. Dr. Ryan Kiggins (Forthcoming, Palgrave 2018). 